Antonio Carlos Chaves Ribeiro

\title{
ELABORAÇÃO E ANÁLISE DO USO DE UM WEBSITE DE APOIO À DISCIPLINA DE LABORATÓRIO DE QUÍMICA ANALÍTICA QUANTITATIVA
}

Dissertação apresentada ao Instituto de Química de São Carlos, da Universidade de São Paulo para a obtenção do título de Mestre em Ciências (Química Analítica).

Orientador (a): Profa. Dra. Salete Linhares Queiroz 


\section{Dedicatória}

Dedico este trabalho aos meus pais Carlos Antonio e Neiva, pelo apoio, amor e carinho que nunca me deixaram faltar, e aos meus irmãos Milton e Cecília, amo todos vocês. 


\section{Agradecimentos}

Aos meus pais por sempre estarem ao meu lado.

À minha orientadora Profa. Dra. Salete Linhares Queiroz.

Aos “irmãos” Luís Alberto, Ana Plepis, Eny, Talhati, Flávio, Irineu e Ângelo. Vocês são parte de mim.

Aos amigos que sempre me escutaram ou que por vezes me fizeram ouvir: Dorival, Paulinho, Simoni, Cassiane, André, Virgína, Glauco, Ézer, Valdir, Ju (Milanez), Cacá, Bibi, Marcelo, Joradana, Lurdinha, Aline, Rodrigo, Rafael, Lidiane, Felipe, Fábio, Thelma, Fabiana, Jú (pinga).

Às amigas da biblioteca, da Seção de Graduação e Pós-Graduação, e dos laboratórios de Ensino.

Ao Instituto de Química de São Carlos, pela infraestruttura e suporte oferecido nestes dois anos de trabalho.

Aos alunos da disciplina Laboratório de Química Analítica Quantitativa (2/2003).

À CAPES, pela bolsa institucional concedida e também pela concessão do auxílio na modalidade "Chamada 1" do Programa de Apoio à Pesquisa em Educação a Distância (PAPED).

À FAPESP pela concessão do auxílio, na modalidade "auxílio à pesquisa" (Processo $\left.n^{0 .} 05 / 56036-7\right)$. 


\section{Epígrafe}

"A arte de viver consiste em tirar o maior bem do maior mal."

Machado de Assis

"Viver muito. Eis a ambição de quase todos. Poucos, porém, têm ambição de viver bem."

John Hughes 


\section{RESUMO}

Embora seja considerável a quantidade de materiais educacionais disponíveis na Internet, poucos são os estudos reportados na literatura que tratam de investigar a efetividade dos mesmos como ferramenta de ensino. Neste trabalho descrevemos a elaboração, uso e avaliação de um sítio produzido como material de apoio para a disciplina de Química Analítica. O sítio foi estruturado disponibilizando aos alunos páginas de conteúdo com descrições textuais dos tópicos discutidos na disciplina, hiperlinks para sítio da Web que oferecem conteúdo relevante ao curso, um fórum eletrônico que permite aos estudantes postarem questões e aos instrutores respondê-las, um glossário, uma sala de bate-papo e uma ferramenta para escrita e envio de relatórios. Participaram, voluntariamente, como sujeitos da pesquisa dois professores de química, um estagiário do Programa de Aperfeiçoamento de Ensino da Universidade de São Paulo e 32 alunos de graduação em química. A navegação de cada um deles no sítio foi monitorada. Dados foram também coletados a partir da realização de entrevistas semi-estruturadas com os professores e da aplicação de questionários aos alunos. Durante o semestre em que foi utilizado pelos alunos da disciplina de Química Analítica, o sítio foi acessado 560 vezes. O sítio foi usado, principalmente, para a escrita e envio de relatório e para consulta às páginas de conteúdo. Poucos alunos fizeram uso do fórum para entrar em contato com os instrutores ou para apresentar questionamentos. $\mathrm{O}$ uso que os estudantes fizeram do sítio sugere que são capazes de utilizar o material suplementar para sanar dúvidas sobre conteúdos específicos. As entrevistas com os professores mostraram que nenhum deles havia utilizado anteriormente a Web como ferramenta de apoio na disciplina de Química Analítica. Os questionários aplicados aos estudantes apontaram para a percepção de que o acesso a materiais educacionais disponibilizados via Web é útil e pode contribuir para o aprendizado dos mesmos. 


\section{ABSTRACT}

Despite the proliferation of educational material on the Internet, few published studies document the strengths and weaknesses of using the World Wide Web as a teaching tool. This work describes the design, use, and evaluation of a site created as a supplement to the Analytical Chemistry course. The site included the following elements: content pages with textual descriptions of the concepts discussed, hyperlinks to Web that provide information about topics in chemistry that are relevant to the course, an eletronic forum that enables students to pose questions and instructors to answer them, glossary, a chatroom and a tool for writing and sending reports. The results presented here will allow us to determine how best to develop other WWW resources and how best to utilize the site discussed here. The research population consisted of two chemistry professors, one teaching assistant and 32 undergraduate chemistry students who voluntarily participated in this research. All navigation for each subject was recorded. Research tools also included semi-structured personal interviews with faculty and teaching assistant, and a student's survey. During the semester of use, the site was accessed 560 times. The site was mainly used for writing and sending reports and reading content pages. Only a few students used the forum to contact instructors and ask them questions. The analysis of student use of the site suggests that they are able to identify the areas that cause them trouble and are able to use supplemental resources to help them in those areas. Interviews with professors indicated that none of them had used the Web as support to the teaching in the Analytical Chemistry course. Analyzing the student's survey, we found that they noted that access to Web-based learning materials was valuable and contributed to their learning as well. 


\section{LISTA DE ILUSTRAÇÕES}

Figura 1: Classificação dos documentos presentes na WWW que servem de apoio ao ensino de química.

Figura 2: Zonas de visualização da página impressa. 1-Zona primária, 2-Zona secundária, 3Zona morta, 4-Zona morta, 5-Centro ótico, 6-Centro geométrico.44 ............................ 21

Figura 3: Página resultante do projeto gráfico apresentando três zonas principais; A barra horizontal no topo da página que contém os links principais, a zona principal de conteúdo e a barra lateral (branca) de menus secundários e textos explicativos.

Figura 4: Modelo de aceitação de tecnologia. Os rótulos indicam os construtos considerados e as setas indicam a influência de um construto em outro.

Figura 5: Construtos utilizados no modelo de aceitação de tecnologia e suas afirmações. As setas representam a influência de um construto em outro e os rótulos periféricos representam os indicadores usados na confirmação do construto.

Figura 6: Diagrama geral para o modelo MVC (modelo-visualização-controle) ${ }^{64}$................... 36

Figura 7: Página de acesso ao sistema, com o formulário de autenticação e link para o cadastro do aluno. Após o login do aluno, são criadas variáveis de sessão (variáveis disponíveis a qualquer momento, enquanto o usuário estiver ativo no sítio), para identificação do usuário, e correspondem ao nome, senha e tipo de usuário.

Figura 8: Página de cadastro no sistema, e formulário de caracterização do aluno, sugerindo um formulário único.

Figura 9: Diagrama esquemático da navegação no sítio para ambos os módulos, administrador e aluno.

Figura 10: Página de Rosto do sistema no módulo administrador. A zona principal da página é a que contém as notícias exibidas no formato data:hora:notícia, em ordem cronológica inversa.

Figura 11: Representação da página de inserção de conteúdo. A caixa de texto principal é na realidade a ferramenta HTMLArea ${ }^{74}$, um código javascript que permite escrever textos formatados diretamente de uma página Web. É interessante notar que a barra lateral exibe os tópicos já adicionados à base para que o administrador não adicione tópicos repetidos ou numeração repetida, fato que anularia toda a operação.

Figura 12: Página de remoção de conteúdo. Os tópicos existentes na base são listados tanto na zona principal quanto na barra lateral do sítio. $\mathrm{O}$ administrador deve selecionar o conteúdo a remover e clicar no botão remover conteúdo no fim da página.

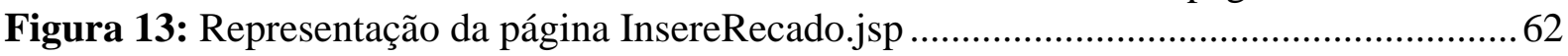

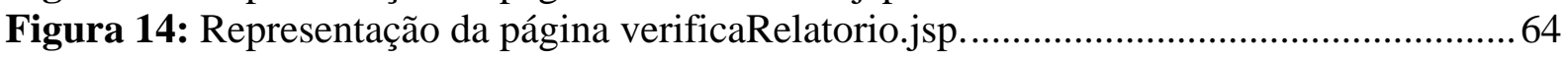

Figura 15: Exemplo de uma das páginas de leitura do sítio...................................................67

Figura 16: Representação da página Envio de Relatório. ……............................................ 72

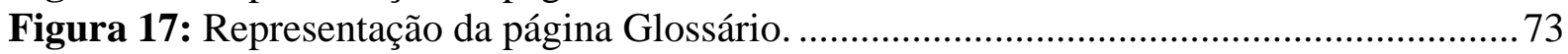

Figura 18: Gráfico de freqüência de respostas dadas a cada categoria estabelecida para as expectativas dos alunos.

Figura 19: Gráfico de acessos totais às páginas mapeadas do sistema. O valor Conteúdo Total reflete a soma dos acessos totais às páginas que compõem o conteúdo teórico (Algarismos Significativos, Análise Gravimétrica e Análise Volumétrica). Glossário, Envio de Relatório, Contato e página de Rosto refletem acessos a páginas individuais.. 91

Figura 20: Gráfico do número de relatórios enviados em relação à prática realizada. $\mathrm{O}$ número 5 no eixo das abscissas representa a prática 5 e o número 11 representa a prática 11. O eixo das ordenadas representa o número total de relatórios enviados para cada uma das práticas.

Figura 21: Representação da página de contato do sistema. 
Figura 22: Acessos totais ao sistema organizado na forma hierárquica do conteúdo. Cada barra vertical corresponde ao numero absoluto de acessos à página em questão. Os tópicos representados que não possuem acessos computados se referem a páginas que não foram acessadas ou não estavam disponíveis aos alunos. O título de cada tópico é reproduzido na Tabela 4. As separações verticais indicam as divisões do conteúdo nas áreas correspondentes.

Figura 23: Diagrama geral da navegação nos conteúdos do sistema. Os círculos numerados em azul representam as áreas disponíveis (como Algarismos Significativos). As caixas nomeadas em verde representam os tópicos oferecidos pela área (como o tópico Sistema Tampão).

Figura 24: Gráfico do número de visitas totais para cada página do sítio construído por Weaver $^{28}$. As barras azuis representam páginas de conteúdo e as barras cinzas representam problemas práticos oferecidos no sistema..

Figura 25: (A) Gráfico da navegação individual para dois alunos que navegam apenas nas páginas: Rosto, Envio de Relatório e Contato - padrão 1. (B) Gráfico da navegação individual para dois alunos que navegam nas páginas acima citadas, no Glossário e nas páginas de conteúdo - padrão 2. O eixo Y representa as páginas disponíveis no sistema. $\mathrm{O}$ eixo $\mathrm{X}$ representa a ordem de acesso pelo estudante.

Figura 26: Gráfico de rede que exibe a navegação individual dos alunos para a página de Rosto, Envio de Relatório, Glossário e Contato, representadas pelos níveis de 1 a 4, respectivamente. As linhas coloridas representam a navegação de cada aluno e iniciam no nível 1 (página de Rosto). Os números em volta do gráfico representam a ordem de acesso (com máximo em 26). Cada ponto representa um acesso à página em questão. 107

Figura 27: Gráfico de acessos totais por período de tempo. O eixo das abscissas exibe intervalos mensais de tempo e a ordenada exibe o número absoluto de acessos.

Figura 28: Gráfico da navegação individual do professor da Turma 1 e estagiário da Turma 2. A barra azul representa a navegação do professor da Turma 1 e a barra magenta a navegação do estagiário da Turma 2. Os pontos coloridos representam cada página acessada. $\mathrm{O}$ eixo Y representa as páginas disponíveis no sistema. O eixo X representa a ordem de acesso pelo professor/estagiário.

Figura 29: Página inicial do fórum de discussão PHPBB2 ............................................... 116

Figura 30: Transcrição da primeira sessão de monitoria via Internet realizada na disciplina.

Figura 31: Índice de respostas em escala Likert de cinco pontos para as quatro afirmações. Cada barra vertical mostra o número de respostas para cada opção em cada uma das afirmações.

Figura 32: Î́ndice de respostas em escala Likert de cinco pontos para as 3 afirmações. Cada barra vertical mostra o número de respostas para cada opção em cada uma das afirmações.

Figura 33: Îndice de respostas em escala Likert de cinco pontos para as 6 afirmações relativas ao construto Utilidade Percebida do $\mathrm{MAT}^{45}$. As barras verticais mostram o número de respostas para cada opção em cada uma das afirmações. As afirmações são reproduzidas no gráfico na ordem em que foram respondidas pelos alunos. Barras que não tenham correspondentes na legenda representam índice 0 de respostas.

Figura 34: Índice de respostas em escala Likert de cinco pontos para as 6 afirmações relativas ao construto Facilidade Percebida do $\mathrm{MAT}^{45}$. Cada barra vertical mostra o número de respostas para cada opção em cada uma das afirmações......

Figura 35: Índice de respostas em escala Likert de cinco pontos para as 4 afirmações relativas ao construto Uso Real do modelo $\mathrm{MAT}^{45}$. Cada barra vertical mostra o número de 
respostas para cada opção em cada uma das afirmações. As afirmações que não encontram correspondentes no gráfico indicam ausência de resposta. 


\section{LISTA DE TABELAS}

Tabela 1: Freqüência e porcentagem de respostas para cada um dos itens do questionário de caracterização do aluno.

Tabela 2: Expectativas iniciais dos alunos no que diz respeito à utilização do sítio. A coluna Respostas lista as respostas dadas à questão dissertativa presente no questionário de caracterização e as colunas Categorias mostram em que categoria cada resposta se encaixa.

Tabela 3: Tabela das práticas executadas durante o semestre.

Tabela 4: Numeração e títulos dos tópicos referentes ao conteúdo teórico oferecido pelo sistema. O número total de acessos a cada tópico pode ser observado na Figura 22 .... 100

Tabela 5: Tipo de acesso às áreas de conteúdo e o número total de alunos que exibiram este comportamento.

Tabela 6: Médias, desvios-padrão e Alfa de Chronbach para itens e construtos do MAT. ... 137 


\section{LISTA DE QUADROS}

Quadro 1: Representação dos 3 construtos analisados e os indicadores sugeridos por Selim ${ }^{45}$.

Quadro 2: Estrutura de diretórios do sítio de Internet que segue o padrão exigido a uma Web Application, contando com a pasta WEB-INF, e as classes organizadas dentro desta

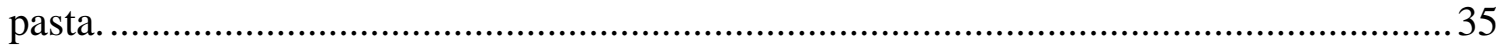

Quadro 3: Sintaxe de um arquivo CSS. São exemplificados os títulos de nível 1 e 2...........41

Quadro 4: Código-fonte do modelo geral para as páginas internas do sítio. ..........................43

Quadro 5: Código-fonte da página loginAction.jsp, que verifica o cadastro do usuário, e redireciona à página de rosto do administrador ou do aluno.

Quadro 6: Código-fonte da página CadastroAlunoAction.jsp, responsável por inserir os dados do usuário nas tabelas ALUNO e USUARIO do sistema.....................................52

Quadro 7: Código-fonte da classe "insere_usuario.class", responsável por inserir os dados do usuário nas tabela USUARIO do sistema. Este código representa o arquivo "insere_usuário.java" na pasta WEB-INF/BD/SRC

Quadro 8: Código-fonte da classe "insere_aluno.class", responsável por inserir os dados do questionário de caracterização na tabela ALUNO do sistema. Este código representa o arquivo "insere_aluno.java" na pasta WEB-INF/BD/SRC.

Quadro 9: Scriptlet usado na página de rosto (em ambos os módulos)................................56

Quadro 10: Código-fonte da classe "seleciona_recados". ..................................................56

Quadro 11: Código-fonte da classe "HtmlTableRecado"....................................................57

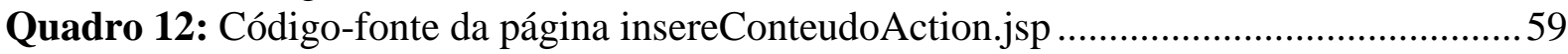

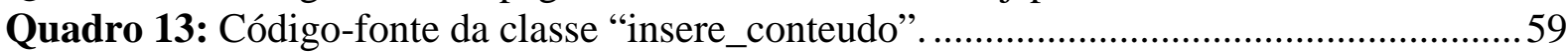

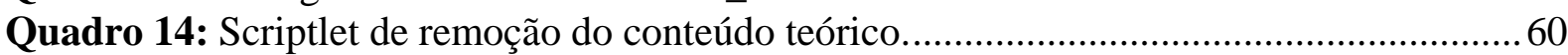

Quadro 15: Código-fonte para a classe "seleciona_conteudo_area.class". ..........................61

Quadro 16: Código-fonte para a classe "HtmlTableRemoveConteudo". .............................62

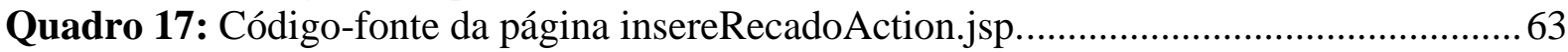

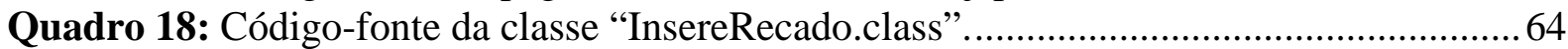

Quadro 19: Scriptlet usado na página verificaRelatorio.jsp. .............................................65

Quadro 20: Classe "seleciona_relatorios". Seleciona da tabela RELATORIO o número da prática, número do aluno, nome, data, hora e turma, de forma a gerar o índice visto na página verificaRelatorio.jsp.....

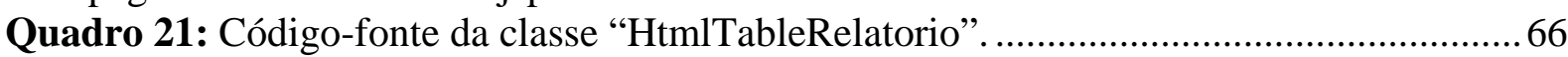

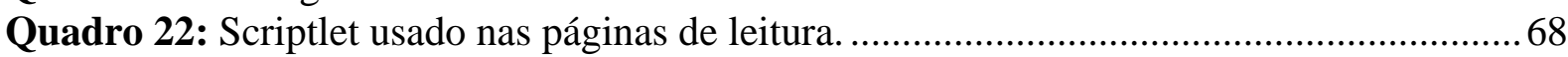

Quadro 23: Código-fonte para a classe "seleciona_conteudo_area". ....................................69

Quadro 24: Código-fonte de classe "HtmlTableConteudo". ................................................... 71

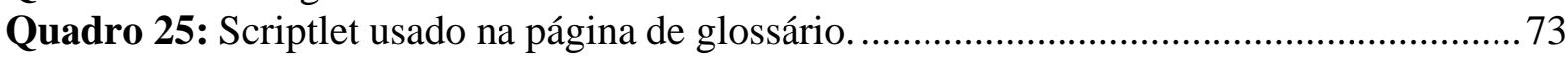

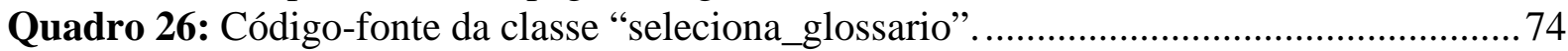

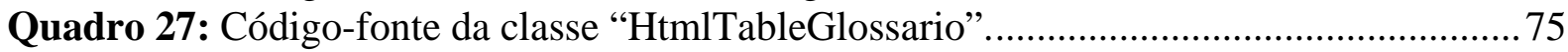

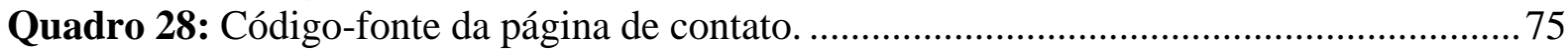

Quadro 29: Código-fonte da ferramenta de inserção de data e hora........................................ 77

Quadro 30: Código-fonte da ferramenta de mapeamento da navegação................................78

Quadro 31: Código-fonte da classe "insere_track".............................................................. 78

Quadro 32: Mensagens enviadas à sala Sugestões do fórum de discussão........................... 117

Quadro 33: Mensagens enviadas à sala Dúvidas Gerais do fórum de discussão................... 118

Quadro 34: Mensagens enviadas à sala Dúvidas Gerais do fórum de discussão................... 120

Quadro 35: Mensagens enviadas à sala da Prática 11, sobre Volumetria de Complexação EDTA, do fórum de discussão. 


\section{SUMÁRIO}

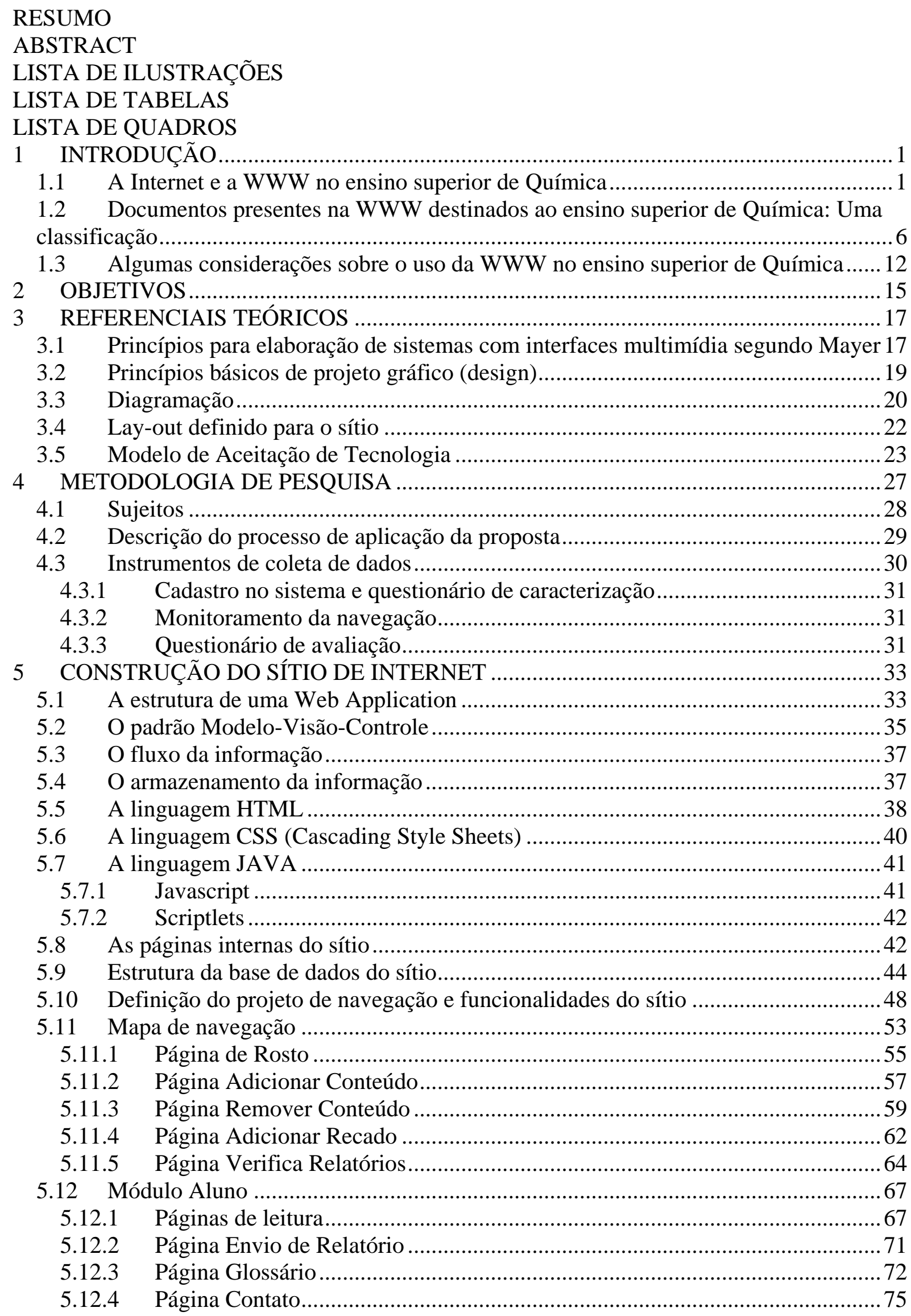




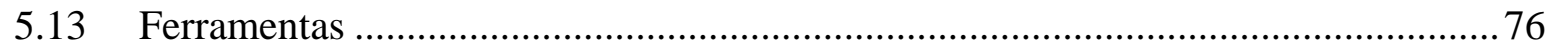

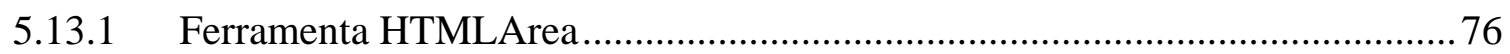

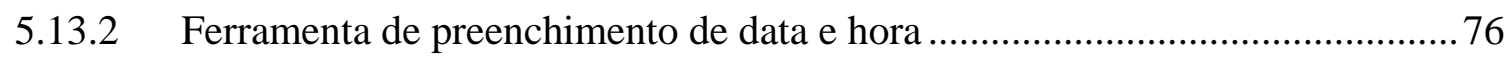

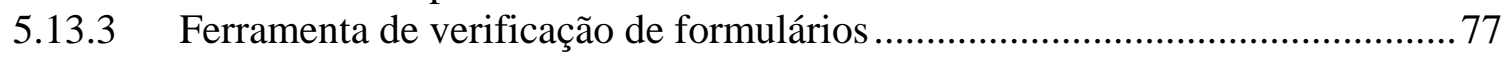

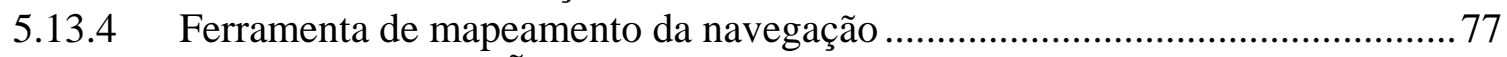

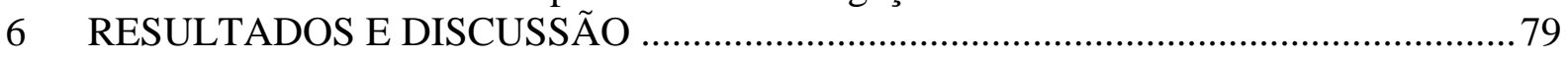

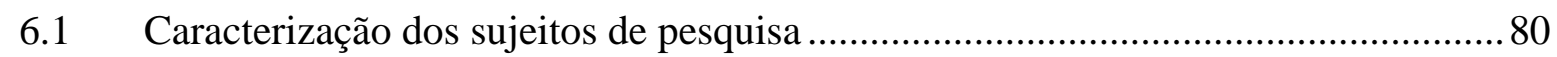

6.2 As expectativas dos alunos no que diz respeito à utilização do sítio ....................... 84

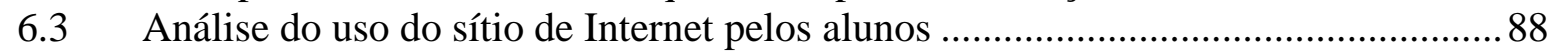

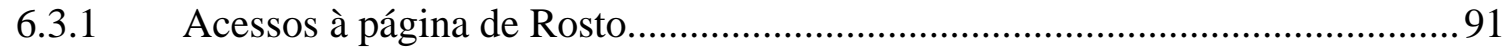

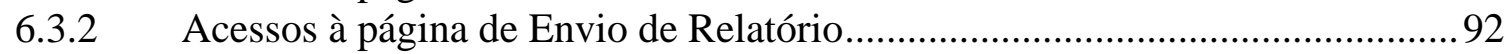

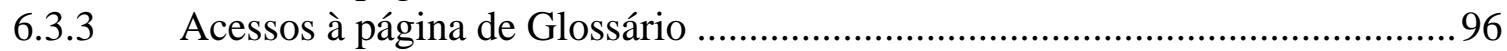

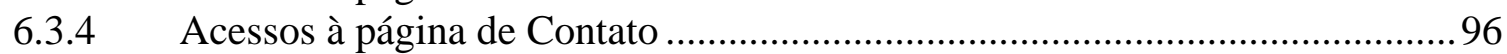

6.3.5 Acessos às páginas de Conteúdo ................................................................ 98

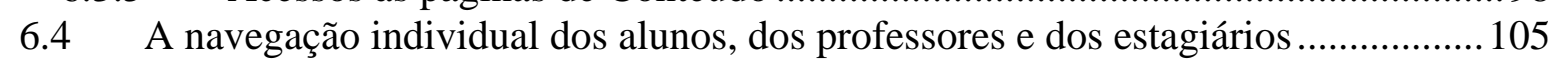

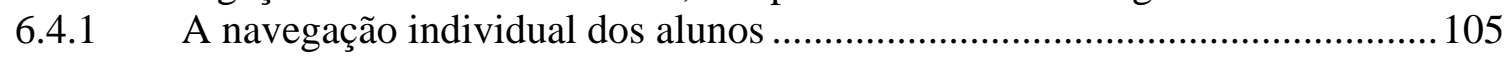

6.4.2 A navegação individual dos professores e estagiários................................... 111

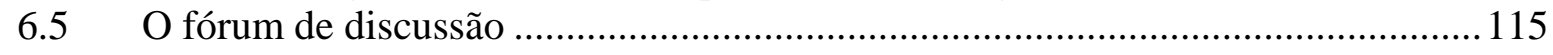

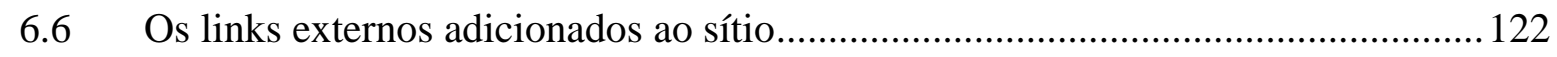

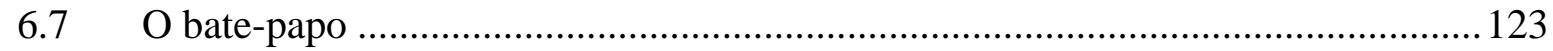

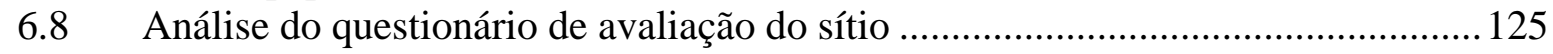

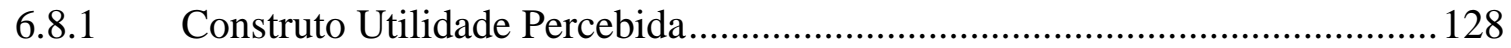

6.8.2 Construto Facilidade Percebida...................................................................... 130

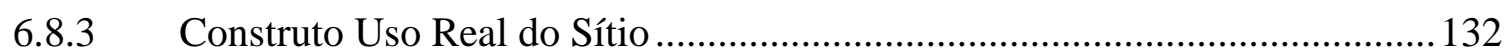

6.9 Afirmações relacionadas ao MAT presentes no questionário de avaliação: resultados preliminares obtidos por análise fatorial ...................................................................... 135

6.10 Sugestões apresentadas pelos alunos para a melhoria do sítio e modificações nele

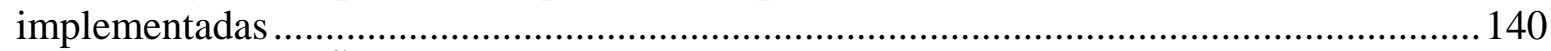

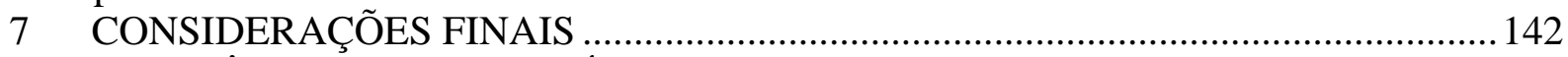

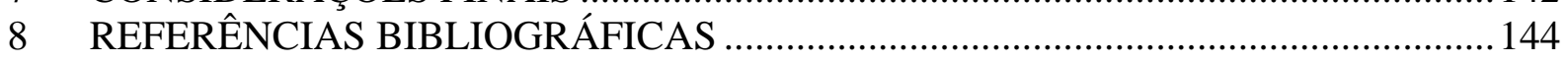

ANEXO A - Busca bibliográfica de Janeiro de 1995 a Julho de 2005 .................................. 151

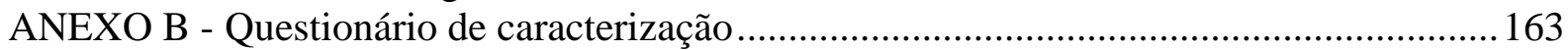

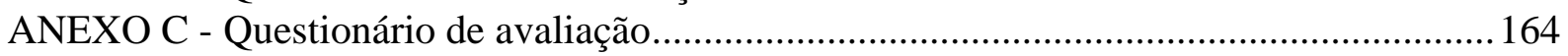

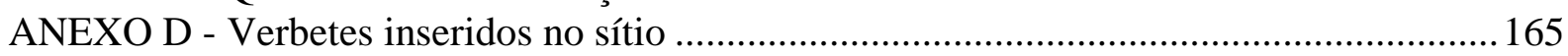

ANEXO E - Links inseridos no sítio ............................................................................... 167

ANEXO F - Navegação individual de cada um dos 17 alunos selecionados ........................ 169 


\section{INTRODUÇÃO}

\subsection{A Internet e a WWW no ensino superior de Química}

A Internet é um meio de comunicação ainda em descoberta que vem gerando mudanças consideráveis nas mais diversas áreas de atividade nos últimos anos, inclusive na área de ensino de química ${ }^{1-3}$. A Internet surgiu a partir de uma rede idealizada em meados dos anos 60, como uma ferramenta de comunicação militar alternativa, na qual cada computador pertencente à rede seria apenas um ponto que, impossibilitado de operar, não interromperia o fluxo das informações ${ }^{4}$. Com base neste conceito, em outubro de 1969, entrou em operação a ARPAnet (Advanced Research Projects Agency Network) primeiro nome dado à Internet.

No início dos anos 80, com o desenvolvimento e utilização do protocolo TCP/IP (Transmission Control Protocol/Internet Protocol) para a troca de informações na ARPAnet, possibilitou-se a conexão entre redes diferentes, aumentando bastante a sua abrangência. Em 1990, a ARPAnet foi transformada em NSFnet (National Science Foundation's Network), que se ligou a outras redes existentes, inclusive fora dos Estados Unidos, passando a interconectar centros de pesquisa e universidades em todo o mundo. Estava formada a Internet, utilizada principalmente como ferramenta de troca de informações no meio acadêmico.

No Brasil, as primeiras iniciativas no sentido de disponibilizar a Internet ao público em geral foram tomadas em 1995, com a atuação dos Ministérios da Comunicação e de Ciência e Tecnologia, no sentido de implantar a infraestrutura necessária e definir parâmetros para a posterior operação de empresas privadas provedoras de acesso aos usuários ${ }^{4}$. 
A Internet é estruturada de forma a permitir que computadores, em espaços físicos diferentes, a partir de um protocolo de comunicação comum, compartilhem informações das mais diversas formas, sejam elas textuais, pictóricas ou sonoras. Cabe aqui relembrar que a Internet e a WWW (World Wide Web, ou simplesmente Web) não são sinônimos, embora freqüentemente estes termos sejam utilizados como tal. Na realidade, a WWW é um espaço que permite a troca de informações multimídia (texto, som, gráficos e vídeo) através da estrutura da Internet ${ }^{4}$. É apenas uma das formas de utilização da Rede, assim como o e-mail (correio eletrônico), o FTP (File Transfer Protocol) ou outros menos conhecidos atualmente ${ }^{4}$.

Desenvolvida no início da década de 1990 pelo cientista inglês Tim Berners-Lee nos laboratórios do CERN (Conseil Européen pour la Recherche Nucléaire), na Suíça, a World Wide Web nasceu da necessidade de compartilhar dados entre os membros dos diversos projetos de pesquisa em andamento no CERN. Ela foi concebida como uma ferramenta alternativa de troca de informações mais amigável que as interfaces "somente-texto" utilizadas até então. Tim Berners-Lee desenvolveu uma linguagem de programação chamada HTML (HyperText Markup Language) que permitia ao usuário explorar os documentos compartilhados na Rede, utilizando um mouse e um software navegador (browser), desenvolvido especialmente para esta finalidade. A linguagem HTML permite acessar diversas informações de modo não-linear, ou seja, no qual o usuário não tem o compromisso de seguir a ordem "começo, meio e fim", podendo traçar a sua ordem particular, "navegando" através de um documento (composto de texto, imagem ou som) a outro através de ligações entre eles (links), mesmo que armazenados em computadores remotos. A primeira demonstração pública da WWW foi realizada em dezembro de 1990. Em maio de 1991 ela foi implementada nos computadores do CERN. 
Percebendo o potencial de sua invenção, uma forma simples e eficiente de trocar e acessar diferentes tipos de dados entre computadores e redes diversas, Tim Berners-Lee a manteve disponível para todos. Assim que os primeiros navegadores foram desenvolvidos para os sistemas operacionais mais comuns (Windows e Macintosh), a WWW foi imediatamente adotada pela comunidade da Internet, sendo responsável - juntamente com a disseminação dos computadores pessoais - pelo grande crescimento da Internet, verificado na década de $1990^{4}$.

O número crescente de trabalhos reportados na literatura especializada sobre o uso da Internet e da WWW na promoção do ensino à distância ${ }^{1,5}$ ou no apoio ao ensino tradicional de química ${ }^{6,7}$ permite vislumbrar o papel que vêm desempenhando como agentes modificadores deste ensino.

Os primeiros trabalhos reportados na literatura sobre a utilização da Internet no ensino de química aparecem por volta de 1995. Os artigos "Teaching online data systems to graduate students of toxicology", de Thomson e colaboradores ${ }^{8}$, e "Using Internet to disseminate an expert system of chemical information resources", de Carande e Harkanyi ${ }^{9}$, foram os primeiros a surgir, no ano de 1995, na renomada revista da área de ensino de química, Journal of Chemical Education. O trabalho de Thomson e colaboradores ${ }^{8}$ trata de um curso de toxicologia destinado ao treinamento de alunos de mestrado e doutorado para buscas em bases de dados disponíveis na Internet. Neste trabalho os autores atentam para a importância do desenvolvimento pelo estudante de habilidades de busca, avaliação e interpretação de informações e concluem que estudantes com habilidades de busca on-line tornam-se usuários efetivos em "um mundo onde o desafio não é mais encontrar informação e sim o que fazer com todas as informações obtidas". O trabalho de Carande e Harkanyi ${ }^{9}$ trata de uma ferramenta de referência escrita em PROLOG e disponibilizada via FTP pela San 
Diego State University Library, denominada ChemRAS (Chemistry Reference Advisory System), com potencialidade para responder aos seus usuários um número limitado de questões acerca da identificação e nomenclatura de compostos químicos, bem como sobre dados espectrais.

Os primeiros trabalhos publicados na literatura sobre a utilização da WWW no ensino de química surgem também nos anos noventa. Em 1996, por exemplo, foram publicados artigos como "Applying hypermedia to chemical education"" e "Design and student use of World Wide Web-based prelab exercises"11. No primeiro, Tissue $^{10}$ enfatiza a importância tanto da utilização de material hipermídia no ensino, quanto da adequação de material convencional (notas de aula, livros texto, etc) ao formato da WWW. No segundo, em parceria com outros autores, ele descreve e analisa a utilização por estudantes de graduação de exercícios pré-laboratório, disponíveis na Web, vinculados a um projeto denominado "Chemistry hypermedia project". O projeto consistiu de tutoriais hipermídia associados a questões de múltipla escolha sobre o tema "Análise Instrumental”. A intenção dos autores na elaboração do projeto foi de substituir demoradas sessões de leitura em sala-de-aula por exercícios interativos a fim de familiarizar os estudantes com os experimentos de laboratório e a instrumentação necessária para suas execuções.

No primeiro trabalho, Tissue ${ }^{10}$ ressalta que o emprego de material hipermídia pode vir a amenizar alguns problemas existentes no ensino de química e cita como exemplo o fato dos estudantes freqüentemente não estabelecerem conexões entre os tópicos que estudam em um determinado semestre e os estudados em semestres anteriores, mesmo que conceitos relevantes tenham sido compreendidos. O autor acredita que a apresentação do conteúdo de química no formato da WWW, no qual o estudante decide ativamente o caminho a seguir (leitura em formato não-linear) e o conteúdo a ser absorvido, pode favorecer o 
estabelecimento de conexões entre os tópicos ministrados em momentos distintos do curso de graduação. No segundo trabalho, Tissue e colaboradores ${ }^{11}$, a partir da análise da utilização dos exercícios pré-laboratório disponíveis na Web, concluem que esta pode ser convenientemente empregada para disponibilizar material didático aos estudantes.

Mounts $^{12}$, também em 1996, publicou o trabalho "Chemistry on the Web" com o intuito de mostrar à comunidade científica, vantagens e desvantagens do uso da Web no ensino de química, assim como detalhamentos no que se refere à sua implementação por instituições de ensino e pesquisa. Mounts ${ }^{12}$ descreve também a utilização do Chemical MIME, uma linguagem que permite a inserção e transferência de estruturas moleculares via páginas HTML. Para visualização destas estruturas, o autor sugere o software RASMol que, instalado junto a um navegador, permite um controle sofisticado e interativo destas estruturas.

Do início dos anos noventa até então muitos outros artigos que tratam da utilização da WWW para fins educacionais foram publicados em revistas dedicadas à área de ensino de química. O trabalho de Bock e colaboradores ${ }^{13}$, por exemplo, apresenta o sistema CIRRUS, "The chemistry Internet resource for research by undergraduate students", que visa disponibilizar informações e estabelecer um senso de comunidade entre graduandos e envolvidos na pesquisa em química e áreas correlatas. Em outra perspectiva, Yates ${ }^{14}$ relata no artigo "World Wide Web publishing as a basis for students projects", uma experiência ocorrida na University of Keele, Reino Unido, na qual os estudantes de graduação projetaram material educacional para Web em linguagem HTML.

Com o acelerado desenvolvimento de novas tecnologias têm sido reportados trabalhos com usos cada vez mais elaborados da Web no ensino. O artigo "Remote instrumentation for the teaching laboratory" exemplifica bem este nível de sofisticação. Neste caso, Kennepohl e colaboradores ${ }^{15}$ combinam softwares de acesso remoto e aquisição de 
dados em uma interface para Web com o intuito de ministrar aulas de análise instrumental a estudantes distantes geograficamente da universidade. Aos estudantes é permitido controlar fisicamente a instrumentação de aula em horários pré-determinados e analisar os dados obtidos na universidade ou à distância. O estudo, aplicado a diversos métodos instrumentais, mostra a importância de uma interface amigável entre o aluno e o computador visto que o controle de softwares de instrumentação de análise, por alunos de graduação em química não é trivial.

\subsection{Documentos presentes na WWW destinados ao ensino superior de Química: Uma classificação}

A partir dos exemplos citados acima, pode-se perceber a imensa gama de possibilidades para o uso da Web no ensino de química. Considerando o conjunto de informações apresentadas em artigos publicados nas revistas Journal of Chemical Education e The Chemical Educator, no intervalo de 1995 a Julho de 2005, nos propomos a apresentar aqui uma classificação dos documentos destinados a este ensino presentes na WWW. Os artigos presentes nas referidas revistas, no intervalo de tempo citado, foram reunidos em uma lista reproduzida no Anexo A e ilustram a evolução dos trabalhos destinados a este ensino. A Figura 1 sintetiza nossa classificação, cujo princípio organizador considera a intenção de acesso do usuário ao documento. É importante salientar que um Website (sítio) dificilmente pode ser inserido em apenas uma classe.

A Figura 1 mostra duas categorias principais de documentos presentes na WWW que podem servir de apoio ao ensino de química. A primeira categoria diz respeito a documentos que oferecem Serviços de Consulta, com preenchimento e envio de formulários, enquanto a segunda está relacionada a documentos que oferecem Conteúdos, textual pictórico ou sonoro. 
Ambas encontram-se subdivididas de tal forma que a primeira categoria abarca documentos que permitem o acesso à Base de Dados, a Referências Bibliográficas e também que proporcionam alguma forma de Atendimento ao Estudante, através da resolução de dúvidas. A segunda categoria encontra-se subdividida de acordo com a forma como o conteúdo é disponibilizado ao estudante, se na forma Estática ou Dinâmica. Entenda-se por conteúdo estático aquele apresentado diretamente na página HTML, e que não é modificado a cada requisição do usuário, e por conteúdo dinâmico aquele que é armazenado separadamente do código, onde a cada requisição do usuário a página HTML é reconstruída de forma a exibir o conteúdo apropriado $^{16}$.

\begin{tabular}{|c|c|c|c|c|}
\hline \multirow{12}{*}{ 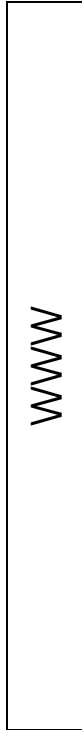 } & \multirow{3}{*}{ 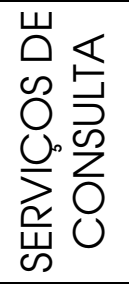 } & \multicolumn{3}{|c|}{ Bases de dados } \\
\hline & & \multicolumn{3}{|c|}{ Bibliotecas de referência } \\
\hline & & \multicolumn{3}{|c|}{ Atendimento aos estudantes } \\
\hline & & & Tutoriais & \\
\hline & & ESTÁTICO & Salas de lei & \\
\hline & O & & Listas e Ex & \\
\hline & $\supseteqq$ & & Colaboraçã & \\
\hline & $\ddot{\rightleftarrows}$ & & Jogos & \\
\hline & $\mathrm{Z}$ & DINÂAMICO & Acesso rem & \\
\hline & $U$ & DIIVAIVICU & & Cálculos \\
\hline & & & Simulação & Modelagem \\
\hline & & & & Experimentos \\
\hline
\end{tabular}

Figura 1: Classificação dos documentos presentes na WWW que servem de apoio ao ensino de química.

Entre os documentos que oferecem Serviços encontram-se aqueles que permitem o acesso a Bases de Dados contendo propriedades periódicas dos elementos e informações sobre compostos químicos, podendo-se citar como exemplo o Webelements ${ }^{17}$, que pode ser utilizado para resolução de problemas, conforme sugere Murov ${ }^{18}$ e o WebSpectra ${ }^{19}$, citado no trabalho de Merlic e colaboradores ${ }^{20}$, que permite o acesso livre a espectros de RMN e IR de vários compostos. Os documentos que possibilitam a consulta a Bibliotecas de Referência são 
também classificados entre aqueles que podem auxiliar o ensino de química. No caso do Brasil, são englobados por esta classe sítios como Periódicos $\mathrm{CAPES}^{21}$, o SciELO-Brasil ${ }^{22}$, o SiBINET $^{23}$ e o ProBE $^{24}$, que permitem busca e acesso a artigos em diversas publicações seriadas.

Os documentos que oferecem serviços de Atendimento aos Estudantes, são aqueles que, via formulário, permitem a interação com tutores, seja na resolução de dúvidas ou na busca de informações pertinentes ao tópico em estudo. Esta classe pode ainda ser subdividida, segundo Giordan e Mello ${ }^{25}$, em: Direcionadores - documentos que não possuem atendimento próprio e se limitam a anunciar algum serviço ou direcionar ao documento correto; Tiradúvidas - que respondem diretamente a dúvida do estudante sem estabelecer relação contínua de diálogo e Orientadores - que não respondem diretamente a dúvida, mas oferecem caminhos para que o aluno desenvolva sua própria resposta. Apenas a modalidade Tiradúvidas foi encontrada nos artigos voltados para o ensino superior de química, por nós considerados para a classificação apresentada na Figura 1. No caso do trabalho reportado por Dori e Barak $^{26}$, o sítio descrito disponibilizava um fórum eletrônico que permitia aos estudantes o envio de dúvidas e posterior apresentação de resolução pelos instrutores. No caso do trabalho de Tissue e colaboradores ${ }^{11}$, o módulo pergunta-e-resposta, inserido na modalidade Tira-dúvidas, se mostrou pouco eficaz já que o serviço foi disponibilizado em uma disciplina de laboratório, na qual as possibilidades de interação entre estudantes, monitores e professores eram significativas, não despertando o interesse ou a necessidade de interação via computador.

Com relação aos documentos que oferecem Conteúdo Estático, destacam-se os que exibem informação sobre um determinado assunto em uma sequiência pré-definida de passos, eventualmente com questões a serem respondidas para o acesso ao passo seguinte; esses 
documentos são classificados como Tutoriais, podendo-se citar o trabalho de Orvis e Koehler $^{27}$ como exemplo. Este conteúdo, destinado à disciplina Laboratório de Química Geral da Georgia Southern University, exibe tutoriais pré-laboratório, amplamente ilustrados, como forma de transmitir ao estudante uma visão clara de todo o processo que deve ser seguido durante o experimento. Aos estudantes é ainda permitido o acesso aos tutoriais durante a prática, visando assim diminuir a possibilidade de erros relacionados ao procedimento. Ainda na classe de conteúdo estático tutorial pode-se mencionar o trabalho de Gervay e Parrill ${ }^{2}$ que cita três tutoriais para o ensino de estereoquímica orgânica, desenvolvidos com o intuito de enriquecer a percepção espacial do aluno.

As Salas de leitura, que também pertencem à classe de conteúdo estático, caracterizam-se por não possuir uma navegação pré-definida, ou seja, permitem a escolha da ordem de exibição do material a ser estudado. Nesta subdivisão, destacamos o trabalho de Weaver $^{28}$, aplicado por dois anos consecutivos na disciplina de Química Geral, na Universidade do Colorado, no qual tecnologias de hipermídia foram utilizadas para desenvolver um sítio acerca do tema ácidos e bases, como material suplementar para a referida disciplina. Outro exemplo importante nesta classe é o sítio Natural Science Pages, criado por Anthony Carpi $^{29}$ e utilizado na disciplina de Introdução da Ciência na Sociedade. Neste sítio o autor disponibiliza aos alunos dois módulos; o primeiro exibe informações sobre a disciplina, glossário, formas de contato com o professor, informações de laboratório e notas dos alunos. O segundo módulo - chamado lições, que podem ser acessadas em qualquer ordem - exibe textos explicativos sobre conceitos fundamentais em ciência, links relevantes externos ao sítio, além de 20 animações que vão desde a Teoria do Orbital Molecular à síntese de proteínas. 
Dentro da classificação por nós elaborada, documentos de Listas e exercícios são aqueles que disponibilizam listas de exercícios, questões e avaliações para exibição e impressão. Na descrição feita por Cruickshank e colaboradores ${ }^{30}$ sobre os benefícios observados a partir da aplicação de recursos disponíveis na Internet no curso de Química Ambiental na Northern Arizona University, destaca-se a importância deste tipo de sítio, uma vez que os estudantes reconhecem o acesso às tarefas e exames de anos anteriores como uma das possíveis formas de melhorar a sua performance durante o curso.

Com relação aos documentos que oferecem Conteúdo Dinâmico, destacam-se aqueles que se concentram nas possibilidades de Colaboração entre envolvidos no processo educacional, na utilização de Jogos, no Acesso Remoto a outros computadores e também na utilização de Simulações.

Sítios que possibilitam o estabelecimento de relações entre alunos e professores, visando uma comunicação mais efetiva entre os mesmos durante um determinado curso, são mencionados com freqüência na literatura ${ }^{31}$. Como exemplo podemos citar o trabalho de Glaser e Poole ${ }^{32}$, sobre a criação de um sítio de Internet que aborda tópicos de química orgânica com o intuito de provocar questionamentos entre os estudantes. Estes questionamentos são enviados para uma lista de discussão on-line, a partir da qual a comunicação entre os envolvidos pode ser incrementada. No entanto, os autores constatam que os estudantes fazem uso apenas esporádico do e-mail, ferramenta utilizada em listas de discussão, e não atentam para sua importância como ferramenta de suporte à disciplina.

Ainda na classe de conteúdo dinâmico podemos citar a subdivisão Jogos na qual se encontram englobados os documentos que disponibilizam jogos que podem ser utilizados como um recurso para o ensino de química ${ }^{33}$. Esta subdivisão pode ser representada pelo 
documento "The Chemical Name Game"34, desenvolvido com o objetivo de facilitar o aprendizado da nomenclatura e de algumas propriedades de espécies químicas.

Os chamados "quizzes", atividades de perguntas e repostas no qual a cada resposta correta o estudante acumula nota para o curso e avança à próxima questão, também estão incluídos nesta classe. Um exemplo importante é o trabalho de Frasier e colaboradores ${ }^{35}$. Neste trabalho, os autores desenvolvem um sítio composto de tutoriais e "quizzes" para serem utilizados como tarefa de casa. O sítio, aplicado a alunos do primeiro ano de graduação em química, exibe aleatoriamente questões a serem respondidas. A cada resposta um registro é gravado e o aluno recebe automaticamente a resposta correta. Os registros gravados permitem acompanhar a evolução do aluno durante o curso e ainda podem servir para direcionar assistência individual aos alunos com maiores problemas. Os autores percebem que os estudantes, voluntariamente, respondem mais "quizzes" do que o exigido e concluem pelo valor do sítio como ferramenta eficiente de apoio ao ensino.

Com relação aos documentos de conteúdo dinâmico na classe Acesso Remoto, apenas um trabalho foi encontrado na literatura. No entanto, frente à sua importância no que se refere ao uso de tecnologias Web no ensino de química, optamos por incluí-lo em nossa classificação. O exemplo desta classe é o trabalho, citado anteriormente, "Remote instrumentation for the teaching laboratory", de Kennepohl e colaboradores ${ }^{15}$.

Os documentos de conteúdo dinâmico, encontrados na literatura, que permitem a Simulação de processos e sistemas, são os que proporcionam a execução de Cálculos Químicos, Modelagem Molecular e de Experimentos de Laboratório. Como exemplo de simulação de Cálculos Químicos, podemos citar o documento "Hückel determinant solver"36 que permite o cálculo de diagramas de energia para sistemas moleculares simples de Hückel a partir de variáveis fornecidas pelo aluno e o "Principal species and $\mathrm{pH}$ in acid-base 
solutions" ${ }^{37}$ que permite determinar as concentrações das principais espécies em uma mistura de soluções.

Como exemplo de documentos que permitem a Modelagem Molecular podemos citar o editor Mol4D, que no trabalho de Bokent e colaboradores ${ }^{38}$ assume o papel de uma importante interface educacional à medida que permite ao estudante construir moléculas orgânicas e obter dados como distância de ligação, ângulos de torção, calor de formação, entre outros.

Entre os documentos que permitem a Simulação de experimentos de laboratório destacamos o sítio Chemcollective ${ }^{39}$, que disponibiliza um applet JAVA no qual o aluno pode realizar diversos experimentos virtuais a partir de vidrarias e reagentes disponíveis.

\subsection{Algumas considerações sobre o uso da WWW no ensino superior de Química}

O uso da WWW no ensino superior de química, como se pode julgar tomando por base a introdução apresentada sobre o assunto, vem crescendo nos últimos anos. Seguramente, o emprego de vários dos recursos que ela disponibiliza podem vir a servir de paliativo para situações preocupantes que vicejam em alguns departamentos e institutos de química espalhados pelo mundo inteiro. Como é sabido, em muitos deles existe um acréscimo na quantidade de aulas que devem ser ministradas e no número de alunos que precisam ser atendidos, com concomitante "encolhimento" do corpo docente. Ademais, os gastos consideráveis com aulas de laboratório e os conhecimentos e experiências distintas dos alunos ingressantes sobre os princípios básicos da ciência a ser ensinada, são também motivo de preocupação constante ${ }^{18}$. 
A literatura nos indica exemplos de experiências realizadas no âmbito do ensino superior de química que se mostraram capazes de amenizar alguns dos problemas acima citados e também de promover, entre outras vantagens, uma aprendizagem mais efetiva dos assuntos ministrados nas aulas ${ }^{29,30}$. Vale salientar o papel relevante que ocupam, entre os casos reportados na literatura, as atividades que se baseiam na utilização de conteúdos dinâmicos, de acordo com a classificação apresentada na Figura 1.

Conforme assinalam Paulisse e Polik ${ }^{40}$, embora grande parte dos documentos disponibilizados para o ensino de química na Web, ofereçam apenas conteúdos estáticos e se constituam em importante repositórios de informações, oferecem poucas vantagens pedagógicas frente aos recursos tradicionais baseados nos documentos impressos. Na verdade, tem sido através do estabelecimento de colaborações entre os envolvidos no processo educacional $^{31,32}$, através das simulações de $\operatorname{experimentos}^{39}$ e da utilização de jogos, proporcionadas via Web, que os resultados mais frutíferos vêm sendo alcançados. Diante dessa constatação, e da observação de que na maioria das instituições de ensino superior em química no Brasil as possibilidades de ensino, oferecidas via Web, se restringem a disponibilização de documentos estáticos, acreditamos que o desenvolvimento de sítios de Internet na área de química que permitam aos estudantes, além do acesso a informações sobre conteúdos, a participação em grupos de discussão sobre tópicos em estudo e de troca de informações sobre os eventos de importância para o aprendizado vivenciados nas aulas, seja oportuno e capaz de conduzir a resultados que possibilitem uma discussão relevante sobre o papel que este tipo de ferramenta pode desempenhar no ensino desta disciplina.

Nesta perspectiva, e com o intuito de fornecer subsídios para que esta discussão progrida, desenvolvemos durante a realização deste trabalho um sítio de Internet, com conteúdos estáticos e dinâmicos, que serviu de apoio às atividades realizadas na disciplina 
Laboratório de Química Analítica Quantitativa, ministrada no curso de Bacharelado em Química do Instituto de Química de São Carlos, e analisamos seu uso pelos estudantes nela matriculados. 


\section{OBJETIVOS}

O uso de computadores na educação em química vem se consolidando nos últimos dez anos. Esta consolidação deve-se, pelo menos em parte, ao advento da WWW. Embora sejam numerosos os documentos destinados ao ensino de química que são facilmente aí acessados, existem ainda poucos trabalhos reportados na literatura que tratam de avaliar a potencialidade de alguns dos recursos disponíveis na $\mathrm{WWW}^{28,29}$.

Neste trabalho temos como objetivo desenvolver um sítio de Internet que sirva de apoio às atividades realizadas na disciplina Laboratório de Química Analítica Quantitativa, ministrada no curso de Bacharelado em Química do Instituto de Química de São Carlos, e avaliar a sua utilização e aceitação pelos estudantes nela matriculados no segundo semestre de 2004. Entendemos a análise do uso do sítio de Internet pelos alunos como de primordial importância para que possamos especular sobre a sua eficácia como facilitador do ensino e para que possamos também vislumbrar suas limitações.

A construção do sítio de Internet pautou-se no trabalho de Richard Mayer ${ }^{41}$, que apresenta princípios para elaboração de sistemas com interface multimídia, e em fundamentos básicos de projeto gráfico ${ }^{42,43}$. A utilização que os alunos fizeram do sítio foi acompanhada através de uma ferramenta de monitoramento de navegação nele inserida e as percepções dos alunos a respeito do conteúdo, utilidade do sítio e uso real foram analisadas a partir da aplicação de um questionário contendo uma questão aberta e 23 afirmações. Foi usada uma escala de resposta tipo Likert, cinco pontos variando entre "Concordo Fortemente" e "Discordo Fortemente". 
Parte das afirmações foi elaborada tomando por base o Modelo de Aceitação da Tecnologia $(\mathrm{MAT})^{45}$.O trabalho de Mayer $^{41}$ e o modelo MAT $^{45}$ encontram-se descritos no capítulo Referenciais Teóricos desta dissertação. 


\section{REFERENCIAIS TEÓRICOS}

Para a construção do sítio de Internet foram consideradas recomendações presentes no trabalho de Richard Mayer ${ }^{41}$, que apresenta princípios para elaboração de sistemas com interface multimídia, e ainda fundamentos básicos de projeto gráfico ${ }^{42,43}$ e diagramação ${ }^{44}$. A aceitação do sítio pelos alunos foi avaliada através da aplicação de um questionário baseado no modelo $\mathrm{MAT}^{45}$.

\subsection{Princípios para elaboração de sistemas com interfaces multimídia segundo Mayer}

Em artigo recentemente publicado na revista New Directions for Teaching and Learning, intitulado "Cognitive theory and the design of multimedia instruction: an example of the two-way street between cognition and instruction", Richard Mayer ${ }^{41}$ apresentou resultados alcançados em suas pesquisas sobre a produção e avaliação de material didático com interface multimídia destinados à explanação de sistemas físicos, mecânicos e biológicos e sugeriu princípios para elaboração de tal material. Para a elaboração destes princípios Mayer $^{41}$ considerou os seguintes pressupostos, oriundos de Teorias Cognitivas ${ }^{46}$, sobre a forma como os indivíduos aprendem a partir de palavras e imagens. Estes pressupostos compreendem:

CANAL DUPLO: o sistema cognitivo humano é formado por dois canais distintos que permitem a representação e manipulação do conhecimento: o audio-verbal e o visual-pictórico. O primeiro processa representações verbais (que chegam ao sistema cognitivo através da audição) e o segundo representações pictóricas (que chegam ao sistema cognitivo através da visão) $)^{47}$. 
CAPACIDADE LIMITADA: a memória é o componente do sistema cognitivo humano que manipula representações verbais e pictóricas nos canais audio-verbal e visual-pictórico. Deve-se considerar que a memória possui uma capacidade limitada para estas manipulações ${ }^{48}$. Assim, o canal visual-pictórico pode ser sobrecarregado se muitas figuras (ou outros materiais visuais) são apresentadas ao mesmo tempo. De forma similar, o canal audio-verbal pode ser sobrecarregado se um grande número de palavras faladas, ou outros sons são apresentados ao mesmo tempo. A sobrecarga de um dos canais pode limitar a habilidade de processamento do outro.

PROCESSAMENTO ATIVO: o processamento ativo nos canais audio-verbal e visual-pictórico conduz à aprendizagem. O processamento ativo inclui a organização de palavras e imagens dentro de modelos pictóricos e verbais coerentes, seguida pela integração entre ambos os modelos ${ }^{49}$. O processo de aprendizagem ocorre com maior facilidade quando o material apresentado inclui tanto representações pictóricas quanto verbais.

Os princípios sugeridos por Mayer para a criação de material para ensino multimídia

são:

MULTIMÍDIA: quando são utilizados os canais audio-verbal e visual-pictórico o aprendizado é mais efetivo do que quando apenas um deles é utilizado. Assim, existe uma maior tendência à ocorrência deste processo se o material multimídia envolve a exibição de palavras e imagens, ao invés de apenas palavras. Este princípio é coerente com os estudos de Rieber ${ }^{50}$ que apontam para um melhor aprendizado dos estudantes em aulas de ciências baseadas em atividades no computador que englobam gráficos e animações.

CONTIGÜ̉IDADE: a apresentação simultânea de palavras e imagens é preferível à apresentação sucessiva de ambas na elaboração de material multimídia. A apresentação simultânea favorece o estabelecimento de conexões coerentes entre palavras e imagens, que pode resultar em um favorecimento do aprendizado.

COERÊNCIA: o processo de aprendizagem é favorecido quando palavras, sons e imagens que não estão estreitamente relacionadas ao assunto que se pretende ensinar são excluídos. Pesquisas de Renninger e colaboradores ${ }^{51}$ corroboram este princípio ao afirmarem que adições (textos/sons/imagens) interessantes, porém não relevantes ao contexto, não favorecem o aprendizado e algumas vezes o impede.

MODALIDADE: narrações são preferíveis a legendas quando na explicação de representações pictóricas. Este princípio foi também identificado por Mousavi e colaboradores ${ }^{52}$ em aplicação de exercícios de geometria. Neste caso, os estudantes aprenderam a resolver problemas de geometria de forma mais produtiva através da utilização simultânea de ilustrações e narração do que de ilustrações e de texto escrito. Assim, no caso da química, por exemplo, o emprego de texto escrito e animação, na produção de um material multimídia pode sobrecarregar o canal visual, enquanto a substituição do texto escrito pela narração levaria a uma maior disponibilidade para o entendimento da animação.

REDUNDÂNCIA: similar ao princípio da modalidade, afirma que em casos nos quais possam ser utilizadas narrações e legendas, é indicado apenas o uso de narrações em vez da utilização de ambas.

INTERATIVIDADE: melhorias no processo de aprendizagem são observadas quando é permitido aos estudantes controlar a velocidade de apresentação do 
material que esta sendo exposto. Desta forma, permite-se ao aprendiz que ative os processos cognitivos respeitando o seu próprio ritmo, reduzindo as chances de uma sobrecarga nos canais que formam o sistema cognitivo.

SINALIZAÇÃO: a sinalização de pontos-chave do conteúdo facilita o aprendizado. Se os sinais direcionam a atenção do estudante para eventos importantes, a integração entre as informações pode vir a ocorrer de forma satisfatória.

PERSONALIZAÇÃO: a apresentação das palavras presentes no material multimídia em estilo coloquial leva a uma melhor performance dos estudantes do que a apresentação em estilo informativo.

No sítio de Internet desenvolvido foram considerados os princípios da multimídia, contigüidade, coerência, interatividade, sinalização e personalização. Os princípios da modalidade e da redundância não foram aplicados visto que requerem a presença de sons no material. Apesar de, em nosso Instituto, os computadores destinados aos alunos de graduação possuírem este recurso, esperávamos que os alunos também acessassem o material fora da universidade. Assim a utilização de sons foi excluída deixando o material passível de uso em um maior número de computadores.

\subsection{Princípios básicos de projeto gráfico (design)}

Alguns artigos presentes na literatura destacam a importância do projeto gráfico e da diagramação para o uso e aceitação pelos estudantes deste tipo de material ${ }^{41,53}$. O projeto de um material gráfico é o responsável por uma boa comunicação, e a intenção no seu desenvolvimento é a de tornar o "produto" (material gráfico) agradável e de uso confortável ${ }^{42}$. Segundo Radfahrer ${ }^{42}$, para a execução de um projeto consistente, conceitos estéticos relacionados à função e estrutura podem ser resumidos em princípios básicos ${ }^{42,43}$ que raramente são utilizados individualmente. Estes princípios básicos de projeto-gráfico podem ser assim definidos:

Proximidade e alinhamento: itens relacionados entre si devem ser agrupados para que sejam vistos como um conjunto coeso e não um emaranhado de partes. A Gestalt $^{54}$ sugere que o cérebro humano reconhece e agrupa elementos próximos entre 
si, e desta forma dá sentido a esses elementos. A proximidade sugere ao leitor por onde começar e onde terminar a leitura. $\mathrm{O}$ alinhamento é responsável pelo conforto e organização dos elementos durante a leitura.

Equilíbrio, proporção e simetria: todo elemento visual em um projeto gráfico possui um peso com relação à página. A combinação correta de elementos com pesos diferentes à direita ou à esquerda, acima ou abaixo, criando simetria e equilíbrio e buscando uma unidade visual, compreende este princípio.

Contrastes, cores e brancos: se dois elementos não são exatamente os mesmos, devem ser diferenciados completamente ${ }^{43}$. Criando uma hierarquia visual forte, diferenciando grupos de elementos, gera-se contraste. Quando não há contraste, há conflito. O conflito acontece quando elementos não-relacionados são exibidos de maneira similar, desestruturando a organização do material. Áreas em branco também são muito importantes em um projeto gráfico, pois delimitam claramente grupos de elementos reforçando a unidade.

Ordem, consistência e repetição: estes princípios são os responsáveis por tornar um material gráfico mais interessante e atrativo, o que conseqüentemente facilita o ato de leitura. A ordenação e repetição de elementos em um material gráfico conferem consistência ao trabalho como um todo.

Simplificação: a simplificação de um projeto gráfico auxilia na elegância, objetividade e clareza da informação a ser transmitida. O que está de acordo com um princípio da Bauhaus: "Less is more"

Integração: provavelmente o mais importante princípio, pois se baseia na tentativa de atingir a unidade. Após todos os elementos terem sido definidos perante os seis princípios anteriores, a interação entre os elementos deve seguir as mesmas regras.

\subsection{Diagramação}

O termo diagramação vem do latim diagramma, que significa desenho geométrico usado para demonstrar algum problema, resolver alguma questão ou representar graficamente a variação de um fenômeno ${ }^{44}$.

Em termos de programação visual, a diagramação é a configuração gráfica de uma mensagem colocada em determinado "campo" (página de livro, revista, jornal), que serve de modelo para sua produção em série. Sua função principal é dar à mensagem a devida estrutura para que o leitor possa discernir rápida e confortavelmente o que lhe representa algum interesse $^{44}$. Princípios de diagramação relevantes são: 
Legibilidade e Leiturabilidade: a legibilidade é um simples ato formal. A condição de identificar letras e palavras, a capacidade de ler o texto escrito. Entretanto nem sempre a legibilidade do texto corresponde a leiturabilidade, que pode ser entendida como a capacidade de entender e interpretar o texto.

Zonas de visualização da página impressa: em qualquer página impressa podem ser determinadas zonas de visualização. Estas zonas são regiões que o olho percorre no primeiro momento da leitura. Quando alguém recebe algum material escrito, instintivamente sua visão se fixa no lado superior esquerdo do papel visto que estamos condicionados a saber que o começo da escrita ocidental é no canto superior esquerdo. Em uma página impressa podemos identificar cinco zonas de visualização como na Figura 2.

1- Zona primária,

2- Zona secundária,

3- Zona morta,

4- Zona morta,

5- Centro ótico,

6- Centro geométrico.

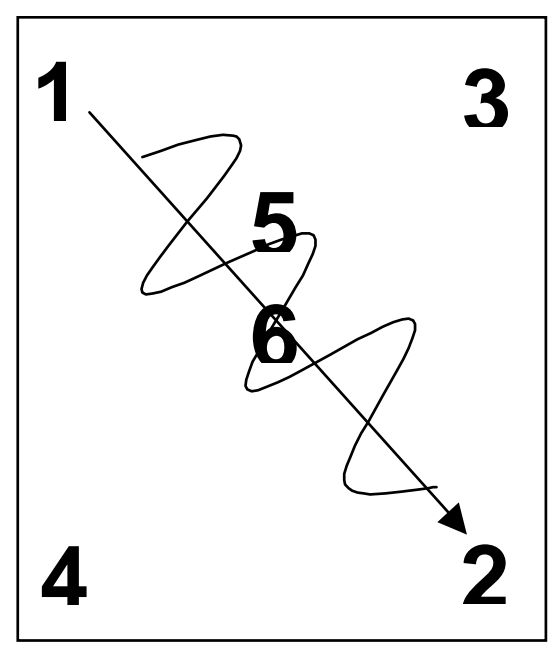

Figura 2: Zonas de visualização da página impressa. 1-Zona primária, 2-Zona secundária, 3Zona morta, 4-Zona morta, 5-Centro ótico, 6-Centro geométrico. ${ }^{44}$

A zona primária deve conter um elemento forte para atrair a atenção e interesse do leitor. Como a visão se desloca direto da zona 1 para a zona 2, deve-se preencher as zonas mortas (zonas 3 e 4) e o centro ótico (zona 5) com elementos atrativos, conduzindo a leitura de forma agradável. 


\subsection{Lay-out definido para o sítio}

Como dito anteriormente, raramente apenas um princípio básico de programação visual é utilizado em um projeto. No sítio de Internet por nós construído, tentou-se aplicar o maior número de princípios de design e diagramação. Uma página geral resultante do nosso projeto é reproduzida na Figura 3.

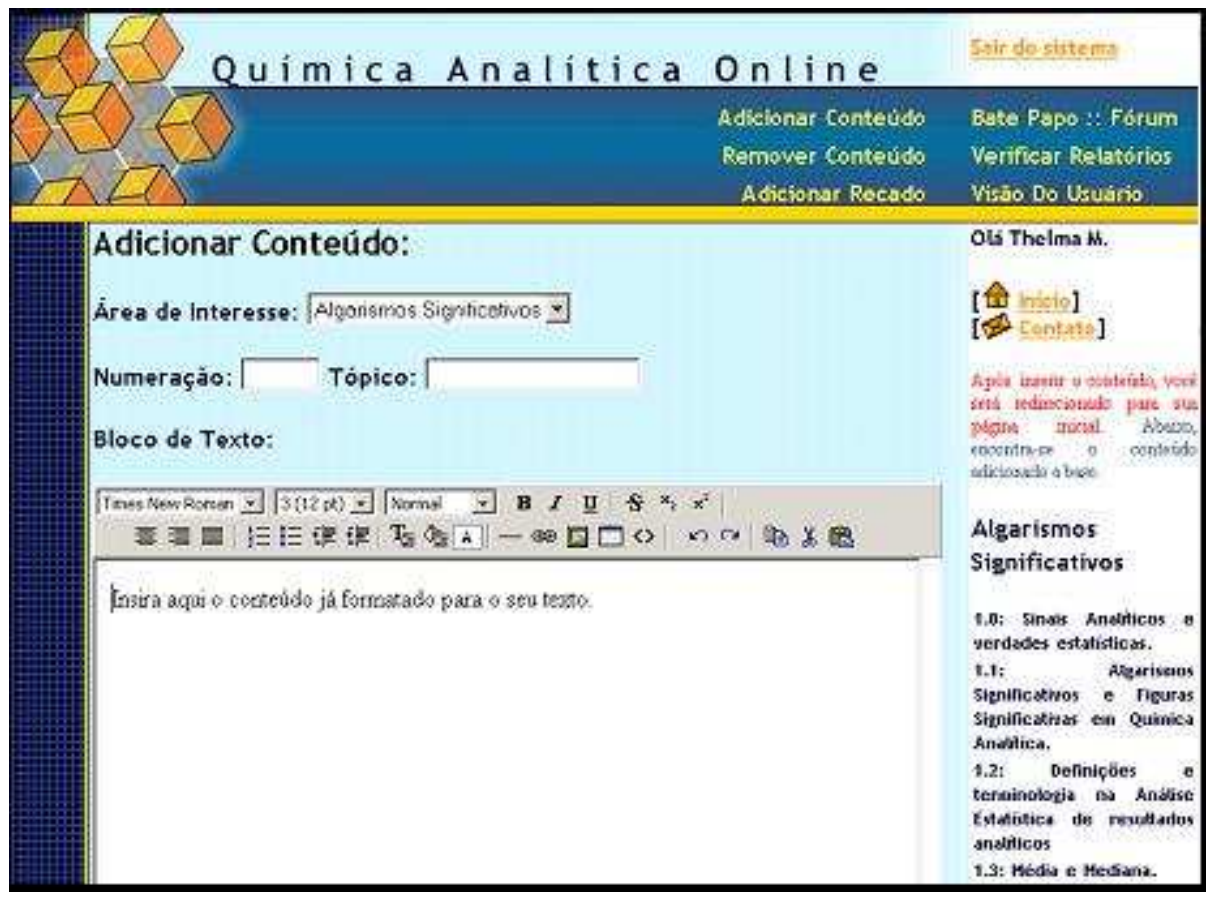

Figura 3: Página resultante do projeto gráfico apresentando três zonas principais; A barra horizontal no topo da página que contém os links principais, a zona principal de conteúdo e a barra lateral (branca) de menus secundários e textos explicativos.

Iniciando a análise deste projeto pelo canto superior esquerdo, pode-se observar a "marca" do sítio, colocada nesta posição visando-se obter destaque e direcionar a visão do usuário a este ponto, coincidente com a leitura ocidental. A marca está inserida em uma barra larga azul e amarela, que percorre toda a página sem sobreposições, o que confere contraste com outros elementos da página. A barra contém do lado direito o menu de navegação principal, também em amarelo (princípio de cores), o que também confere contraste com o 
azul da barra. O fundo da página é dividido em duas cores, azul claro e branco, conferindo ordem e alinhamento entre a zona principal de conteúdo (área em azul) e a zona secundária (em branco). Títulos, sub-títulos e links são escritos em tipografia não-serifada (Trebuchet) em 18, 16 e 14 pontos (pixels) e em negrito ou não, o que confere pesos a estes elementos; e blocos de texto em tipografia serifada (Times New Roman) com cores diferentes tais como o azul marinho para textos descritivos, e vermelho para avisos e regras de utilização, o que confere melhor legibilidade à página. O menu secundário de navegação localizado na zona em branco é colocado logo abaixo do nome de usuário (conseqüentemente perto do menu principal), conferindo ordem e proximidade. A área principal do conteúdo (zona azul claro) contém tópicos e textos alinhados à esquerda com clara separação entre os elementos (tópicos, sub-tópicos e blocos de texto), conferindo pesos e brancos ao material. A repetição das posições destes elementos em todas as páginas do sítio (sejam de conteúdo ou interação) confere repetição, consistência e integração necessárias ao projeto.

\subsection{Modelo de Aceitação de Tecnologia}

O Modelo de Aceitação de Tecnologia (MAT), busca auxiliar os responsáveis pela implementação de sistemas de informação a avaliar sua aceitação ${ }^{55}$.

Segundo Davis ${ }^{56}$, as pessoas tendem a usar ou não uma aplicação ou tecnologia de acordo com a possibilidade de melhorar seu desempenho no trabalho. Isso é chamado de Utilidade Percebida". No entanto, mesmo que o usuário entenda que um determinado aplicativo é útil, sua efetiva utilização pode ser prejudicada se o uso for considerado muito complicado, de modo que os benefícios da nova tecnologia não compensem o esforço do uso. Esse conceito é chamado de Facilidade Percebida. Testes conduzidos por Davis ${ }^{56}$, Mathieson 
e colaboradores ${ }^{57}$ e $\mathrm{Chau}^{58}$, entre outros, indicaram que a utilidade percebida é fortemente influenciada pela facilidade percebida de uso, conforme mostra a Figura 4.

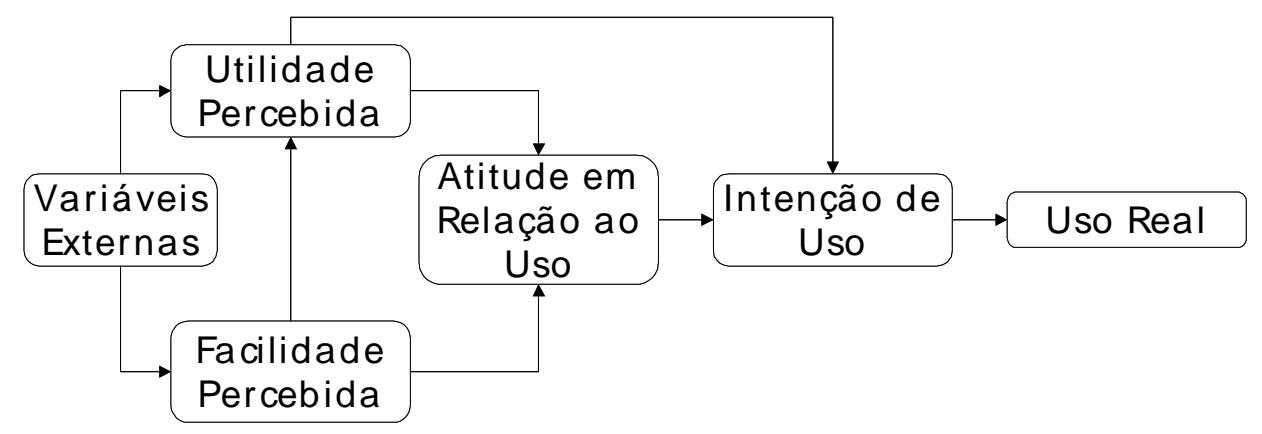

Figura 4: Modelo de aceitação de tecnologia. Os rótulos indicam os construtos considerados e as setas indicam a influência de um construto em outro.

Tanto a Facilidade Percebida quanto a Utilidade Percebida influenciam a atitude que o usuário terá em relação ao sistema, que é um fator determinante da forma como o sistema será aceito. Dentro do conceito do MAT, a atitude representa o desejo do usuário de utilizar o sistema. E, influenciada pela Utilidade Percebida e pela atitude em relação ao sistema, está a intenção de uso. É a intenção que determinará o Uso Real do sistema. Segundo Mathieson e colaboradores $^{57}$, diversos testes empíricos sugerem que o MAT efetivamente prevê e possibilita melhor compreensão das intenções do uso real de sistemas de informação.

Todos os construtos do MAT se referem a percepções e crenças de um indivíduo tomando decisões de adoção de tecnologia num determinado tempo. Como o modelo é comportamental, pode referir-se somente a questões diretamente relacionadas com o usuário e suas percepções sobre o uso do sistema. Por isso, os construtos devem ser desenvolvidos de modo a captar opiniões pessoais.

Baseados nos conceitos acima apresentados, e em analogia ao trabalho de Selim ${ }^{45}$, que trata da aplicação do MAT na investigação da aceitação dos cursos aplicados via Web junto a alunos universitários, são três os construtos usados no desenvolvimento desta 
dissertação: Facilidade de Uso Percebida do Curso via Web (FPCW), Utilidade Percebida do Curso via Web (UPCW) e Uso Real do Curso via Web (URCW). Cada um dos construtos será avaliado por um número distinto de afirmações que serão respondidas pelos estudantes fazendo uso de escala Likert. Para os construtos Facilidade Percebida e Utilidade Percebida utilizamos 6 afirmações, enquanto que 4 foram utilizadas para o construto Uso Real do sistema, conforme ilustra o esquema abaixo (Figura 5). As afirmações, que se encontram ilustradas no Quadro 1, foram propostas por Selim ${ }^{45}$.

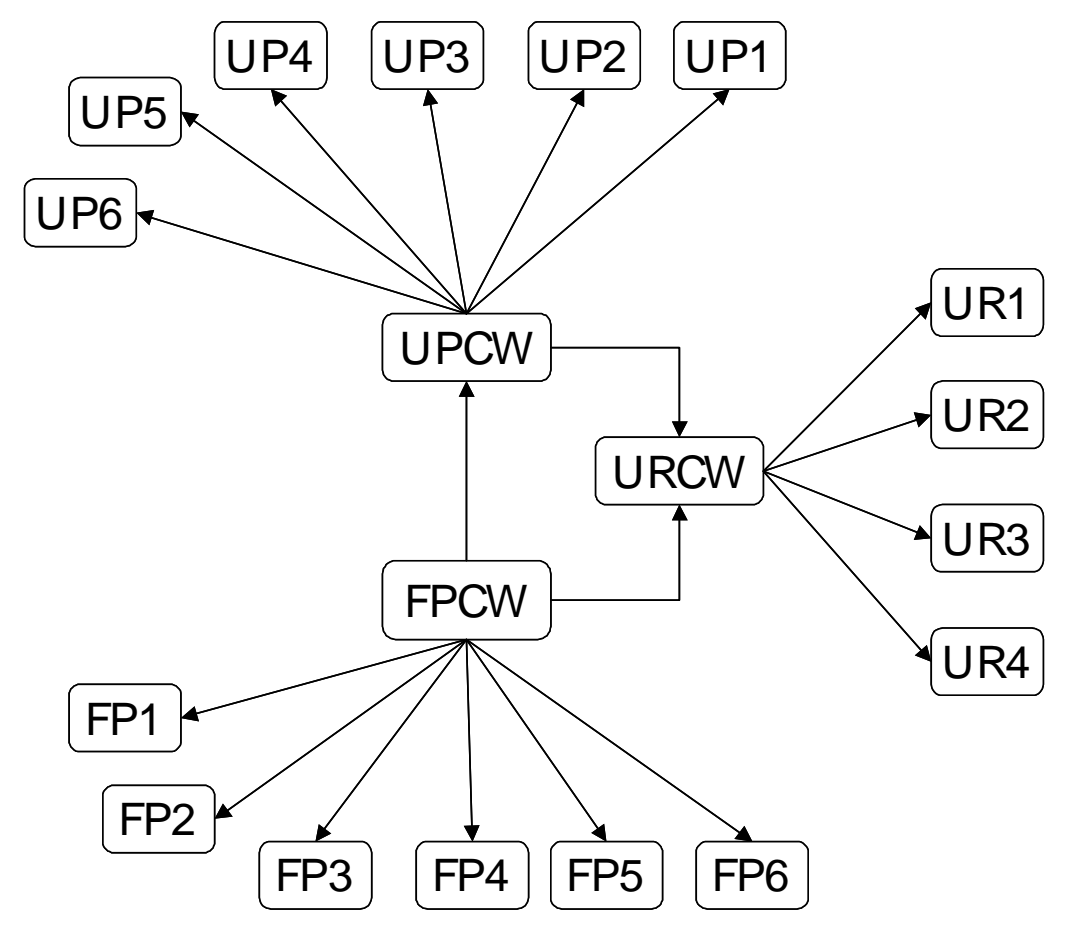

Figura 5: Construtos utilizados no modelo de aceitação de tecnologia e suas afirmações. As setas representam a influência de um construto em outro e os rótulos periféricos representam os indicadores usados na confirmação do construto.

Os resultados obtidos a partir da aplicação do MAT são freqüentemente analisados utilizando técnicas estatísticas ${ }^{45}$. No entanto, o modelo pode também ser utilizado como base para uma metodologia qualitativa, conforme trabalho desenvolvido por Saleh ${ }^{59}$.

Cabe ainda destacar que o MAT tem sido amplamente testado e validado e artigos a ele referentes têm sido publicados em periódicos de renome: MIS Quarterly, Decision 
Science, Systems Research, entre outros. Existem mais de 400 citações das principais referências do MAT, que são Davis ${ }^{56}$ e Venkatesh e Davis ${ }^{60}$. Entre os estudos reportados na literatura que mencionam a aplicação do MAT em ambientes de ensino destaca-se o de Lee e colaboradores $^{61}$, que o aplicaram na avaliação de um projeto de ensino à distância que visava desenvolver a capacidade dos estudantes, distribuídos em diferentes regiões, de interagirem efetivamente no desenvolvimento de sistemas aeroespaciais. Para que este objetivo fosse atingido fez-se necessário o desenvolvimento de uma ferramenta, cujo principal módulo baseava-se na WWW.

\begin{tabular}{|l|l|}
\hline \multicolumn{2}{|l|}{ UTILIDADE PERCEBIDA } \\
\hline UP1 & A utilização do Website melhora a qualidade do curso que eu realizo. \\
\hline UP2 & A utilização do Website me permite realizar tarefas do curso mais rapidamente. \\
\hline UP3 & A utilização do Website torna mais fácil o estudo da matéria. \\
\hline UP4 & A utilização do Website aumenta minha produtividade. \\
\hline UP5 & A utilização do Website aperfeiçoa minha eficácia nos trabalhos do curso. \\
\hline UP6 & Eu acho o Website útil no andamento do curso. \\
\hline FACILIDADE DE USO PERCEBIDA \\
\hline FP1 & O uso do Website é fácil pra mim. \\
\hline FP2 & É fácil para eu aprender a usar o Website e todas suas funcionalidades. \\
\hline FP3 & Eu acho o Website fácil de usar. \\
\hline FP4 & Eu achei o Website de fácil interação. \\
\hline FP5 & Minha interação com o Website é simples e fácil. \\
\hline FP6 & Eu acho fácil obter a informação que eu quero pelo Website. \\
\hline USO REAL \\
\hline UR1 & Eu uso muito o Website em minhas tarefas no curso. \\
\hline UR2 & Eu uso o Website sempre que possível em minhas tarefas no curso. \\
\hline UR3 & Eu uso freqüentemente o Website para realizar minhas tarefas no curso. \\
\hline UR4 & Eu uso o Website nas tarefas do curso apenas quando acho apropriado. \\
\hline
\end{tabular}

Quadro 1: Representação dos 3 construtos analisados e os indicadores sugeridos por Selim ${ }^{45}$. 


\section{METODOLOGIA DE PESQUISA}

A proposta de utilização do sítio de Internet por nós produzido foi aplicada junto aos alunos matriculados na disciplina de Laboratório de Química Analítica Quantitativa (SQM206), do Instituto de Química de São Carlos, Universidade de São Paulo, no segundo semestre de 2004. Esta disciplina, com carga horária de 8 créditos, é oferecida no terceiro semestre do curso de Bacharelado em Química. É uma disciplina de caráter experimental que tem como objetivo desenvolver no aluno as habilidades necessárias à execução de métodos quantitativos de análise convencional e fixar o conceito de equilíbrio químico. Os conteúdos presentes na ementa da disciplina são: avaliação de resultados experimentais de análise química; métodos volumétricos de ácido-base; precipitação; complexação e oxidação-redução; métodos gravimétricos de análise; teoria da formação de precipitados e troca iônica ${ }^{62}$.

O funcionamento da disciplina pode ser sucintamente descrito da seguinte forma: no início do semestre são disponibilizadas informações gerais sobre a sua forma de condução pelo docente, assim como os roteiros das aulas práticas e o cronograma das atividades que serão realizadas no período. No início de cada aula o docente responsável faz uma breve revisão dos passos a serem seguidos na execução da prática de laboratório, dos principais conceitos nela abordados e dos cálculos a serem realizados durante a sua execução ou após a sua conclusão. Os alunos executam a prática individualmente e são responsáveis pela vidraria utilizada, pela montagem do(s) aparato(s) e pelos resultados obtidos. Após uma semana da realização da prática os alunos entregam ao docente um relatório individual contendo os seguintes tópicos: Introdução; Fundamentação Teórica; Materiais e Métodos; Resultados e Discussão; Conclusão. Os critérios de avaliação adotados na disciplina se pautam nos 
resultados das análises realizadas pelos alunos nas aulas práticas semanais e no conteúdo dos relatórios por eles produzidos sobre os referidos resultados.

Descrevemos a seguir os sujeitos da pesquisa, as etapas de aplicação da proposta de utilização do sítio de Internet e os instrumentos de coleta de dados empregados.

\subsection{Sujeitos}

No semestre de aplicação da proposta a disciplina contava com 56 alunos, distribuídos em duas turmas, que chamaremos a partir de agora de Turma 1 e Turma 2. Cada turma contava com um docente, que era assistido por um estagiário do Programa de Aperfeiçoamento de Ensino $(\mathrm{PAE})^{*}$. Cabe ressaltar que neste semestre atuamos como estagiário PAE na Turma 1.

Cadastraram-se no sítio 32 alunos, 19 da Turma 1 e 13 da Turma 2, que foram tomados como sujeitos da pesquisa. Cabe ressaltar que apenas 18 dos 32 alunos cadastrados no sítio concluíram as três etapas de aplicação da proposta, descritas em detalhes no tópico subseqüente e responderam aos dois questionários aplicados durante o processo, também descritos a seguir.

Os professores de ambas as turmas foram também tomados como sujeitos da pesquisa. Uma vez que atuamos como estagiário PAE da Turma 1, apenas o estagiário da Turma 2 foi tomado como sujeito da pesquisa.

"Disponível em: 〈http://www.iqsc.usp.br/iqsc/ensino/pae/default.php> 


\subsection{Descrição do processo de aplicação da proposta}

Inicialmente procuramos os professores responsáveis pela disciplina, no referido semestre, com o intuito de expormos as bases da proposta e esclarecermos possíveis questionamentos a respeito da sua implementação. Salientamos que a aplicação da mesma exigiria apenas o acesso dos alunos à Internet (já garantido pela própria instituição, que dispõem de uma sala com 14 computadores para uso dos alunos de graduação, chamada de Sala Pró-Aluno) e que este acesso ocorreria em horários extra-classe. Desta forma, a aplicação da proposta não implicaria em grandes modificações na dinâmica usual da disciplina. Após o êxito nesta primeira conversa passamos a selecionar o conteúdo da área de química que deveria estar presente no sítio e a trabalhar na sua construção. $O$ conteúdo utilizado foi fornecido pelo Professor Wagner Luís Polito, docente do Instituto de Química de São Carlos.

Tendo concluído a elaboração e construção do sítio, passamos à aplicação do mesmo junto aos alunos matriculados na disciplina. Esta aplicação se deu através do cumprimento das seguintes etapas:

1. Os alunos tomaram ciência sobre a pesquisa que iríamos desenvolver e sobre os seus objetivos na primeira aula de laboratório ministrada no semestre. Nesta ocasião também tiveram conhecimento do endereço de acesso ao sítio e das regras para sua utilização. Foram instruídos a, caso julgassem conveniente, realizar o cadastro no sítio e a partir de então utilizálo livremente na realização de operações cotidianas da disciplina. Foram também avisados da possibilidade de contato com os estagiários, via formulário de contato disponível no sítio e em monitorias realizadas por 1 hora nas quintas-feiras, com o estagiário PAE da Turma 1 e 1 hora nas quartas-feiras com o estagiário PAE da Turma 2. Estas instruções foram dadas em ambas as turmas pelo estagiário da Turma 1, em um intervalo de aproximadamente 20 minutos. 
2. Ao final da primeira aula acompanhamos 5 alunos de cada turma à Sala PróAluno, quando eles tiveram um primeiro contato com o sítio. Este contato serviu para mostrar-lhes as formas de acesso e utilização do sítio e para sanar possíveis dúvidas sobre o seu funcionamento. Assumimos o acesso e a utilização de sítios de Internet como atividades familiares aos alunos do curso de graduação do Instituto e não oferecemos aulas ou treinamentos adicionais para utilização do sítio em questão. Apresentamos o sítio aos 10 alunos acreditando que estes repassariam as informações a outros alunos interessados em uma espécie de "propaganda" boca-a-boca.

3. Após a realização do cadastro, os alunos puderam utilizar livremente o sítio da forma que achassem mais indicada e eficiente. Novas instruções e avisos, a respeito da utilização do sítio não foram dadas durante todo o semestre letivo. Apenas sugestões de utilização do sítio foram feitas aos estudantes para que sanassem suas dúvidas. Nenhuma atividade obrigatória foi exigida aos alunos cadastrados e nenhum comunicado ou aviso relacionado à disciplina foi veiculado estritamente pelo sítio. Ou seja, a utilização do sítio não se apresentou como uma atividade obrigatória para os alunos em nenhuma ocasião.

\subsection{Instrumentos de coleta de dados}

A coleta de dados foi realizada a partir da aplicação de dois questionários, um de caracterização e outro de avaliação, e através do monitoramento da navegação dos alunos. Estes instrumentos de coleta foram aplicados em momentos distintos da pesquisa: o primeiro questionário foi aplicado no início do semestre, quando os alunos preencheram o cadastro no sítio, e o segundo após o término do semestre letivo. O monitoramento da navegação ocorreu durante todo o semestre.

Foram também realizadas entrevistas semi-estruturadas com os professores e com o 
estagiário da Turma 2.

\subsubsection{Cadastro no sistema e questionário de caracterização}

Para efetuar o cadastro no sistema foram solicitadas as seguintes informações aos alunos: nome completo, idade, e-mail, número USP (login), senha, ano de ingresso na USP, turma a que pertence (se aluno da Turma 1 ou da Turma 2). Estas informações foram coletadas com o objetivo principal de identificar os aluno nas ações realizadas no sistema e de monitorar a navegação de cada um deles. No ato do cadastro os alunos também responderam a um questionário de caracterização. Nele estavam contidas 12 perguntas de múltipla escolha e uma questão aberta que foram aplicadas visando obtenção de informações acerca da idade, origem, profissão, formação anterior, familiaridade dos alunos com o uso da Internet e suas intenções iniciais com relação ao uso da ferramenta. O questionário de caracterização encontra-se no Anexo B desta dissertação.

\subsubsection{Monitoramento da navegação}

Uma ferramenta escrita em JAVA foi desenvolvida visando obtenção de informações acerca da navegação dos alunos no sítio. Esta ferramenta é capaz de armazenar, em ordem cronológica, o nome do aluno, número USP (login), a página acessada, data e hora de acesso e foi inserida nas seguintes páginas do sítio: páginas de conteúdo, envio de e-mail, envio de relatório e página de rosto. A ferramenta JAVA encontra-se descrita no capítulo Construção do Sítio de Internet desta dissertação. As informações de navegação foram coletadas no período de 20 de Setembro de 2004 a 2 de Janeiro de 2005.

\subsubsection{Questionário de avaliação}

Ao final do semestre letivo os alunos responderam, voluntariamente, a um questionário de avaliação que foi aplicado visando obtenção de informações acerca das suas 
percepções sobre o conteúdo, Utilidade do sítio, Facilidade de Uso e Uso Real do sítio. Nele estavam contidas 24 questões: as 16 primeiras dizem respeito aos três construtos referentes ao modelo de Aceitação de Tecnologia ${ }^{45}$, Utilidade Percebida, Facilidade de Uso Percebida e Uso Real, correspondendo respectivamente às questões 1 a 6,7 a 12, e 13 a 16. As questões 17 a 23 versam sobre a efetividade da ferramenta como material de apoio ao ensino de laboratório e a questão 24 visa captar sugestões para melhorias no sítio.

As questões 17 a 23 foram introduzidas no questionário tendo em vista colocações presentes em trabalho reportado por Weaver ${ }^{28}$. A afirmação 17 diz respeito à utilidade do sítio para o aprendizado de novos conceitos; as afirmações 18 a 20 tratam da utilização do sítio no reforço de conceitos já aprendidos. As últimas 3 questões, 21 a 23, são de caráter geral e tratam de impressões e perspectivas dos alunos no que diz respeito à utilização do sítio. Para quantificação das respostas dadas a estas questões foi usada uma escala tipo Likert com cinco pontos, variando entre "Concordo Fortemente" e "Discordo Fortemente". Ao final do questionário foi adicionada uma questão aberta, que permitia ao aluno sugerir modificações para a melhoria da aplicação. O questionário de avaliação encontra-se no Anexo C desta dissertação e foi disponibilizado apenas após a conclusão da disciplina.

Fizemos a análise dos dados obtidos com o objetivo de tecer considerações sobre a aceitação, forma de utilização do sítio pelos alunos de graduação em química e sobre a sua potencialidade no apoio ao ensino de laboratório. 


\section{CONSTRUÇÃO DO SÍTIO DE INTERNET}

Para elaboração do sítio em questão fez-se necessário o estudo de algumas linguagens de programação e formatação. O sítio foi construído utilizando princípios do padrão Modelo-Visão-Controle (MVC), base de dados MySQL (Structured Query Language) e as linguagens de programação e formatação: JAVA, HTML e CSS (Cascade Style Sheets). Para que o desenvolvimento deste capítulo se torne claro, é necessária uma explicação dos conceitos citados acima. Não pretendemos exaurir o assunto, mas sim oferecer ao leitor uma visão geral das tecnologias envolvidas, uma vez que informações aprofundadas a respeito, assim como arquivos de exemplos e tutoriais sobre a instalação e configuração dos softwares necessários, podem ser facilmente encontrados na Web.

O sítio em questão é dinâmico, ou seja, o seu conteúdo é armazenado separadamente do código e, a cada requisição do usuário a uma determinada página, ela é reconstruída de forma a exibir o conteúdo apropriado ${ }^{16}$. Sua estrutura segue os padrões de uma Web Application e está publicado em um provedor comercial que utiliza o Container TomCat (como servidor Web) no processamento das páginas. Como o provedor escolhido é comercial não foram necessários passos de instalação ou configuração do servidor; informações sobre sua instalação e configuração também podem ser encontradas na Web ${ }^{63}$.

\subsection{A estrutura de uma Web Application}

Uma Web Application pode ser definida como uma hierarquia de diretórios e arquivos em um formato padrão, exigidos pelo TomCat ${ }^{63}$. O nível mais alto de diretório é a 
pasta raiz, onde estão alocados os arquivos de interface com o usuário; a partir deste diretório a aplicação é organizada.

1. *.html, *.jsp, etc. - As páginas HTML e JSP que serão exibidas pelo navegador. Para pequenas aplicações, é ideal que se mantenham todas as páginas no diretório "raiz" da aplicação.

2. /WEB-INF/web.xml - O arquivo que descreve o contexto da aplicação. Este arquivo XML descreve os servlets e outros componentes da aplicação, além de parâmetros de inicialização. Existem na Web vários tutoriais sobre este arquivo, então consideramos desnecessária uma explicação mais profunda sobre sua configuração.

3. /WEB-INF/classes/ - Este diretório contém os arquivos de classes necessários à aplicação. Caso as classes sejam organizadas em pacotes, o nome da classe deve se referir nos diretórios dentro desta pasta. Por exemplo, para uma classe chamada com.mycompany.mypackage.MyServlet, o arquivo correspondente é na verdade /WEB-INF/classes/com/mycompany/mypackage/MyServlet.class.

4. /WEB-INF/lib/ - Este diretório contém as bibliotecas (arquivos “.JAR”) necessários à aplicação e desenvolvidos por terceiros, como arquivos de conexão ao banco de dados, ou outras bibliotecas.

5. Usando softwares específicos para desenvolvimento em JAVA, como o Eclipse que é gratuito, outro diretório é criado, mas não é necessário para o funcionamento da aplicação. Este diretório é o /WEB-INF/src/ que armazena os arquivos ".JAVA" para compilação. Com a compilação, arquivos ".CLASS" são gerados e armazenados na pasta /WEB-INF/classes/. 
O Quadro 2 ilustra a estrutura de pastas do nosso sítio.

\begin{tabular}{|c|c|}
\hline$\square$ drisuse & Pasta raiz, armazena as páginas html, jsp etc. \\
\hline$\square$ bloxh & Armazena os arquivos CSS \\
\hline$\square$ powmg & Armazena as figuras pertencentes ao conteúdo teórico \\
\hline p926 & Armazena as imagens utilizadas no sítio \\
\hline$\square \square \mathrm{Pq}$ & Armazena os arquivos javascripts \\
\hline$\theta \square$ ac & Arquivos de idioma do HTMLAREA \\
\hline 10072 & Arquivos de plugin do HTMLAREA \\
\hline$\| P$ & Janelas adicionais do HTMLAREA \\
\hline$\square$ dnel!e & Armazena as funcionalidades da aplicação \\
\hline bloxh & Armazena os arquivos compilados (.CLASS) \\
\hline , folwg & \\
\hline$\square p 928$ & Classes de conexão com o banco de dados \\
\hline$\square \square \mathrm{pq}$ & Classes de formatação da informação \\
\hline$\square_{0} \mathrm{c} 92862$ & Classes de conexão entre computadores \\
\hline$\square \square$ MEB $\|$ L & Classes de inserção, remoção e seleção \\
\hline bobribz & Bibliotecas necessárias \\
\hline 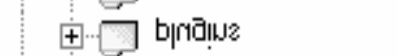 & Arquivos de histórico \\
\hline 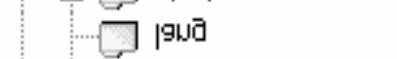 & Arquivos fonte. Arquivos que dão origem às classes \\
\hline$\square$ & \\
\hline$+\square ! \omega g 0 \overline{6}$ & Arquivos-fonte de conexão com o banco de dados \\
\hline 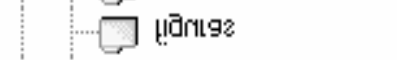 & Arquivos-fonte de formatação da informação \\
\hline$\square \mathrm{c} 2$ & Arquivos-fonte conexão entre computadores \\
\hline 9 - & Arquivos-fonte de inserção, remoção e seleção \\
\hline
\end{tabular}

Quadro 2: Estrutura de diretórios do sítio de Internet que segue o padrão exigido a uma Web Application, contando com a pasta WEB-INF, e as classes organizadas dentro desta pasta.

\subsection{O padrão Modelo-Visão-Controle}

O padrão Modelo-Visão-Controle (MVC) foi inicialmente desenvolvido para mapear tarefas tradicionais de entrada, processamento e saída de dados para o modelo de interação com o usuário. A arquitetura MVC fornece uma maneira de dividir em módulos as funcionalidades de apresentação, tratamento e fluxo dos dados em uma aplicação (Figura 6) ${ }^{64}$. 


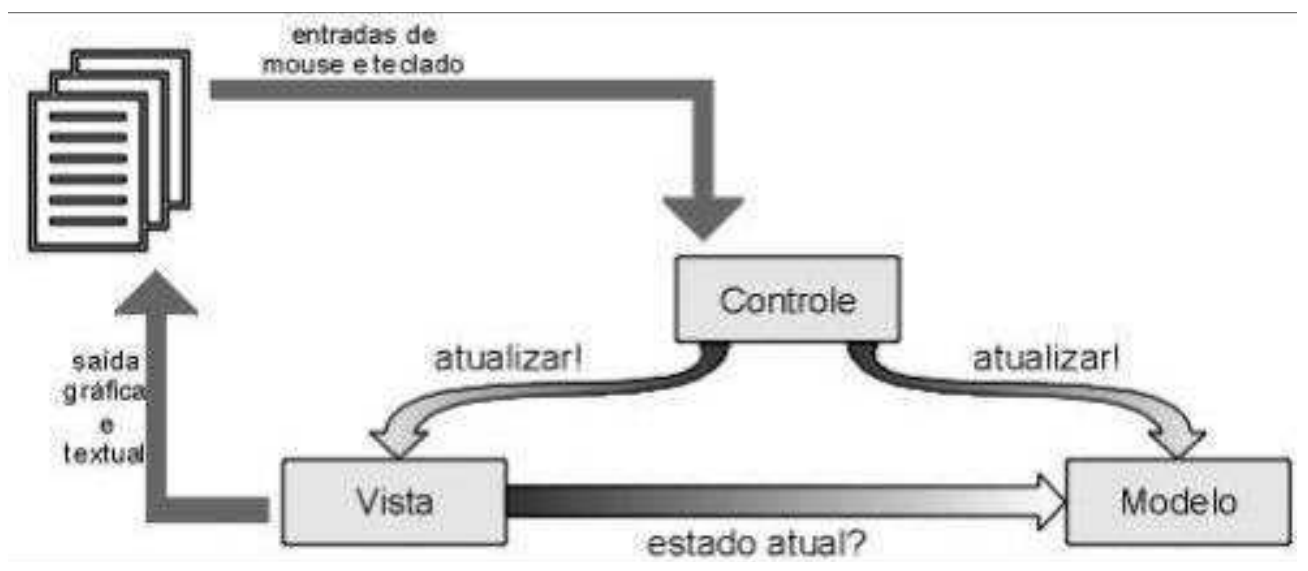

Figura 6: Diagrama geral para o modelo MVC (modelo-visualização-controle) ${ }^{64}$.

$\mathrm{Na}$ arquitetura MVC o Modelo representa as regras do negócio que governam o acesso e a modificação dos dados. São as páginas que armazenam a lógica da aplicação, em nosso caso, escritas em JAVA. O Modelo se preocupa apenas com o armazenamento, manipulação e geração de dados, sendo assim independente da Visualização. A Visualização representa a forma como os dados devem ser apresentados, é a camada de interface com o usuário. A Visualização não se preocupa na forma como a informação foi obtida ou onde ela foi obtida, apenas a exibe. Nesta camada é que se encontram os códigos HTML e CSS responsáveis pela formatação dos documentos. A Visualização é usada para receber a entrada de dados (via formulários) ou apresentar os resultados. O Controle define o comportamento da aplicação, ou seja, determina o fluxo da apresentação, servindo como uma camada intermediária entre a Visualização e a lógica. O Controle interpreta as ações do usuário e as mapeia para as chamadas do Modelo. No caso de um cliente de aplicações Web essas ações do usuário englobam cliques de botões, seleções de menus e envio de dados de formulário. Ou seja, por entradas de mouse ou teclado na camada de Visualização, o usuário pode alterar o estado do sistema. O modelo MVC foi escolhido para este trabalho devido a suas vantagens $^{65}$. Utilizando o modelo MVC a aplicação desenvolvida é escalável, além de tornar o trabalho de manutenção mais fácil. 


\subsection{O fluxo da informação}

Seguindo as orientações para a construção de uma Web Application e, ainda, o modelo MVC, podemos simplificar o fluxo da informação para a nossa aplicação. De maneira geral, o fluxo das informações transmitidas dentro do sítio pode seguir apenas 3 caminhos: inserção, seleção e remoção. No caso de inserção de informação, o usuário visualiza um formulário na camada de Visualização, preenche e submete os dados. A aplicação envia estes dados à camada do Modelo, que trata os dados se necessário, e armazena na base. Uma nova página é retornada ao usuário após a finalização da ação. Em nosso caso, a página de rosto é novamente exibida após um procedimento correto de inserção ou remoção de informação.

No caso de seleção da informação, o usuário recebe uma página na camada de Visualização, escolhe um link e clica, a aplicação determina a página destino via camada de Controle e requisita as informações necessárias à camada Modelo, as informações atualizadas são inseridas na nova Visualização e exibidas ao usuário. No caso de remoção de informação, a camada Visualização exibe o estado atual do sistema, o usuário seleciona a informação a ser excluída e submete o pedido. A ação é executada e a aplicação envia o usuário novamente à página de rosto.

\subsection{O armazenamento da informação}

O MySQL (Structured Query Language) é um banco de dados relacional gratuito, eficiente e otimizado para aplicações Web. O MySQL é desenvolvido e mantido pela empresa MySQL AB, que também oferece uma versão comercial ${ }^{66}$. Esse SGBD (Sistema de Gerenciamento de Banco de Dados) também é multi-plataforma, sendo compatível com o Windows, Linux, BSDs, entre outros sistemas operacionais, e com várias linguagens de 
programação, tais como PHP, C, Java, Visual Basic, entre outras. O fato de utilizar somente recursos essenciais (o que atende à maioria das aplicações de banco de dados existentes) fez com que sua adoção, e conseqüentemente o suporte fossem grandes tornando-o o banco de dados de código aberto mais utilizado no mundo. O MySQL surgiu a partir da necessidade de utilizar algum mecanismo que permitisse a conexão de tabelas criadas na linguagem SQL para um determinado fim ${ }^{67}$.

Em nosso trabalho, utilizamos apenas requisições SQL de inserção, seleção e remoção de dados da base, visto que toda a interatividade oferecida pelo sistema utiliza um destes recursos. A sintaxe geral de seleção, remoção e inserção de dados em uma base MySQL é:

SELEÇÃO

SELECT * FROM nome_tabela WHERE campo= 'variável'; REMOÇÃO:

DELETE FROM nome_tabela WHERE campo= 'variável';

INSERÇÃO:

INSERT INTO nome_tabela VALUES('variável_1','variável_2','variável_3','variável_4');

Onde, o asterisco se refere a todos os campos de um determinado registro que corresponda à variável escolhida; "nome_tabela" se refere a uma determinada tabela da base; "campo" se refere a uma determinada coluna da tabela, e "variável" se refere aos valores que estão sendo inseridos, selecionados ou removidos da base.

\subsection{A linguagem HTML}

A linguagem HTML é destinada à formatação de documentos $\mathrm{Web}^{68}$. Trata-se de uma linguagem interpretada. Todo documento HTML apresenta elementos entre os sinais "<" e ">”. Esses elementos são chamados etiquetas (tags) de HTML, que são os comandos de formatação da linguagem, interpretados diretamente pelo navegador (browser). As etiquetas devem ser abertas e fechadas delimitando o conteúdo a ser formatado. A sintaxe geral para a 
formatação de um conteúdo em um documento HTML é exemplificada abaixo (o sinal de barra usado na segunda etiqueta representa o fechamento da mesma e delimita o conteúdo):

$<$ etiqueta $>$ CONTEÚDO </etiqueta $>$

Alguns elementos são chamados "vazios", pois não marcam uma região de texto, apenas inserem algum elemento no documento. Sua sintaxe geral é:

<etiqueta>

Os elementos também podem conter atributos. Os atributos são utilizados para embutir algum valor (ou variável) a uma determinada etiqueta. Sua sintaxe geral pode ser transcrita como:

<etiqueta atributo1=valor 1 atributo2=valor2 $>\ldots</$ etiqueta $>$

Todo documento HTML possui uma estrutura básica e bem definida para que possa ser reconhecido e interpretado pelo navegador. A sintaxe geral para um documento HTML é descrita abaixo ${ }^{68}$ :

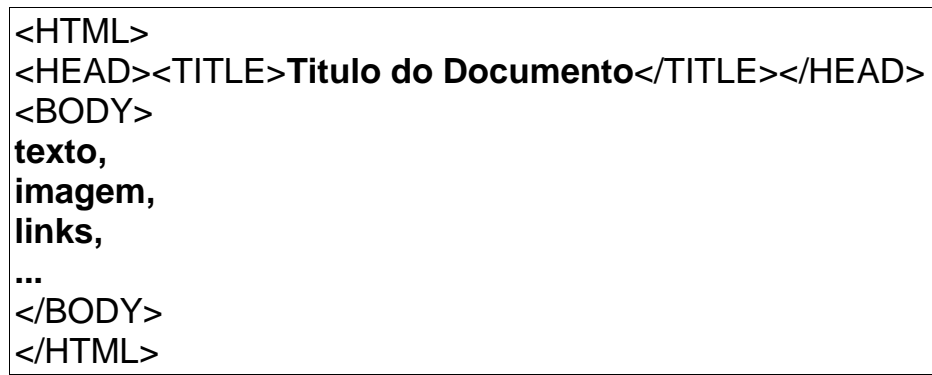

A etiqueta $<$ HEAD $>$ define o cabeçalho do documento e contém informações sobre o mesmo. O elemento <TITLE>, por exemplo, define o título que é mostrado no alto da janela do navegador e deve sempre aparecer dentro da etiqueta $\langle$ HEAD $\rangle$. Todo documento WWW deve ter um título pois, atualmente referenciados em buscas pela rede, fornecem uma identidade ao documento. A etiqueta <BODY> define o corpo do documento. Tudo que estiver contido em <BODY> será mostrado na janela principal do navegador, sendo 
apresentado ao leitor. Esta etiqueta pode conter cabeçalhos, parágrafos, listas, tabelas, links para outros documentos, imagens, formulários, animações, vídeos, sons e scripts embutidos. Como toda etiqueta, a $\langle$ BODY $>$ pode conter atributos. Através de atributos de $\langle$ BODY $\rangle$, podemos definir cores para os textos, para os links, e para o fundo das páginas, bem como uma imagem de fundo (marca d'água) ${ }^{68}$. A sintaxe geral para a etiqueta $\langle$ BODY $>$ incluindo alguns atributos é:

<BODY BGCOLOR="\#rrggbb" TEXT="\#rrggbb" LINK="\#rrggbb" ALINK="\#rrggbb" VLINK="\#rrggbb" BACKGROUND="URL">

Em se tratando de um documento que contenha apenas texto, algumas etiquetas são usadas para a formatação de títulos, tópicos e sub-tópicos. Estas etiquetas são chamadas cabeçalhos e possuem até 6 níveis, de $\langle\mathbf{H 1}\rangle$ a $\langle\mathbf{H 6} \mathbf{}\rangle$.

\subsection{A linguagem CSS (Cascading Style Sheets)}

Cascading Style Sheets ou CSS são estilos para páginas Web que possibilitam a mudança da aparência simultânea de todas as páginas relacionadas com o mesmo estilo ${ }^{69}$. Uma ligação é criada para uma página que contém os estilos (um arquivo de sintaxe bem definida e terminação "css"). Assim, a formatação segue as definições deste novo arquivo e se padroniza para todas as páginas do sítio. Qualquer mudança nos estilos do arquivo "css” altera da mesma forma todas as páginas dependentes deste estilo. As especificações da CSS podem ser obtidas no site da W3C (Word Wide Web Consortium) ${ }^{70}$. Em nosso trabalho utilizamos as CSS na formatação das páginas internas. Um trecho do arquivo "css" é reproduzido no Quadro 3, os estilos das etiquetas são definidos neste arquivo. 


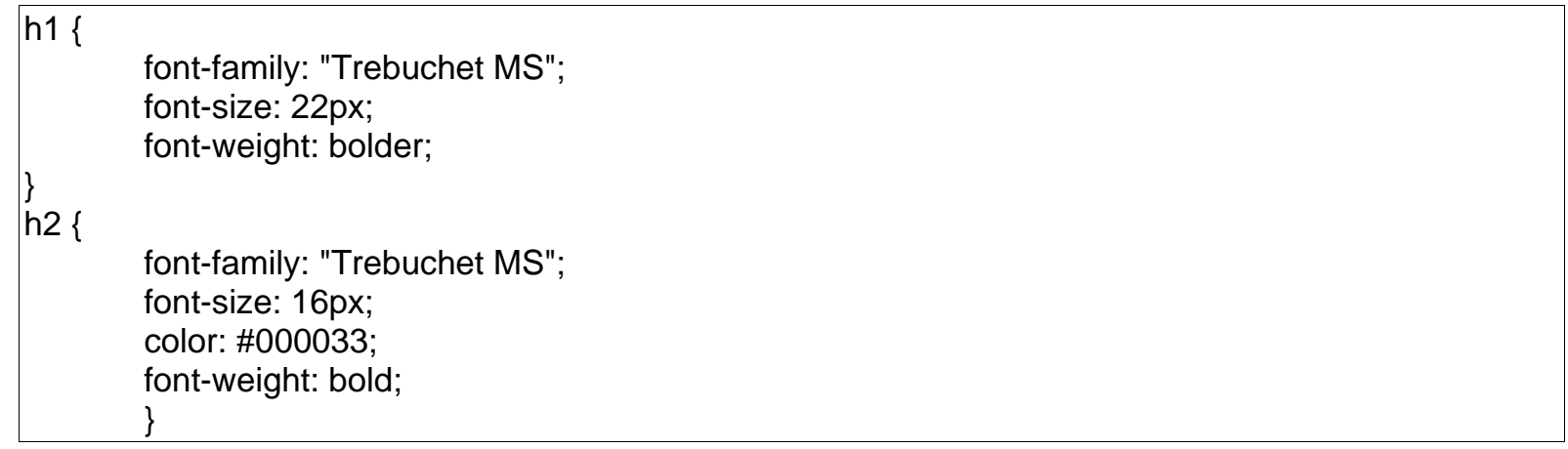

Quadro 3: Sintaxe de um arquivo CSS. São exemplificados os títulos de nível 1 e 2.

\subsection{A linguagem JAVA}

Java é uma linguagem de programação orientada a objetos, desenvolvida pela Sun Microsystems. Inicialmente elaborada para ser a linguagem-base de projetos de software para produtos eletrônicos, a linguagem teve o seu maior crescimento em 1995 devido ao sucesso mundial da World Wide Web ${ }^{71}$. Este sucesso se deve grandemente a duas razões: A Java é simples e independente de plataforma, o que garantiu sua fácil transposição para a Web. A Java é uma linguagem que pode ser tanto compilada quanto interpretada, e nos dias de hoje permite diversas formas de programação tais como javascript, javabeans, servlets e scriptlets. O sítio de Internet por nós construído utiliza javascript (processada no computador do usuário) e scriptlets (processados no servidor), na realização de suas funcionalidades. Exemplos dos códigos javascripts usados assim como os scriptlets serão oportunamente mostrados e comentados.

\subsubsection{Javascript}

O javascript foi desenvolvido para fornecer interatividade em páginas $\mathrm{Web}^{72}$, sem que as mesmas fossem processadas no servidor. Por ser uma linguagem interpretada como o HTML, o javascript é inserido diretamente no código HTML de uma página Web. Em nosso caso, utilizamos javascript na inserção de conteúdo e envio de relatório com a ferramenta 
HTMLArea, no preenchimento de data e hora dos formulários contidos em algumas páginas, e na verificação de dados dos formulários. O Javascript é inserido em uma página HTML entre as etiquetas <script> e </script>. Os scripts de formatação de conteúdo (HTMLArea), inserção de data e hora, e verificação de formulários serão discutidos no tópico Ferramentas deste capítulo.

\subsubsection{Scriptlets}

Os scriplets são trechos de código JAVA, processados no servidor, dentro de páginas $\mathrm{HTML}^{73}$. Um scriptlet é inserido em uma página HTML dentro das etiquetas <\% e $\%>$ como abaixo:

$<\%$ código JAVA\%>

Os scriptlets são utilizados em nosso projeto para requisição das páginas da camada Modelo da aplicação. O scriptlet abaixo é usado no modelo da página interna, processado pelo servidor, e imprime a frase "Olá Nome". A variável "nome" é uma variável de sessão criada no ato de acesso ao sistema e armazena o nome do aluno, extraído da base de dados.

<\%out.print("Olá " +nome);\%>

\subsection{As páginas internas do sítio}

Cabe agora uma explicação mais pormenorizada das páginas internas que compõem o sítio. O código HTML que compõe o modelo principal da página interna do sítio é reproduzido abaixo e permite observar as formas de utilização dos scriptlets, e das etiquetas HTML e seus atributos. Todas as páginas internas do sítio foram construídas sobre o mesmo modelo representado no Quadro 4, e o código em negrito representa trechos diferentes (áreas específicas) para cada página. Os comentários são escritos em cinza, em Times New Roman, itálico, precedidos do sinal //. 


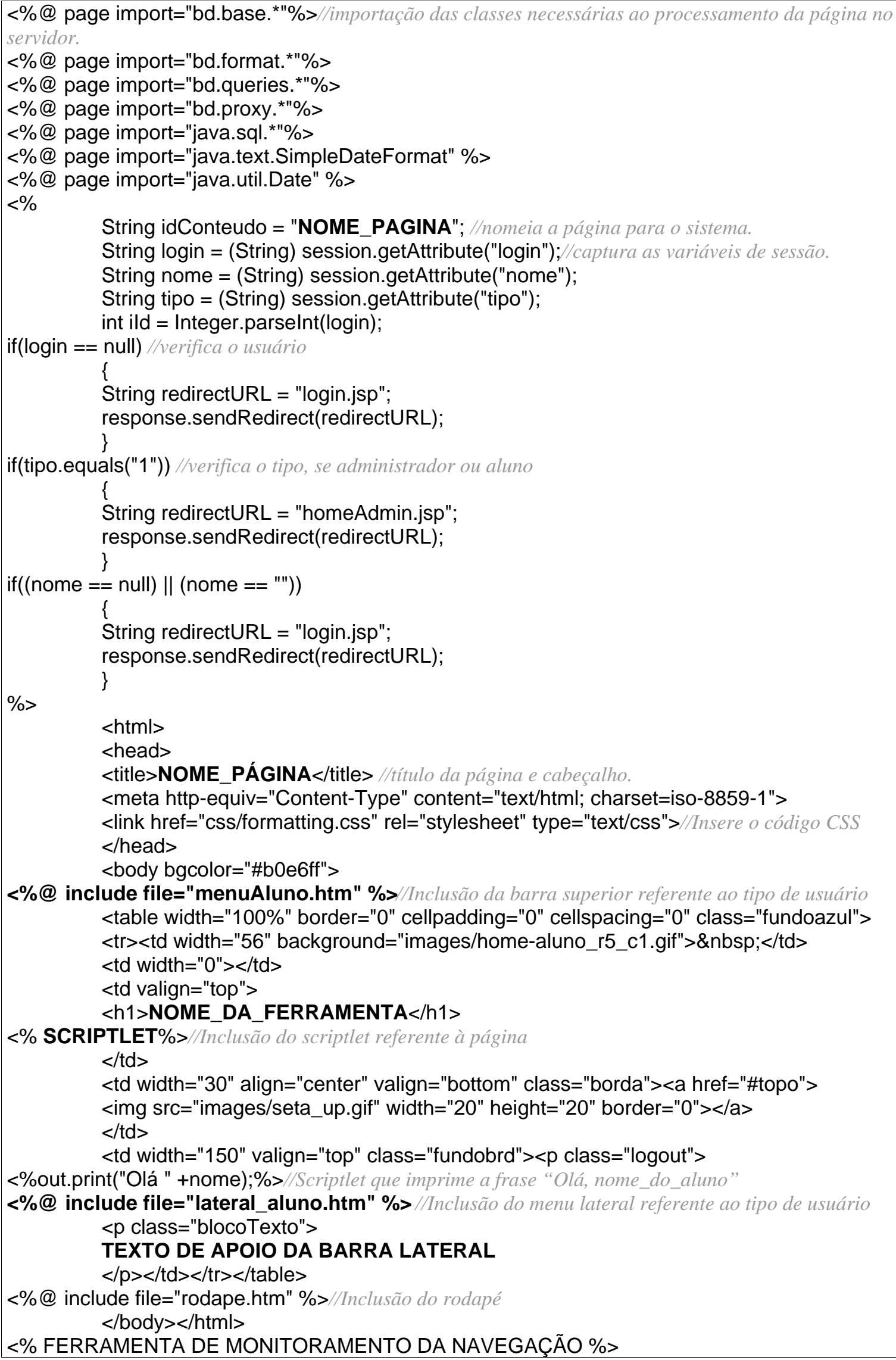

Quadro 4: Código-fonte do modelo geral para as páginas internas do sítio. 


\subsection{Estrutura da base de dados do sítio}

O modelo de base de dados utilizado em nosso trabalho é relacional, ou seja, a base de dados é composta de tabelas bidimensionais (chamadas relações) no qual os registros são organizados em colunas e os dados são armazenados em linhas. A sintaxe geral para criação de uma tabela em uma base de dados MySQL é:

CREATE TABLE 'nome_tabela' ( 'campo' tipo_campo NOT NULL 'valor_inicial');

Neste caso "nome_tabela" corresponde ao nome dado à tabela; "campo" corresponde ao nome de uma determinada coluna; "tipo_campo" corresponde ao tipo de dado que o campo pode armazenar (se inteiro, decimal, texto, etc); "NOT NULL" indica que o campo nunca pode ser vazio; "valor_inicial" corresponde ao valor inicialmente assumido pela base. Várias tabelas foram necessárias em nosso projeto para armazenamento das informações transmitidas via sítio, tais como informações de usuário, de aluno, conteúdo teórico, recados e outras. Cada grupo de informação foi armazenado em uma tabela separada. A seguir são descritos e comentados os códigos de criação das tabelas na base de dados:

\section{Estrutura da tabela `USUARIO`}

\begin{tabular}{|c|c|}
\hline 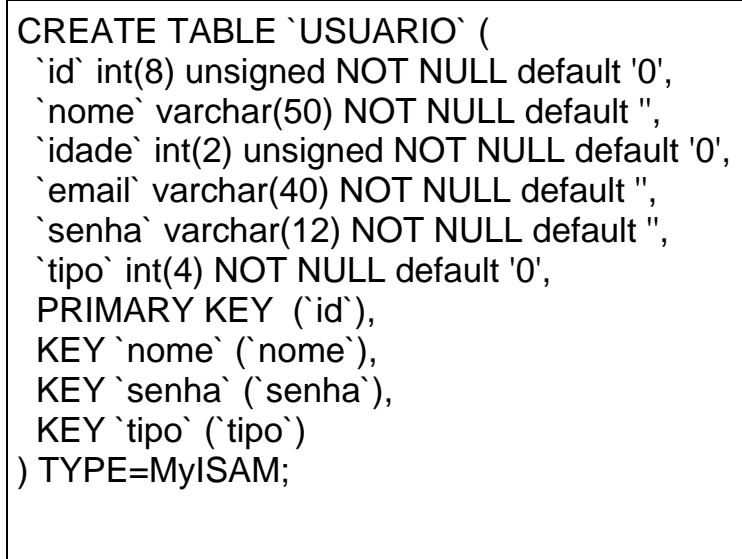 & $\begin{array}{l}\text { A tabela Usuário armazena os dados recebidos } \\
\text { pelo formulário de cadastro, em especial os } \\
\text { dados principais de identificação no sítio. "id" } \\
\text { corresponde à chave primária (neste caso o } \\
\text { número USP do usuário) e "tipo" define se o } \\
\text { usuário é aluno ou administrador (esse campo } \\
\text { pode assumir os valores } 1 \text { para administrador e } \\
0 \text { para aluno). }\end{array}$ \\
\hline
\end{tabular}




\section{Estrutura da tabela 'RECADO`}

CREATE TABLE `RECADO` (
'data` date NOT NULL default '0000-00-00',
'hora` time NOT NULL default '00:00:00',
'msg' varchar(255) NOT NULL default ",
'visivel int(4) NOT NULL default '0',
KEY 'data'('data'),
KEY 'hora' ('hora')
) TYPE=MyISAM;

A tabela Recado armazena os recados adicionados por algum administrador e exibidos na página de rosto do sítio. "visivel" representa a exibição ou não do recado (se o valor armazenado for 0 o recado não é exibido). Os outros campos armazenados são "data", "hora" e "mensagem" a ser veiculada.

\section{Estrutura da tabela `ALUNO`}

\begin{tabular}{|c|c|}
\hline 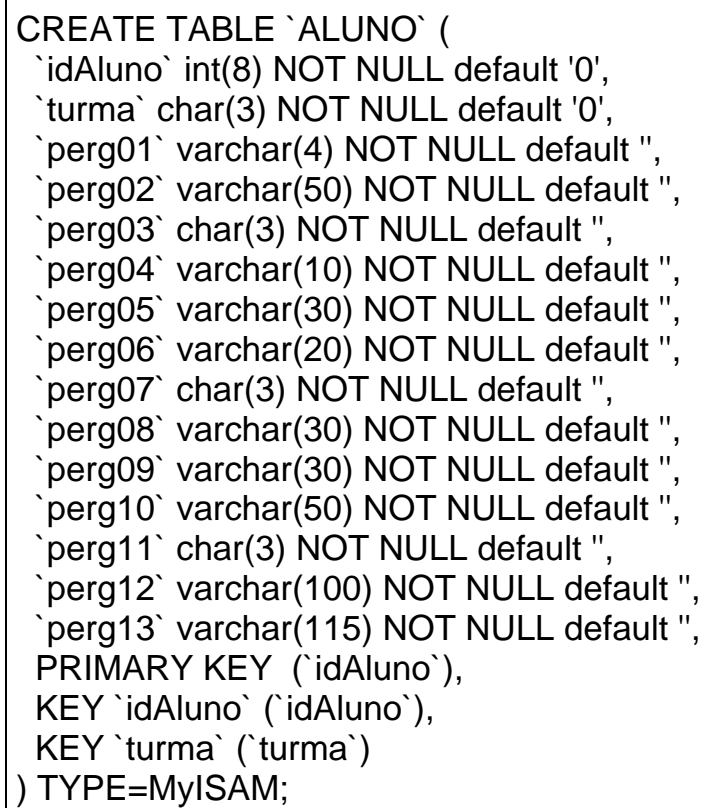 & $\begin{array}{l}\text { A tabela Aluno armazena também os dados } \\
\text { recebidos pelo formulário de cadastro, em } \\
\text { especial os dados das questões de } \\
\text { caracterização do aluno. "idAluno" } \\
\text { corresponde à chave primária (número USP do } \\
\text { usuário). Os campos "perg01" a "perg13" } \\
\text { armazenam as respostas fornecidas ao } \\
\text { questionário de caracterização. }\end{array}$ \\
\hline
\end{tabular}

\section{Estrutura da tabela 'CONTEUDO`}

\begin{tabular}{|c|c|}
\hline 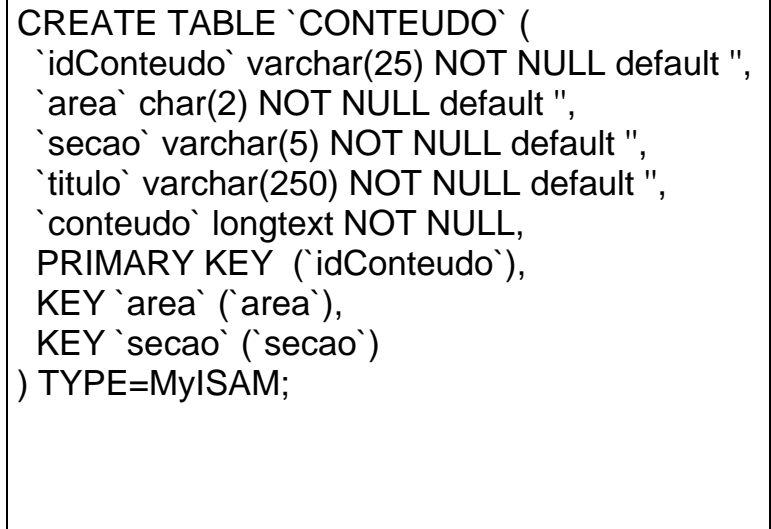 & $\begin{array}{l}\text { A tabela Conteúdo armazena o conteúdo } \\
\text { teórico adicionado à base (pela ferramenta } \\
\text { HTMLArea). "idConteudo" representa a chave } \\
\text { primária (que localiza o conteúdo desejado); } \\
\text { "area" representa a área de conhecimento a que } \\
\text { o conteúdo pertence (Algarismos } \\
\text { Significativos, Análise Gravimétrica ou } \\
\text { Volumétrica), "seção" armazena a numeração } \\
\text { do tópico, "titulo" armazena o título do tópico } \\
\text { em questão e "conteudo" armazena o conteúdo } \\
\text { já formatado. }\end{array}$ \\
\hline
\end{tabular}




\section{Estrutura da tabela 'GLOSSARIO`}

\begin{tabular}{|c|c|}
\hline 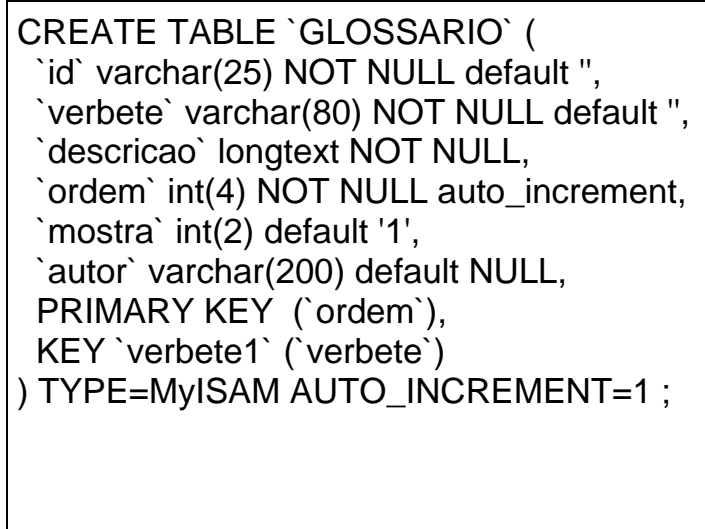 & $\begin{array}{l}\text { A tabela Glossário armazena termos de } \\
\text { glossário inseridos para um determinado } \\
\text { conteúdo. "id" representa a chave primária, } \\
\text { "verbete" armazena o termo em questão, } \\
\text { "descricao" armazena a descrição do termo, } \\
\text { "ordem" armazena a chave primária do } \\
\text { conteúdo ao qual o termo está vinculado, } \\
\text { "mostra" representa a exibição ou não do termo } \\
\text { (se o valor armazenado for 0, o termo não é } \\
\text { exibido no sítio), "autor" armazena o nome do } \\
\text { usuário que inseriu o termo. }\end{array}$ \\
\hline
\end{tabular}

\section{Estrutura da tabela 'LINK`}

\begin{tabular}{|c|c|}
\hline 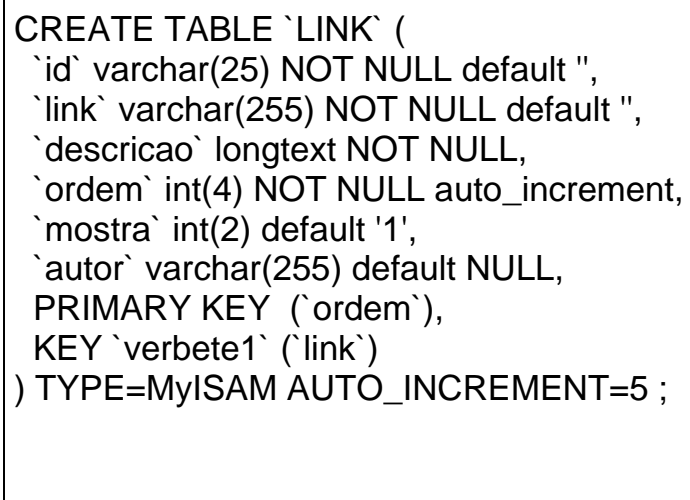 & $\begin{array}{l}\text { A tabela Link armazena links relacionados } \\
\text { inseridos para um determinado conteúdo. "id" } \\
\text { representa a chave primária, "link" armazena a } \\
\text { URL em questão (link), "descrição" armazena } \\
\text { um comentário sobre o link, "ordem" armazena } \\
\text { a chave primária do conteúdo ao qual o link } \\
\text { está vinculado, "mostra" representa a exibição } \\
\text { ou não do link (se o valor armazenado for 0, o } \\
\text { link não é exibido no sítio), "autor" armazena o } \\
\text { nome do usuário que inseriu o link. }\end{array}$ \\
\hline
\end{tabular}

\section{Estrutura da tabela 'RELATORIO`}

\begin{tabular}{|c|c|}
\hline 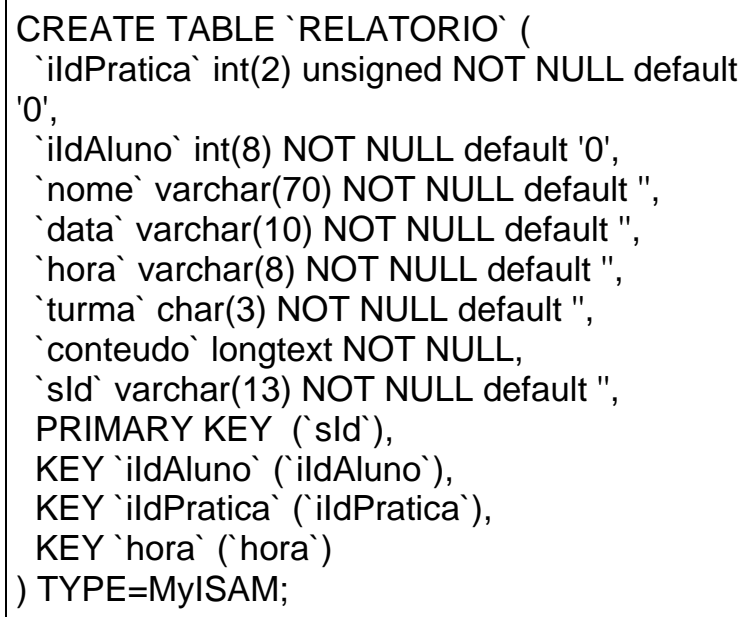 & $\begin{array}{l}\text { A tabela Relatório armazena os relatórios } \\
\text { semanais enviados pelos alunos. A tabela } \\
\text { armazena a prática ("iIdPratica") a que o } \\
\text { relatório se refere, o numero USP do aluno } \\
\text { ("iIdAluno"), seu nome, data, hora, turma a } \\
\text { que pertence, o conteúdo do relatório e a chave } \\
\text { primária do relatório (necessária para } \\
\text { selecionar um relatório específico). }\end{array}$ \\
\hline
\end{tabular}




\section{Estrutura da tabela 'TRACK}

\begin{tabular}{|c|c|}
\hline $\begin{array}{l}\text { CREATE TABLE 'TRACK` ( } \\
\text { “idTrack` varchar(15) NOT NULL default ", } \\
\text { 'nome` varchar(50) NOT NULL default ", } \\
\text { 'idConteudo`varchar(15) NOT NULL default ", } \\
\text { 'data`varchar(50) NOT NULL default ", } \\
\text { PRIMARY KEY ("idTrack'), } \\
\text { KEY `nome` ('nome'), } \\
\text { KEY 'data`("data') } \\
\text { ) TYPE=MyISAM; }\end{array}$ & $\begin{array}{l}\text { A tabela Track armazena as informações de } \\
\text { navegação dos alunos. Armazena em ordem } \\
\text { cronológica a chave primária "idTrack", o } \\
\text { nome do aluno, a página visitada } \\
\text { "idConteudo", a data e a hora da visita. }\end{array}$ \\
\hline
\end{tabular}

\section{Estrutura da tabela `AVALIAÇÃO’}

\begin{tabular}{|c|c|}
\hline 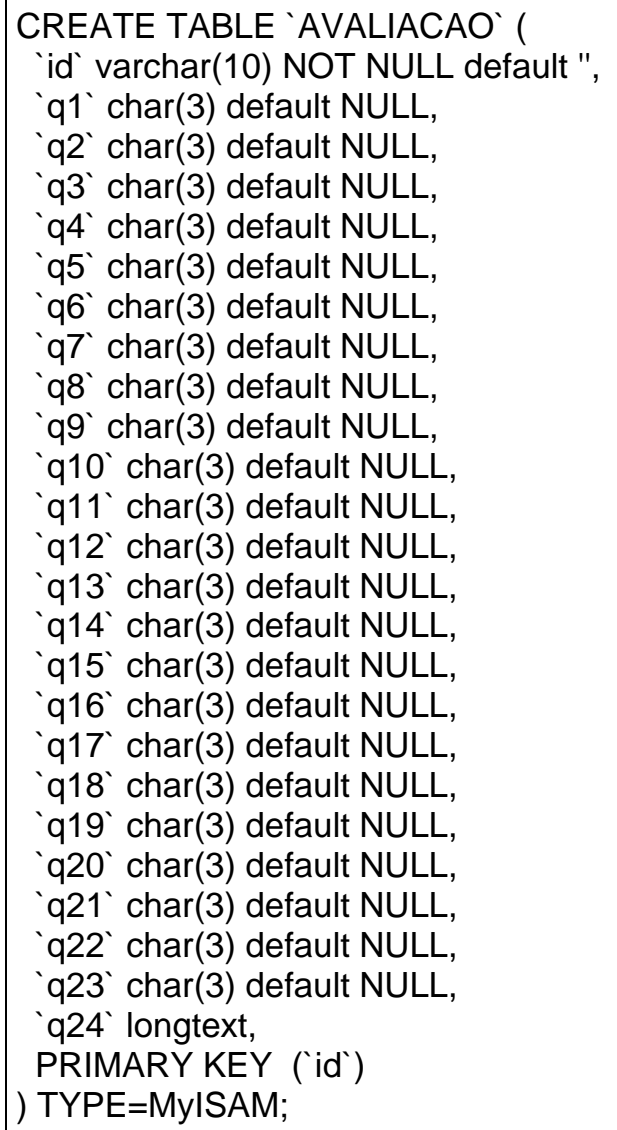 & $\begin{array}{l}\text { A tabela Avaliação armazena as informações } \\
\text { do questionário de avaliação do sítio. "id" } \\
\text { corresponde ao número USP do aluno, e "q1" } \\
\text { a "q24" correspondem às respostas fornecidas } \\
\text { a cada uma das questões do questionário. }\end{array}$ \\
\hline
\end{tabular}

Todas as tabelas citadas acima foram criadas diretamente na base de dados (pelo código descrito acima) utilizando a ferramenta de gerenciamento PHPMyAdmin. No entanto, a inserção, seleção e remoção dos dados são gerenciadas pelas páginas da camada Modelo da aplicação. 


\subsection{Definição do projeto de navegação e funcionalidades do sítio}

Conforme mencionamos anteriormente, todos os alunos interessados no uso da aplicação precisaram se cadastrar antes do primeiro acesso. Para tanto, os alunos acessaram a página de entrada no sistema no endereço http://www.qa-online.locaweb.com.br. A página de acesso exibe apenas o formulário de autenticação e o link para a página de cadastro representada pela Figura 7.

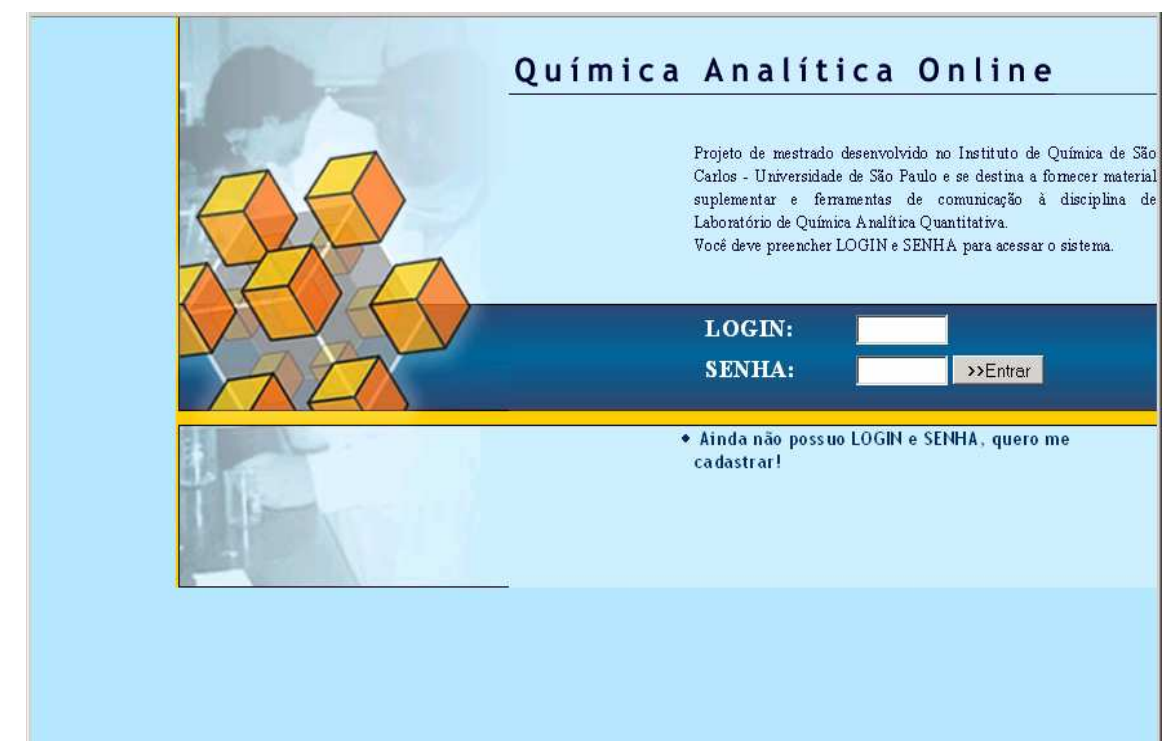

Figura 7: Página de acesso ao sistema, com o formulário de autenticação e link para o cadastro do aluno. Após o login do aluno, são criadas variáveis de sessão (variáveis disponíveis a qualquer momento, enquanto o usuário estiver ativo no sítio), para identificação do usuário, e correspondem ao nome, senha e tipo de usuário. 
Para a autenticação do usuário, esta página envia o login e a senha inseridos no formulário, para a página loginAction.jsp (Quadro 5), que seleciona a tabela USUARIO, verifica a existência do cadastro na tabela, e redireciona à página correta. Caso o nome de usuário e senha existam, o internauta é redirecionado para a página de rosto que verifica então se é aluno ou administrador.

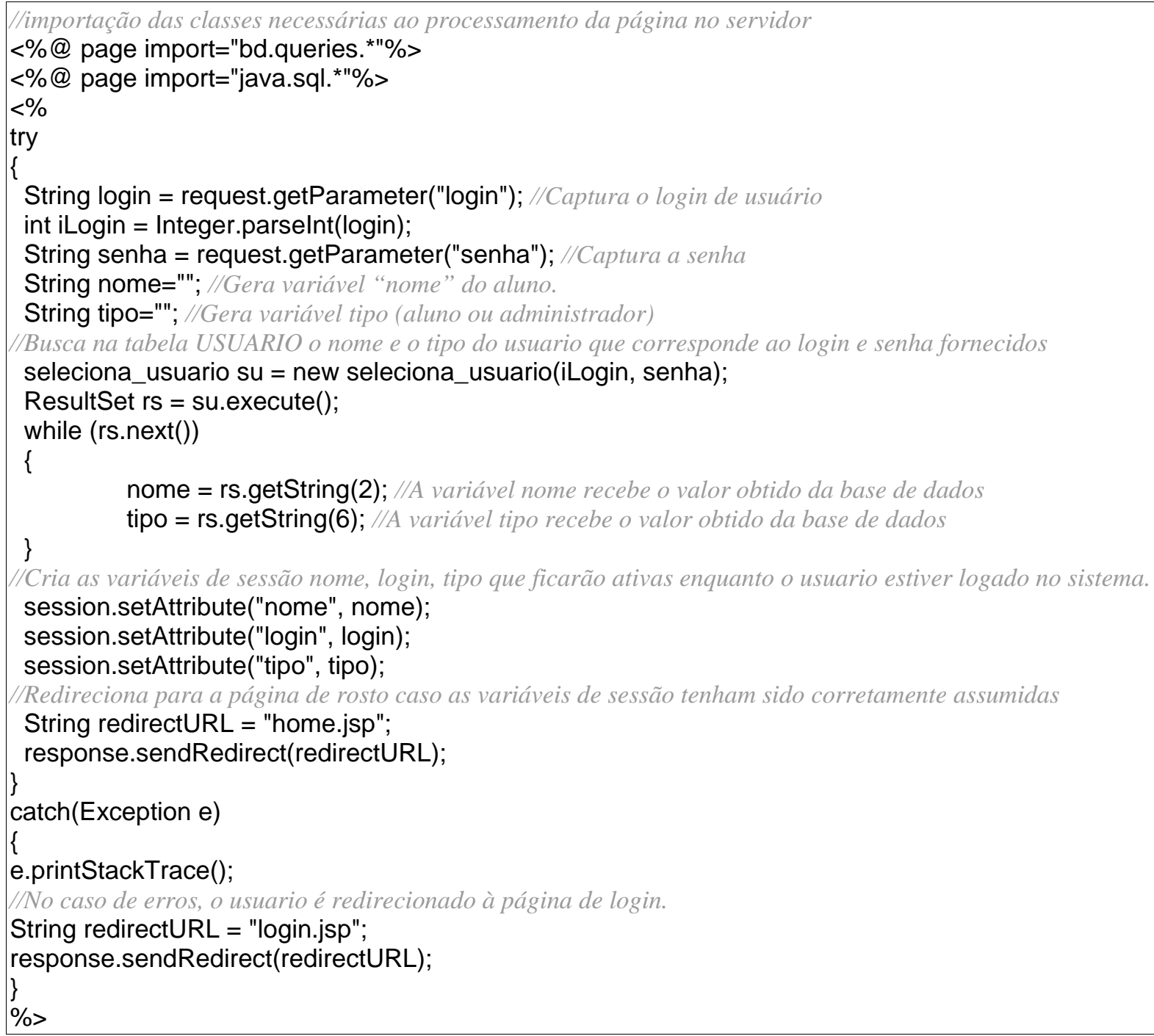

Quadro 5: Código-fonte da página loginAction.jsp, que verifica o cadastro do usuário, e redireciona à página de rosto do administrador ou do aluno.

Caso o internauta não tenha acesso ao sítio, ele pode realizar o cadastro como aluno matriculado na disciplina. Este cadastro tem a finalidade de identificar o aluno e suas atividades no sítio. A página de cadastro, exibida na Figura 8, captura as seguintes 
informações no ato de inscrição: nome completo, idade, e-mail, número USP (login), senha, ano de ingresso na USP, turma a que pertence (Turma 1 ou Turma 2). Além destas informações, o questionário de caracterização do aluno também é exibido nesta página.

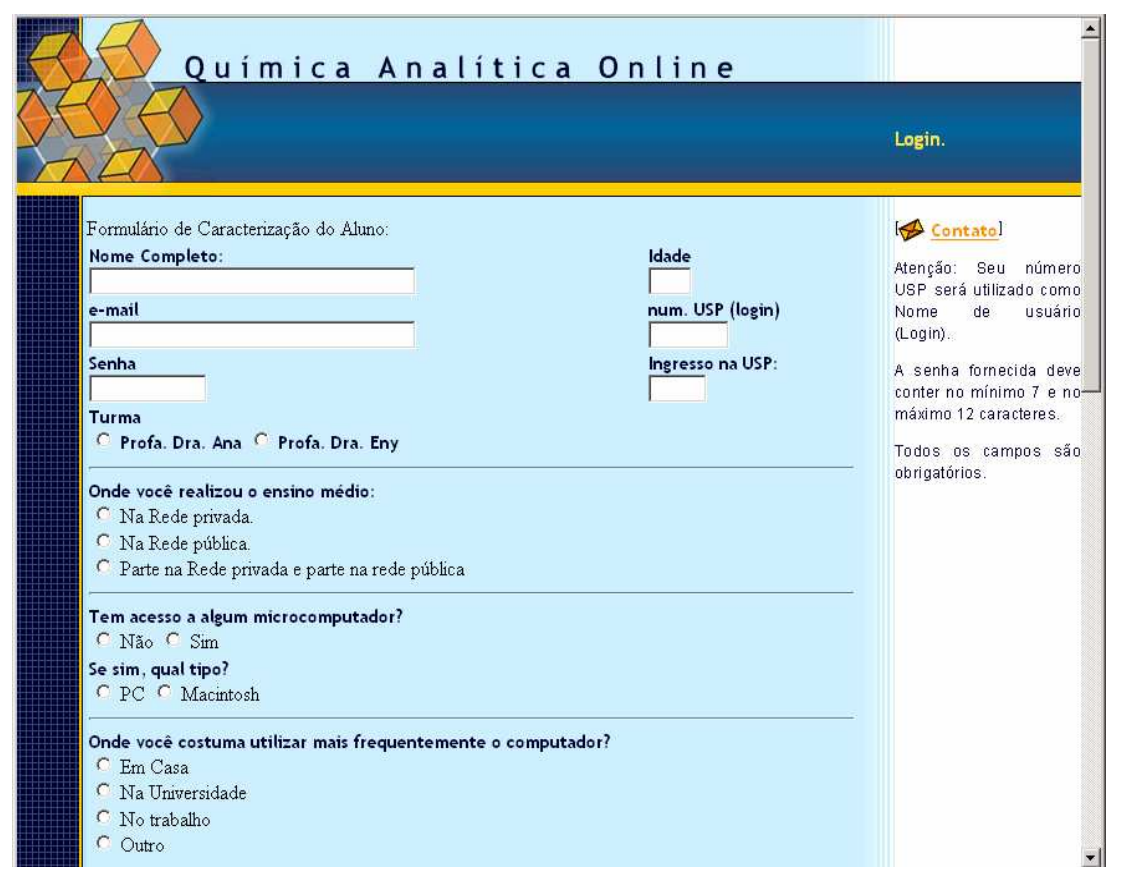

Figura 8: Página de cadastro no sistema, e formulário de caracterização do aluno, sugerindo um formulário único. 
Após o envio, os dados são recebidos pela página CadastroAlunoAction.jsp. Esta página recebe os dados e os organiza em variáveis para que as classes "insere_usuario.class" e "insere_aluno.class" (armazenadas na pasta WEB-INF/CLASSES/BD/QUERIES) possam inserir as informações do usuário na tabela USUÁRIO da base de dados, e as informações do questionário de caracterização na tabela ALUNO. O código-fonte da página CadastroAlunoAction.jsp é reproduzido no Quadro 6.

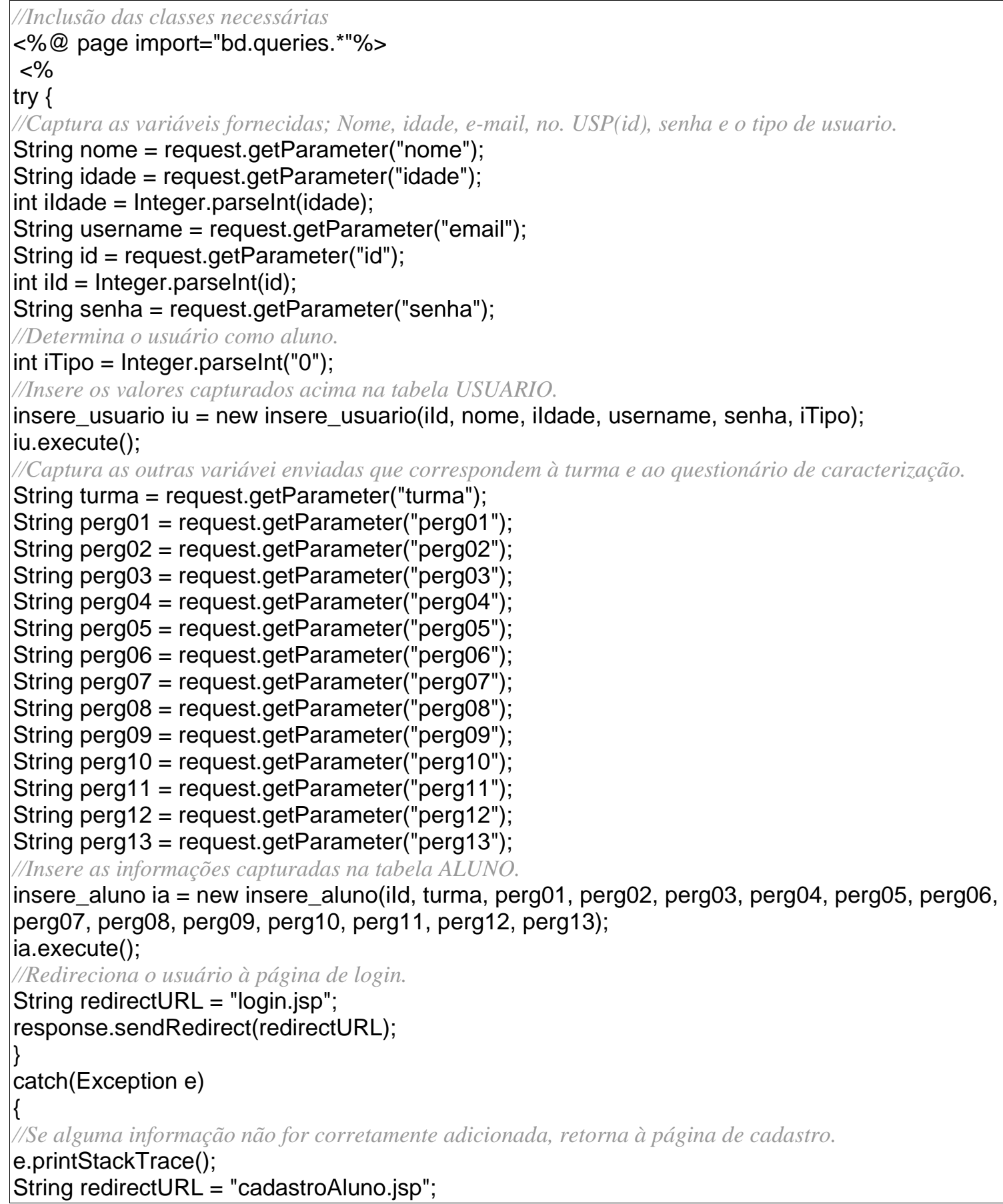


response.sendRedirect(redirectURL);

\}

$\%>$

Quadro 6: Código-fonte da página CadastroAlunoAction.jsp, responsável por inserir os dados do usuário nas tabelas ALUNO e USUARIO do sistema.

Como é possivel perceber, a página CadastroAlunoAction.jsp utiliza duas classes Java: as classes "insere_usuario.class" e "insere_aluno.class", que inserem as informações em suas respectivas tabelas na base de dados. Como explicado anteriormente, as classes provêm da compilação dos arquivos .JAVA armazenados na pasta SRC do sistema. O código-fonte das classes citadas é reproduzido nos Quadros 7 e 8.

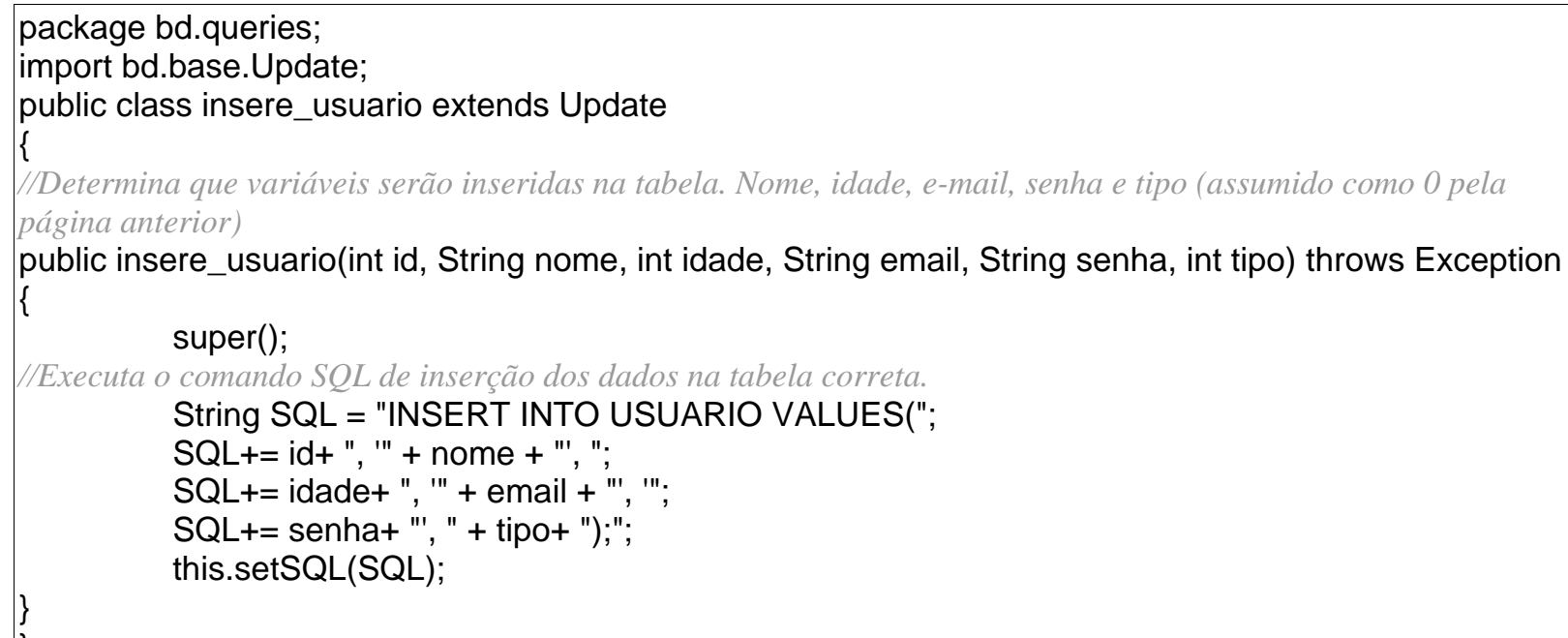

Quadro 7: Código-fonte da classe "insere_usuario.class", responsável por inserir os dados do usuário nas tabela USUARIO do sistema. Este código representa o arquivo "insere_usuário.java" na pasta WEB-INF/BD/SRC. 


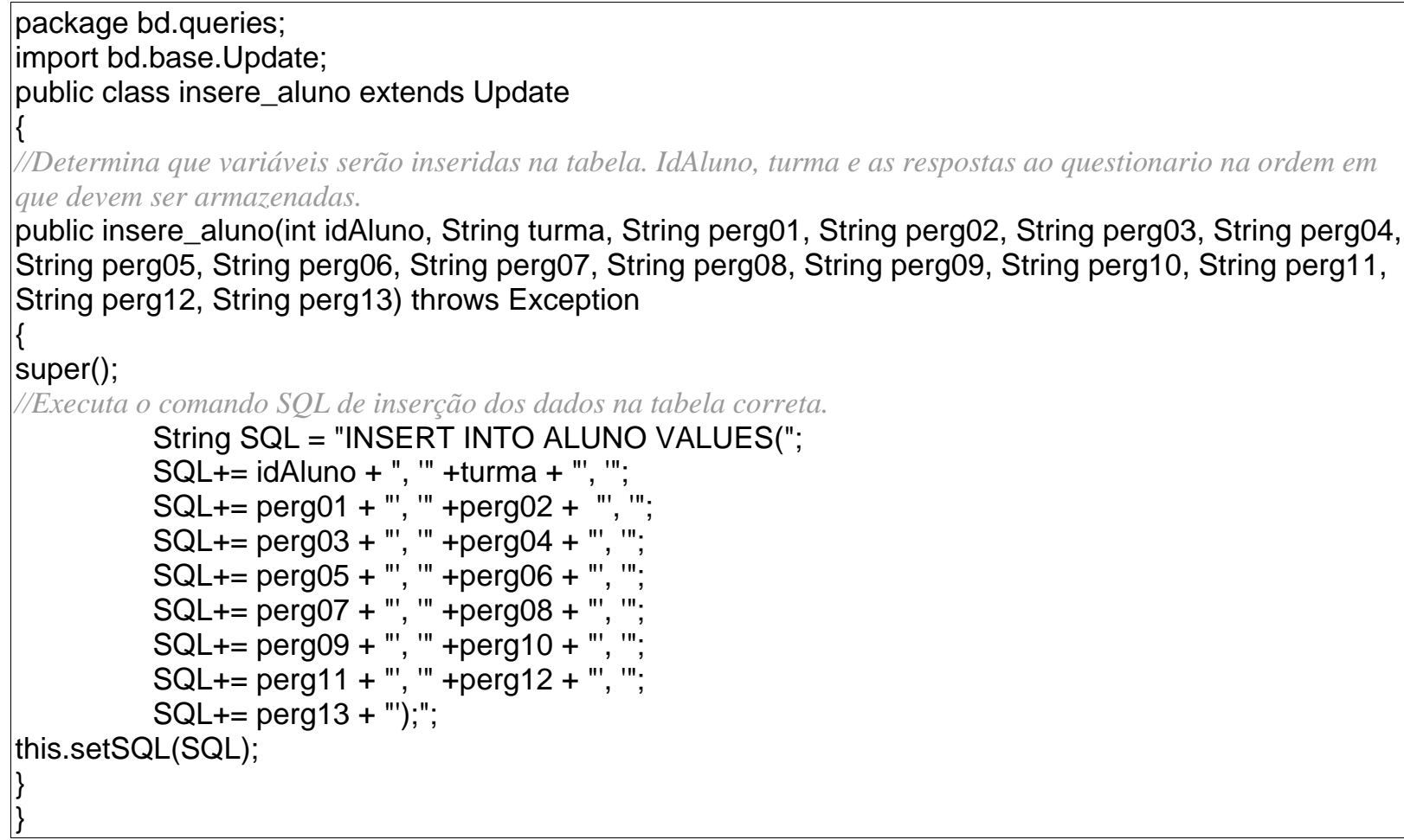

Quadro 8: Código-fonte da classe "insere_aluno.class", responsável por inserir os dados do questionário de caracterização na tabela ALUNO do sistema. Este código representa o arquivo "insere_aluno.java" na pasta WEB-INF/BD/SRC.

\subsection{Mapa de navegação}

Após o cadastro o usuário pode acessar a aplicação fornecendo Nome de Usuário e Senha. Cada usuário foi classificado como aluno ou administrador (neste caso apenas docentes ou estagiários), dividindo a aplicação em dois módulos distintos. O mapa de navegação do sítio pode ser representado pela Figura 9. Os detalhes da programação e funcionalidades de cada página serão descritos nos tópicos subseqüentes: 


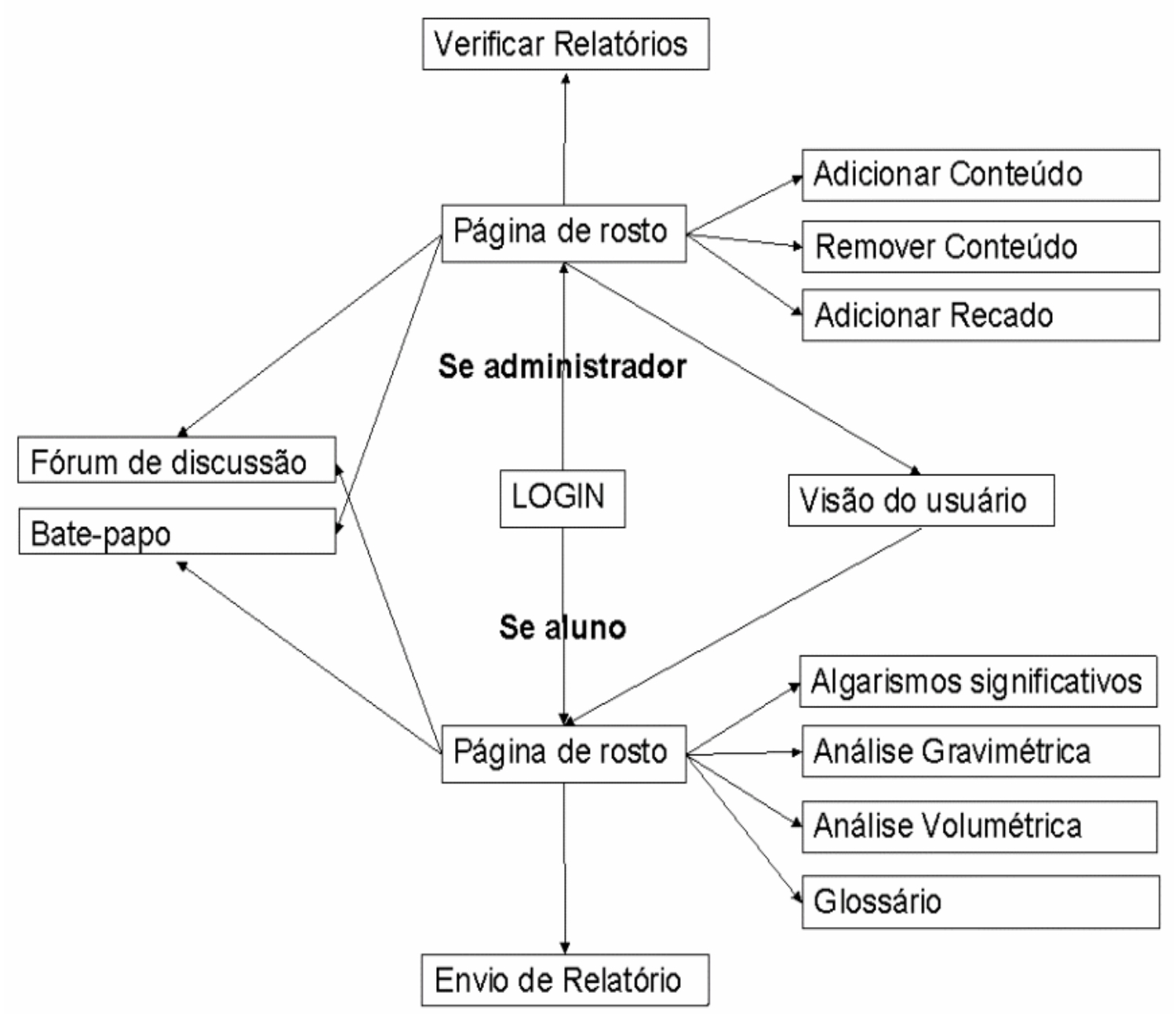

Figura 9: Diagrama esquemático da navegação no sítio para ambos os módulos, administrador e aluno.

Após o login, o sistema determina o tipo de usuário e redireciona à página de Rosto, com os links relativos ao tipo do usuário (conforme o mapa da navegação). Caso o usuário seja um administrador, suas possibilidades são adicionar ou remover conteúdo teórico à base de dados, adicionar recados para exibição na página de rosto, verificar os relatórios enviados pelos alunos, acessar o bate-papo e o fórum de discussão, ou ainda visualizar o sítio como aluno cadastrado. No caso de acesso por um aluno, suas possibilidades são a de acessar uma das 3 áreas de leitura ou o glossário relacionado, enviar relatório, acessar o bate-papo e o fórum. Interessante salientar que a página de rosto exibida tanto para administradores quanto para alunos é a mesma, diferenciando apenas a barra superior que exibe os links específicos 
para cada tipo de usuário identificado pelo sistema. Apenas a zona principal das páginas em questão será comentada nos próximos tópicos visto que os outros elementos da página seguem as regras definidas no projeto do sítio.

\subsubsection{Página de Rosto}

Após o acesso ao sistema, a primeira página a ser exibida é a página de Rosto, que exibe as notícias da disciplina, adicionadas por algum dos administradores, em ordem cronológica inversa como mostra a Figura 10.

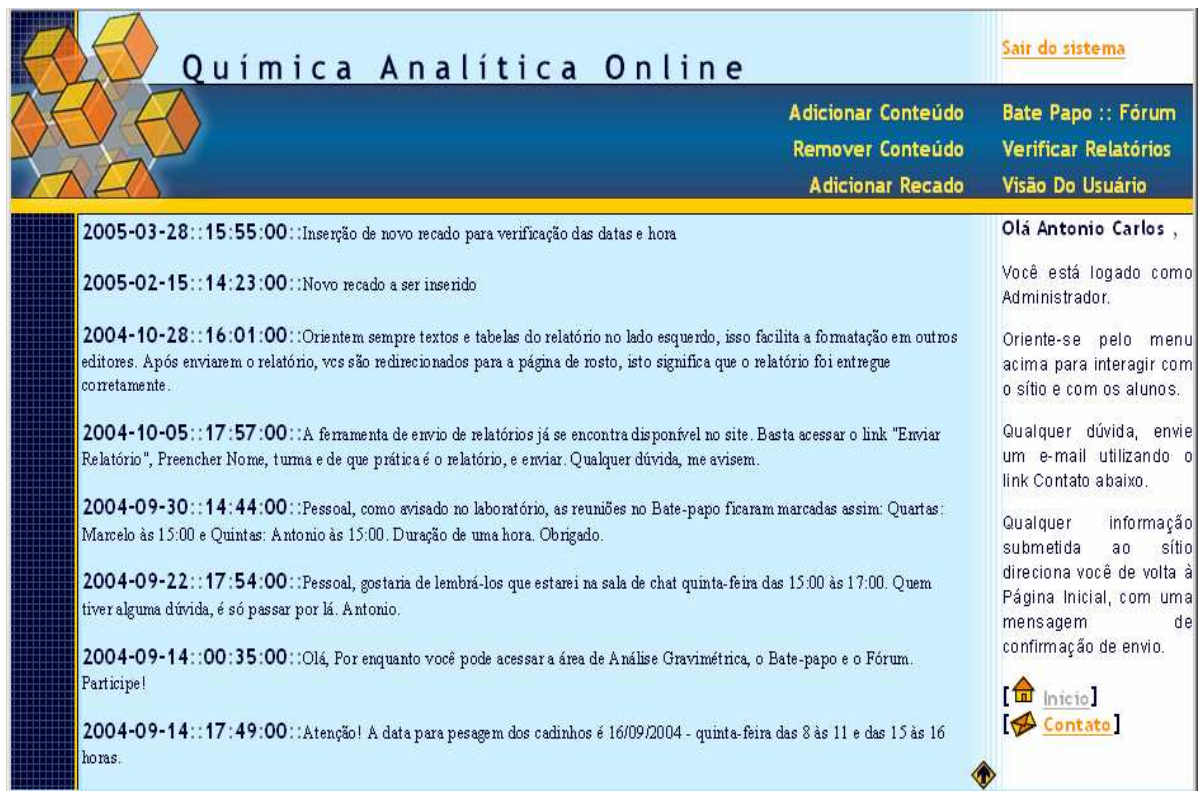

Figura 10: Página de Rosto do sistema no módulo administrador. A zona principal da página é a que contém as notícias exibidas no formato data:hora:notícia, em ordem cronológica inversa.

As notícias exibidas na zona principal da página são obtidas da base de dados pelo scriptlet do Quadro 9 que é inserido diretamente no código HTML.

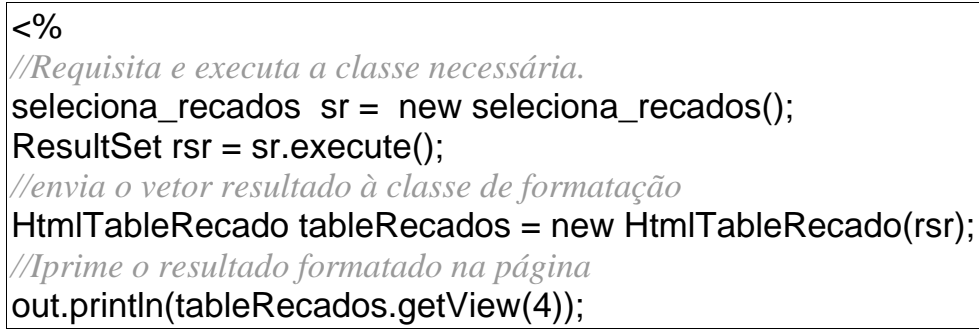


$\%>$

Quadro 9: Scriptlet usado na página de rosto (em ambos os módulos).

O comando seleciona_recados é na realidade a chamada para a classe “seleciona_recados.class" armazenada na pasta WEB-INF/CLASSES/BD/QUERIES da aplicação. Seu código fonte (seleciona_recados.java) é transcrito e comentado no Quadro 10.

package bd.queries;

import bd.base.SQLQuery;

public class seleciona_recados extends SQLQuery

\{

public seleciona recados() throws Exception

\{

/Executa o comando SQL que seleciona TODAS as informações da tabela RECADO e ordena por "data" em ordem descendente.

String query = "SELECT * FROM RECADO";

query += " ORDER BY data DESC;";

this.setSQL(query);

\}

\}

Quadro 10: Código-fonte da classe "seleciona_recados".

Os valores retornados pelo vetor (query) são armazenados em um vetor resultado (ResultSet) na classe "HtmlTableRecado.class" cujo código é transcrito no Quadro 11:

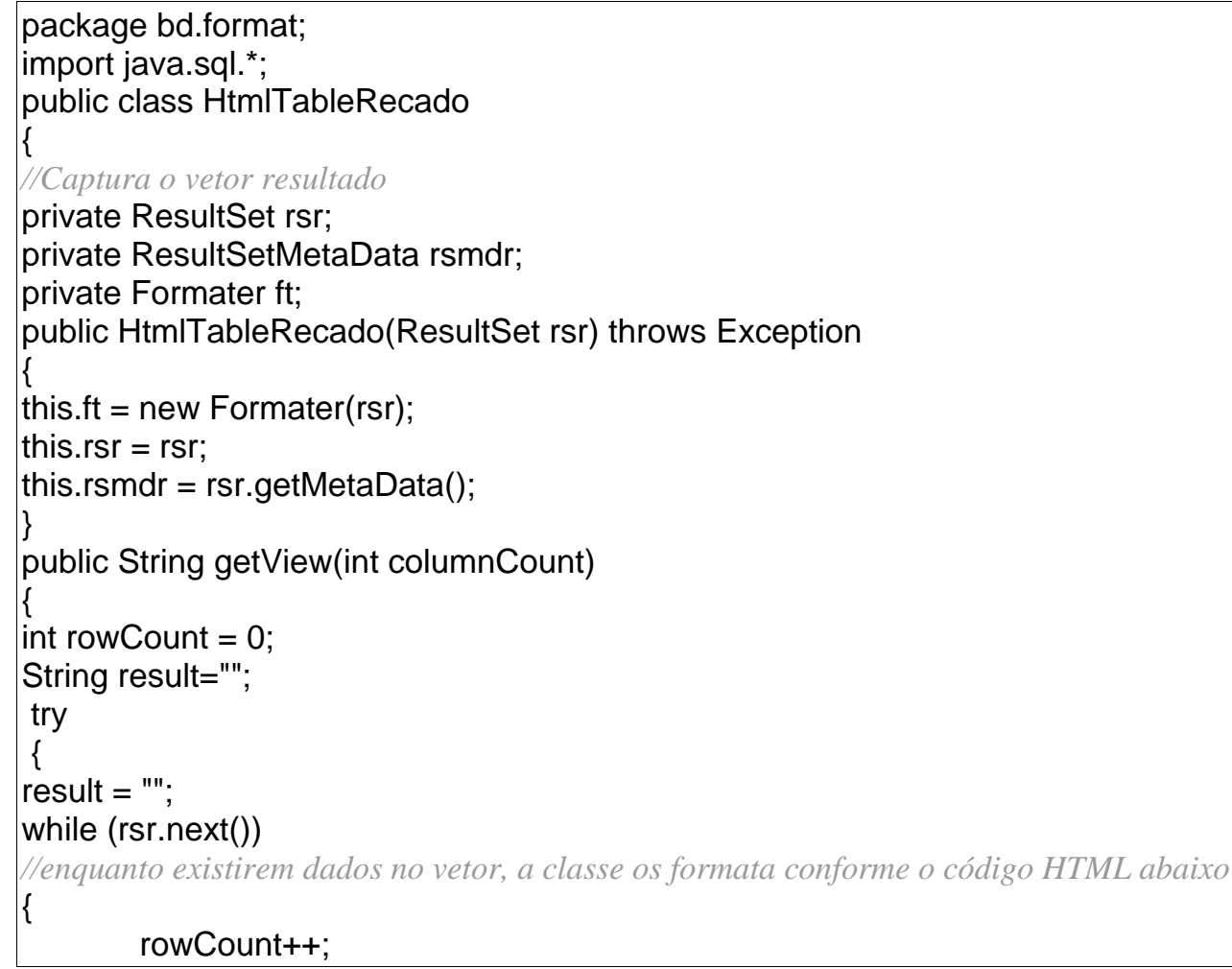




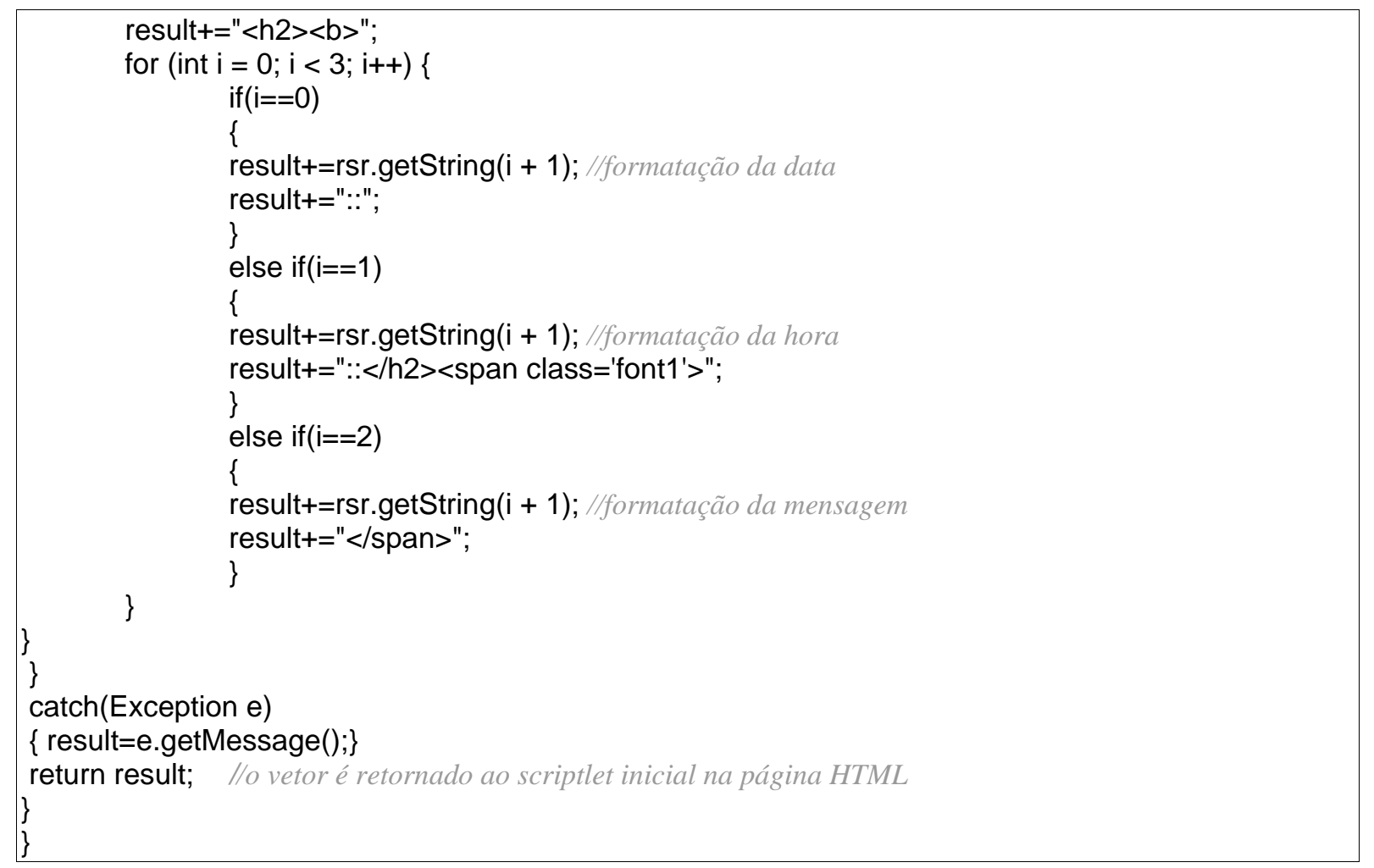

Quadro 11: Código-fonte da classe "HtmlTableRecado".

A classe "HtmlTableRecado" lê o vetor resultado e separa os valores em data, hora e mensagem. Uma variável chamada Result é criada e o código HTML é gerado dentro desta variável, formatando a data e hora de inserção e o recado adicionado. A classe repete a formatação a todos os recados inseridos na base e o código HTML final é impresso no navegador.

\subsubsection{Página Adicionar Conteúdo}

A página Adicionar Conteúdo possui em sua zona principal um formulário para adição do conteúdo à base de dados como representado na Figura 11. O administrador deve definir a que área se destina o tópico a ser inserido, qual será sua numeração (dentro da área escolhida) e o título do tópico. A inserção do conteúdo teórico é feita utilizando uma ferramenta gratuita escrita em Javascript chamada HTMLArea ${ }^{74}$. Esta ferramenta permite a inserção de conteúdo formatado em uma caixa de texto; assim o administrador adiciona 
conteúdo diretamente à base de dados como se estivesse utilizando um software de edição de texto (como o Microsoft Word ${ }^{\mathrm{TM}}$ por exemplo).

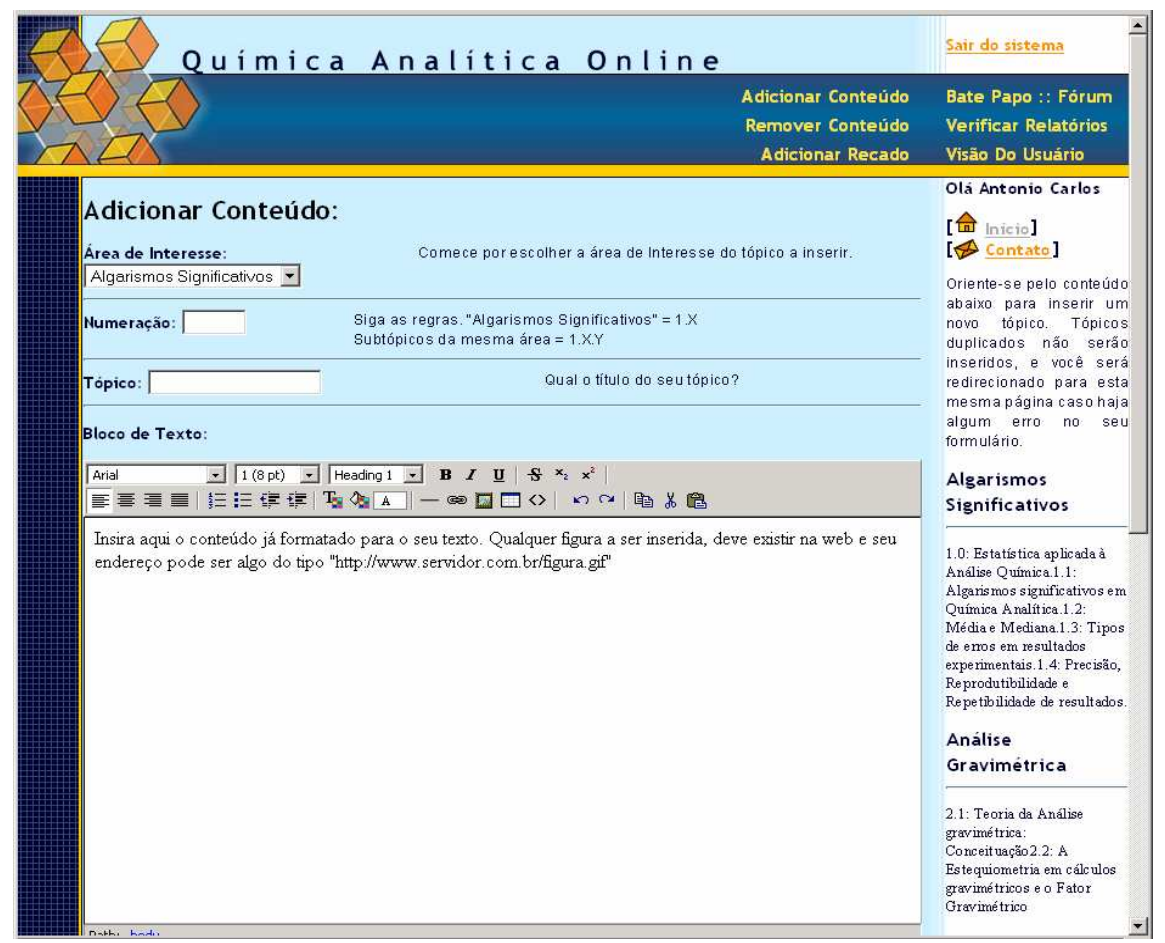

Figura 11: Representação da página de inserção de conteúdo. A caixa de texto principal é na realidade a ferramenta HTMLArea ${ }^{74}$, um código javascript que permite escrever textos formatados diretamente de uma página Web. É interessante notar que a barra lateral exibe os tópicos já adicionados à base para que o administrador não adicione tópicos repetidos ou numeração repetida, fato que anularia toda a operação.

Esta página trata da inserção e não da seleção de informação, assim sua lógica é diferente. Ao clicar no botão "Adicionar Conteúdo", as informações são enviadas à página InsereConteudoAction.jsp transcrita no Quadro 12.

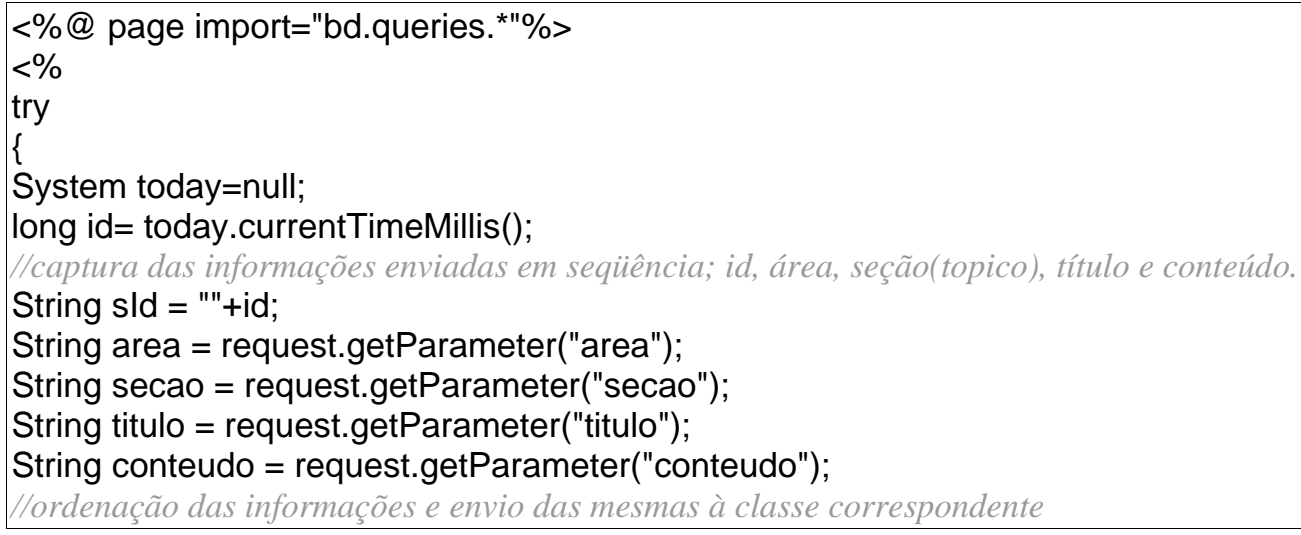




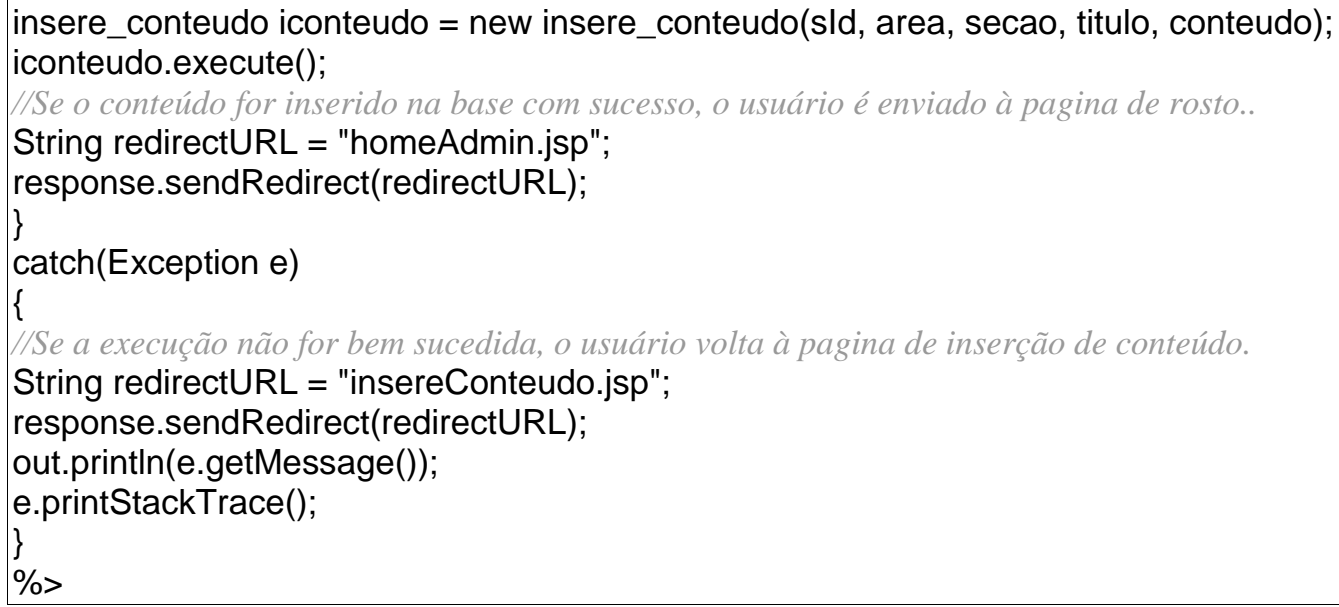

Quadro 12: Código-fonte da página insereConteudoAction.jsp

Esta página recebe as informações enviadas e gera as variáveis correspondentes (sId, área, seção, título e conteúdo). Estas variáveis são então enviadas à classe “insere_conteudo.class", que executa a inserção das informações recebidas nos respectivos campos da base de dados. O código fonte da classe "insere_conteudo" é reproduzido e comentado no Quadro 13.

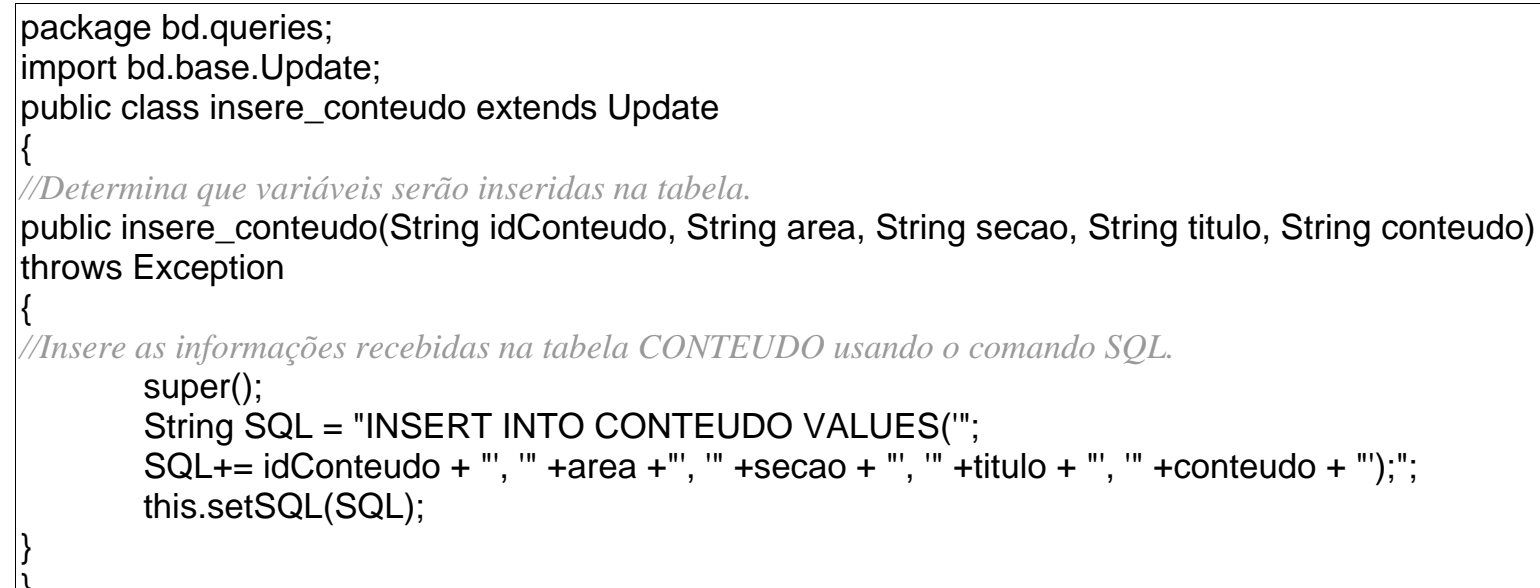

Quadro 13: Código-fonte da classe “insere_conteudo".

\subsubsection{Página Remover Conteúdo}

A página Remover Conteúdo permite a um administrador remover da base de dados um determinado tópico. Para tanto, no acesso a esta página, um scriptlet seleciona cada um dos tópicos das 3 áreas existentes (Algarismos Significativos, Análise Gravimétrica e Análise 
Volumétrica) e os exibe na página antecedidos de um marcador como mostrado na Figura 12.

O administrador deve então escolher o tópico a remover e submeter o pedido.

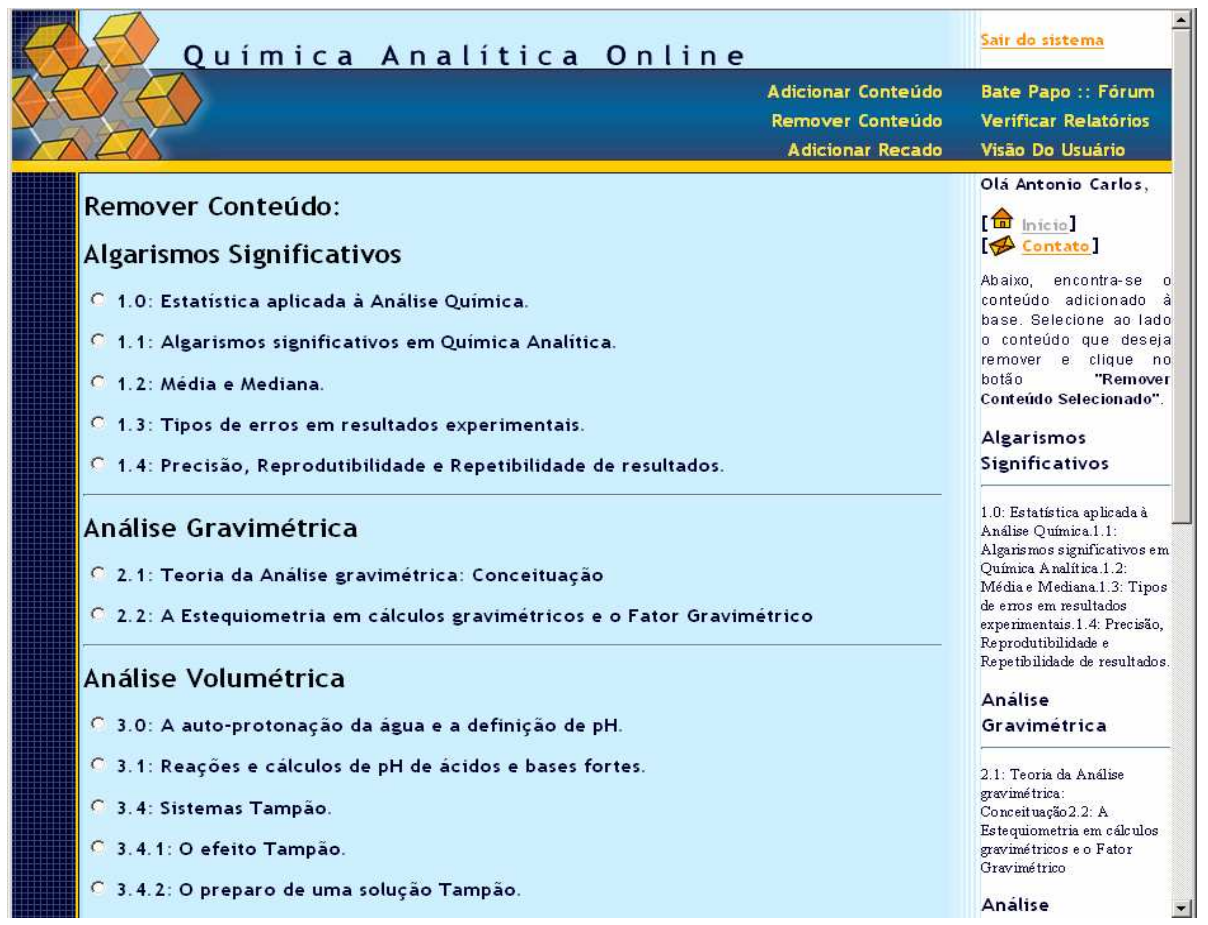

Figura 12: Página de remoção de conteúdo. Os tópicos existentes na base são listados tanto na zona principal quanto na barra lateral do sítio. O administrador deve selecionar o conteúdo a remover e clicar no botão remover conteúdo no fim da página.

O scriptlet geral de seleção e formatação deste conteúdo é mostrado no Quadro 14. Reproduzimos apenas o scriptlet para o conteúdo 1, visto que para qualquer outro, o único valor variável é a área especificada para seleção (1, 2 ou 3).

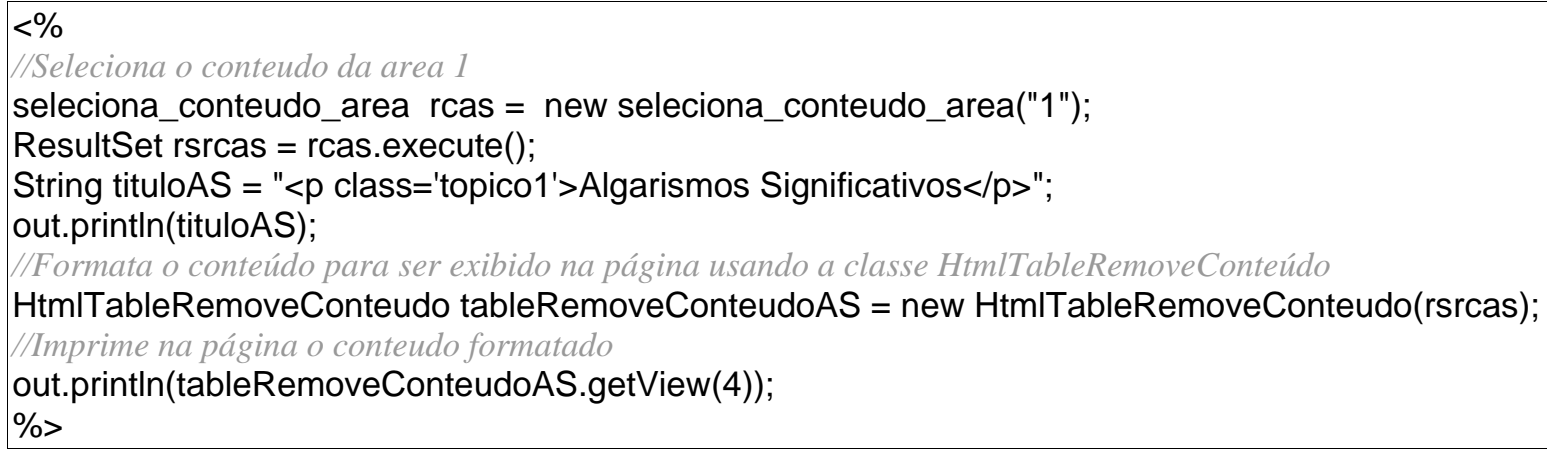

Quadro 14: Scriptlet de remoção do conteúdo teórico. 
As três requisições na realidade executam a classe "seleciona_conteudo_area.class", que acessa a base de dados e retorna todo o conteúdo de uma determinada área escolhida. $\mathrm{O}$ código-fonte desta classe é representado no Quadro 15. Este resultado é então enviado à classe "HtmlTableRemoveConteudo.class" (Quadro 16), que ordena e formata os tópicos da forma como devem ser visualizados no navegador produzindo o resultado visto na Figura 12.

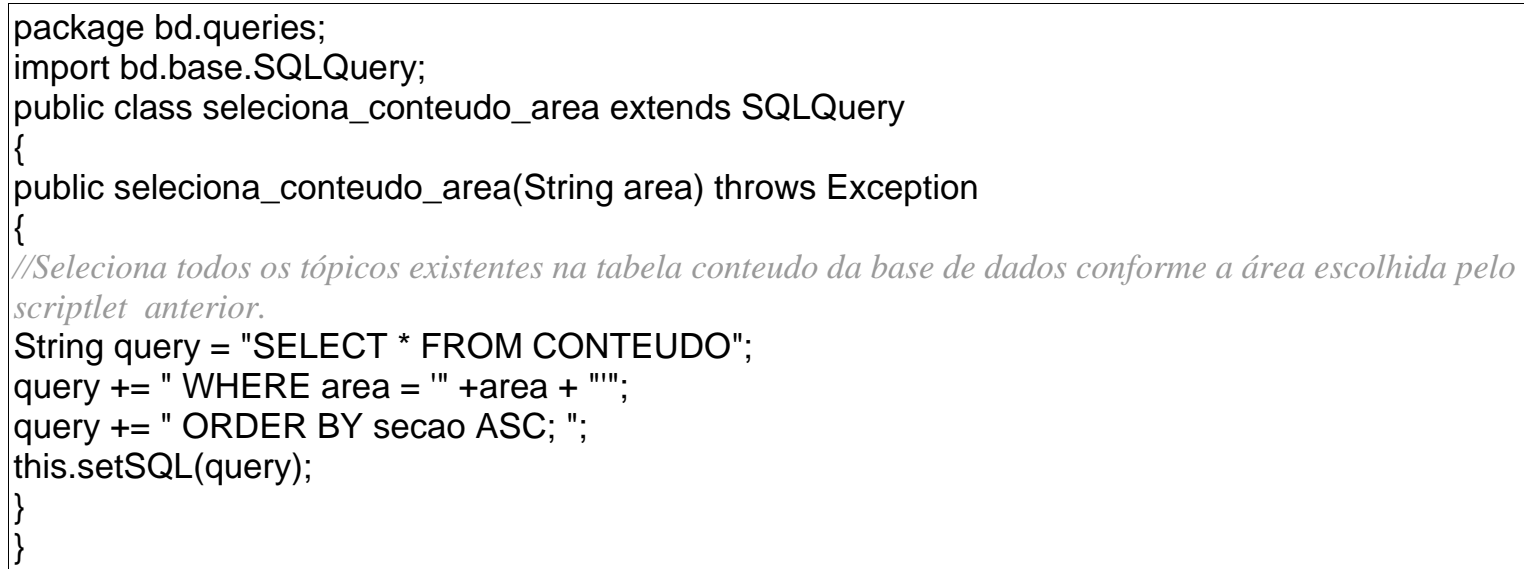

Quadro 15: Código-fonte para a classe "seleciona_conteudo_area.class".

Esta classe seleciona todos os campos da tabela CONTEUDO, onde a área corresponda à área selecionada (1, 2 ou 3), e ordena por seção de forma ascendente. Os valores retornados são armazenados em um vetor resultado (QUERY) e enviados à classe “HtmlTableRemoveConteudo" cujo código é transcrito no Quadro 16.

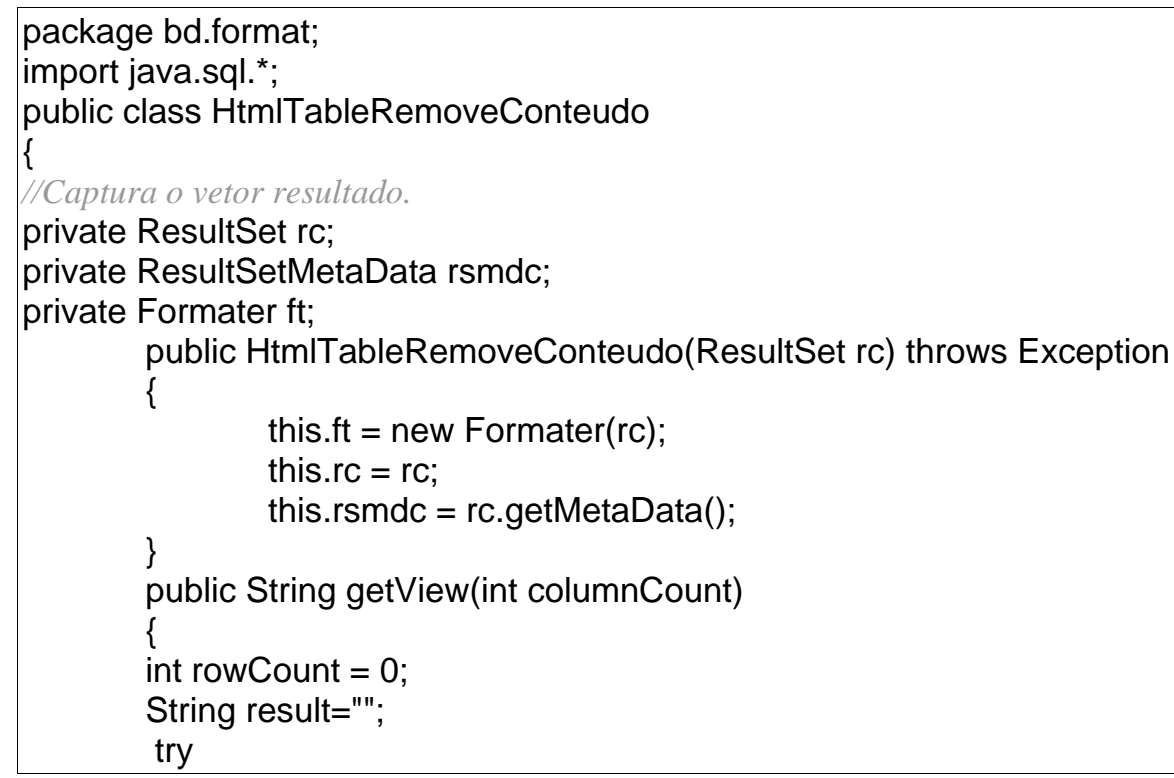




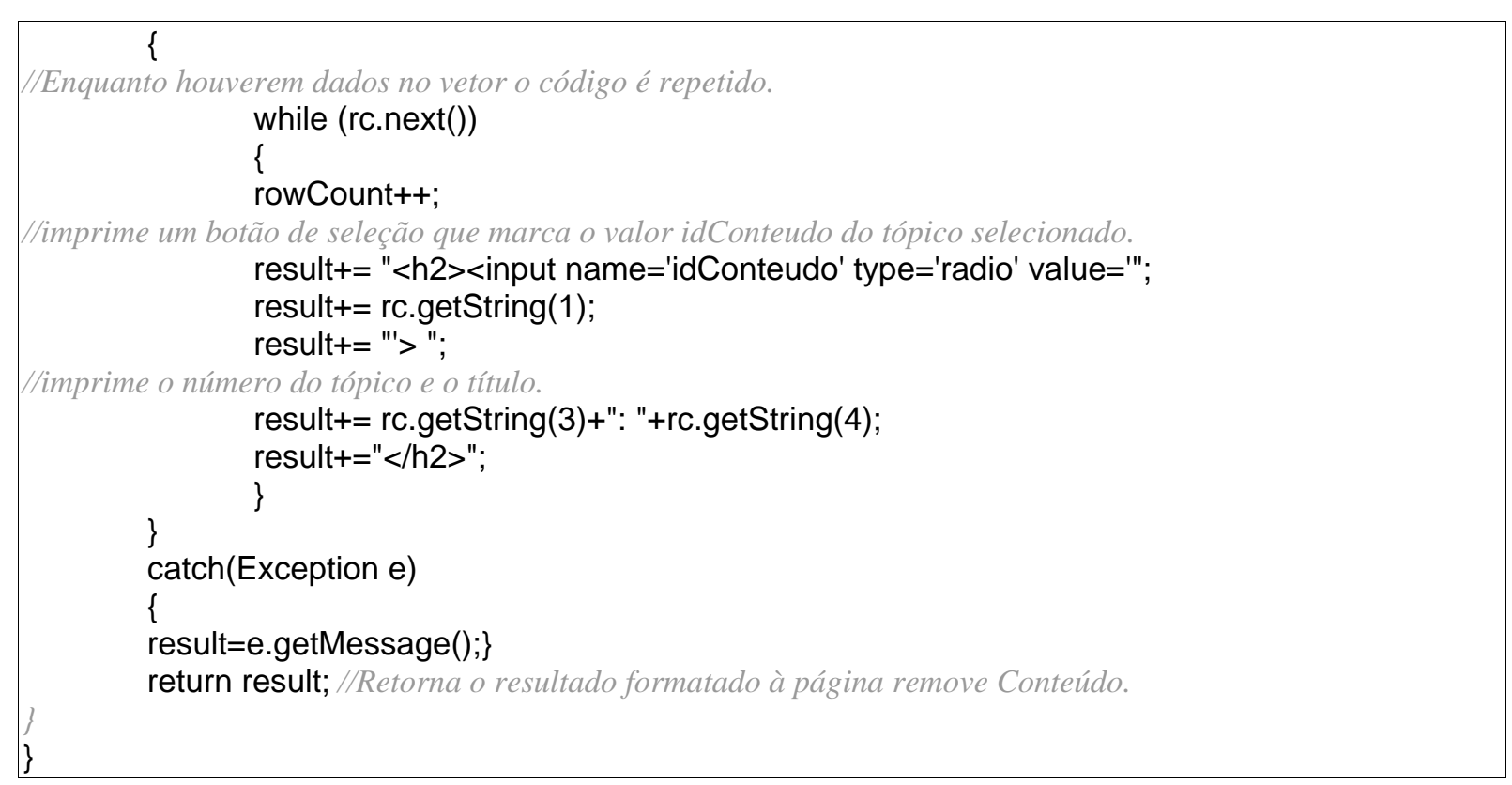

Quadro 16: Código-fonte para a classe "HtmlTableRemoveConteudo".

\subsubsection{Página Adicionar Recado}

A página Adicionar Recado possui em sua zona principal um formulário simples para adição de recados à base de dados como na Figura 13.

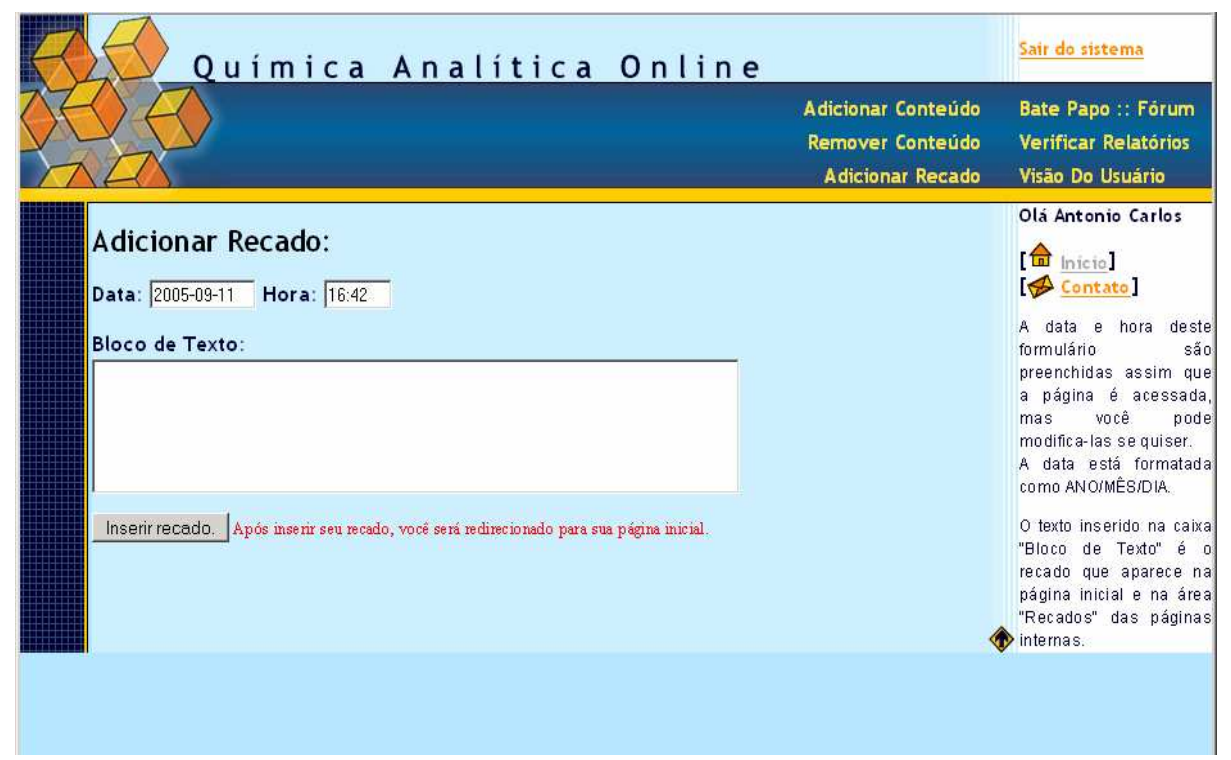

Figura 13: Representação da página InsereRecado.jsp 
O formulário é composto de três campos: Data e hora são preenchidos automaticamente por um código javascript inserido na página. $\mathrm{O}$ administrador pode modificar data e hora da inserção do recado e depois preencher o recado que será veiculado na página de rosto do sítio. Ao clicar no botão "inserir", os dados são enviados à página insereRecadoAction.jsp transcrita no Quadro 17.

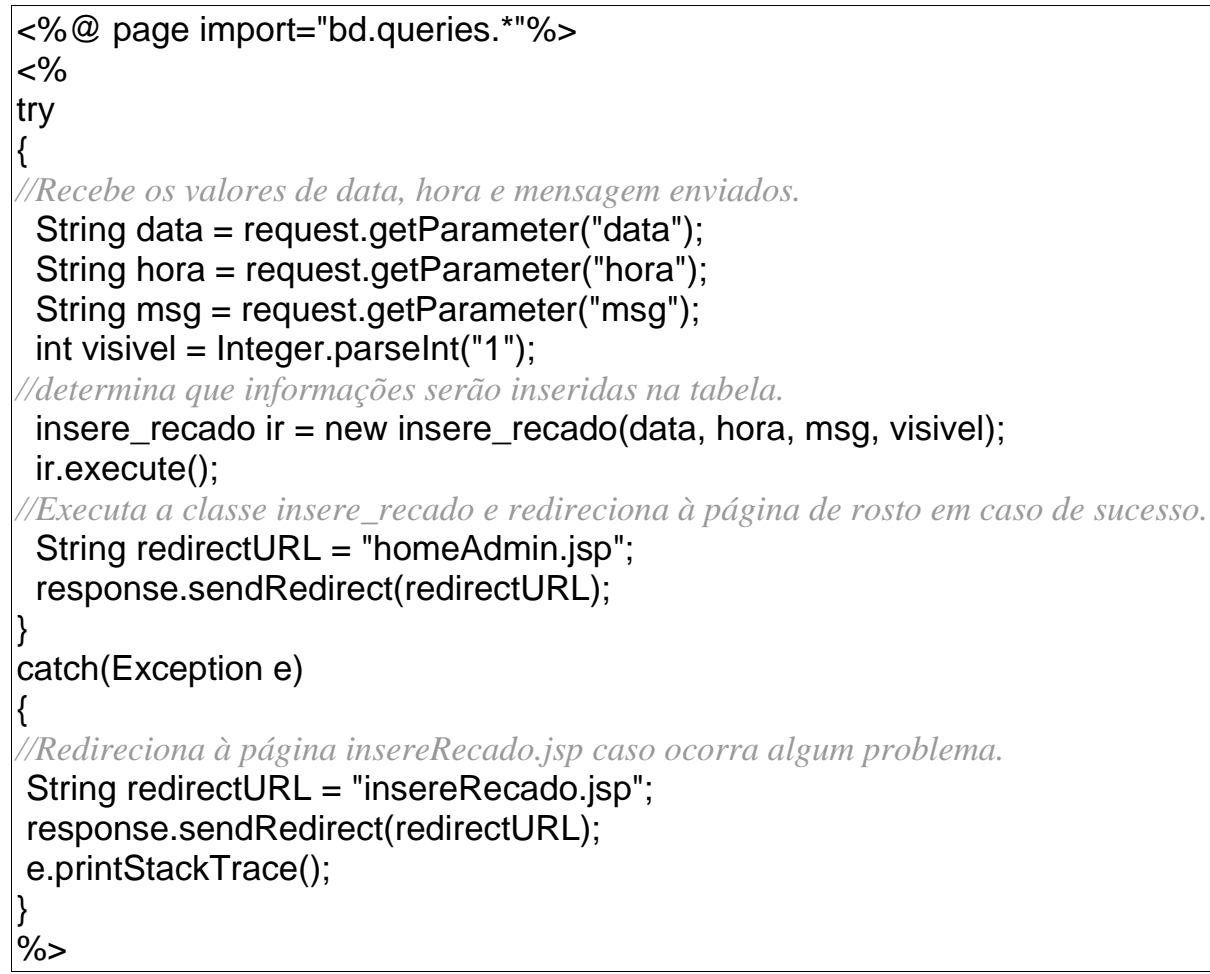

Quadro 17: Código-fonte da página insereRecadoAction.jsp.

Esta página recebe e organiza os dados, e chama a classe "insere_recado.class", responsável pela inserção das informações na tabela RECADO; a classe é reproduzida no Quadro 18.

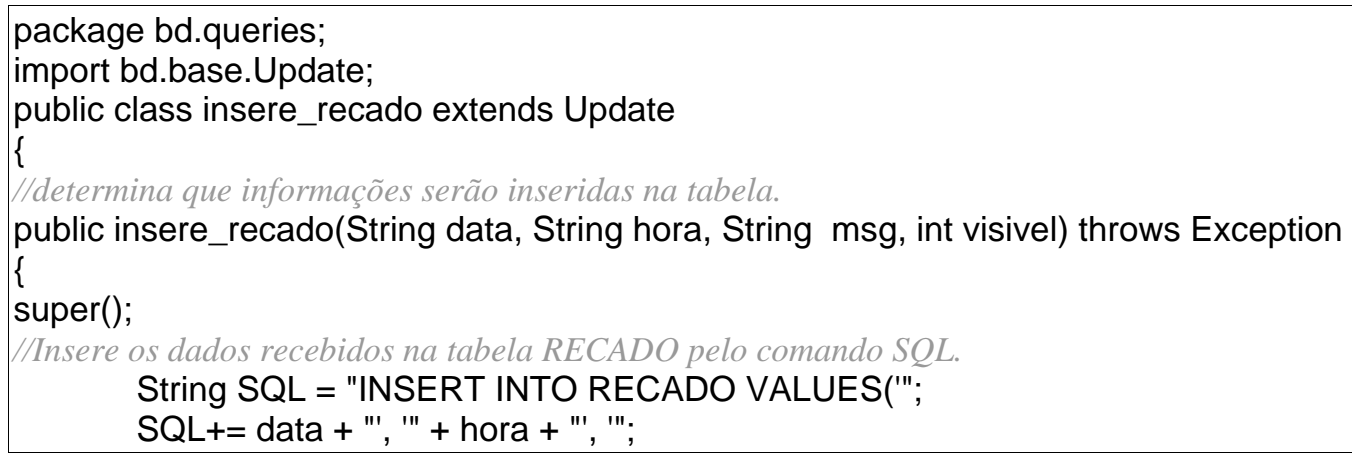


SQL+= msg + "', " + visivel + ");";

this.setSQL(SQL);

\}

Quadro 18: Código-fonte da classe "InsereRecado.class".

\subsubsection{Página Verifica Relatórios}

A página Verifica Relatórios permite a um administrador verificar os relatórios enviados em uma tabela ordenada de maneira cronológica. Para tanto, no acesso a esta página, um scriptlet seleciona todos os relatórios existentes, e imprime na página uma lista com o número do relatório (e link para seu conteúdo), login do aluno, nome do aluno, data e hora de envio e turma que o aluno freqüenta, mostrado na Figura 14. $\mathrm{O}$ administrador deve então escolher o relatório a visualizar e clicar no link correspondente.

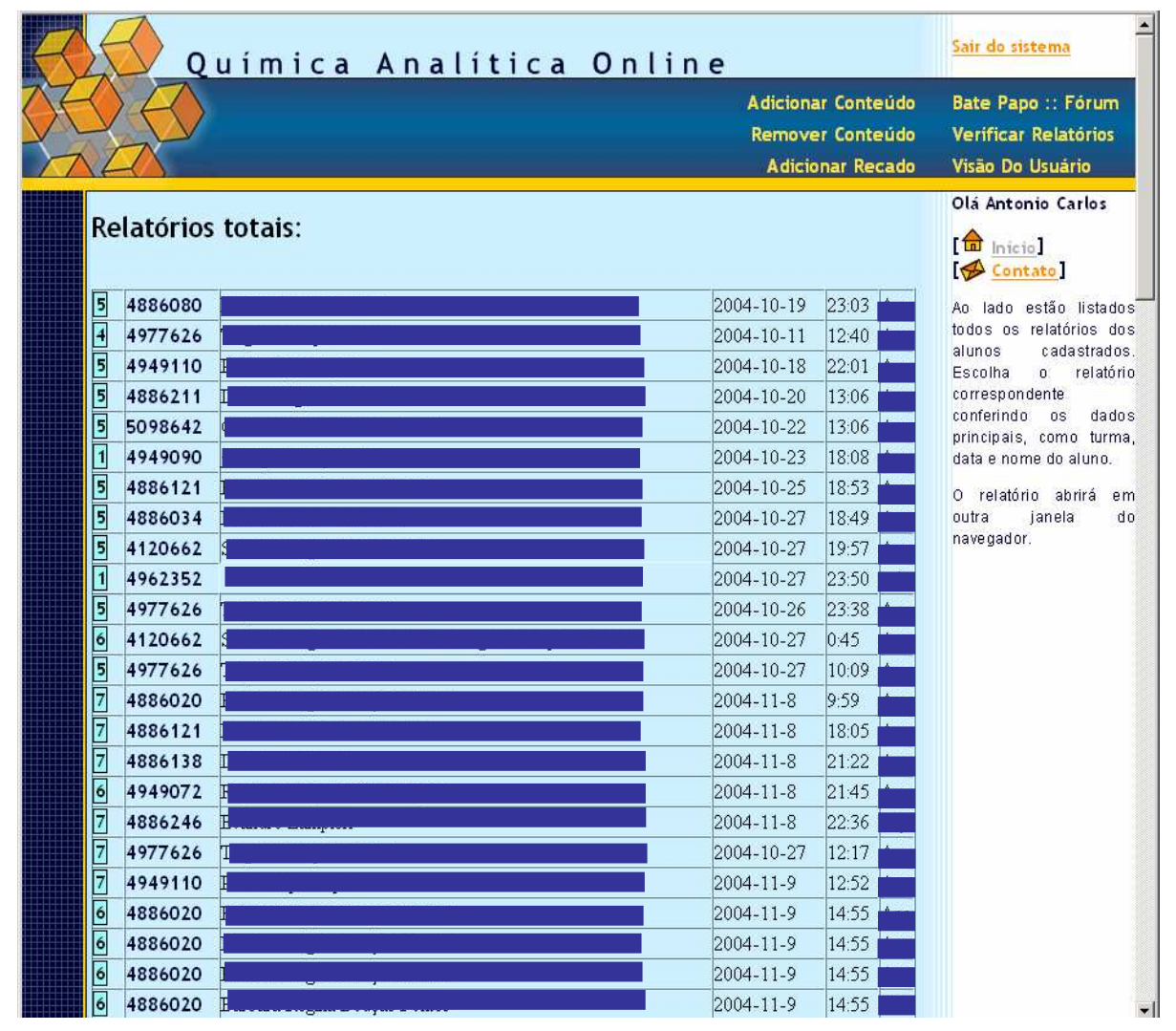

Figura 14: Representação da página verificaRelatorio.jsp. 
O scriptlet do Quadro 19 utiliza as classes "seleciona_relatorio" e "HtmlTableRelatorio" respectivamente para a seleção e formatação das informações. As classes citadas são reproduzidas nos Quadros 20 e 21.

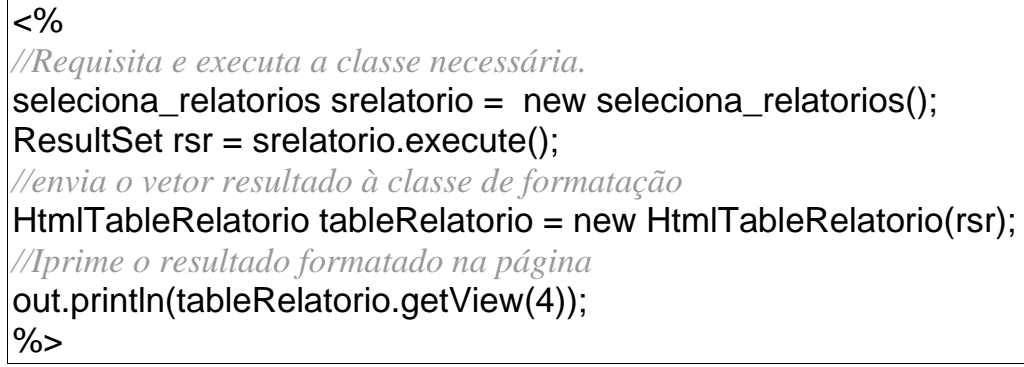

Quadro 19: Scriptlet usado na página verificaRelatorio.jsp.

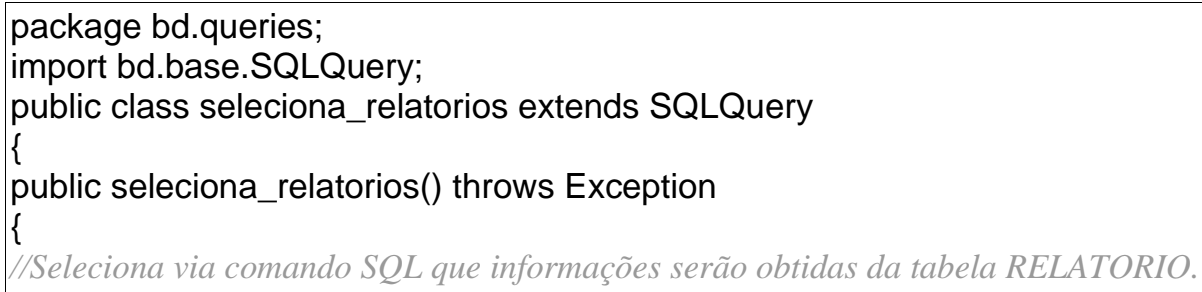

Quadro 20: Classe "seleciona_relatorios". Seleciona da tabela RELATORIO o número da prática, número do aluno, nome, data, hora e turma, de forma a gerar o índice visto na página verificaRelatorio.jsp 


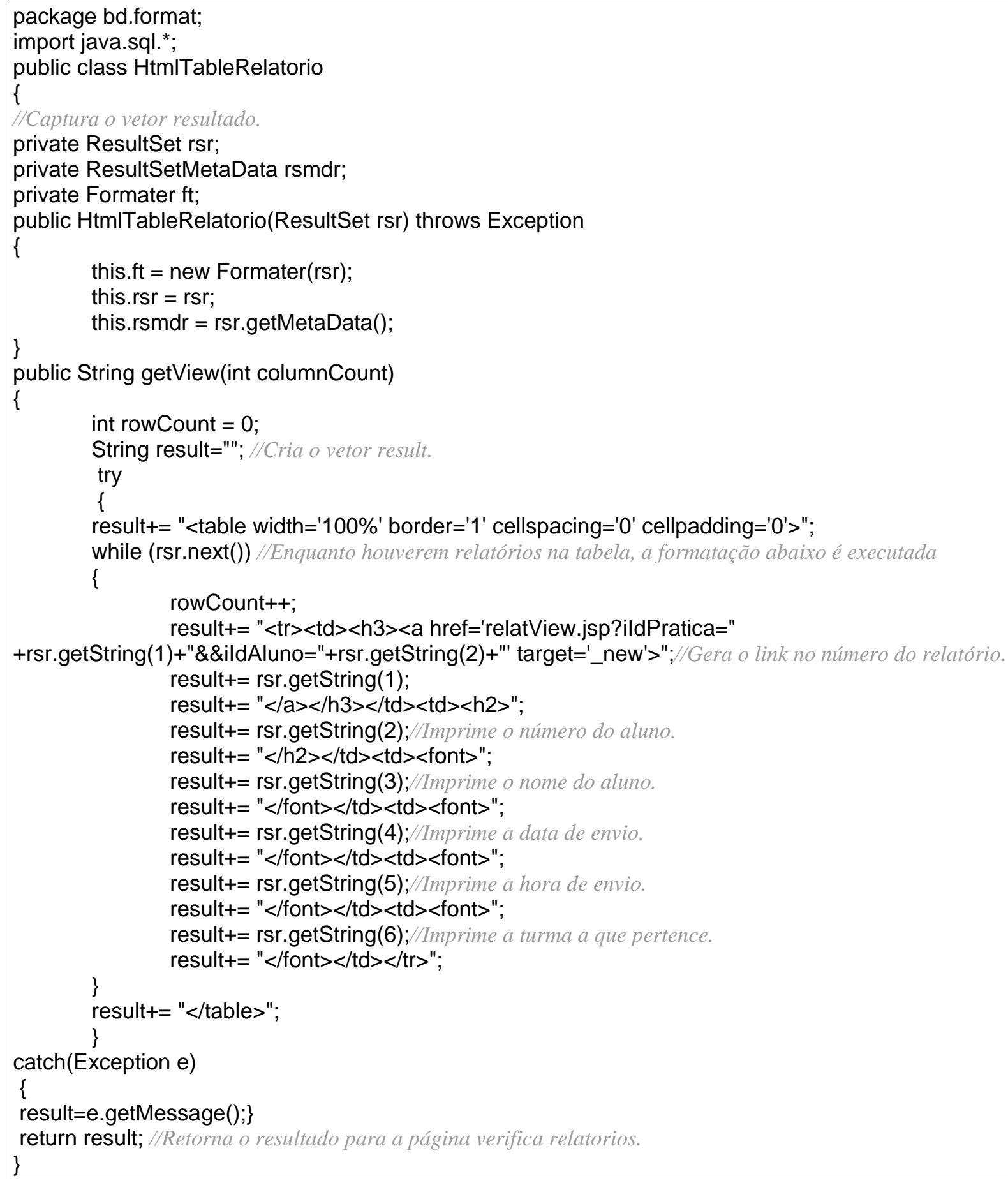

Quadro 21: Código-fonte da classe "HtmlTableRelatorio".

Após a formatação do conteúdo obtido da base de dados, o resultado é enviado ao scriptlet original que imprime o código HTML resultante. 


\subsection{Módulo Aluno}

No caso de acesso à aplicação por um usuário classificado como aluno, suas possibilidades são: acessar o bate-papo, o fórum, uma das 3 áreas de leitura, o glossário relacionado ou enviar relatório. Visto que a exibição de recados na página de rosto é a mesma em ambos os módulos, e já foi explicada anteriormente, passamos a detalhar as outras páginas do módulo aluno ainda não explicadas.

\subsubsection{Páginas de leitura}

As páginas de leitura são as páginas que exibem o conteúdo teórico do curso, em nosso caso são três páginas distintas, no qual apenas a área de concentração é modificada. A página de leitura do conteúdo de Algarismos Significativos é mostrada na Figura 15.

\begin{tabular}{|c|c|c|}
\hline $\mathrm{Qu}$ im $\mathrm{i}$ & 1 & Sair do sistema \\
\hline & $\begin{array}{l}\text { Algarismos Significativos } \\
\text { Análise Gravimétrica } \\
\text { Trabalho Final De Curso }\end{array}$ & $\begin{array}{l}\text { Bate Papo : Fórum } \\
\text { Enviar Relatório } \\
\text { Glossário }\end{array}$ \\
\hline 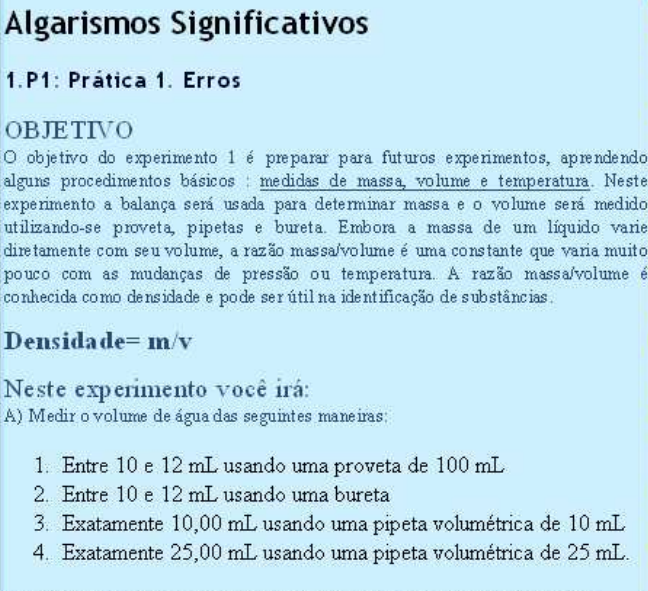 & $\begin{array}{l}\text { 1.0:Sinais Analuticos e } \\
\text { yerdades estatisticas. } \\
\text { 1.1:Algarismos Significativos } \\
\text { e Figuras Significativas em } \\
\text { Quimica Analútica. } \\
\text { 1.2:Definiçäes e terminologia } \\
\text { na Análise Estatistica de } \\
\text { resultados anaúticos } \\
\text { 1.3:Média e Mediana. } \\
\text { 1.4:Tipos de erros em } \\
\text { resultados experimentais. } \\
\text { 1.4.1:Estimativa do Desvio } \\
\text { Padräo e de Confiabilidade } \\
\text { Analutica } \\
\text { 1.4.3:Exatidäo, Erro Médio } \\
\text { Absoluto e Erro médio } \\
\text { Relativo de resultados. } \\
\text { 1.5:Teste novo }\end{array}$ & 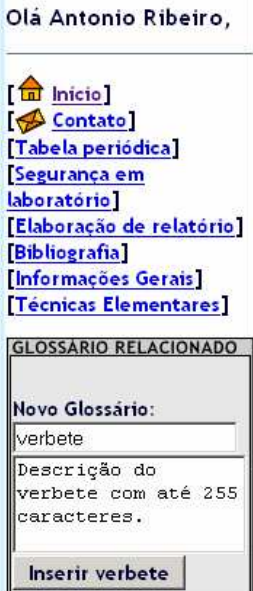 \\
\hline
\end{tabular}

Figura 15: Exemplo de uma das páginas de leitura do sítio. 
As páginas de leitura possuem um scriptlet de seleção do conteúdo adicionado pela página insereConteudo.jsp. O scriptlet responsável pela obtenção e formatação do conteúdo é mostrado no Quadro 22.

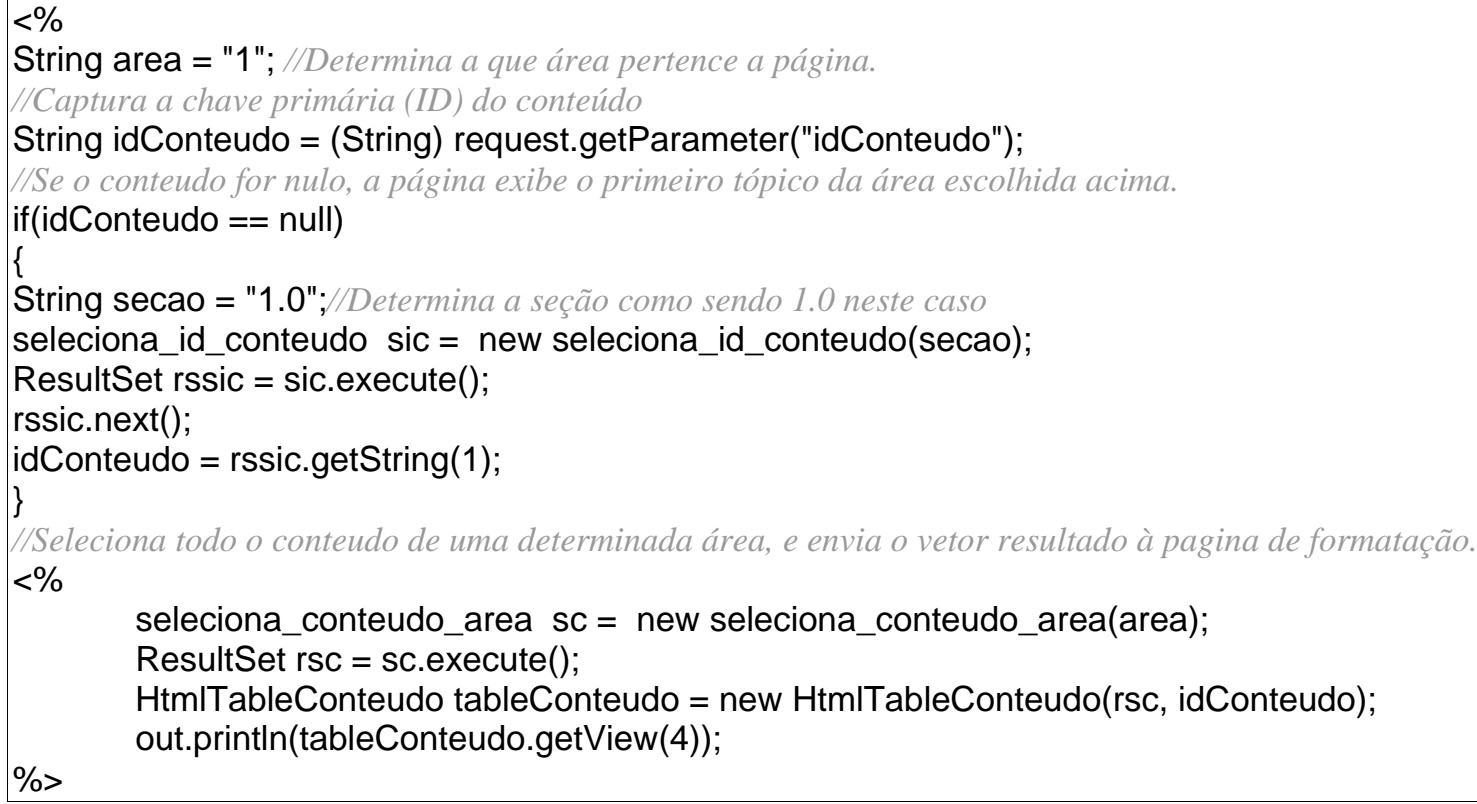

Quadro 22: Scriptlet usado nas páginas de leitura.

A página de leitura determina primeiro se existe um conteúdo a exibir. Caso a variável idConteudo esteja vazia, a página exibe o primeiro tópico pertencente a área em questão. Caso o idConteudo exista, a página seleciona toda a informação da área a que o conteúdo pertença e envia o resultado à classe "HtmlTableConteudo.class" que formata o texto e gera os links para os outros tópicos desta área. O código fonte para a classe "seleciona_conteudo_area" e "HtmlTableConteudo" são reproduzidos e comentados nos Quadros 23 e 24. 


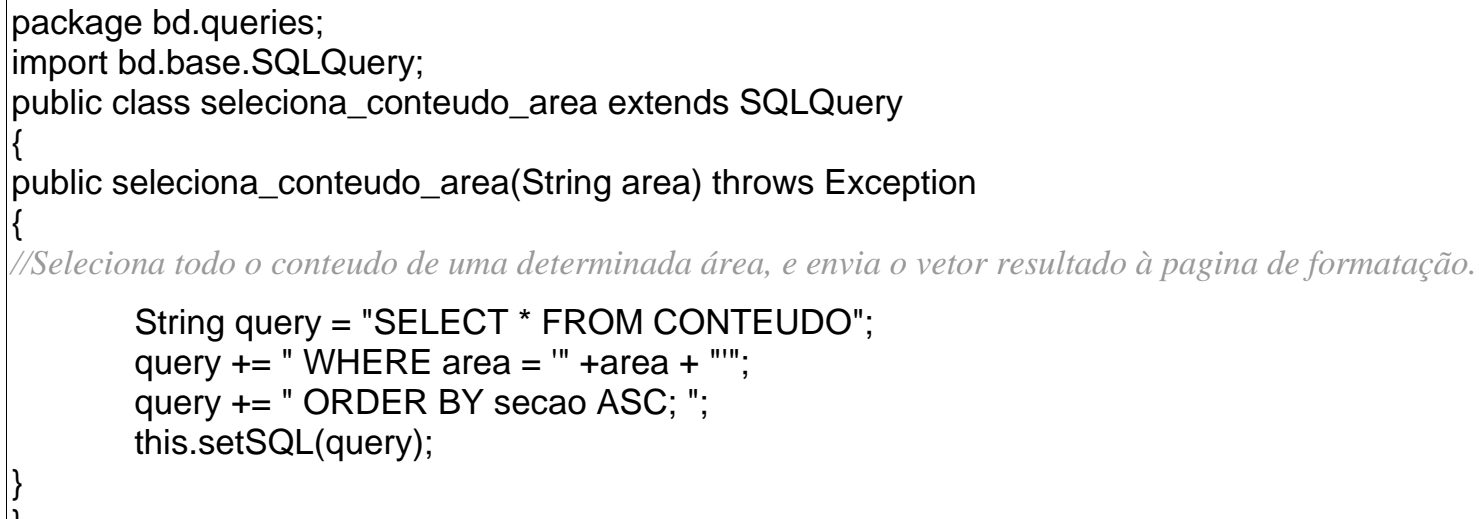

Quadro 23: Código-fonte para a classe "seleciona_conteudo_area”. 


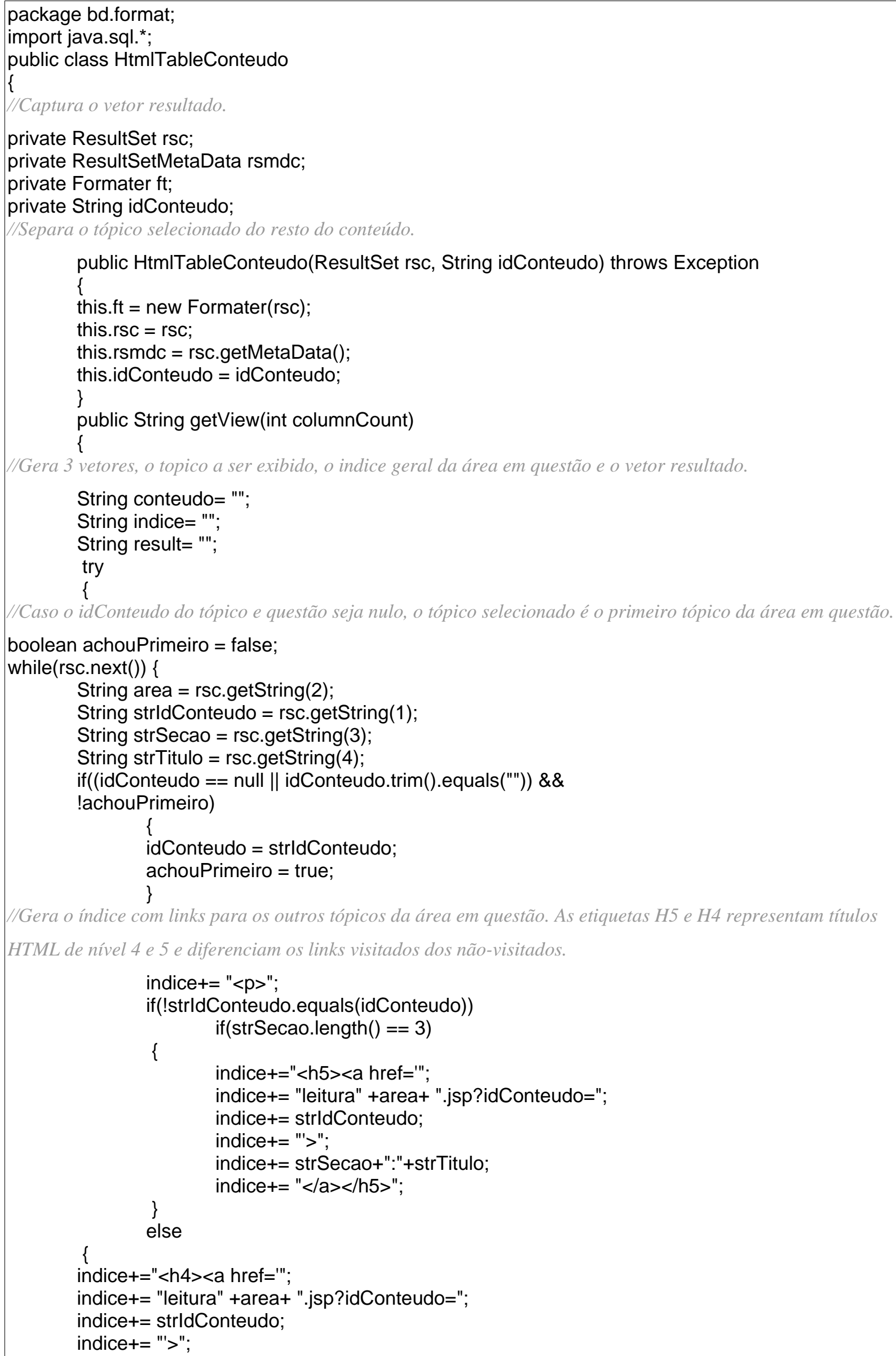




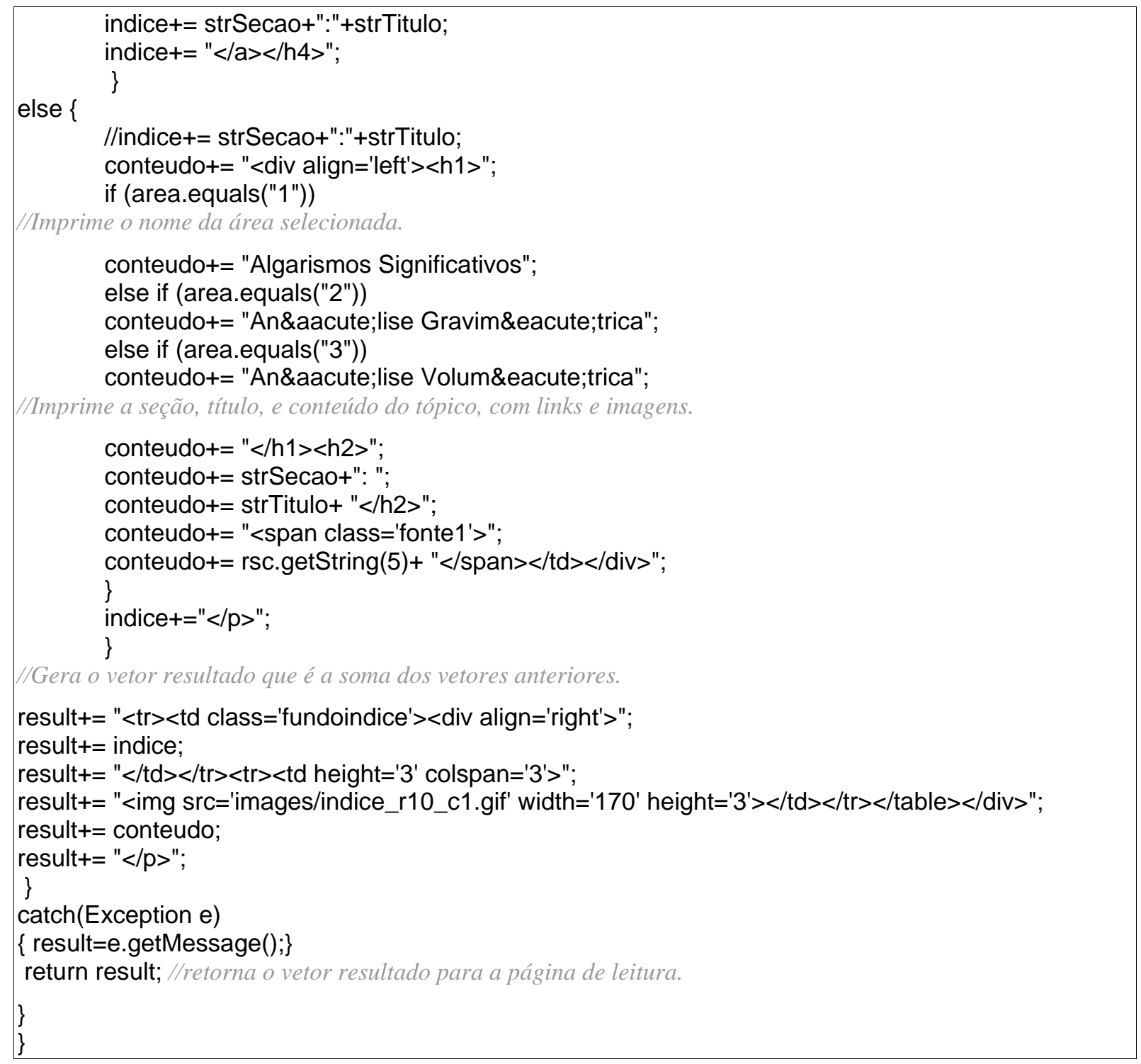

Quadro 24: Código-fonte de classe "HtmlTableConteudo".

\subsubsection{Página Envio de Relatório}

A página Envio de Relatório possui em sua zona principal um formulário para edição do relatório diretamente no navegador como mostra a Figura 16. 


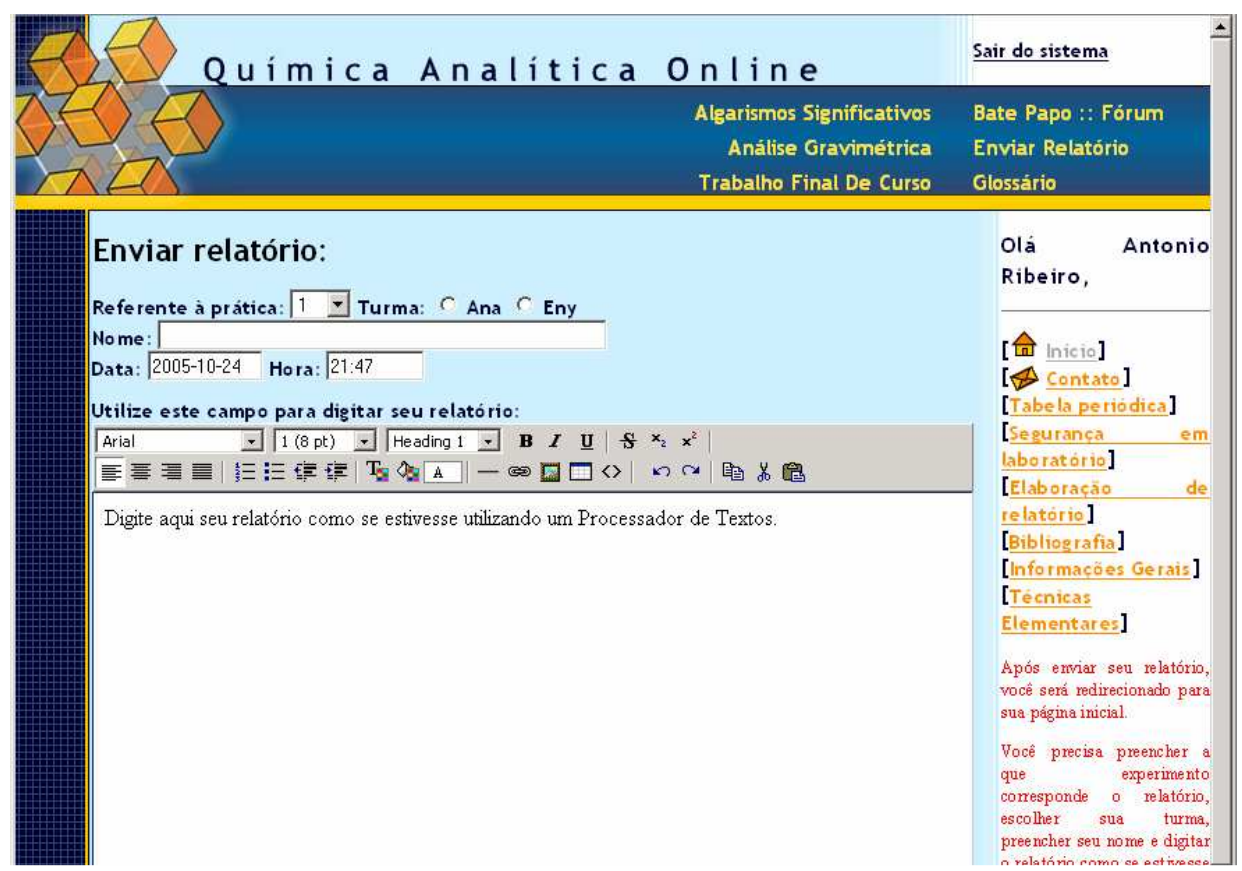

Figura 16: Representação da página Envio de Relatório.

O aluno deve definir a que prática se refere o relatório a ser enviado, a que turma o aluno pertence e seu nome completo. Data e hora são preenchidos automaticamente pelo sistema. A digitação do relatório é feita utilizando uma ferramenta gratuita escrita em Javascript chamada HTMLArea ${ }^{74}$ que permite ao aluno editar o relatório como se estivesse utilizando um software de edição de texto (como o Microsoft Word $^{\mathrm{TM}}$ por exemplo). O fluxo da informação para esta página é o mesmo da página de inserção de conteúdo, apenas os dados que serão armazenados não são os mesmos, assim não consideramos necessária uma explicação mais detalhada do código desta página.

\subsubsection{Página Glossário}

De forma semelhante à página de Rosto, a página Glossário faz a seleção de todas as informações existentes na tabela GLOSSARIO da base e imprime os verbetes em ordem alfabética no navegador como na Figura 17. 


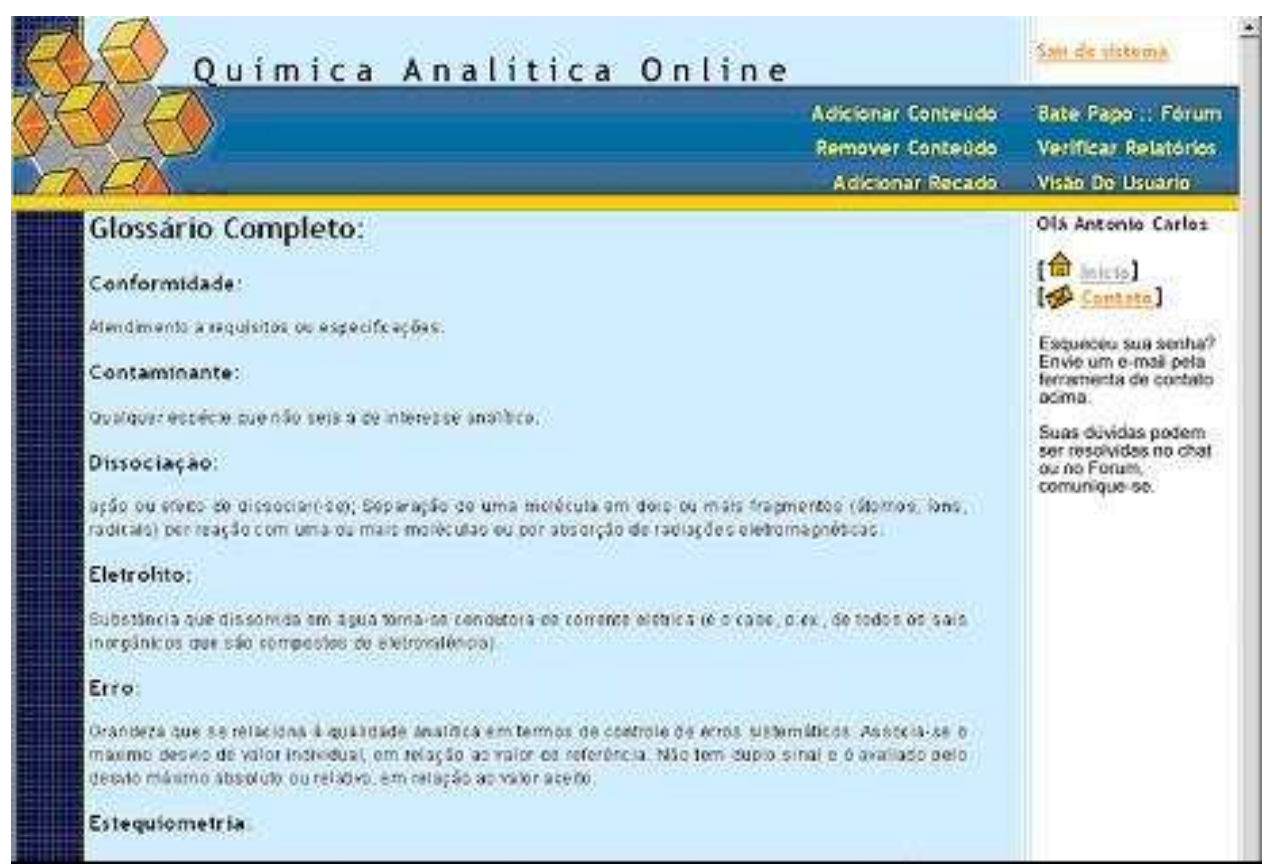

Figura 17: Representação da página Glossário.

O código fonte responsável pela seleção da informação e impressão do resultado é inserido na zona principal da página pelo scriptlet reproduzido no Quadro 25.

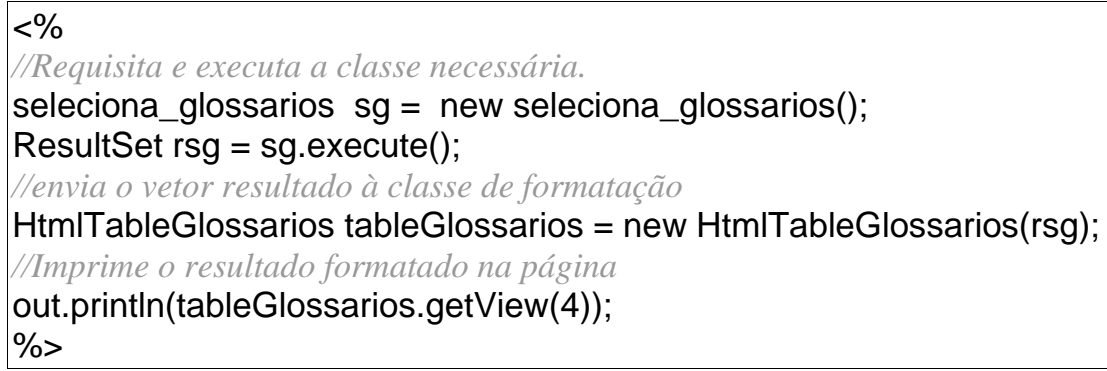

Quadro 25: Scriptlet usado na página de glossário.

Este scriptlet utiliza as classes "seleciona_glossarios" e "HtmlTableGlossarios" na seleção e formatação dos dados. O código fonte das duas classes é transcrito nos Quadros 26 e 27. 
package bd.queries;

import bd.base.SQLQuery;

public class seleciona_glossarios extends SQLQuery

\{

public seleciona_glossarios() throws Exception

\{//Seleciona todo o conteudo da tabela GLOSSARIO, e ordena por "id" de maneira ascendente.

String query = "SELECT * FROM GLOSSARIO ORDER BY id ASC";

\}\} this.setSQL(query);

Quadro 26: Código-fonte da classe "seleciona_glossario".

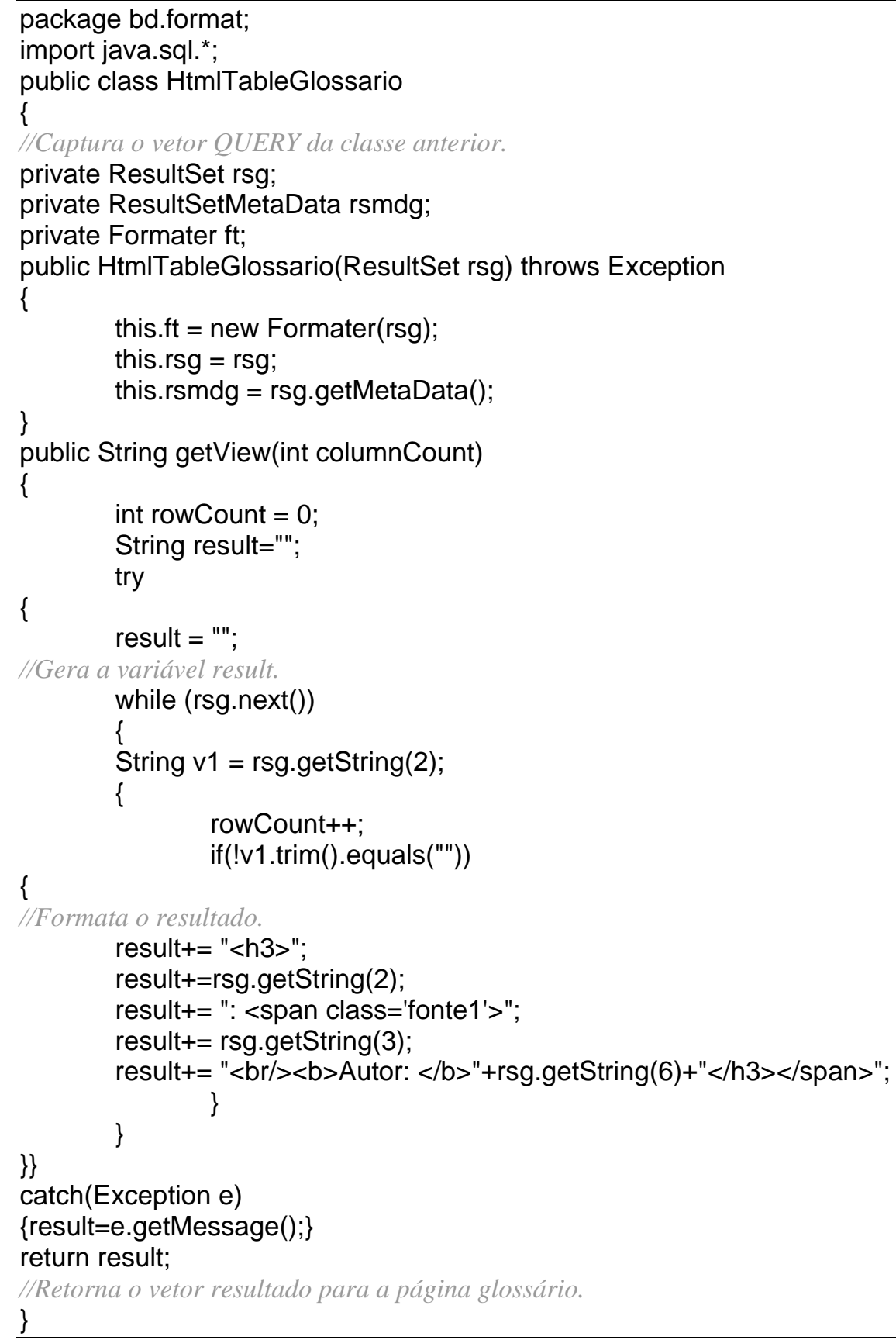


\}

Quadro 27: Código-fonte da classe "HtmlTableGlossario".

\subsubsection{Página Contato}

Uma página Contato com o administrador do sítio ainda foi disponibilizada permitindo aos estudantes contatarem o responsável pelo sítio a fim de resolver qualquer dúvida. A página Contato utiliza apenas funcionalidades da linguagem HTML. Um formulário simples (transcrito no Quadro 28) captura o nome do aluno, endereço de e-mail, titulo do contato e o texto escrito, e envia um e-mail para “contato@qaonline.locaweb.com.br" a partir do aplicativo "formmail.pl". Este código simples disponibilizado pelo provedor de hospedagem envia um e-mail ao endereço escolhido com os dados capturados no formulário.

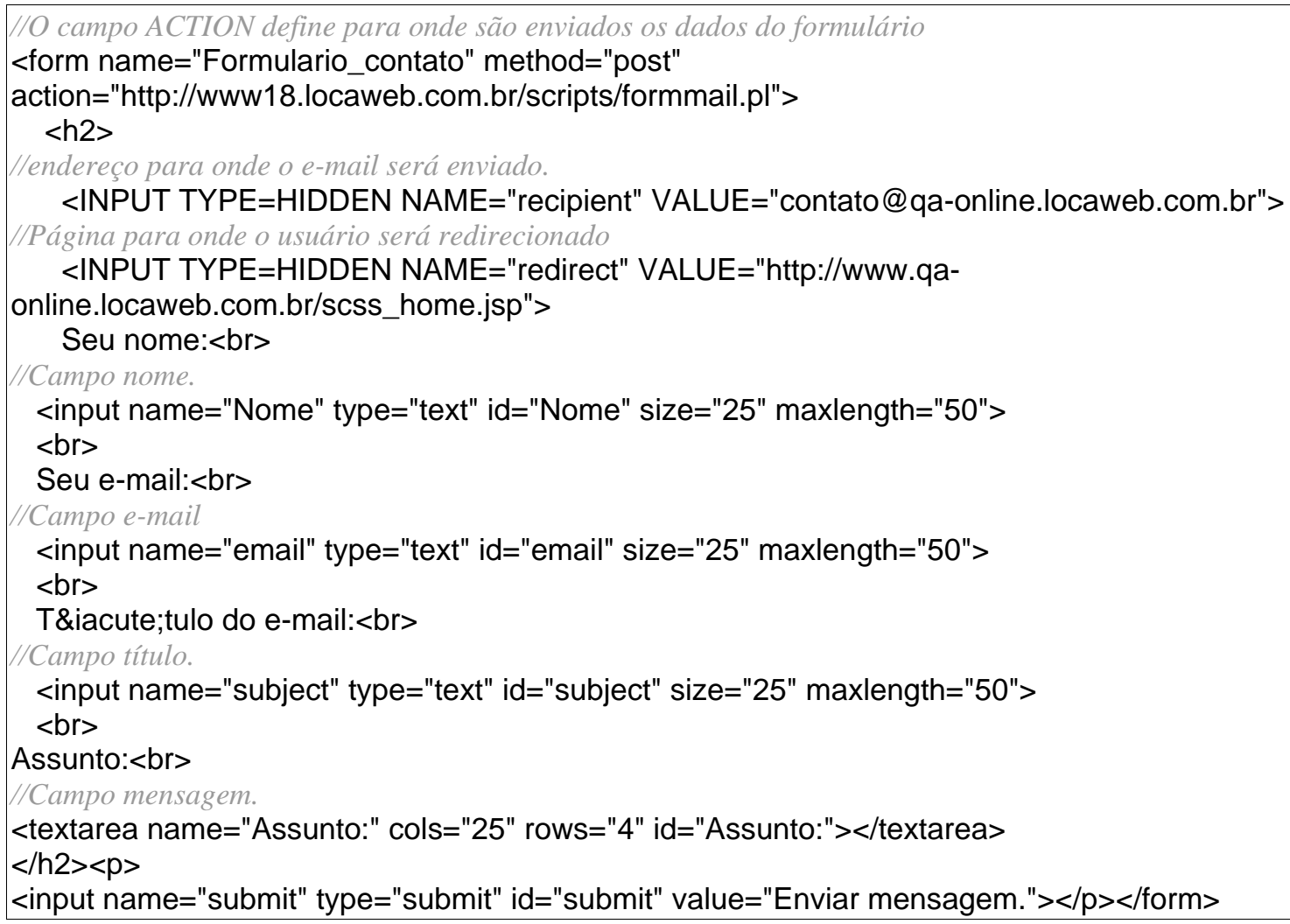

Quadro 28: Código-fonte da página de contato. 
Após o envio correto do e-mail ao destinatário, o usuário é redirecionado à página de rosto com uma mensagem de sucesso completando a operação.

\subsection{Ferramentas}

Algumas ferramentas gratuitas disponibilizadas tanto pelo provedor de hospedagem quanto encontradas na Web foram utilizadas com o intuito de melhorar algumas funcionalidades do sítio.

\subsubsection{Ferramenta HTMLArea}

HTMLArea é um editor de texto online e gratuito que funciona diretamente dentro do navegador. Ele permite a edição de texto em formato HTML diretamente por uma caixa de texto customizada. Possui funções de negrito, itálico, sobrescrito, subscrito entre outras necessárias para a edição de textos em química. É codificado em Javascript, o que faz com que sua implementação em uma página Web seja simples. Maiores detalhes e versões podem ser encontrados no endereço http://www.dynarch.com/projects/htmlarea/ ${ }^{74}$.

\subsubsection{Ferramenta de preenchimento de data e hora}

O preenchimento automático de data e hora é utilizado no sítio em duas situações distintas: no campo data e hora da página de inserção de recados e na ferramenta de monitoramento da navegação presente na página de Rosto, páginas de leitura, Glossário e Envio de Relatórios. O código fonte deste Javascript é reproduzido e comentado no Quadro 29. 


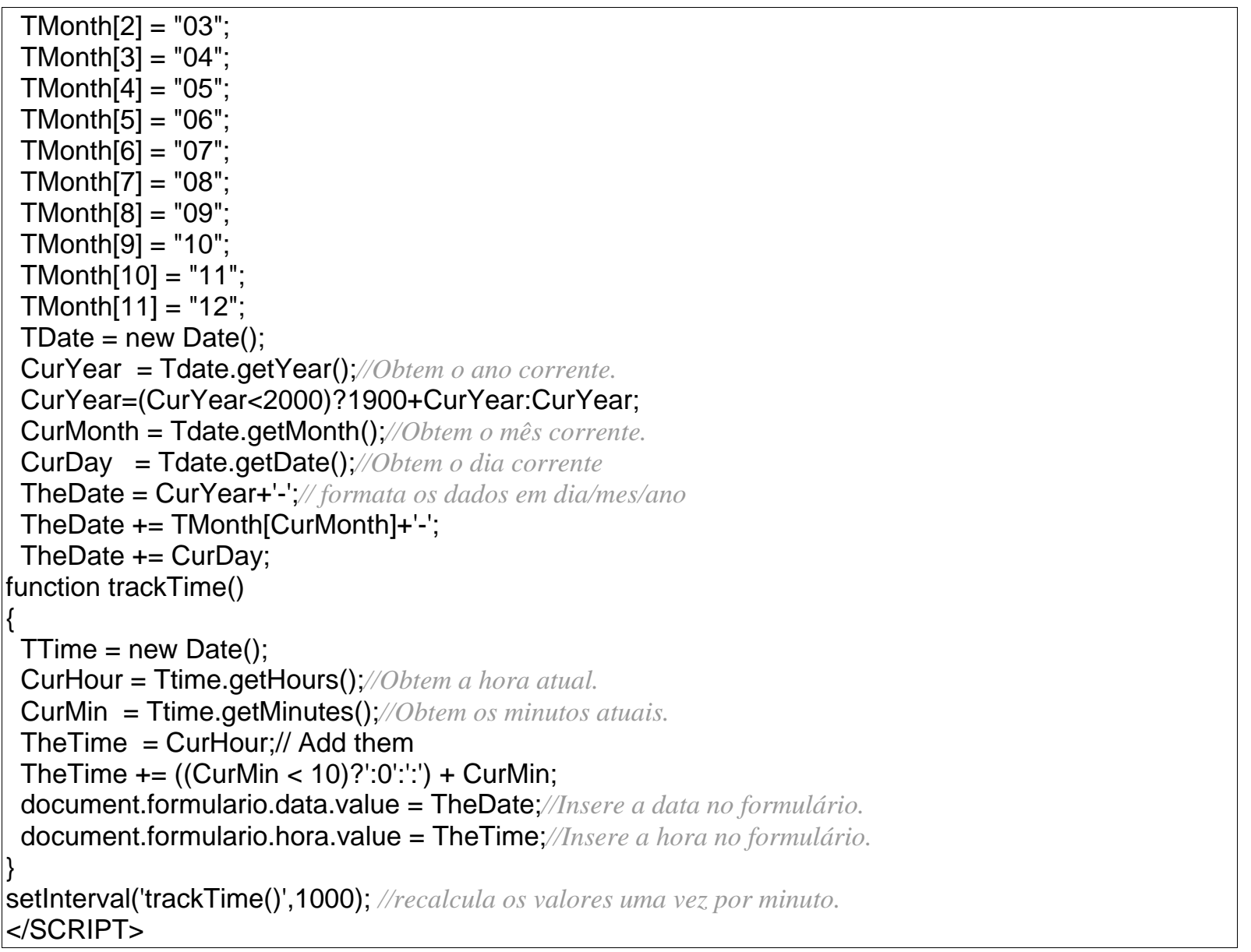

Quadro 29: Código-fonte da ferramenta de inserção de data e hora.

\subsubsection{Ferramenta de verificação de formulários}

A ferramenta de verificação de formulários ${ }^{75}$ foi utilizada com a intenção de evitar que alguma informação importante fosse desprezada. Esta ferramenta, escrita em javascript, verifica dados de um formulário antes que sejam enviados à camada Modelo da aplicação. O código-fonte e sua sintaxe de utilização podem ser encontrados em http://www.swcat.com ${ }^{75}$.

\subsubsection{Ferramenta de mapeamento da navegação}

A ferramenta de mapeamento da navegação foi criada com o objetivo de armazenar um histórico da navegação dos estudantes a fim de entendermos como os alunos navegam. Esta ferramenta armazena, em ordem cronológica, informações do usuário, data e hora de acesso e a página acessada. O código-fonte do Quadro 30 é inserido diretamente nas páginas 
que desejamos mapear. A classe responsável pelo armazenamento dos dados na base é transcrita no Quadro 31.

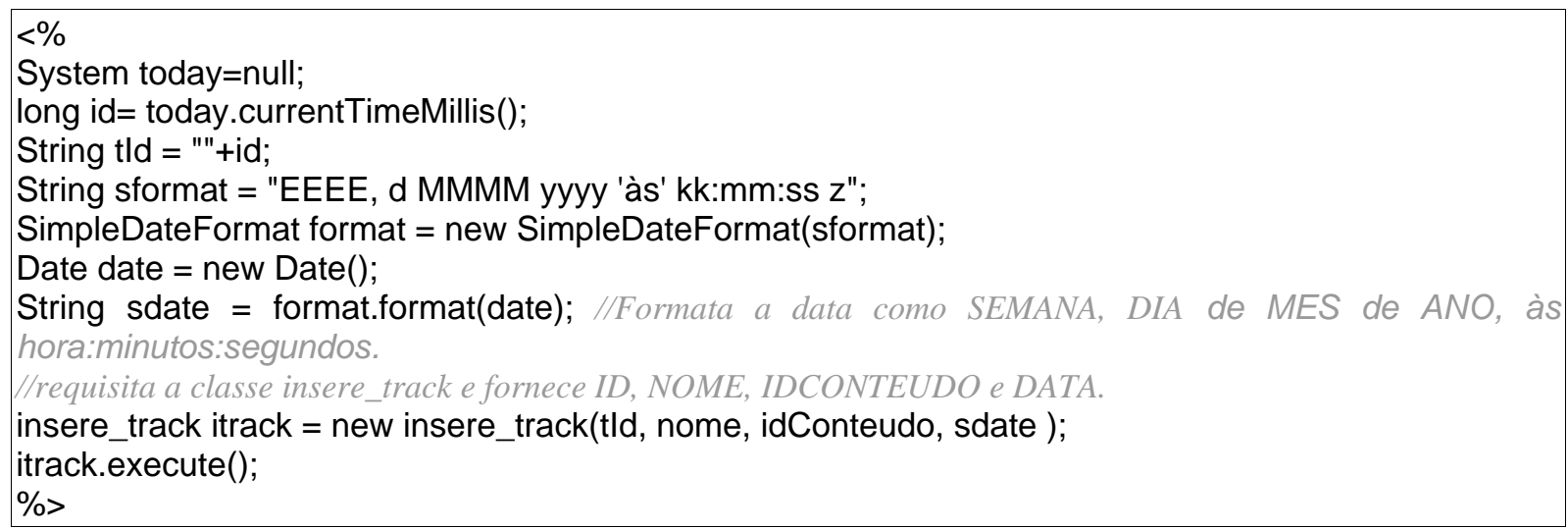

Quadro 30: Código-fonte da ferramenta de mapeamento da navegação.

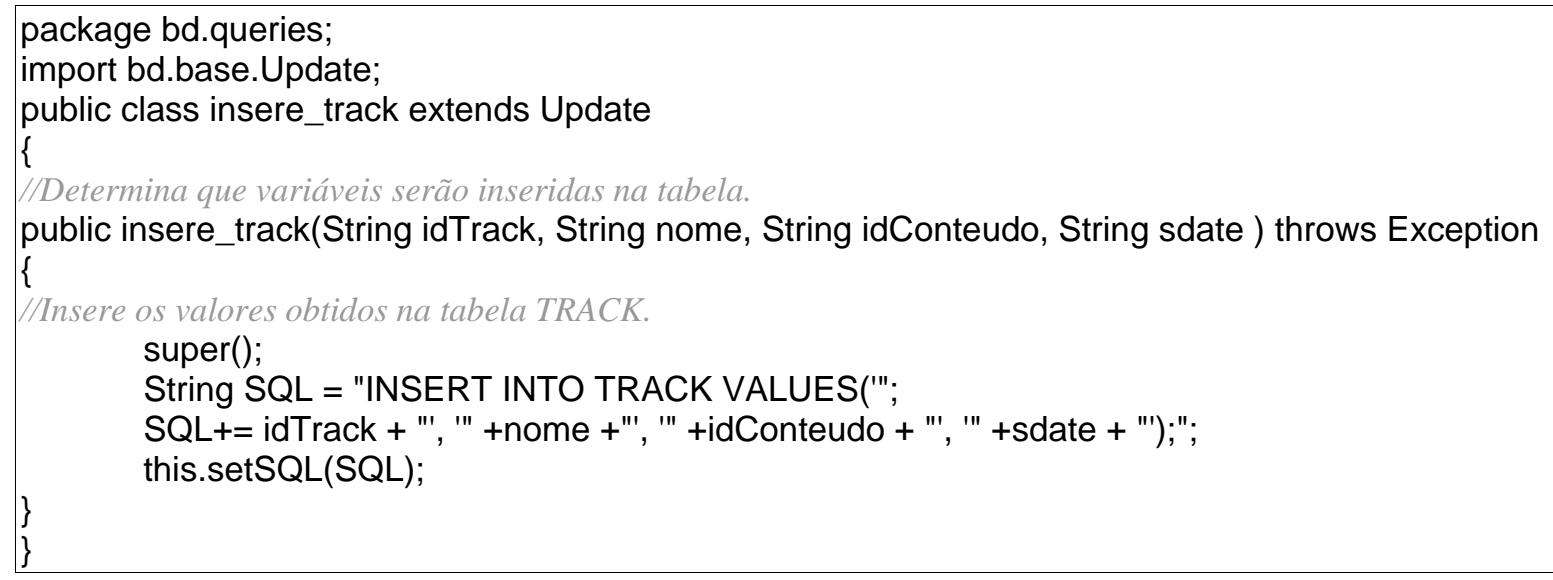

Quadro 31: Código-fonte da classe "insere_track".

A classe "insere_track.class" preenche a tabela TRACK com a chave primária, o nome do usuário, a identificação da página, a data e a hora de visita, compondo então uma tabela cronológica de acessos às páginas do sistema. 


\section{RESULTADOS E DISCUSSÃO}

Embora seja considerável a quantidade de materiais educacionais, destinados ao ensino de química, disponíveis na Internet, vários pesquisadores apontam para a escassez de pesquisas que investigam a sua efetividade no processo de ensino e aprendizagem desta disciplina e a sua aceitação e forma de utilização pelos estudantes ${ }^{28,29,30}$. Neste trabalho nos dedicamos a investigar estes dois últimos aspectos, no que diz respeito ao sítio de Internet por nós construído e anteriormente descrito no capítulo Construção do Sítio de Internet desta dissertação. Para tanto, buscamos subsídios em trabalhos publicados nas revistas Journal of Chemical Education e The Chemical Educator, no intervalo de Janeiro de 1995 a Julho de 2005, que mencionam a realização de pesquisas desta natureza. Verificamos que, na grande maioria delas, a aceitação dos alunos aos recursos disponibilizados, via Web foi avaliada através da aplicação de questionários aos estudantes ${ }^{26,28-30,35,40,76-79}$. Observações em sala de aula $^{32}$, solicitação de comentários escritos ${ }^{3,29}$ e entrevistas ${ }^{26,29}$ com os envolvidos no processo de aplicação dos recursos foram também estratégias adotadas por alguns pesquisadores. A forma de utilização pelos alunos, dos recursos disponibilizados via Web foi analisada através da aplicação de questionários aos alunos ${ }^{26,32}$ e do monitoramento do acesso feito por eles a estes recursos $3,28,40,77$.

Neste trabalho adotamos procedimentos semelhantes aos reportados na literatura e analisamos as percepções e a aceitação dos alunos quanto ao sítio através da aplicação de questionários. A forma de utilização foi analisada através de dados coletados a partir do monitoramento da navegação dos alunos em algumas páginas do sítio. A seguir apresentamos 
a caracterização dos sujeitos da pesquisa e os resultados alcançados a partir da análise dos dados obtidos.

\subsection{Caracterização dos sujeitos de pesquisa}

Os professores da Turma 1 e Turma 2, considerados como sujeitos da pesquisa, foram contratados no Instituto em 1989 e 1992, respectivamente e, desde então, ministram a disciplina Laboratório de Química Analítica Quantitativa. O estagiário da Turma 2 é doutorando pelo programa de Química Analítica do Instituto desde o ano 2001.

A caracterização dos alunos que participaram como sujeitos da pesquisa foi feita a partir de dados extraídos das respostas apresentadas a 23 questões existentes em um questionário por eles preenchido no momento de cadastro no sítio. O referido questionário encontra-se no Anexo B desta dissertação. No semestre de aplicação do sítio, a disciplina contava com 56 alunos matriculados, sendo que 32 deles $(57,1 \%)$ se cadastraram no sítio. Dentre os sujeitos, $14(43,8 \%)$ são do sexo feminino e $18(56,2 \%)$ do sexo masculino, com idade média de 21,3 anos; 19 são alunos da Turma 1 e 13 alunos da Turma 2.

A Tabela 1 sintetiza as principais informações obtidas através das respostas dos alunos ao questionário. A partir da análise destas informações verificamos que o sítio foi utilizado principalmente por ingressantes no Curso de Bacharelado em Química no ano de 2003, que compreendem 84,4\% do total de alunos cadastrados no sítio. Com relação à formação anterior, verificamos que 40,6\% dos alunos realizaram o ensino médio na rede privada de ensino e 40,6\% na rede pública. Em contrapartida, 18,8\% dos alunos realizaram o ensino médio em escolas tanto da rede privada quanto da rede pública. 
Tabela 1: Frequiência e porcentagem de respostas para cada um dos itens do questionário de caracterização do aluno.

\begin{tabular}{|c|c|c|c|}
\hline QUESTÃO & OPÇÕES & FREQÜÊNCIA & PORCENTAGEM (\%) \\
\hline \multirow{2}{*}{ Gênero } & Masculino & 18 & $\overline{56,2}$ \\
\hline & Feminino & 14 & 43,8 \\
\hline \multirow{3}{*}{$\begin{array}{l}\text { Ano de ingresso na } \\
\text { Universidade }\end{array}$} & Anterior a 2003 & 3 & 9,4 \\
\hline & 2003 & 27 & 84,4 \\
\hline & Posterior a 2003 & 2 & 6,2 \\
\hline \multirow{3}{*}{$\begin{array}{l}\text { Onde você realizou o ensino } \\
\text { médio? }\end{array}$} & Rede privada & 13 & 40,6 \\
\hline & Rede pública & 13 & 40,6 \\
\hline & Rede privada e rede pública & 6 & 18,8 \\
\hline \multirow{2}{*}{$\begin{array}{l}\text { Tem acesso a algum } \\
\text { microcomputador? }\end{array}$} & Não & 1 & 3,1 \\
\hline & Sim & 31 & 96,9 \\
\hline \multirow{2}{*}{ Se sim, qual tipo? } & PC & 31 & 96,9 \\
\hline & Macintosh & 1 & 3,1 \\
\hline \multirow{5}{*}{$\begin{array}{l}\text { Onde você costuma utilizar } \\
\text { mais freqüentemente o } \\
\text { computador? }\end{array}$} & Casa & 10 & 31,3 \\
\hline & Universidade & 21 & 65,6 \\
\hline & Trabalho & 1 & 3,1 \\
\hline & Outro & 0 & 0,0 \\
\hline & Windows & 31 & 96,9 \\
\hline \multicolumn{2}{|c|}{ Que sistema operacional está MacOS } & 1 & 3,1 \\
\hline \multirow[t]{2}{*}{ instalado? } & Linux & 0 & 0,0 \\
\hline & Outro & 0 & 0,0 \\
\hline \multirow{2}{*}{ Possui acesso a Internet? * } & Sim & 29 & 93,5 \\
\hline & Não & 2 & 6,5 \\
\hline \multirow{5}{*}{ 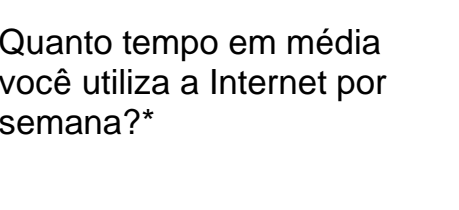 } & Menos de 1 hora & 13 & 41,9 \\
\hline & $1-5$ horas & 13 & 41,9 \\
\hline & $5-10$ horas & 3 & 9,7 \\
\hline & Mals de 10 horas & 2 & 6,5 \\
\hline & Internet Explorer & 28 & 90,3 \\
\hline \multirow{4}{*}{$\begin{array}{l}\text { Que programa navegador } \\
\text { você utiliza? * }\end{array}$} & Netscape Navigator & 0 & 0,0 \\
\hline & Opera & 2 & 6,5 \\
\hline & Outro & 1 & 3,2 \\
\hline & $\begin{array}{l}\text { resoluçao de exercicios e } \\
\text { trabalhos }\end{array}$ & 26 & 83,8 \\
\hline \multirow{4}{*}{$\begin{array}{l}\text { Com que objetivos você } \\
\text { utiliza a Internet? * }\end{array}$} & E-mail & 2 & 6,5 \\
\hline & Entretenimento & 3 & 9,7 \\
\hline & Comunidades Virtuais & 0 & 0 \\
\hline & $\begin{array}{l}\text { Não me sinto confortável ao } \\
\text { utilizar }\end{array}$ & 1 & 3,2 \\
\hline \multirow{3}{*}{$\begin{array}{l}\text { Qual das afirmativas poderia } \\
\text { traduzir melhor sua relação } \\
\text { com a Internet? }{ }^{*}\end{array}$} & $\begin{array}{l}\text { Consigo apenas os resultados } \\
\text { que necessito }\end{array}$ & 11 & 35,5 \\
\hline & $\begin{array}{l}\text { Quase sempre consigo mais } \\
\text { do que esperava }\end{array}$ & 7 & 22,6 \\
\hline & $\begin{array}{l}\text { Sinto-me completamente } \\
\text { confortável ao utilizar }\end{array}$ & 12 & 38,7 \\
\hline
\end{tabular}

* Apenas 31 estudantes responderam a esta questão.

Com relação ao questionamento sobre o acesso dos alunos a microcomputadores, embora um deles tenha mencionado não possuir acesso, podemos afirmar que este é garantido a todos os alunos de graduação do Instituto de Química de São Carlos. Conforme 
mencionamos anteriormente, existe no Instituto uma sala denominada de Sala Pró-Aluno, onde se encontram alocados computadores destinados aos alunos de graduação.

A Tabela 1 mostra que a maior parte dos alunos costuma utilizar computadores, principalmente do tipo PC (sistema operacional Windows), mais freqüentemente na Universidade. O percentual de respostas obtido para a opção Universidade na pergunta "Onde você costuma utilizar mais freqüentemente o computador?" foi de $65,6 \%$. Os demais alunos afirmam utilizá-lo mais freqüentemente em Casa $(31,3 \%)$ ou no Trabalho (3,1\%). Com relação ao acesso à Internet, apenas 6,5\% dos alunos afirmam não possuir este tipo de acesso. $\mathrm{Na}$ realidade todos os alunos possuem acesso à Internet, uma vez que os computadores alocados na Sala Pró-Aluno possuem conexão com a Internet.

Conforme afirmam Paulisse e $\operatorname{Polik}^{40}$, a garantia de acesso a computadores e à Internet para todos os alunos matriculados em disciplinas que disponibilizam materiais educacionais via Web é de extrema importância para o sucesso de tais iniciativas. Os autores fazem tal colocação com base na análise da utilização feita pelos alunos do ChemBoard, um sítio por eles produzido. O ChemBoard é acessível de qualquer computador que possua um navegador instalado permitindo assim que professores, estagiários e alunos participem de discussões a partir de casa, do trabalho, ou de computadores alocados no campus. Desta forma a Web se mostra como um excelente meio para transmissão de informações interessantes para os estudantes. Ao contrário dos e-mails e listas de discussão, que utilizam softwares específicos e armazenam informações em uma única máquina, cursos baseados na Web podem ser utilizados de qualquer computador que possua um navegador, sem armazenar dados do usuário na máquina.

Com relação ao programa navegador utilizado pelos alunos no nosso sítio, 90,3\% dos alunos afirmam utilizar o programa mais popular, o Internet Explorer, para navegação na 
Internet. O uso deste navegador diminuiu a possibilidade de ocorrência de problemas relacionados a plataformas, pois outros programas navegadores poderiam exibir as páginas de forma diferente; com o uso deste software podemos afirmar que o sítio foi inteiramente visualizado como foi projetado.

Com relação ao tempo médio de uso da Internet por semana, 83,8\% dos alunos utilizam o meio no máximo 5 horas. Se extrapolarmos este tempo a uma média mensal, com máximo de 20 horas, podemos afirmar que nossos alunos se encontram acima da média mensal do brasileiro, de 12 horas e 28 minutos, conforme pesquisa publicada pelo Ibope ${ }^{80} \mathrm{em}$ Outubro de 2003.

A análise das respostas apresentadas à questão de múltipla escolha "Com que objetivos você utiliza a Internet?" aponta para a clara intenção da maior parte dos alunos $(83,8 \%)$ no emprego da Internet como ferramenta de auxílio para resolução de exercícios e trabalhos solicitados no curso. Neste contexto, faz-se possível especular que a implementação do sítio como ferramenta de suporte para a disciplina veio ao encontro das necessidades dos alunos nela matriculados.

As outras opções, oferecidas como possíveis respostas à pergunta citada, foram assinaladas por poucos alunos: 6,5\% para a opção E-mail e 9,7\% para a opção Entretenimento. Com relação à opção Comunidades Virtuais, nenhum dos alunos a assinalou. Decidimos incluí-la na lista de opções, uma vez que 2003 foi o ano de publicação do sítio Orkut $^{82}$, e em meados de 2004, já poderia estar sendo acessado pelos alunos.

Com o intuito de conhecer as percepções dos alunos com relação ao uso da Internet, a seguinte pergunta, de múltipla escolha, também fez parte do questionário: "Qual das afirmativas poderia traduzir melhor sua relação com a Internet?’. Foram oferecidas as 
seguintes opções: Não me sinto confortável ao utilizar; Consigo apenas os resultados que necessito; Quase sempre consigo mais do que esperava; Sinto-me completamente confortável ao utilizar. As respostas sugerem que apenas 3,2\% dos alunos não se sentem confortáveis em utilizar a Internet, enquanto que $35,5 \%$ conseguem apenas os resultados que necessitam e os demais $(61,3 \%)$ conseguem mais do que necessitam ou se sentem completamente confortáveis em utilizar a Internet. Este resultado pode ser considerado animador. Conforme constata Weaver $^{28}$, o fato dos alunos se sentirem confortáveis no que diz respeito à utilização da Web é um requisito que deve ser considerado como facilitador na implementação de um curso via Web. Em seu trabalho intitulado "Analysis of student use of a World Wide Web site created as a supplement of general chemistry instruction" a autora busca conhecer as razões que desestimularam os estudantes a utilizar o sítio de Internet por ela elaborado e disponibilizado em disciplina de Química Geral. As razões mencionadas foram: impossibilidade de acesso, falta de tempo, desconhecimento ou pouca familiaridade com a Web, desconhecimento da existência do sítio e dificuldades técnicas. Os alunos (20\%) mencionaram também a existência de sentimento de desconforto com relação à utilização da Web como uma razão importante para o não-uso do sítio. A autora ainda complementa que sessões tutoriais sobre o uso da Web, ou do sítio em questão podem vir a auxiliar os estudantes a desenvolver o sentimento de conforto com o uso do meio ${ }^{28}$.

\subsection{As expectativas dos alunos no que diz respeito à utilização do sítio}

Com o intuito de conhecer as expectativas dos alunos no que diz respeito à utilização do sítio disponibilizado na disciplina em foco, a seguinte pergunta também fez parte do questionário por eles respondido quando realizaram o cadastro no sítio: "Você acredita que a 
implantação de material suplementar para esta disciplina, via Internet, pode ajudar o seu desempenho?" "De que forma?". Quase a totalidade dos estudantes $(93,5 \%)$ afirmou acreditar que a implantação de material suplementar para a disciplina em foco, via Internet, poderia ajudar no seu desempenho na disciplina. Foram também obtidas 23 respostas dissertativas $(71,8 \%)$ ao segundo questionamento que complementa a primeira questão. Estas respostas foram categorizadas visando a realização de ajustes posteriores no sítio que viessem contemplar as expectativas dos alunos e o seu aperfeiçoamento.

A Tabela 2 apresenta as respostas obtidas na primeira coluna e a categoria a que cada uma delas pertence na segunda coluna. Cabe esclarecer que as três últimas respostas apresentadas na Tabela 2, aparentemente sem qualquer sentido frente ao questionamento colocado, não foram categorizadas. Foram estabelecidas 5 categorias de respostas que expressam as formas como os alunos esperavam que o sítio os auxiliasse: $\bullet$ categoria $\mathrm{A}=$ na facilidade de comunicação/interação entre os envolvidos no desenvolvimento da disciplina (alunos, professores, estagiários $\mathrm{PAE}$ ); • categoria $\mathrm{B}=$ na facilidade de acesso a informações e de resolução de dúvidas; • categoria $\mathrm{C}$ = na confecção e no processo de envio dos relatórios; - categoria $\mathrm{D}$ = no oferecimento de meios que tornassem mais cômoda a realização de tarefas da disciplina; - categoria $\mathrm{E}=$ no oferecimento de meios que tornassem as aulas mais dinâmicas e didáticas. 
Tabela 2: Expectativas iniciais dos alunos no que diz respeito à utilização do sítio. A coluna Respostas lista as respostas dadas à questão dissertativa presente no questionário de caracterização e as colunas Categorias mostram em que categoria cada resposta se encaixa.

\section{RESPOSTAS}

Comunicação e facilidade para buscas a respostas para dúvidas.

Um conforto maior, e certamente um acomodo maior.

Na familiarização com o conteúdo da prática que será realizada no laboratório.

Relacionado a atender minhas duvidas, enviar relatórios, etc.

Facilita a interação entre aluno, professor.

Disponibilização de mais informações, que podem ser utilizadas por várias pessoas de varias instituições.

Tornando mais dinâmico e didático às aulas e de certa forma poupando tempo com os relatórios.

Orientando como devem ser feitos os relatórios ou outras informações. Etc...

Talvez para tirar dúvidas quanto a relatórios, se os resultados não estão tão fora, entre outros aspectos.

Para qualquer trabalho, é importante obter o maior número de dados possível, a fim não copiar trechos.

Achar artigo mais rápido e o necessário sem blablabla.

Aumentando meus conhecimentos em química analítica.

Facilita a comunicação e integração entre docentes e discentes.

Seria um local onde estariam informações confiáveis e que podem nos poupar tempo, entre outras vantagens.

Poderá facilitar minha pesquisa para elaboração de relatórios ou meu estudo da disciplina.

Facilitando a entrega de relatórios e a troca de informações com outros alunos. Auxiliando na elaboração dos relatórios e facilitando o estudo para as provas.

Agilidade no processo de entrega de relatórios; já que sempre a pró-aluno está sem folhas para impressão.

No auxílio junto aos relatórios, à distância.

Na maneira mais rápida de troca de informações.

Como está sendo feito...

Facilitando o acesso.

Nenhuma!!!!

\section{CATEGORIAS}

A B C D E

- $\bullet$

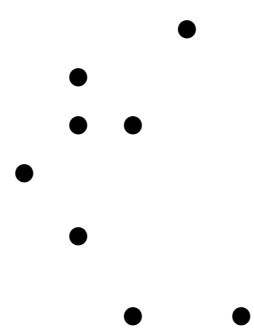

1

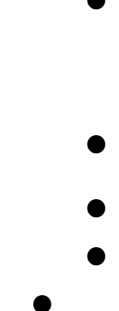

$\bullet$
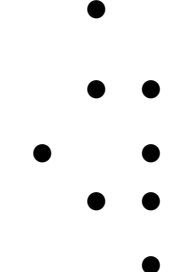

A Figura 18 mostra o gráfico de frequiência com que cada uma das categorias foi mencionada pelos alunos e sintetiza as expectativas dos mesmos com relação à forma com que o sítio poderia aumentar seu desempenho na disciplina. Duas categorias foram mais freqüentemente citadas e correspondem respectivamente à categoria $\mathrm{B}$ que diz respeito à facilidade de acesso a informações e de resolução de dúvidas, e à categoria C, que diz respeito à confecção e ao processo de envio dos relatórios. 

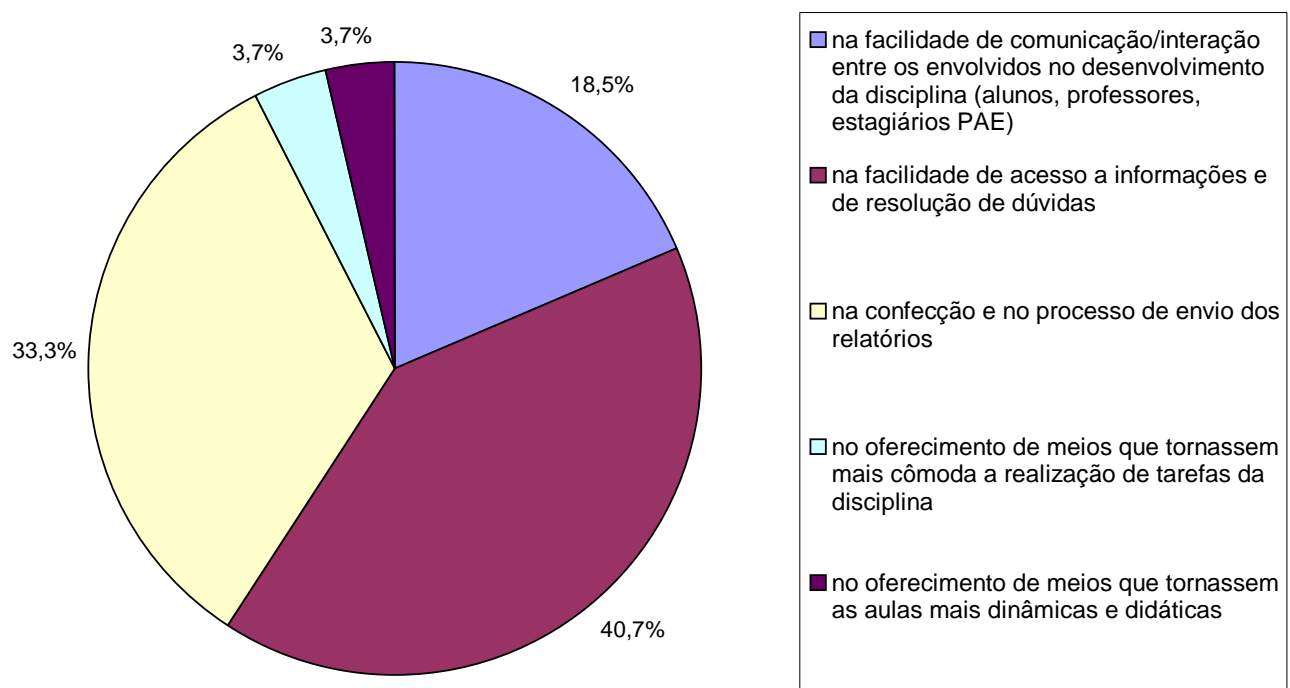

Figura 18: Gráfico de frequiência de respostas dadas a cada categoria estabelecida para as expectativas dos alunos.

No que diz respeito às expectativas dos alunos quanto à facilidade de acesso a informações e auxílio na resolução de dúvidas, estas já haviam sido consideradas na elaboração do sítio. Conforme mencionamos anteriormente, bases teóricas de projeto gráfico e diagramação foram utilizadas na elaboração das páginas do sítio visando facilitar o processo de busca e acesso às informações disponíveis. Ainda neste foco, o bate-papo e fórum de discussão foram disponibilizados de forma a facilitar o processo de resolução de dúvidas. A segunda expectativa mais citada pelos estudantes, encontra-se em sintonia com a proposta colocada em prática por Olivier e colaboradores ${ }^{79}$ e descrita no artigo intitulado "WebMark a fully automated method of submission, assessment, grading, comentar for laboratory pratical scripts". Neste trabalho, o autor desenvolve uma ferramenta Web, chamada WebMark, destinada ao envio e avaliação automática de relatórios padronizados. Esta ferramenta permite que os estudantes enviem os resultados, obtidos em aulas práticas, via formulários em páginas Web e obtenham notas e comentários de possíveis erros cometidos. Os autores identificam os seguintes benefícios com o uso da ferramenta: recebimento pelo 
aluno, quase instantaneamente, de comentários detalhados sobre os cálculos apresentados no relatório; diminuição do tempo de avaliação de relatórios pelos professores; certeza do envio do relatório pelo próprio aluno na data marcada para o recebimento.

Frente aos resultados positivos obtidos por Olivier e colaboradores ${ }^{79}$, e buscando suprir a expectativa dos alunos, desenvolvemos uma página, após o lançamento do sítio, que denominamos de página de Envio de Relatório e a sua utilização tornou-se possível a partir da quinta prática. Se considerarmos que antes da aplicação do sistema, 33,3\% dos alunos cadastrados esperavam poder utilizar uma ferramenta que os auxiliasse na construção de relatórios, e depois de sua publicação, 75\% dos alunos cadastrados tenham feito uso de suas funcionalidades, acreditamos que não apenas a ferramenta de Envio de Relatório, mas que o sítio, como um todo, tenha ido ao encontro das expectativas de grande parte dos alunos.

\subsection{Análise do uso do sítio de Internet pelos alunos}

Conforme mencionamos anteriormente, parte das pesquisas reportadas na literatura analisa o emprego dos recursos educacionais disponíveis na Internet a partir da aplicação de questionários aos seus usuários. No trabalho de Dori e Barak ${ }^{26}$, por exemplo, a forma de utilização do sítio foi investigada a partir da aplicação de questionários aos estudantes. Os autores solicitaram que os alunos especificassem o número de vezes que haviam acessado o sítio e o objetivo de cada acesso. As principais motivações que levaram ao maior número de acessos foram: obtenção de solução para questões apresentadas nas tarefas da disciplina, obtenção de exercícios para resolução em casa e leitura de materiais relacionados ao conteúdo do curso. 
Outra parte dos trabalhos reportados na literatura se dedica a analisar, por contagem, o uso dos recursos disponíveis na Internet. Este procedimento foi adotado no trabalho de Hall e colaboradores $^{3}$ : os autores disponibilizaram exercícios via Web que deveriam ser respondidos pelos alunos. Caso um aluno respondesse um dos exercícios incorretamente, ele receberia uma "segunda chance", também via Web, para que tentasse melhorar sua nota. Neste caso os autores analisam o emprego deste recurso pela contagem do número de respostas corretas na primeira e na segunda tentativa, e pelo número de estudantes que utilizaram a ferramenta em ambas as chances. Ao final do semestre, os autores concluíram que mais de $90 \%$ dos estudantes haviam utilizado a ferramenta ao menos uma vez e que os estudantes que haviam terminado a disciplina com as maiores notas haviam utilizado mais vezes sua "segunda chance" que os estudantes que terminaram o semestre com notas menores.

A estratégia de monitorar a navegação dos alunos também é adotada por alguns pesquisadores. Crippen e Brooks ${ }^{77}$ se dedicaram a investigar a maneira que os estudantes acessaram um sítio que disponibilizava questões elaboradas com o intuito de facilitar o aprendizado de química descritiva. Os autores gravaram informações importantes sobre o acesso dos alunos: hora e endereço, itens enviados, respostas submetidas ao sítio e tutoriais requisitados. Fizeram isto visando a obtenção de informações capazes de indicar padrões de uso do sítio pelos estudantes. Weaver ${ }^{28}$, por sua vez, contou com o auxílio dos registros armazenados no servidor, que fornecem o número total de visitas feitas pelos alunos a uma determinada página do sítio. Estas informações permitiram, que a autora, construísse um gráfico que relaciona os acessos totais a um tópico versus os tópicos oferecidos pelo sítio (na mesma ordem em que são abordados em sala).

No trabalho que aqui apresentamos, o uso do sítio de Internet foi monitorado a partir da inserção de uma ferramenta escrita em linguagem JAVA, explicada no capítulo 
Construção do Sítio de Internet, nas seguintes páginas: Conteúdo Teórico, Glossário, Envio de Relatório e Página de Rosto. A ferramenta de monitoramento da navegação foi inserida apenas nas páginas do sistema por nós desenvolvido, pois sua inserção no bate-papo ou nas páginas do fórum seria impossível devido ao fato de não possuirmos acesso ao código-fonte do bate-papo, e também porque a linguagem PHP (em que foram escritas as páginas do fórum) não pode ser combinada com a linguagem JAVA (em que foi escrita a ferramenta).

Os dados de navegação dos alunos foram obtidos a partir de informações armazenadas pelo próprio sítio. Verificamos que 560 acessos foram gravados durante o semestre. Vale relembrar que estes dados se referem apenas às páginas que contém a ferramenta de mapeamento, ou seja, não incluem os acessos ao módulo administrador, às páginas do fórum de discussão ou do bate-papo.

A Figura 19 mostra o número de acessos a cada um dos tipos de páginas monitoradas e indica a página de Rosto como sendo a mais acessada, seguida pelas páginas de Conteúdo, Envio de Relatório, Contato e Glossário. 


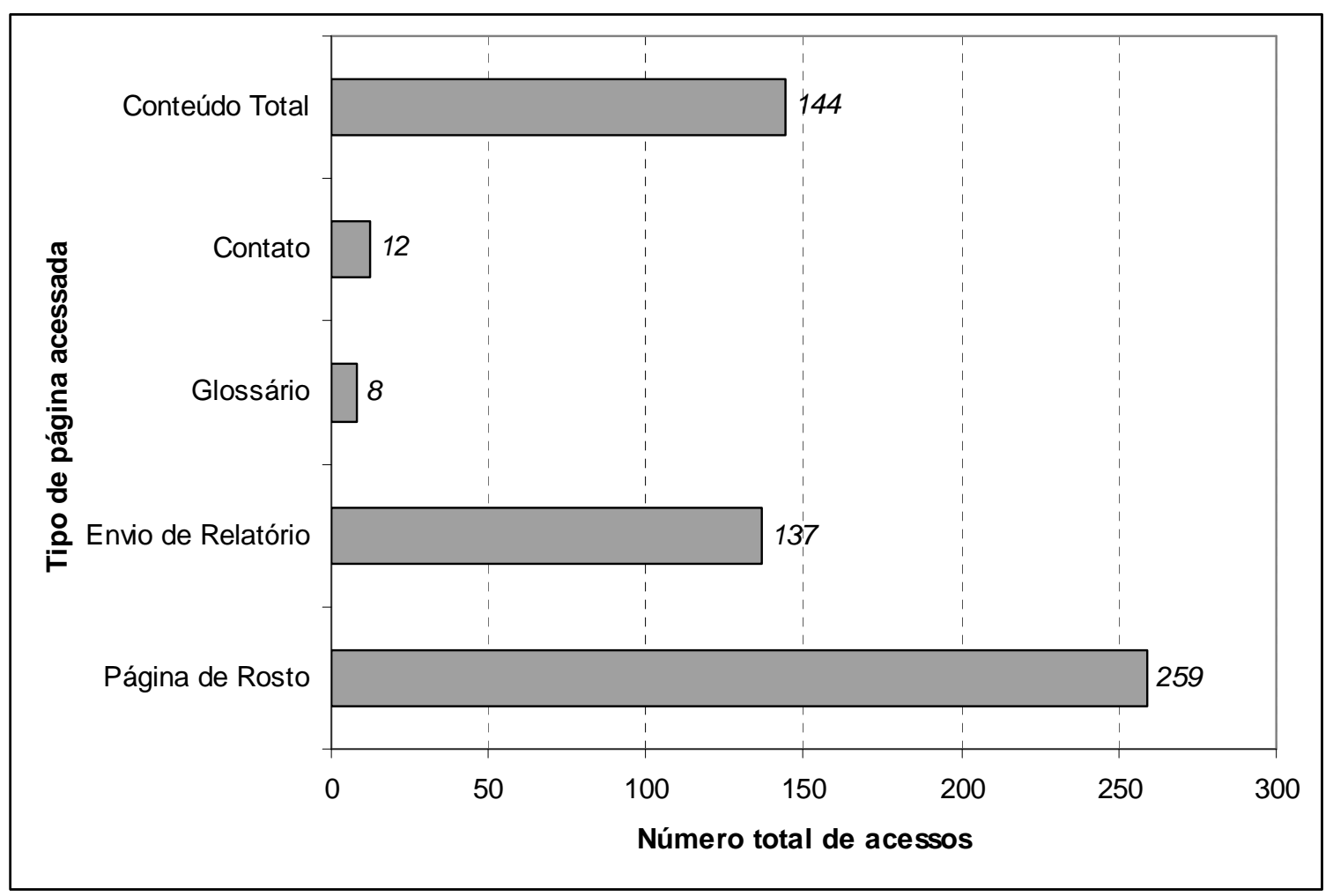

Figura 19: Gráfico de acessos totais às páginas mapeadas do sistema. O valor Conteúdo Total reflete a soma dos acessos totais às páginas que compõem o conteúdo teórico (Algarismos Significativos, Análise Gravimétrica e Análise Volumétrica). Glossário, Envio de Relatório, Contato e página de Rosto refletem acessos a páginas individuais.

A seguir discutimos os acessos a cada uma das páginas monitoradas e estabelecemos relações entre os resultados obtidos e as informações disponíveis na literatura, provenientes de outras pesquisas de mesmo teor.

\subsubsection{Acessos à página de Rosto}

A Figura 10 ilustra a página de Rosto do sistema. Esta página é a primeira a ser exibida no acesso ao sistema e traz informações relevantes à disciplina na forma de notícias adicionadas por qualquer administrador. A partir da análise da Figura 19, verificamos um elevado número de acessos a esta página. Cabe esclarecer que este elevado número de acessos se deve ao fato desta ser exibida sempre após o acesso ao sistema, ao envio de e-mail ou relatório ao sítio. Assim, sendo esta a página para onde o usuário é redirecionado após 
qualquer interação com o sítio, não é surpreendente que o número de acessos a ela supere os demais.

\subsubsection{Acessos à página de Envio de Relatório}

A Figura 16 ilustra a Página de Envio de Relatório. Conforme mencionamos anteriormente, esta página foi desenvolvida após a publicação do sítio, estando disponível para um total de 7 práticas. No entanto, os alunos tiveram permissão para enviar os relatórios atrasados fazendo uso da página. Verificamos que 84 relatórios, de um total de 208 relatórios esperados, caso todos os alunos tivessem feito uso da ferramenta de envio na entrega dos relatórios das 7 práticas, foram enviados através do sistema aos docentes responsáveis pela disciplina. Este número perfaz um total de 40,4\% de todos os relatórios que foram enviados ao professor. Ou seja, os 124 relatórios restantes foram recebidos pelos docentes no formato tradicional, em papel.

Com relação ao número de relatórios que foram enviados, via Web, por alunos de cada uma das turmas, verificamos que 76 dos 84 relatórios $(90,5 \%)$ que foram enviados desta maneira, foram provenientes de alunos da Turma 1, enquanto que apenas $9,5 \%$ foram enviados por alunos da Turma 2. Este número baixo de envio de relatórios por alunos da Turma 2 talvez possa ser justificado pelo fato de termos atuado como estagiário PAE da Turma 1 e, através de comentários ocasionais em laboratório, tenhamos fomentado o uso destas ferramentas, ainda que de forma não planejada. Conforme mencionamos anteriormente, o sítio foi apresentado em ambas as turmas e nenhuma menção posterior sobre sua utilização foi feita pelos professores. Provavelmente, o fato dos alunos terem conhecimento da realização da nossa pesquisa, associado à nossa interação com os alunos da Turma 1, tenha os estimulado a utilizar o sítio em maior freqüência que os alunos da Turma 2. Nesta perspectiva, Paulisse e Polik ${ }^{40}$ frisam a importância da relação existente entre o estímulo à utilização das 
ferramentas pelos professores das disciplinas nas quais são empregadas e a freqüência com que elas são utilizadas pelos alunos. No trabalho desenvolvido por eles sobre a utilização do Chemboard, mencionado anteriormente, em várias turmas no Hope College, EUA, esta relação ficou claramente estabelecida.

O gráfico da Figura 20 sintetiza as informações sobre os relatórios enviados para cada uma das práticas realizadas. Uma listagem completa das práticas executadas durante o semestre encontra-se na Tabela 3. Conforme mencionamos anteriormente, a ferramenta só ficou disponível para um total de 7 práticas, a partir da quinta prática, indicada pelo número 5 no eixo das abscissas até a prática 11 , indicada pelo número 11 no mesmo eixo.

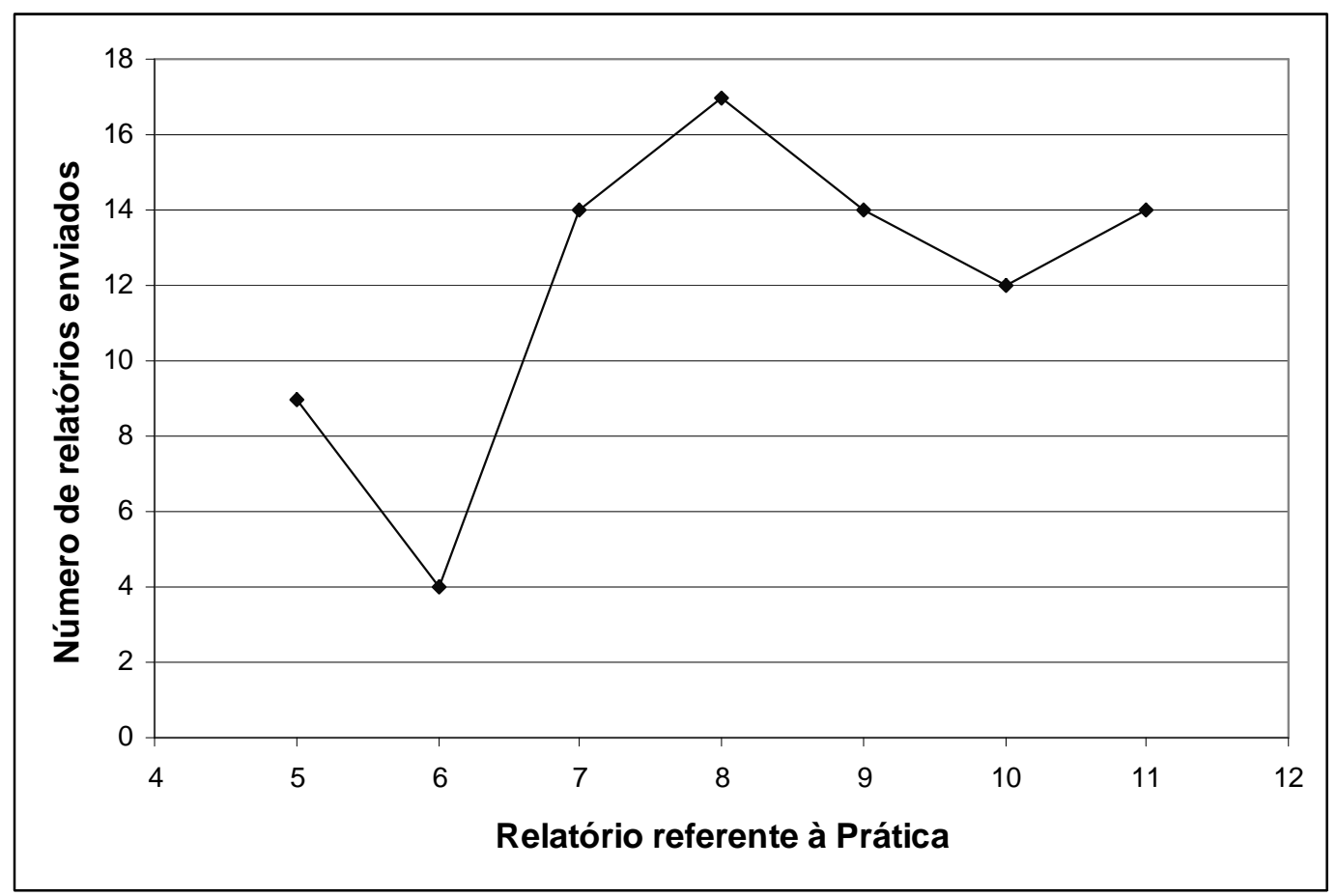

Figura 20: Gráfico do número de relatórios enviados em relação à prática realizada. $\mathrm{O}$ número 5 no eixo das abscissas representa a prática 5 e o número 11 representa a prática 11 . $\mathrm{O}$ eixo das ordenadas representa o número total de relatórios enviados para cada uma das práticas.

Verificamos inicialmente um decréscimo no número de relatórios enviados entre as práticas 5 e 6 . Este decréscimo pode ser justificado pelo fato do relatório da prática 6 conter 
gráficos de titulação. Entendemos a preferência dos alunos na entrega deste relatório da maneira tradicional (papel) visto que a inserção de imagens via ferramenta HTMLArea exige que a imagem esteja disponível na Web; fato que dificultou a construção do relatório, pelos alunos, em formato digital. Ademais, o número reduzido de relatórios enviados para a prática 6 se deve ao fato do mesmo ter sido entregue por duplas de alunos, diferentemente dos demais que foram entregues individualmente. A partir da prática 6 notamos um aumento no número de relatórios enviados. Se considerarmos a média de relatórios enviados para as práticas 7 a 11, podemos afirmar que 14,2 relatórios foram enviados em média neste intervalo de práticas. Como os relatórios destas práticas são individuais, em média, 14 alunos (43,75\%) utilizaram a ferramenta neste período. Os dados apresentados na Figura 20 mostram que o uso da ferramenta foi se consolidando no decorrer do semestre, sugerindo a sua boa aceitação.

Tabela 3: Tabela das práticas executadas durante o semestre.

\begin{tabular}{l|l} 
No. Da Prática & \multicolumn{1}{c}{ Título da prática } \\
\hline Prática 1 & Erros \\
\hline Prática 2 & Gravimetria - Determinação de Água de Hidratação em Sólidos \\
\hline Prática 3 & Gravimetria - Determinação de Ferro \\
\hline Prática 4 & Gravimetria - Determinação de Níquel \\
\hline Prática 5 & Preparação de Soluções e Titulação Ácido-Base - Alcalimetria \\
\hline Prática 6 & Titulação Ácido-base - Acidimetria - Curvas de titulação \\
\hline Prática 7 & Volumetria de Precipitação \\
\hline Prática 8 & Volumetria de Oxidação-Redução (permanganato) \\
\hline Prática 9 & Volumetria de Oxidação-Redução (dicromato) \\
\hline Prática 10 & Volumetria de Oxidação-Redução - Determinações lodométricas \\
\hline Prática 11 & Volumetria de Complexação - EDTA \\
\hline Prática 12 & Reposição
\end{tabular}

No que diz respeito à efetividade da ferramenta, todos os relatórios enviados pelos alunos foram recebidos de forma apropriada, com formatação correta, inclusive no que diz respeito à apresentação de sobrescritos, subscritos e tabelas. Esta propriedade do sítio é digna de nota, pois, conforme afirmam Paulisse e Polik ${ }^{40}$, a possibilidade de inserção de formatação (sobrescritos, subscritos, etc) é extremamente importante em documentos que veiculam 
informações sobre conteúdos de química, nos quais a apresentação de fórmulas e de tabelas, por exemplo, é muito constante.

Durante o semestre, vários alunos fizeram comentários orais, e pelo fórum de discussão, sobre a inquietação que sentiam ao enviar o relatório e não receberem qualquer confirmação explícita sobre o correto recebimento do mesmo. Na realidade, caso o recebimento de um relatório enviado fosse processado com sucesso, o aluno era redirecionado à página de Rosto. Caso o recebimento não fosse bem-sucedido, o aluno era reenviado à página de Envio de Relatório. Ainda assim, achamos conveniente desenvolver durante o semestre uma página de confirmação exibida a cada envio de relatório.

Embora vários trabalhos reportados na literatura tratem de iniciativas que visam o melhoramento do ensino de química em disciplinas experimentais ${ }^{7,11,79}$ encontramos uma única menção sobre a utilização de ferramenta similar a que desenvolvemos para o envio de relatório no trabalho de Olivier e colaboradores ${ }^{79}$. Como mencionado anteriormente, o autor desenvolveu a ferramenta WebMark destinada ao envio e avaliação automática de relatórios padronizados. Os dados obtidos pelos estudantes em aulas práticas são inseridos em uma página Web e, após envio, notas e comentários são retornados ao aluno quase que instantaneamente. Os autores perceberam como um dos pontos positivos do trabalho o fato de aproximadamente $20 \%$ dos estudantes afirmarem gostar da flexibilidade de poder enviar o relatório de qualquer computador conectado à Internet. Assim como proposto por Olivier e colaboradores $^{79}$, nossa intenção ao disponibilizarmos a ferramenta aos estudantes foi a de prover um meio mais fácil para a entrega do relatório, visto que, em nosso Instituto, a maioria dos estudantes de graduação possui dificuldades na impressão deste tipo de material e o envio eletrônico do relatório minimiza este problema. 


\subsubsection{Acessos à página de Glossário}

A Figura 17 ilustra a página de Glossário. Foram inseridos nesta página 16 verbetes reproduzidos no Anexo D desta dissertação, 8 verbetes relacionados à área Algarismos Significativos, 4 verbetes relacionados à área Análise Gravimétrica e 4 verbetes relacionados a Análise Volumétrica. Os verbetes são reproduzidos sem separação da área a que pertencem e em ordem alfabética, permitindo ao estudante verificar verbetes de áreas diferentes em um mesmo acesso.

O número baixo de acessos à página de Glossário, apenas 8 durante todo o semestre, sugere a pouca utilidade percebida pelos estudantes para esta ferramenta.

\subsubsection{Acessos à página de Contato}

A Figura 21 ilustra a página de Contato. Apenas 12 acessos foram computados para esta página (envio de e-mail). Todas as mensagens que foram enviadas pelos alunos ao estagiário da Turma 1 versavam apenas sobre a confirmação de informações já transmitidas em aula ou via sítio. Não foram recebidas mensagens relacionadas ao conteúdo ministrado na disciplina. A pouca utilização da Página de Contato pelos alunos com este objetivo pode ser justificada tendo em vista a existência no sítio de um fórum de discussão através do qual dúvidas sobre tópicos ministrados na disciplina e sobre práticas realizadas podiam ser inseridas para que os professores e/ou estagiários respondessem oportunamente. A maneira como o fórum foi empregado pelos alunos será discutida posteriormente. 


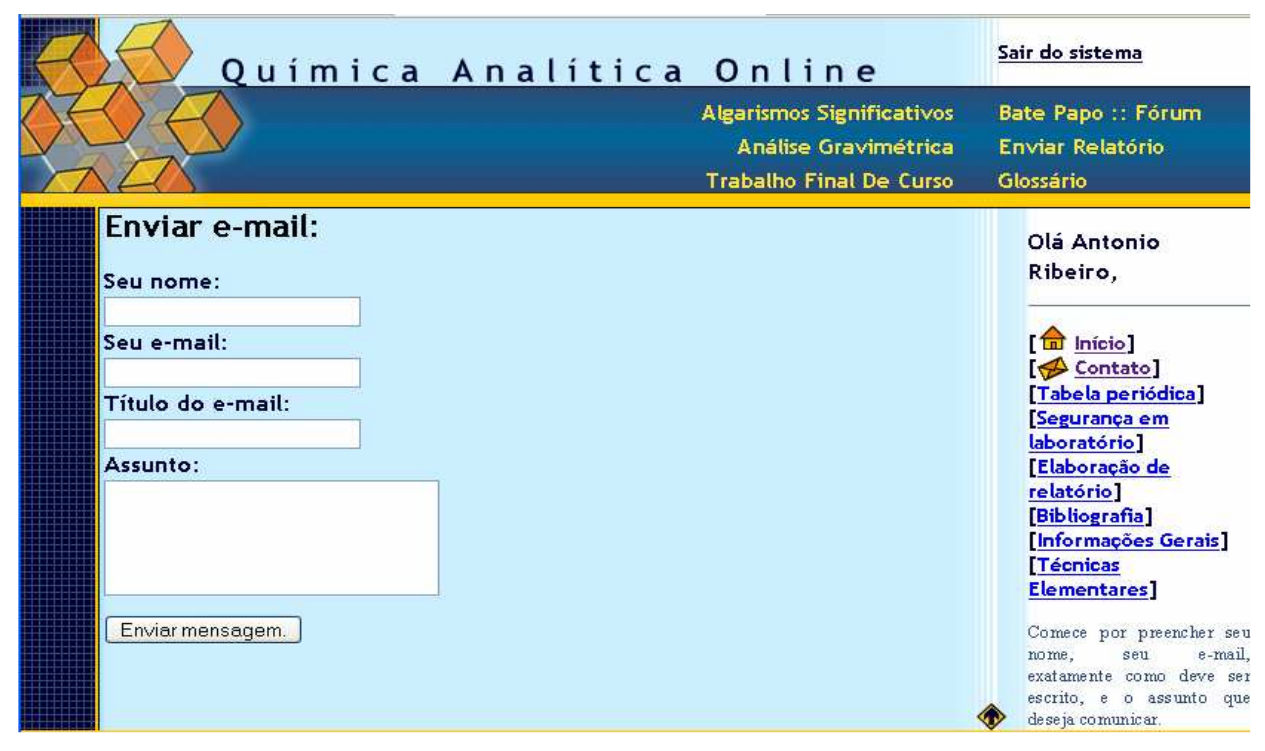

Figura 21: Representação da página de contato do sistema.

Trabalhos reportados na literatura enfatizam a preferência dada pelos estudantes às interações face-a-face com colegas, estagiários e professores em comparação às interações estabelecidas via e-mail ou fórum eletrônico ${ }^{26,32,40}$. Aparentemente, até mesmo em disciplinas delineadas com o objetivo de fomentar o aprendizado colaborativo e a comunicação entre os estudantes, a interação face-a-face é privilegiada. Um exemplo deste formato de disciplina encontra-se relatado no artigo intitulado "Organic chemistry online: building collaborative learning communities through eletronic communication tools" de Glaser e Poole ${ }^{32}$. Segundo os autores, embora as tarefas destinadas aos estudantes exigissem a realização de trabalhos em grupo, e no sítio da disciplina existissem recursos para interação entre eles via comunicação eletrônica, após a formação dos grupos a maioria dos estudantes continuou a realizar as atividades exigidas pelo professor através de encontros face-a-face. Em contrapartida, em cursos nos quais os estudantes estão alocados em universidades separadas geograficamente, verifica-se o uso mais intenso de ferramentas de contato ${ }^{76}$. Investigações sobre a forma como os estudantes e professores interagem em cursos desta natureza foram recentemente divulgadas por Slocum e colaboradores ${ }^{82}$. 
Entre os trabalhos reportados na literatura destacamos o de Tissue e colaboradores ${ }^{11}$, no qual os autores desenvolvem estudo sobre o uso de uma ferramenta Web em uma disciplina de laboratório de Análise Instrumental. Assim como foi por nós observado, os estudantes fizeram pouquíssimo uso da ferramenta de contato durante a realização da disciplina. Os autores concluem que estas ferramentas não costumam se mostrar efetivas em cursos de laboratório, no qual o contato face-a-face entre os envolvidos no processo de ensino-aprendizagem, via de regra, é favorecido. O trabalho de Paulisse e Polik ${ }^{40}$ também apresenta conclusões que corroboram a colocação de Tissue ${ }^{11}$. Segundo estudo por eles realizado, mencionado anteriormente, sobre o uso do ChemBoard em várias disciplinas do departamento de Química do Hope College, EUA, a opção pela comunicação face-a-face com os professores era escolhida pelos alunos, em prejuízo da comunicação eletrônica, principalmente em disciplinas nas quais o professor podia ser abordado com facilidade.

\subsubsection{Acessos às páginas de Conteúdo}

Antes de iniciarmos a discussão sobre o acesso dos alunos às páginas de Conteúdo, faz-se necessário apresentar uma breve descrição sobre o processo de construção do sítio e sobre a forma como os conteúdos foram nele inseridos.

Existe uma estreita relação entre a produção da primeira versão do sítio e as atividades por nós desenvolvidas quando cursamos a disciplina SCE5811-5 - Hipermídia, no primeiro semestre de 2004. A disciplina, oferecida pelo programa de pós-graduação do Instituto de Ciências Matemáticas e Computação da Universidade de São Paulo, apresenta os fundamentos da tecnologia de hipermídia, abordando questões relevantes à arquitetura, modelagem, especificação, construção e usabilidade de aplicações hipermídia de modo geral, e daquelas que manipulam hiperdocumentos estruturados para a WWW de modo particular $^{83}$. Como método de avaliação, os alunos matriculados devem se compor em grupos a fim de 
construir uma aplicação hipermídia baseada em linguagem Java. A primeira versão do sítio teve como base a aplicação desenvolvida nesta disciplina. No entanto, após sua conclusão, fez-se ainda necessária a implementação de algumas modificações nesta versão, para que o sítio assumisse as características necessárias para aplicação na disciplina de Laboratório de Química Analítica Quantitativa. Desta forma, não tivemos tempo hábil para disponibilizar o sítio na sua versão definitiva aos alunos no início do segundo semestre letivo de 2004.

$\mathrm{Na}$ data do seu lançamento, o sítio contava com quase toda a programação apresentada no capítulo Construção do Sítio de Internet desta dissertação, mas continha em sua base de dados apenas alguns tópicos relacionados à área de Algarismos Significativos. Os outros tópicos abordados na disciplina foram adicionados conforme o andamento da mesma.

Considerando apenas os acessos às páginas de conteúdo, fez-se possível elaborar um gráfico que mostra a organização hierárquica do conteúdo presente no sítio em função do número de acessos a cada um deles. Este gráfico encontra-se ilustrado na Figura 22 e os conteúdos, aí indicados na forma numérica, são descritos na Tabela 4. Cabe esclarecer que os tópicos que apresentam a letra "P" se referem aos roteiros das práticas entregues em formato impresso aos alunos no início do semestre e disponibilizados no sítio em formato digital. Os tópicos que não encontram correspondência na Tabela 4 não foram inseridos no sítio. 


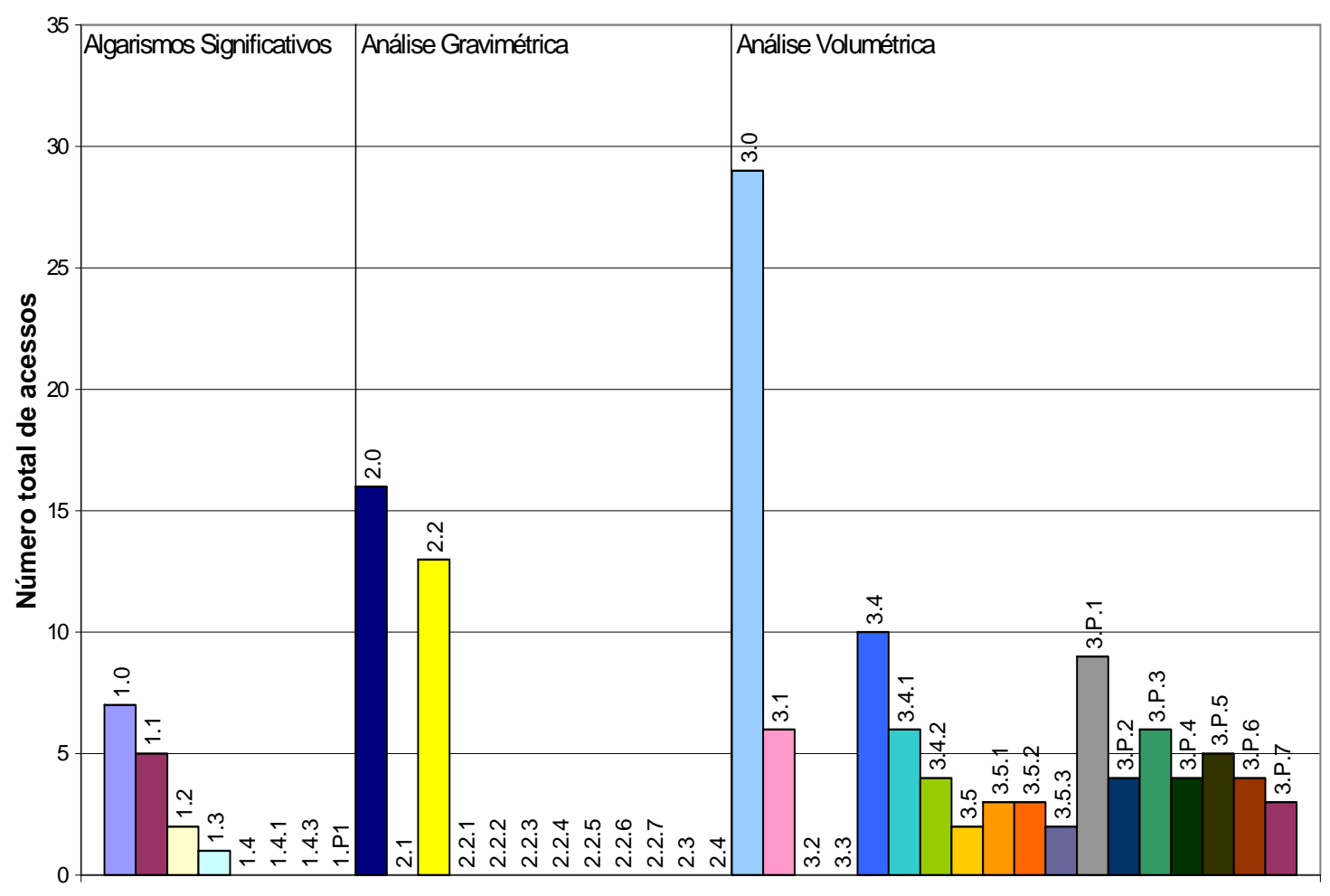

Tópicos oferecidos pelo sistema

Figura 22: Acessos totais ao sistema organizado na forma hierárquica do conteúdo. Cada barra vertical corresponde ao numero absoluto de acessos à página em questão. Os tópicos representados que não possuem acessos computados se referem a páginas que não foram acessadas ou não estavam disponíveis aos alunos. O título de cada tópico é reproduzido na Tabela 4. As separações verticais indicam as divisões do conteúdo nas áreas correspondentes.

Tabela 4: Numeração e títulos dos tópicos referentes ao conteúdo teórico oferecido pelo sistema. O número total de acessos a cada tópico pode ser observado na Figura 22.

\begin{tabular}{|c|l|c|l|}
\hline 1.0 & Sinais analíticos e verdades estatísticas. & $\mathbf{2 . 3}$ & $\begin{array}{l}\text { Precipitação em meio homogêneo na análise } \\
\text { gravimétrica. }\end{array}$ \\
\hline $\mathbf{1 . 1}$ & $\begin{array}{l}\text { Algarismos significativos e figuras } \\
\text { significativas em química analítica. }\end{array}$ & $\mathbf{2 . 4}$ & $\begin{array}{l}\text { Fatores que afetam a formação e solubilidade de } \\
\text { precipitados na análise gravimétrica. }\end{array}$ \\
\hline $\mathbf{1 . 2}$ & $\begin{array}{l}\text { Definições e terminologia na análise } \\
\text { estatística de resultados analíticos. }\end{array}$ & $\mathbf{3 . 0}$ & A auto-protonação da água e a definição de pH. \\
\hline $\mathbf{1 . 3}$ & Tipos de erros em resultados experimentais. & $\mathbf{3 . 1}$ & $\begin{array}{l}\text { Reações e cálculos de pH de ácidos e bases } \\
\text { fortes. }\end{array}$ \\
\hline $\mathbf{1 . 4}$ & $\begin{array}{l}\text { Precisão, reprodutibilidade e repetibilidade } \\
\text { de resultados. }\end{array}$ & $\mathbf{3 . 4}$ & Sistemas tampão. \\
\hline $\mathbf{1 . 4 . 1}$ & $\begin{array}{l}\text { Estimativa do desvio padrão e de } \\
\text { confiabilidade analítica. }\end{array}$ & $\mathbf{3 . 4 . 1}$ & O efeito tampão. \\
\hline $\mathbf{1 . 4 . 3}$ & $\begin{array}{l}\text { Exatidão erro médio absoluto e erro médio } \\
\text { relativo de resultados. }\end{array}$ & $\mathbf{3 . 4 . 2}$ & O preparo de uma solução tampão. \\
\hline $\mathbf{1 . P 1}$ & Prática 1: Erros. & $\mathbf{3 . 5}$ & Introdução às reações de complexação. \\
\hline $\mathbf{2 . 0}$ & Teoria da análise gravimétrica: conceituação. & $\mathbf{3 . 5 . 1}$ & Efeitos que controlam a formação de complexos. \\
\hline $\mathbf{2 . 1}$ & A estequiometria em cálculos gravimétricos. & $\mathbf{3 . 5 . 2}$ & Tipos de ligantes formadores de complexos. \\
\hline $\mathbf{2 . 2}$ & O fator gravimétrico. & $\mathbf{3 . 5 . 3}$ & Substituição de ligantes e mascaramento. \\
\hline $\mathbf{2 . 2 . 1}$ & Atividades iônicas. & $\mathbf{3 . P . 1}$ & $\begin{array}{l}\text { Prática 5: Preparo de soluções e titulação ácido- } \\
\text { base: alcalimetria }\end{array}$ \\
\hline
\end{tabular}




\begin{tabular}{|l|l|l|l|}
\hline 2.2.2 & Reações de complexação. & 3.P.2 & Prática 6: Titulação ácido-base: acidimetria \\
\hline 2.2.3 & Efeito de substâncias indiferentes. & 3.P.3 & $\begin{array}{l}\text { Prática 7: Ácidos, bases, sistemas tampão e } \\
\text { indicadores. }\end{array}$ \\
\hline 2.2.4 & Acidez e pH. & 3.P.4 & Prática 8: Volumetria de precipitação. \\
\hline 2.2.5 & Temperatura. & 3.P.5 & Prática 9: Volumetria de oxidação-redução. \\
\hline 2.2.6 & Solventes. & 3.P.6 & $\begin{array}{l}\text { Prática 10: Volumetria de oxidação-redução: } \\
\text { Determinações iodométricas. }\end{array}$ \\
\hline 2.2.7 & $\begin{array}{l}\text { Tamanho de partículas e velocidade de } \\
\text { precipitação. }\end{array}$ & 3.P.7 & Prática 11: Volumetria de complexação: EDTA \\
\hline
\end{tabular}

Pode-se perceber a partir da análise do gráfico apresentado na Figura 22 um aumento no número de acessos entre os tópicos 1.0, 2.0 e 3.0, que dizem respeito, respectivamente a: Sinais analíticos e verdades estatísticas (área de Algarismos Significativos), Teoria da análise gravimétrica: conceituação (área de Análise Gravimétrica), e A auto-protonação da água e a definição de pH (área de análise Volumétrica). Assim, os alunos utilizaram o sítio com maior freqüência no estudo da área final do programa da disciplina (Análise Volumétrica), visitando todo o material disponível que compreende os tópicos 3.0 a 3.P.7, o que poderia sugerir, ao longo do semestre, a consolidação do mesmo como uma ferramenta de suporte aos estudantes. Se compararmos ainda os acessos feitos aos conteúdos da área de Análise Volumétrica frente as práticas disponíveis para a mesma área podemos afirmar que praticamente a mesma importância foi dada pelos estudantes tanto no acesso aos conteúdos quanto no acesso às práticas disponibilizadas para a área de Análise Volumétrica. Ainda com relação ao tema, Paulisse e Polik ${ }^{40}$ afirmam que a freqüência com que determinados tópicos são acessados pelos estudantes é dependente da importância percebida por eles no que diz respeito aos mesmos. Embora esta consideração seja importante, acreditamos que, no nosso caso ela não possa ser aplicada em plenitude, uma vez que todo o conteúdo teórico do nosso sítio não se encontrava inserido desde o seu lançamento. Isto pode ter prejudicado o acesso aos tópicos das áreas Algarismos Significativos e Análise Gravimétrica, visto que alguns tópicos relacionados a estas áreas ainda eram inseridos no sítio durante as práticas de Análise Volumétrica. Assim, embora a afirmação de Paulisse e Polik ${ }^{40}$ possa nos levar a crer que, em nosso caso, o maior número de acessos aos tópicos de Análise Volumétrica sugere uma maior 
importância percebida pelos estudantes para esta área de estudo, as variáveis envolvidas impedem que se alcance uma conclusão a respeito.

Para que o leitor faça uma interpretação correta dos dados apresentados na Figura 22, é imprescindível que tome conhecimento do caráter modular do sítio. A Figura 23 tem como objetivo explicar este caráter, através da apresentação do diagrama geral de navegação nos conteúdos do sistema. Os círculos azuis representam as três áreas do nosso sistema e os quadrados em verde os tópicos oferecidos por cada uma das áreas. Dentro de cada área o internauta pode navegar livremente pelos tópicos, ou seja, caso o internauta resolva estudar os tópicos oferecidos na área 2, ele pode acessar os tópicos, neste caso "c" e "d", da forma como preferir. Caso o internauta esteja no tópico "e" da área 3 e deseje acessar o tópico "d", a sua única possibilidade é acessar primeiramente a área 2 e então prosseguir ao tópico “d”.

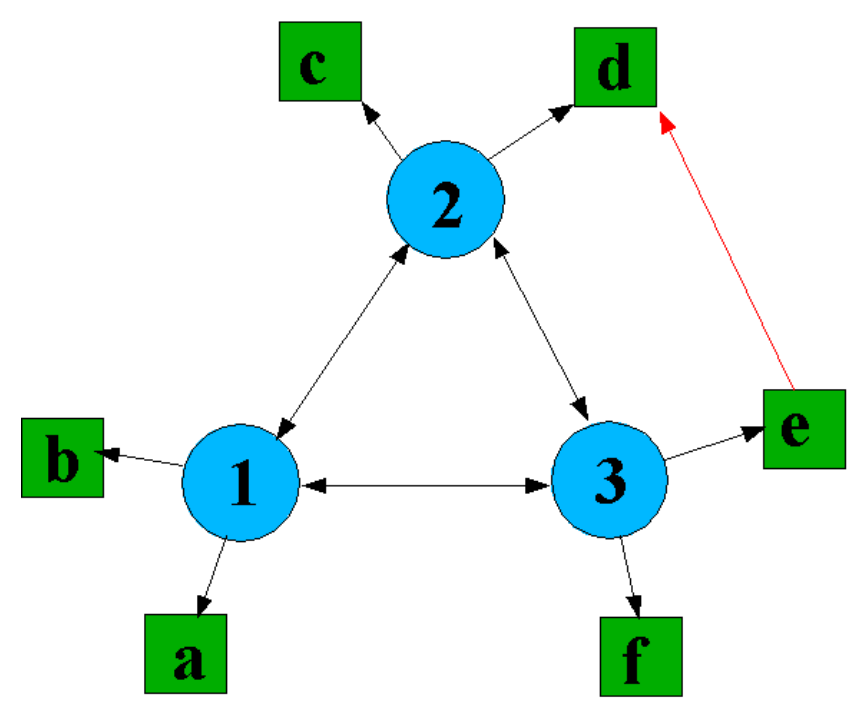

Figura 23: Diagrama geral da navegação nos conteúdos do sistema. Os círculos numerados em azul representam as áreas disponíveis (como Algarismos Significativos). As caixas nomeadas em verde representam os tópicos oferecidos pela área (como o tópico Sistema Tampão).

A partir dos esclarecimentos apresentados sobre o caráter modular do sistema, podese perceber que, com relação ao número de acessos ao tópico 1.0, para que o usuário acesse os 
sub-tópicos de 1.1 a 1.4 necessariamente, precisa acessar o tópico 1.0. O mesmo é válido para os tópicos 2.0 e 3.0. Assim, o grande número de acessos ao tópico 3.0, por exemplo, não permite que se conclua que foi o mais lido pelos estudantes, uma vez que em alguns momentos pode ter sido apenas utilizado como rota para acesso a um sub-tópico. É importante salientarmos a importância dada por alguns autores à forma como o conteúdo teórico de um sítio é organizado. Carpi ${ }^{29}$, que também construiu o sítio "The Natural Science Pages" de forma modular, credita parte de seu sucesso à estrutura por ele apresentada. Segundo o autor, este formato é um dos pontos positivos do sítio, uma vez que auxilia o usuário na localização de porções importantes do conteúdo de maneira fácil e eficiente e favorece a concentração em um determinado tópico ${ }^{29}$.

Uma organização diferenciada da organização modular foi dada aos conteúdos por Weaver $^{28}$. No sítio por ela construído os conteúdos são oferecidos aos alunos em um menu lateral, organizado seqüencialmente, chamado de página de atalho. Ou seja, links para todos os tópicos oferecidos podem ser acessados pelos estudantes a partir de qualquer página. Este trabalho se apresenta como um dos poucos em que o monitoramento do acesso dos estudantes às páginas de conteúdo é realizado. Neste caso a autora utiliza os arquivos de histórico (log) do sistema como forma de determinar o número total de acessos feitos a uma determinada página. A estratégia adotada pela autora permite apenas saber quantos acessos foram feitos a uma determinada página, mas não permite saber o trajeto realizado por cada um dos alunos. Em nosso caso, a ferramenta de monitoramento nos permite saber todo o trajeto realizado por um estudante. O monitoramento feito pela autora em seu trabalho permitiu a elaboração da Figura 24 que ilustra o número total de acessos a cada uma das páginas do sistema. 


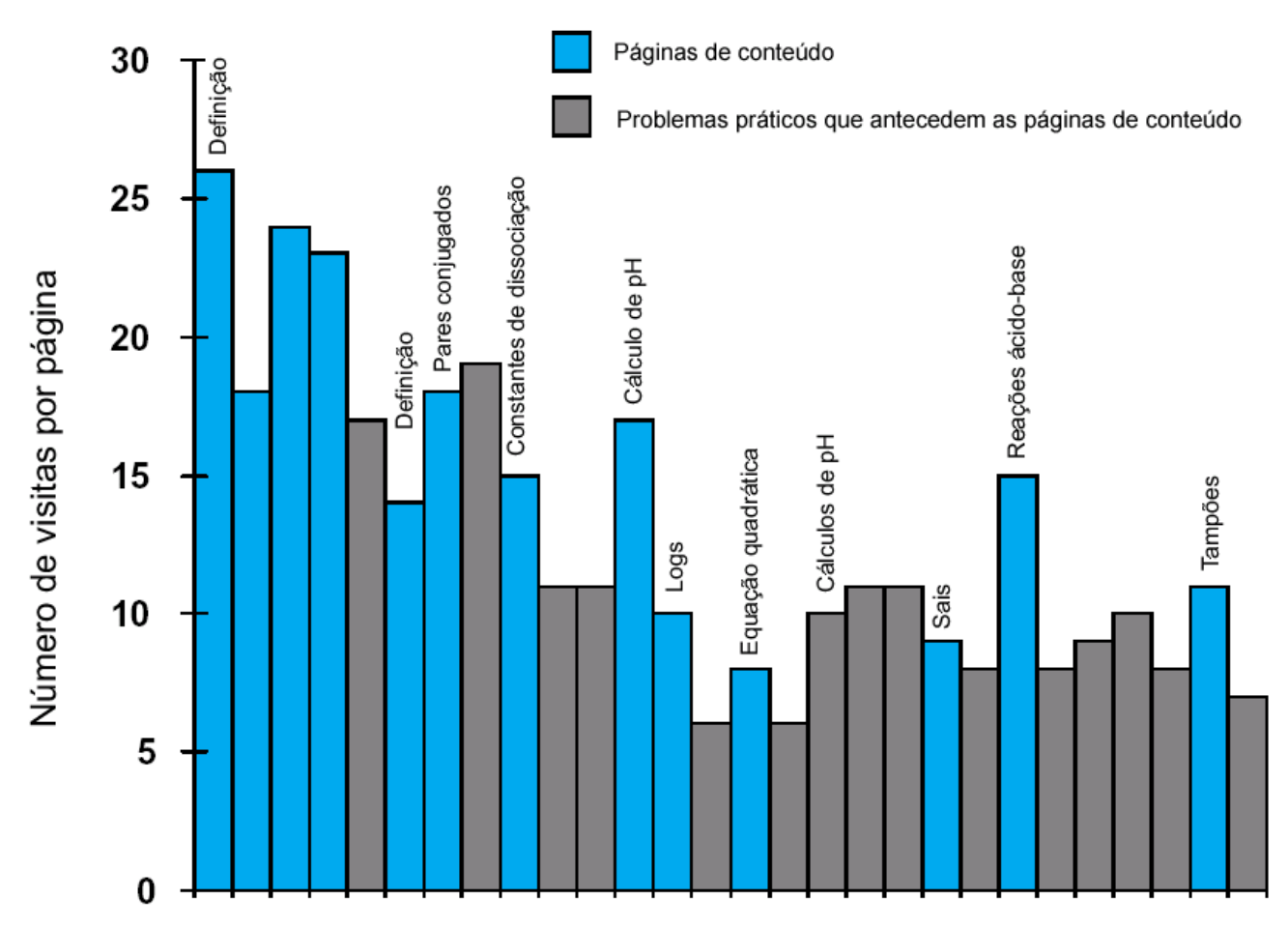

Figura 24: Gráfico do número de visitas totais para cada página do sítio construído por Weaver $^{28}$. As barras azuis representam páginas de conteúdo e as barras cinzas representam problemas práticos oferecidos no sistema.

A partir da análise da Figura 24, a autora conclui que os estudantes visitam as páginas disponíveis no sítio de forma predominantemente cronológica, ou seja, na mesma ordem em que os tópicos são abordados durante o semestre, caracterizando o estilo linear de navegação, e podem não ter tempo suficiente para terminar o estudo. Assim tópicos finais abordados na disciplina e localizados no fim da página de atalhos são menos visitados que os tópicos iniciais.

Levando em conta as considerações de $\mathrm{Weaver}^{28}$, acreditamos que, de uma maneira geral a análise da Figura 22 nos indica que, no caso do nosso sítio, os alunos fizeram uma navegação não linear. Ou seja, acessaram diretamente as páginas que julgaram necessárias para a resolução das suas dificuldades ao invés de percorrerem todos os tópicos disponíveis, antes de se dedicarem ao estudo de um deles. Esta afirmativa se baseia no maior número de acessos aos tópicos 2.0 e 3.0, quando comparados ao tópico 1.0 e do tópico 3.0, quando 
comparado ao 2.0. O aumento no número de acessos entre os tópicos 1.0, 2.0 e 3.0 mostra que a área de Análise Volumétrica foi a mais visitada e os acessos aos tópicos internos desta área não sugerem nenhuma ordem aparente, indicando a escolha dos alunos por determinados tópicos.

\subsection{A navegação individual dos alunos, dos professores e dos estagiários}

\subsubsection{A navegação individual dos alunos}

A ferramenta de monitoramento da navegação nos permitiu obter a ordem com que as páginas foram acessadas por todos os alunos cadastrados durante o semestre. Uma análise prévia dos dados de navegação nos mostrou dois padrões distintos na forma como os estudantes usaram o sítio. O primeiro padrão foi adotado por alunos que não navegaram nas páginas de Conteúdo restringindo sua navegação às páginas: Rosto, Envio de Relatório e Contato. O segundo foi adotado por alunos que navegaram tanto nas páginas acima citadas quanto nas páginas de conteúdo. Levando em conta a dificuldade de visualização que o leitor teria caso sintetizássemos as informações de navegação de todos os estudantes em um mesmo gráfico, optamos por apresentar a navegação de 2 alunos com o primeiro padrão de navegação no gráfico da Figura 25(A) e de 2 alunos com o segundo padrão de navegação no gráfico da Figura 25(B), sem levar em consideração data e hora de acesso ao sítio.

O eixo X representa os acessos ordenados de forma crescente e o eixo Y representa a página visitada. A origem do eixo $\mathrm{X}$ não representa página alguma; os pontos 1 a 4 representam respectivamente as páginas: Página de Rosto, Envio de Relatório, Glossário e Contato. Do ponto 5 ao ponto 40 são apresentadas as páginas de conteúdo na mesma ordem 
em que aparecem na Tabela 2. Os pontos 5 a 12 representam as páginas de Algarismos Significativos (tópicos 1.0 a 1.P.1), 13 a 24 representam as páginas de Análise Gravimétrica (tópicos 2.0 a 2.4) e de 25 a 40 as páginas de Análise Volumétrica (tópicos 3.0 a 3.P.7).
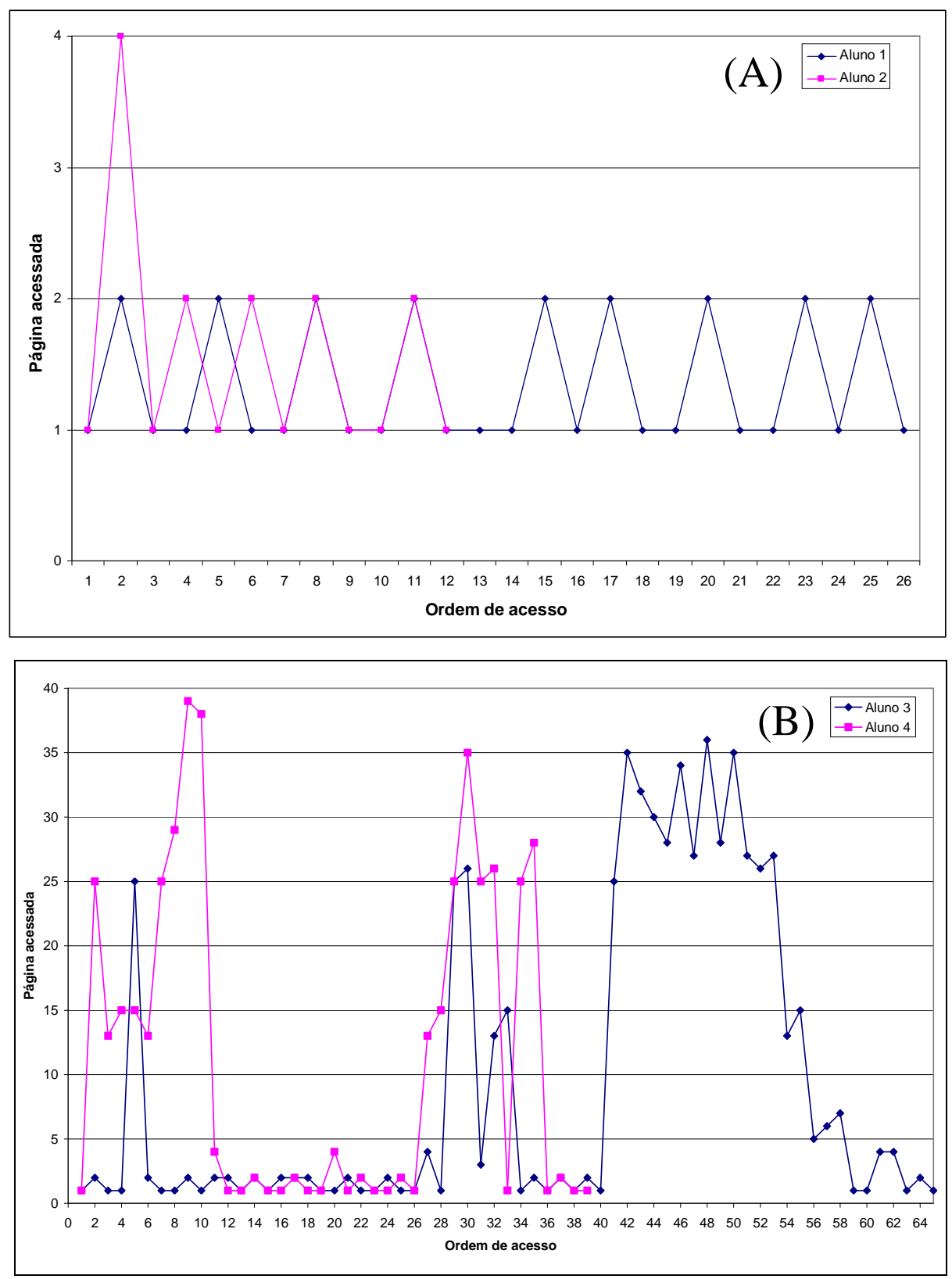

Figura 25: (A) Gráfico da navegação individual para dois alunos que navegam apenas nas páginas: Rosto, Envio de Relatório e Contato - padrão 1. (B) Gráfico da navegação individual para dois alunos que navegam nas páginas acima citadas, no Glossário e nas páginas de conteúdo - padrão 2. O eixo $\mathrm{Y}$ representa as páginas disponíveis no sistema. $\mathrm{O}$ eixo $\mathrm{X}$ representa a ordem de acesso pelo estudante. 
Verificamos que 15 alunos (46,9\%) adotaram o primeiro padrão de uso. Considerando apenas a ordem de navegação do aluno sem levar em conta data e hora de acesso, construímos então o gráfico da Figura 26 que expressa de maneira mais clara os pontos 1 a 4 . As linhas coloridas representam a ordem de navegação para cada um dos 15 alunos selecionados. Na realidade, menos de 15 linhas podem ser observadas na Figura 26 visto que a navegação é coincidente para vários alunos mascarando, desta forma, a navegação de alguns estudantes.

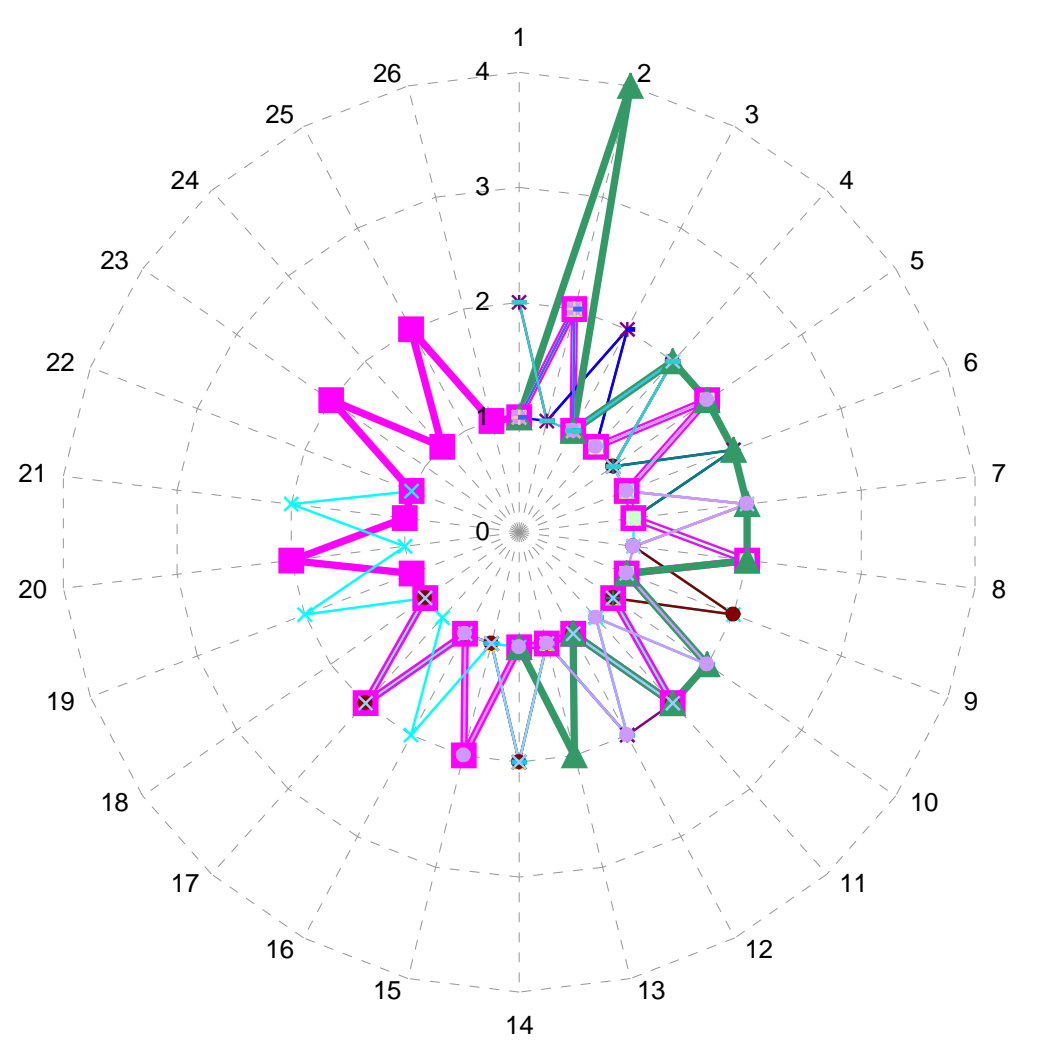

Figura 26: Gráfico de rede que exibe a navegação individual dos alunos para a página de Rosto, Envio de Relatório, Glossário e Contato, representadas pelos níveis de 1 a 4 , respectivamente. As linhas coloridas representam a navegação de cada aluno e iniciam no nível 1 (página de Rosto). Os números em volta do gráfico representam a ordem de acesso (com máximo em 26). Cada ponto representa um acesso à página em questão.

Com o intuito de esclarecer a maneira como a leitura do gráfico deve ser feita, destacamos a navegação de um aluno que adotou o primeiro padrão de navegação (visitando 26 páginas no total), que se encontra representada na Figura 26 em cor magenta e pontos 
quadrados. A leitura da navegação deste aluno pode ser feita da seguinte maneira: o acesso inicia-se na página de Rosto, seguido pelo acesso à página de Envio de Relatório e posterior redirecionamento à página de Rosto, após a interação. Podemos perceber também nos acessos 14 a 18 o envio de dois relatórios consecutivos uma vez que a página de Rosto é representada apenas uma vez no acesso 15 , mostrando que o aluno foi redirecionado à Página de Rosto e retornou à Página de Envio de Relatório no acesso 16.

A navegação de um segundo aluno, representada na Figura 26 pela cor verde com pontos triangulares, indica que após acesso à página de Rosto, ele utilizou o formulário de Contato, sendo enviado após a interação, novamente à página de Rosto e então seguiu ao Envio de Relatório. O gráfico indica que o aluno teve problemas na utilização da página de Envio de Relatórios, visto que nos acessos 4 a 8 e 10 a 11, o aluno permaneceu na mesma página, ou seja, o fato do aluno não ter sido redirecionado à Página de Rosto mostra a ocorrência de algum problema com a utilização da página, que pode ser justificada por alguma informação incorreta adicionada ao formulário ou por problemas de lentidão na rede.

Conforme pode ser observado na Figura 26, a navegação dos estudantes, com o intuito de enviar um relatório, circunda apenas as duas páginas supracitadas (página de Rosto e Envio de Relatório) e de maneira ordenada, oscilando entre a página 1 e 2, que sugere uma intenção específica de uso de 15 estudantes a praticamente apenas esta funcionalidade do sítio. Interessante observarmos também que para este padrão de navegação, apenas um acesso foi verificado à página de Contato e nenhum acesso foi verificado para o Glossário. Com relação à página de Contato esperávamos que os estudantes contatassem o administrador a fim de sanar alguma dúvida quanto à utilização das ferramentas, fato que não aconteceu. Com relação ao Glossário o fato já era esperado considerando que dúvidas a respeito da 
terminologia só poderiam surgir com a leitura do conteúdo teórico que não foi acessado pelos alunos com este padrão de navegação.

A análise dos dados obtidos também nos permite dizer que 17 alunos $(53,1 \%)$ adotaram o segundo padrão de navegação. O aluno que fez o menor número de acessos neste padrão de navegação percorreu 4 páginas, enquanto que o aluno que fez o maior número de acessos percorreu 65 páginas e encontra-se representado na Figura 25(B) pela cor azul (Aluno 3). Com exceção dos acessos 5 e 6 feitos aos tópicos 3.0 e 3.5.3 respectivamente, o aluno se limitou até o acesso 29 a usar apenas as quatro primeiras páginas do sistema com pouco comportamento exploratório e nos acessos restantes assumiu comportamento exploratório, acessando diversas páginas do conteúdo oferecido. Já para um segundo aluno (Aluno 4), com este padrão de navegação, percebemos um comportamento exploratório claro visto que o aluno inicia sua navegação na página de Rosto, acessa os tópicos 3.0 e 3.4.2, vai aos tópicos 2.0 e 2.2, retornando aos tópicos 3.0, 3.4.2, 3.P.6 e 3.P.7. Dos acessos 12 ao 27 o aluno se limita a utilizar as páginas 1 a 4, citadas anteriormente, e então volta a explorar o sítio acessando páginas das áreas de Análise Gravimétrica e Volumétrica de maneira não linear. O aluno ainda finaliza a navegação no semestre enviando um relatório no acesso 40.

Nossa análise permite afirmar ainda que, caso os estudantes navegassem de forma linear no conteúdo, como sugere Weaver $^{28}$ esperaríamos uma reta crescente iniciando no nível 5 do gráfico (que corresponde ao tópico 1.0). A análise individual da navegação dos alunos mostra que os estudantes não navegam de maneira linear, fato que pode ser justificado pelo caráter modular do conteúdo teórico que permite ao aluno escolher um tópico de interesse e prosseguir nele ${ }^{29}$. 
Analisando as áreas acessadas por cada aluno em sua navegação individual, construímos a Tabela 5 que correlaciona o número de estudantes que acessou cada uma das áreas oferecidas pelo sistema.

Tabela 5: Tipo de acesso às áreas de conteúdo e o número total de alunos que exibiram este comportamento.

\begin{tabular}{c|c}
\hline Acesso às áreas & Número de alunos \\
\hline 1 & 2 \\
\hline 2 & 2 \\
\hline 3 & 3 \\
\hline 1 e 2 & 1 \\
\hline 1 e 3 & 3 \\
\hline 2 e 3 & 4 \\
\hline 1,2 e 3 & 2 \\
\hline
\end{tabular}

Os números exibidos na Tabela 5 nos sugerem que a quantidade de conteúdo teórico oferecida influi diretamente no número de acessos, visto que se compararmos os acessos para os pares de áreas "1 e 2", "1 e 3" e "2 e 3", veremos que o número de estudantes que acessam estas áreas aumenta conforme aumenta o conteúdo disponível. Os números sugerem ainda a consolidação do sítio com o tempo de uso pelos estudantes: se considerarmos que 8 alunos acessam a área 1 (Algarismos Significativos), 9 alunos acessam a área 2 (Análise Gravimétrica) e 12 alunos acessam a área 3 (Análise Volumétrica), percebemos o aumento no número de estudantes que se utilizam da ferramenta no decorrer do semestre. Os gráficos de navegação para cada aluno são reproduzidos no Anexo F.

Analisando ainda as datas de acesso dos alunos ao material, construímos o gráfico representado na Figura 27 que relaciona o número total de acessos a cada mês de aplicação do sítio. Percebemos que o tráfego máximo ocorrido no sítio se deu no mês de Novembro com 290 acessos. Percebemos também o incremento no uso do sítio ocorrido entre os meses de Setembro a Novembro de 2004 confirmando nossa especulação sobre a consolidação do sítio com o decorrer do semestre. O decréscimo observado no número de acessos no mês de 
Dezembro pode ser justificado pelo fim do semestre letivo e 3 acessos são observados no mês de Janeiro de 2005 provavelmente para a entrega de relatórios da prática de reposição.

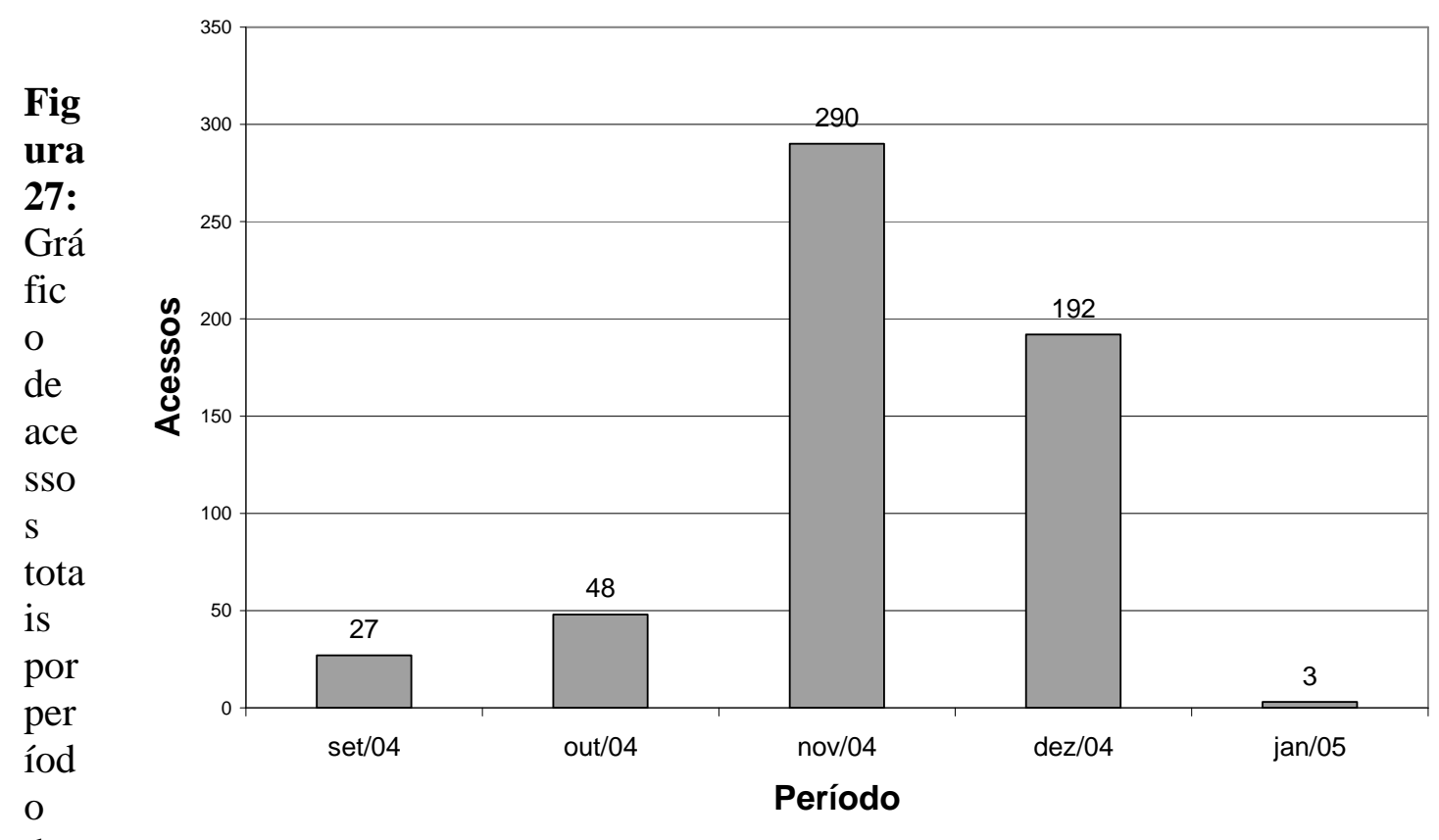

de

tempo. O eixo das abscissas exibe intervalos mensais de tempo e a ordenada exibe o número absoluto de acessos.

Cabe também dizer que dos 560 acessos realizados pelos estudantes $58 \%$ aconteceram de 08:00 às 18:00 horas e 42\% das 18:01 às 17:59 horas, o que nos sugere que não existem diferenças significativas no horário de acesso.

\subsubsection{A navegação individual dos professores e estagiários}

Um gráfico de navegação individual do professor da Turma 1 e do estagiário da Turma 2 foi também construído e encontra-se representado na Figura 28. Não foram observados acessos que pudessem ser monitorados durante o semestre por parte do professor da Turma 2 e os nossos acessos, como estagiário da Turma 1 não foram considerados visto que acessamos o sítio durante o semestre com intenções de testar e verificar sua programação, 
tornando impossível determinar os acessos que realizamos como estagiário ou como administrador do sítio.

O gráfico da Figura 28 representa a navegação do estagiário da Turma 2 e do professor da Turma 1. A ordem dos acessos é independente do tempo.

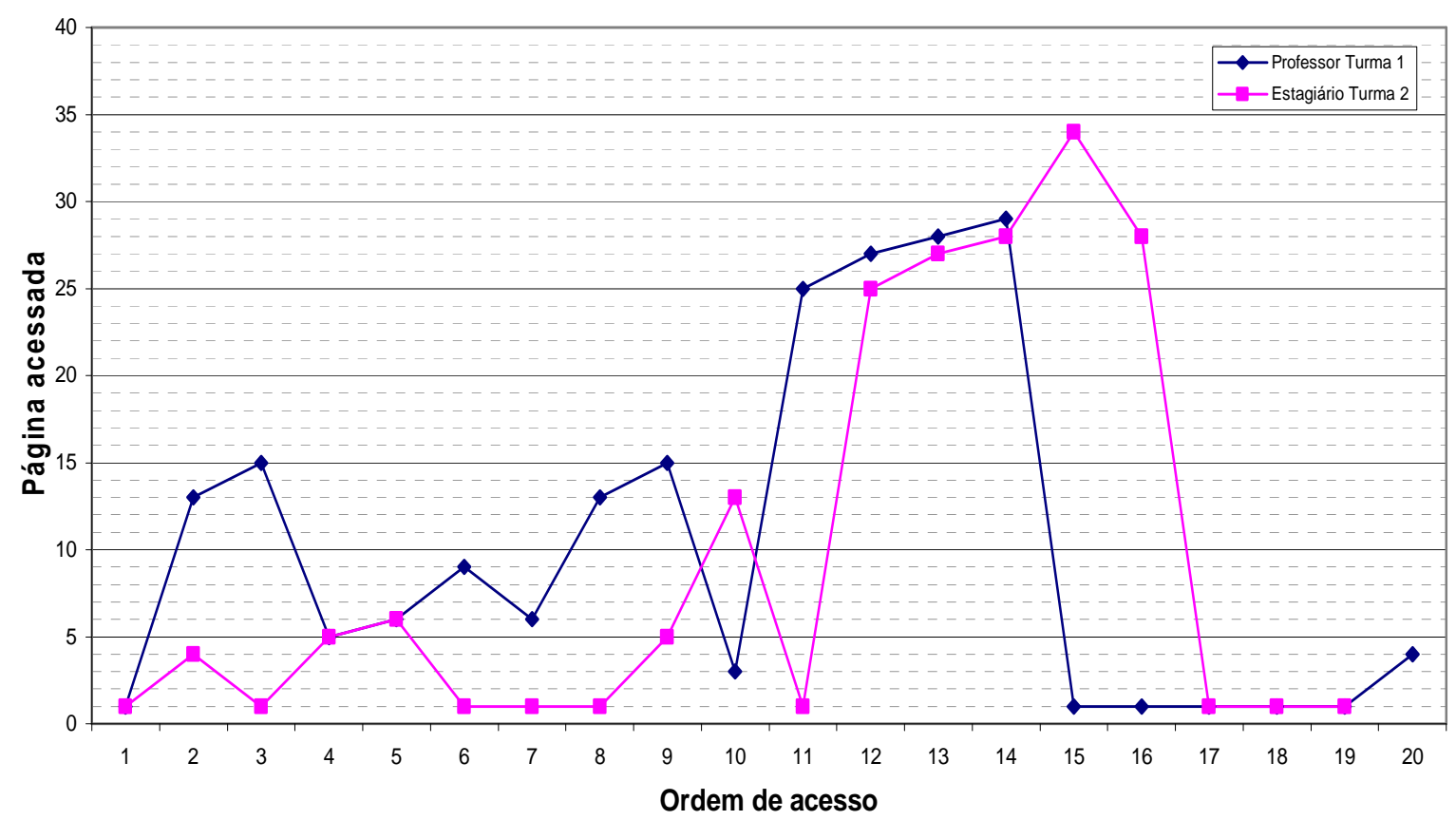

Figura 28: Gráfico da navegação individual do professor da Turma 1 e estagiário da Turma 2. A barra azul representa a navegação do professor da Turma 1 e a barra magenta a navegação do estagiário da Turma 2. Os pontos coloridos representam cada página acessada. $\mathrm{O}$ eixo Y representa as páginas disponíveis no sistema. $\mathrm{O}$ eixo $\mathrm{X}$ representa a ordem de acesso pelo professor/estagiário.

Conseguimos detectar 20 acessos por parte do professor da Turma 1 e 19 acessos por parte do estagiário da Turma 2. Com relação aos acessos realizados pelo professor da Turma 1, podemos sugerir que se deram com o intuito de explorar o material disponível no sítio, visto que o professor acessa páginas da área 2 (Análise Gravimétrica), indicadas no gráfico entre os acessos 2 e 3, volta à área 1 (Algarismos Significativos) com as páginas indicadas no gráfico entre os pontos 4 a 7, percorrendo-a de maneira quase linear, vai ao Glossário, indicado na Figura 28 pelo acesso 10, e depois acessa a área 3 (Análise 
Volumétrica) correspondentes aos acessos 11 a 14. Realiza este último percurso de maneira quase linear, visto que os acessos na área 3 geram uma reta crescente. Os acessos finais sugerem que a intenção de acesso do professor era a de verificar algum recado ou notícia pelo sítio, visto que a página de Rosto é acessada 5 vezes. O último acesso foi à página de Contato com o administrador. Vale lembrar que apenas acessos às páginas do módulo Aluno foram monitoradas, assim sendo, os acessos feitos pelos professores e estagiários às páginas Adicionar Conteúdo, Adicionar Recado e Verificar Relatórios não puderam ser analisados.

Com relação à navegação do estagiário da Turma 2 sugerimos que tenha ocorrido visando principalmente a exploração do material disponível no sítio. O estagiário iniciou sua navegação na página de Rosto e seguiu à página de Contato. Após ser reenviado à página de Rosto, o estagiário acessa a área 1 (acessos 4 e 5) e volta à página de Rosto nos acessos 6 a 8. O estagiário visita novamente a área 1 e segue à área 2. Após acesso ao tópico 2.0 o estagiário volta à pagina de Rosto e então acessa o tópico 3.0. A partir daí acessa alguns sub-tópicos da mesma área, voltando à página de Rosto. Esta navegação sugere que o estagiário provavelmente navegava apenas de forma a determinar o conteúdo disponível, e não a fim de realizar uma pesquisa ou leitura do material. Os últimos acessos do estagiário (17 a 19) se referem à página de Rosto indicando, como no caso do professor da Turma 1, a intenção de verificar algum recado ou notícia pelo sítio.

Com o intuito de confirmarmos nossas suspeitas com relação aos objetivos da navegação do professor da Turma 1 e estagiário da Turma 2 e também de conhecermos a opinião dos mesmos sobre o uso de computadores e da Internet no ensino de química e sobre o sítio por nós elaborado, realizamos com cada um deles, e também com o professor da Turma 2, uma entrevista semi-estruturada composta pelas seguintes perguntas: 
1. Você já havia utilizado anteriormente a Internet como ferramenta de apoio ao processo de ensino e aprendizagem em disciplinas do curso de química?

2. Como você encara o uso de computadores e da Internet no processo de ensino e aprendizagem de química?

3. Quais foram as razões que levaram você a navegar no sítio por nós elaborado? E em quais páginas você navegou?

4. Qual a sua opinião sobre o sítio por nós elaborado e sobre o processo de aplicação do mesmo na disciplina de Laboratório de Química Analítica? Você poderia fazer sugestões para o aprimoramento no que diz respeito ao sítio e ao processo de aplicação? Quais?

As respostas apresentadas pelos professores indicaram que nenhum deles havia utilizado anteriormente a Internet como ferramenta de apoio ao ensino de química. No entanto, ambos se manifestaram positivamente com relação ao emprego de tais recursos, sendo esta opinião também compartilhada pelo estagiário da Turma 2.

No que diz respeito à navegação do professor da Turma 1, este afirmou não ter realizado uma navegação muito extensa, tendo acessado o sítio inicialmente por curiosidade, com o intuito de saber como estava montado e o que estava presente em termos de conteúdo, e também para verificar os relatórios enviados pelos alunos. Tais colocações corroboram a nossa percepção, mencionada anteriormente, a respeito dos objetivos da sua navegação. $\mathrm{O}$ professor da Turma 2 também afirmou ter acessado o sítio por curiosidade, tendo navegado em páginas que não possuíam a ferramenta de monitoramento.

O estagiário da Turma 2 afirmou ter acessado o sítio regularmente com os seguintes objetivos: participação em plantões de dúvida; verificação de mensagens enviadas pelos alunos; observação do conteúdo didático. Ou seja, assim como verificado para o professor da Turma 1, as colocações do estagiário da Turma 2 corroboram a nossa percepção, mencionada anteriormente, a respeito dos objetivos da sua navegação.

As opiniões dos professores e do estagiário da Turma 2 sobre o sítio são positivas e as sugestões de aprimoramento por eles apresentadas dizem respeito mais estreitamente ao 
processo de aplicação da proposta do que à organização do sítio e ao conteúdo nele presente. Nesta perspectiva, o estagiário da Turma 2 sugeriu que fosse oferecido aos alunos, no início do semestre, um treinamento para utilização do sítio e também sugeriu que fossem colocados em prática mecanismos capazes de favorecer uma participação mais efetiva dos alunos no plantão de dúvidas (monitoria). O estagiário sugeriu também o incentivo do uso do sítio pelos professores, de tal forma que os alunos sejam conseqüentemente influenciados a usar a aplicação. Como sugestões para o aprimoramento do sítio, o professor da Turma 1 lembrou da limitação da ferramenta de Envio de Relatório no que diz respeito ao envio de imagens ou gráficos quando da construção de um relatório, e afirmou ser bastante positiva a implementação desta funcionalidade na ferramenta.

\subsection{O fórum de discussão}

Conforme mencionamos anteriormente, os alunos podiam utilizar o sítio para entrar em contato com o administrador, via e-mail, ou exporem suas dúvidas através do fórum de discussão. A tela inicial deste aplicativo encontra-se ilustrada na Figura 29. O fórum foi dividido em salas associadas a cada uma das práticas. 


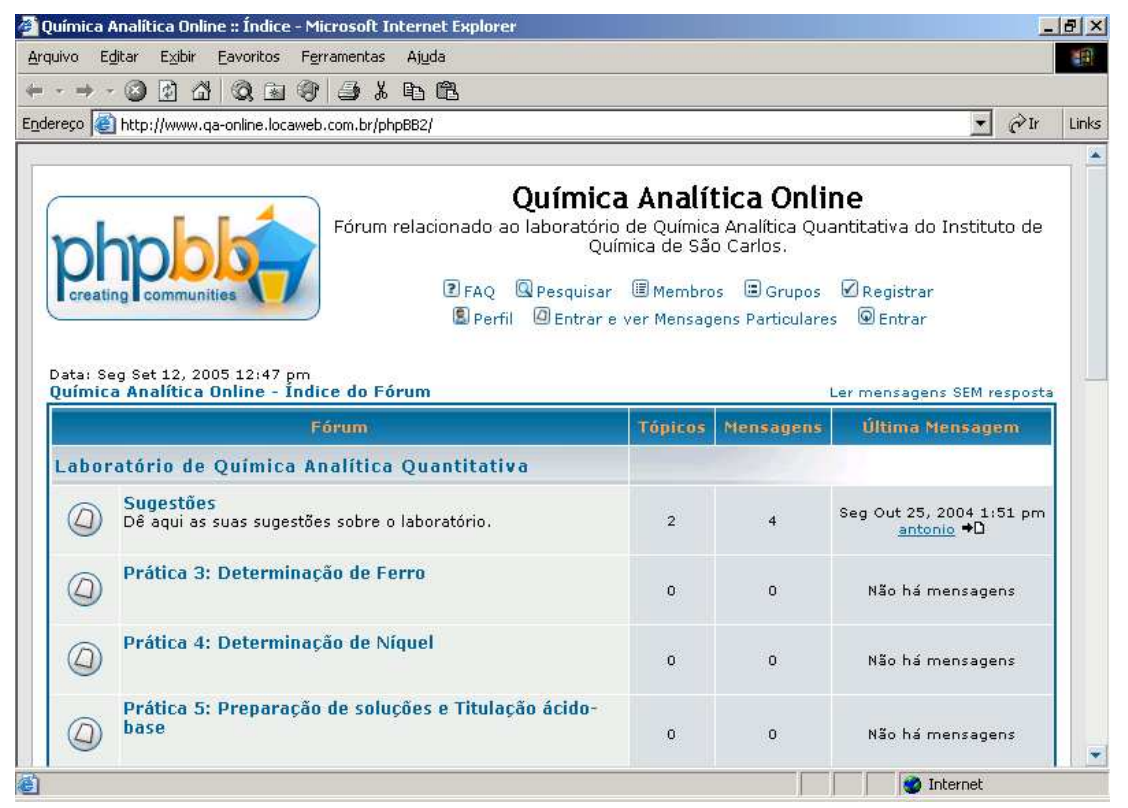

Figura 29: Página inicial do fórum de discussão PHPBB2.

Foram abertas 11 salas, sendo 9 referentes às práticas (a partir da terceira prática), uma sala de sugestões e uma de dúvidas gerais. Ao fim do semestre 4 alunos haviam utilizado o fórum e 17 mensagens haviam sido enviadas. Apenas 3 salas foram utilizadas: Sugestões, Dúvidas Gerais e Prática 11 - Volumetria de Complexação - EDTA. Cabe ressaltar que das 17 mensagens, 9 são respostas do administrador às questões dos alunos, 5 são questionamentos de um mesmo aluno e os outros 3 alunos são responsáveis cada um por uma mensagem, totalizando as 17 mensagens armazenadas no fórum. Verificamos que apesar do número pequeno de alunos que se propôs a usar o fórum, 12,5\% dos alunos cadastrados no sítio, este se apresentou como uma ferramenta de contato mais eficiente que o e-mail considerando-se que as dúvidas e sugestões, enviadas e respondidas, estão agora a disposição de qualquer pessoa que porventura venha a se cadastrar no fórum. Assim, esta ferramenta assume o papel de um repositório de questões que pode ser consultado por alunos de turmas posteriores como afirmam Paulisse e Polik ${ }^{40}$. 
O maior número de mensagens recebidas via fórum, em comparação ao número recebido via e-mail, pode ser devido ao fato do fórum permitir que o aluno resguarde sua identidade, uma vez que, por se tratar de uma aplicação externa ao sítio, o uso do fórum estava condicionado a um novo cadastro por parte do estudante, preservando seu anonimato. De fato, Paulisse e Polik ${ }^{40}$ afirmam que os estudantes se sentem mais confortáveis quando comentários são postados de forma anônima.

A seguir são reproduzidas e comentadas as sugestões apresentadas no fórum pelos alunos, assim como as dúvidas gerais e as dúvidas relacionadas à Prática 11. As sugestões apresentadas no fórum pelos alunos encontram-se no Quadro 32.

\begin{tabular}{|c|c|c|}
\hline & SUGESTÃO 1 & SUGESTÃO 2 \\
\hline Visitante & $\begin{array}{l}\text { Enviada: Sáb Out } 23,20048: 13 \text { pm } \\
\text { Assunto: meu relatório } \\
\text { perdido!!!!!!!!!!!!!!!!!!!!!!!!!!!!!!!!!!!!! } \\
\text { levei um dia inteiro fazendo o relatório e não } \\
\text { sei se ele foi enviado corretamente, acho q } \\
\text { deveriamos receber um aviso ou coisa do } \\
\text { tipo!!!!!!!!!! }\end{array}$ & $\begin{array}{l}\text { Enviada: Sáb Out 23, } 2004 \text { 8:20 pm } \\
\text { Assunto: Relatórios } \\
\text { Depois de passar um dia todo digitando um } \\
\text { relatório, ele simplesmente desaparece e não } \\
\text { sabemos se foi enviado ou não. Sendo assim. } \\
\text { acho melhor continuar entregando relatórios } \\
\text { impressos. Pelo menos é mais seguro!!! }\end{array}$ \\
\hline & $\begin{array}{l}\text { Enviada: Seg Out 25, } 2004 \text { 1:51 pm } \\
\text { Assunto: jah estou providenciando. } \\
\text { A confirmação vai entrar no ar antes da } \\
\text { proxima aula. ok? }\end{array}$ & $\begin{array}{l}\text { Enviada: Seg Out 25, } 2004 \text { 1:50 pm } \\
\text { Assunto: eles nao desaparecem } \\
\text { o seu relatorio foi enviado com sucesso se vc } \\
\text { for redirecionada para a pagina inicial. (isso } \\
\text { estah escrito na borda branca da pagina de } \\
\text { envio de relatorio). } \\
\begin{array}{l}\text { Jah estou programando uma confirmação apos } \\
\text { origado pela sugestao. }\end{array}\end{array}$ \\
\hline
\end{tabular}

Quadro 32: Mensagens enviadas à sala Sugestões do fórum de discussão.

As duas sugestões estão relacionadas à inquietação dos alunos, já mencionada anteriormente, no que diz respeito à necessidade de recebimento de confirmação do envio de relatório. Esta inquietação também foi observada em aulas nas quais os alunos abordaram os 
estagiários e sugeriram a necessidade de uma confirmação de que a entrega do documento havia acontecido com sucesso.

As dúvidas gerais apresentadas no fórum pelos alunos encontram-se apresentadas no Quadro 33.

\begin{tabular}{|c|c|c|}
\hline & DÚVIDA 1 & DÚVIDA 2 \\
\hline Visitante & $\begin{array}{l}\text { Enviada: Seg Dez 06, } 2004 \text { 10:19 pm } \\
\text { Assunto: Respostas no fórum!!! } \\
\text { Olá!!! eu faço pra responder a alguma msg } \\
\text { Como eu postada no forum??? } \\
\text { jah no realme naum tenho intimidade com } \\
\text { Eu realmente por isso!!!hhehe } \\
\text { foruns... } \\
\text { Inteh } \\
\text { Valeu!! }\end{array}$ & $\begin{array}{l}\text { Enviada: Qui Dez 02, } 200411: 00 \mathrm{pm} \\
\text { Assunto: Meu relatório fica todo desconfigurado } \\
\text { Quando envio meu relatório, eu usualmente } \\
\text { digito no word e colo no site. Porém quando eu } \\
\text { colo ele desconfigura as margens, tabulação } \\
\text { entre outras coisas... quando vcs recebem o } \\
\text { relatório, ele continua desconfigurado??? Eu } \\
\text { prefiro mandar impresso do que pelo site pois } \\
\text { eu sei que ele fica arrumado!!! posso mandar } \\
\text { sem mesmo??? } \\
\text { Obrigado!!! problemas }\end{array}$ \\
\hline Site Admin & $\begin{array}{l}\text { Enviada: Dom Dez 19, } 20042: 25 \mathrm{pm} \\
\text { Assunto: basta clicar no botaozinho chamado } \\
\text { POST REPLY. } \\
\text { Se vc estiver cadastrado, precisa apenas } \\
\text { clicar neste botao e escrever sua mensagem, } \\
\text { o sistema preenche os seus dados, ok? } \\
\text { Falow! }\end{array}$ & $\begin{array}{l}\text { Enviada: Sex Dez 03, } 2004 \text { 7:45 pm } \\
\text { Assunto: Pode sim. } \\
\text { Isto acontece porque a largura da coluna do } \\
\text { site é menor que a largura de uma página do } \\
\text { word. Mesmo que na inserção, a página } \\
\text { desconfigure, na verificação nós podemos } \\
\text { aumentar esta largura, assim o relatório não } \\
\text { está realmente desconfigurado, apenas não é } \\
\text { exibido da forma como foi digitado. } \\
\text { Podem enviar sem problemas. }\end{array}$ \\
\hline
\end{tabular}

Quadro 33: Mensagens enviadas à sala Dúvidas Gerais do fórum de discussão.

As dúvidas apresentadas no Quadro 33 estão relacionadas com dificuldades dos alunos na compreensão de algumas funcionalidades do sítio. Desta forma, apontam para a necessidade do oferecimento de maiores esclarecimentos a respeito das possibilidades dos alunos antes que iniciem a navegação. Olivier e colaboradores ${ }^{79}$ recomendam que iniciativas como treinamentos e tutoriais sejam oferecidos aos estudantes mesmo sendo o uso da Internet 
praticamente universal entre alunos do ensino superior de química nos EUA. Os poucos alunos que se depararam com dificuldades neste uso devem ser atendidos.

Conforme mencionamos anteriormente, todos os alunos que nos procuraram para solucionar dúvidas com relação ao funcionamento do sítio foram atendidos. No entanto, a partir das colocações apresentadas no fórum e do conhecimento que temos atualmente sobre experiências relatadas na literatura, constatamos que uma apresentação formal do sítio - seja em forma de tutorial, seja colocando à disposição dos alunos uma apostila sobre o seu funcionamento - pode ser útil para evitar que dúvidas, como as apresentadas no Quadro 33, se concretizem.

Com relação à segunda dúvida apresentada no Quadro 33, a mensagem postada mostra a preocupação do aluno em entregar relatórios corretamente formatados. Esta observação respalda as percepções de Paulisse e Polik ${ }^{40}$, que destacam a importância da existência de ferramentas na Internet que viabilizem a comunicação das idéias a respeito de tópicos da química, respeitando as características inerentes desta disciplina.

As outras 2 dúvidas postadas pelos alunos diziam respeito à solicitação de esclarecimentos sobre questões relacionadas a tópicos estudados na disciplina (conteúdo teórico, cálculos, etc). Desta forma, o fórum se mostrou eficiente como mais um canal de comunicação, capaz de facilitar o processo de ensino e aprendizagem dos conteúdos ministrados na disciplina. As duas dúvidas colocadas pelos alunos encontram-se apresentadas no Quadro 34. 


\begin{tabular}{|c|c|c|}
\hline & DÚVIDA 3 & DÚVIDA 4 \\
\hline Visitante & $\begin{array}{l}\text { Enviada: Sáb Out 16, } 2004 \text { 12:49 am } \\
\text { Assunto: como determino a percentagem de } \\
\text { HAc em vinagre??? } \\
\text { Eu gostaria de saber como determino a } \\
\text { percentagem de HAc no vinagre. } \\
\text { eu tenho a concetração da solução diluída e } \\
\text { daí em diante estou meio perdido.... alguém } \\
\text { pode ajudar??? }\end{array}$ & $\begin{array}{l}\text { Enviada: Sex Out 15, } 2004 \text { 10:43 pm } \\
\text { Assunto: como determino a normalidade ?? } \\
\text { Gostaria de saber como resolvo os calculos da } \\
\text { pratica ...qdo pede se a normalidade ......é a } \\
\text { mesma que o teor? }\end{array}$ \\
\hline 0 & 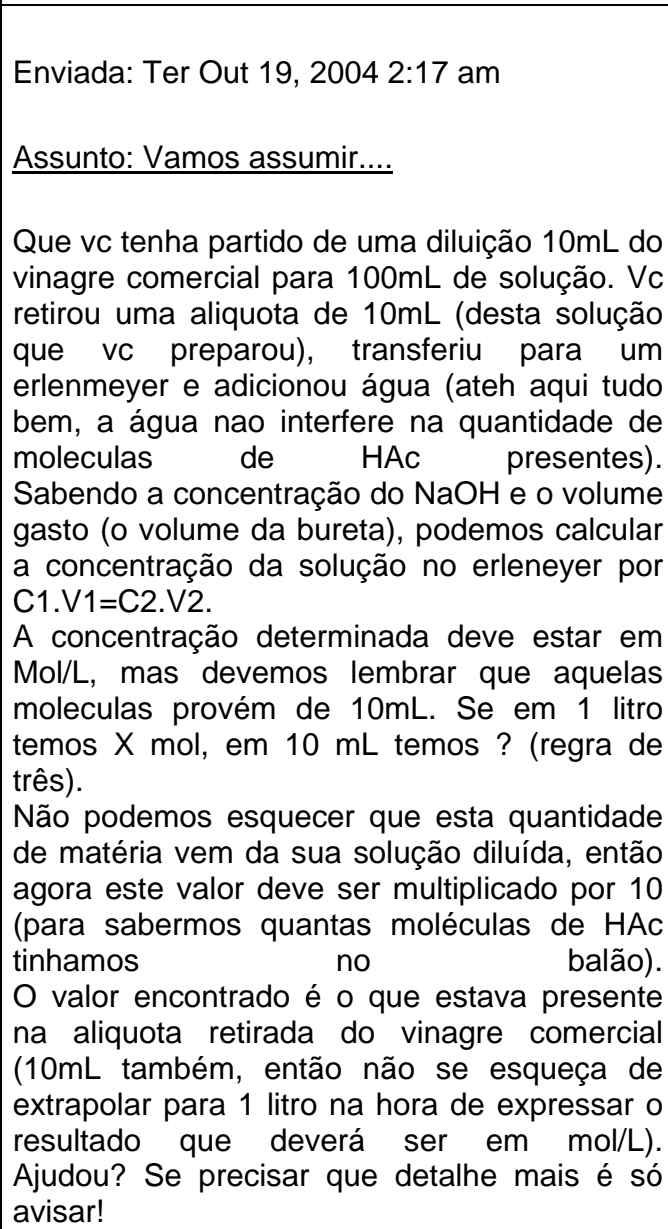 & 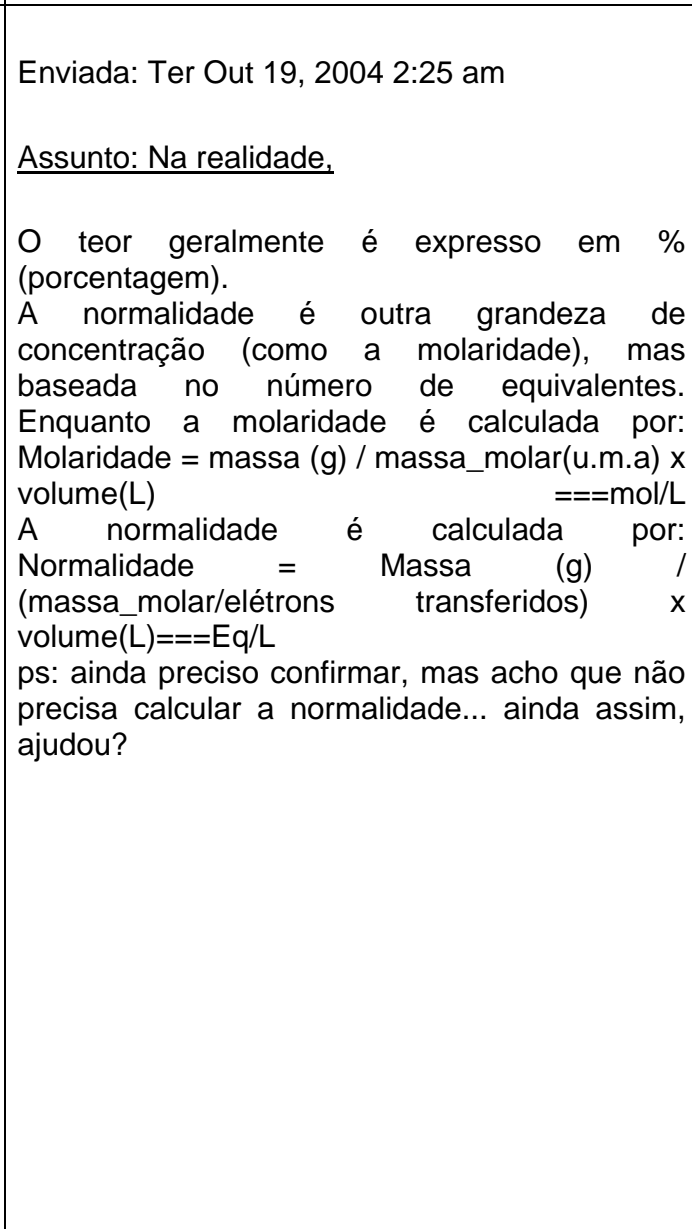 \\
\hline
\end{tabular}

Quadro 34: Mensagens enviadas à sala Dúvidas Gerais do fórum de discussão.

Com relação as salas do fórum destinadas às práticas realizadas no laboratório, apenas uma foi utilizada: a que tratava da Prática 11, sobre Volumetria de Complexação EDTA. Vale lembrar aqui a existência de uma dúvida (dúvida 3) relacionada à determinação da concentração de ácido acético em vinagre enviada à sala de Dúvidas Gerais. Na realidade esta pergunta deveria ter sido enviada à sala da Prática 6, sobre Acidimetria. Acreditamos que 
as outras salas não tenham sido utilizadas em parte por dois motivos: a adaptação à ferramenta, pois o primeiro questionamento enviado ao fórum data de 15/10, período em que os estudantes estavam executando a prática 6, sobre Titulação Ácido-base - Acidimetria. O segundo motivo seria a maior complexidade dos cálculos relacionados às práticas 6 e 11 , determinação de ácido acético em vinagre e determinação da concentração de cálcio e magnésio respectivamente. É sabido que todas as vezes que a disciplina é oferecida, alguns alunos mostram problemas na realização destes cálculos. Foram enviados dois questionamentos sobre o assunto, que se encontram apresentados no Quadro 35.

\begin{tabular}{|c|c|c|}
\hline & DÚVIDA 5 & DÚVIDA 6 \\
\hline Visitante & $\begin{array}{l}\text { Enviada: Seg Dez 06, } 2004 \text { 10:15 pm } \\
\text { Assunto: Como eu calculo o teor de calcio e } \\
\text { magnesio??? } \\
\text { Na parte da determinação da concetração de } \\
\text { Ca2+ e Mg2+ em uma amostra, também é } \\
\text { pedido o teor dos cátions. Como eu faço } \\
\text { isso??? É pela concentração em gramas por } \\
\text { litro dividido por } 10 \text { ou é de outra forma??? } \\
\text { Inteh!!! } \\
\text { Obrigado }\end{array}$ & $\begin{array}{l}\text { Enviada: Qui Dez 02, } 2004 \text { 11:05 pm } \\
\text { Assunto: Existe conteúdo teórico para } \\
\text { Volumetria de EDTA e REDOX??? } \\
\text { Eu andei olhando pelo site e não encontrei } \\
\text { conteúdo teórico sobre volumetria de EDTA e } \\
\text { REDOX. Não tem mesmo ou ainda não foi } \\
\text { adicionado ao site??? é interessante pois quem } \\
\text { faz analítica II teórica tem prova dia } 10 \text { e é mais } \\
\text { um lugar pra procurar a matéria.... } \\
\text { Ateh mais } \\
\text { Obrigado!!!! }\end{array}$ \\
\hline & $\begin{array}{l}\text { Enviada: Dom Dez 19, } 2004 \text { 2:30 pm } \\
\text { Assunto: Considerando } \\
\text { Considerando a densidade da água como } \\
\text { sendo } 1 \mathrm{~g} / \mathrm{mL} \text {, pode estimar o teor pela relação } \\
\text { entre a massa da espécie de interesse (cálcio } \\
\text { ou magnésio) e a massa de solução. a massa } \\
\text { de solução equivale a } 100 \% \text {, e a massa de } \\
\text { cálcio dentro dessa massa de solução? } \\
\begin{array}{ll}\text { Equivale } & \text { a } \% \text {. } \\
\text { Valeu? } & \end{array}\end{array}$ & $\begin{array}{l}\text { Enviada: Sex Dez 03, } 2004 \text { 7:41 pm } \\
\text { Assunto: este fim de semana } \\
\text { Olá. O conteúdo já foi selecionado. Vou fazer } \\
\text { de tudo pra coloca-lo no ar esta semana, ok? } \\
\text { Falow! }\end{array}$ \\
\hline
\end{tabular}

Quadro 35: Mensagens enviadas à sala da Prática 11, sobre Volumetria de Complexação EDTA, do fórum de discussão.

O primeiro questionamento diz respeito ao conteúdo teórico ministrado na disciplina e corrobora o fato, anteriormente mencionado, sobre o incremento oferecido pelo sítio na 
comunicação entre professores, estagiários e alunos. No segundo questionamento o estudante afirma não ter encontrado informações sobre um determinado assunto e complementa que tais informações seriam importantes no estudo de conteúdos também presentes em outras disciplinas. Desta forma, verificamos a existência de uma tendência, expressa pelo aluno em questão, de utilizar o sítio não apenas para sanar dúvidas da disciplina para a qual ele foi construído.

No que diz respeito aos horários em que as perguntas foram postadas no fórum, podemos afirmar observando data e hora de envio nos quadros anteriores que todas as mensagens foram postadas depois das 18:00h, horário em que professores e estagiários não costumam estar acessíveis. Esta constatação corrobora a tendência apontada por Paulisse e Polik $^{40}$ sobre a preferência dos alunos por interações humanas, sendo o estabelecimento da comunicação eletrônica, verificado principalmente, quando a primeira é dificultada.

\subsection{Os links externos adicionados ao sítio}

Links externos ao sítio foram também adicionados com o intuito de complementar alguns dos tópicos abordados. Os links foram inseridos na base de dados no mesmo momento da inserção do conteúdo relacionado a ele para que posteriormente fossem exibidos junto com este conteúdo. Os links podiam ser acessados livremente pelos alunos, diretamente pelas páginas de conteúdo, mas nenhuma ferramenta de mapeamento ou de armazenamento de informações a respeito dos acessos foi utilizada nestes links.

A listagem completa dos links utilizados encontra-se no Anexo E. Os critérios adotados para a escolha dos links foram: existência de vínculo com instituições reconhecidas como confiáveis no meio acadêmico; existência de elevado potencial para se manterem 
sempre no mesmo endereço; existência de relação entre o conteúdo disponível a partir do acesso ao link e tópicos ministrados na disciplina em questão. Desta forma, encontravam-se disponíveis no sítio apresentações em PowerPoint, arquivos "PDF" e páginas HTML que continham explicações textuais e pictóricas dos assuntos abordados na disciplina, em uma linguagem que consideramos como acessível aos estudantes. Os links reproduzidos no Anexo E foram separados conforme as áreas em que foram exibidos no sítio, de forma semelhante aos verbetes do Glossário, apresentado no Anexo D.

\subsection{O bate-papo}

Um bate-papo também foi disponibilizado no sítio para que fosse utilizado em monitorias, executadas via Web em dias e horários pré-estabelecidos. O aplicativo do batepapo é fornecido pelo provedor comercial utilizado, não sendo necessária nenhuma instalação ou configuração. O aplicativo permitiu apenas a abertura de uma sala sem permissão de conversas paralelas ou ocultas. Assim foi possível evitar conversas entre alunos, direcionando a discussão para assuntos escolhidos pelo estagiário, que fazia o papel de mediador das conversas.

No início do semestre letivo, ambas as turmas tomaram conhecimento de que, em dois dias por semana, durante 1 hora, um estagiário estaria disponível na sala de bate-papo para tirar dúvidas dos alunos em tempo real. Apenas três sessões de monitoria foram executadas via bate-papo. A primeira, mediada pelo estagiário da Turma 2, foi a única em que os estudantes compareceram e após duas monitorias sem a presença de nenhum estudante, optamos pela não realização de outras monitorias. 
Cabe ressaltar que monitorias via sala de bate-papo foram as únicas oferecidas aos estudantes. Monitorias presenciais não foram oferecidas e as dúvidas referentes às práticas eram sanadas em conversas informais nas dependências do Instituto com os estagiários.

A Figura 30 mostra uma das telas obtidas na monitoria. A conversa trata do cálculo da porcentagem de ácido acético em vinagre e a interação aluno-estagiário ocorre durante a realização do cálculo da referida porcentagem. Verificamos que, apesar da impossibilidade de utilização, por parte de ambos, de sobrescrito, subscrito, e outras formatações necessárias à comunicação em química, algumas formalidades foram negligenciadas, substituindo-se termos complexos por abreviações e outras formas de transcrições, de tal forma que as dúvidas do aluno foram sanadas via Web.

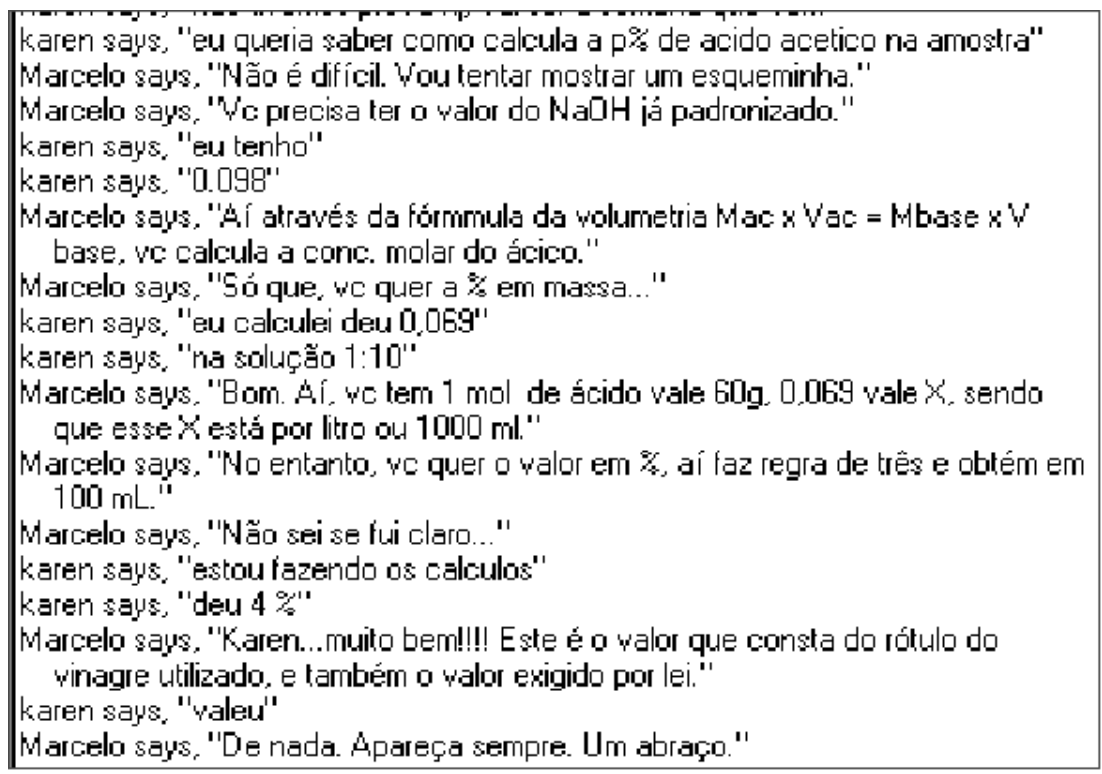

Figura 30: Transcrição da primeira sessão de monitoria via Internet realizada na disciplina.

Apesar da monitoria virtual ter se mostrado eficiente para atingir o fim a qual havia sido destinada; aparentemente, as interações presenciais parecem ter recebido a preferência dos estudantes, que não se sentiram motivados a participar destes encontros. 


\subsection{Análise do questionário de avaliação do sítio}

Com o intuito de conhecermos as impressões dos alunos sobre o conteúdo e a utilização do sítio, após a conclusão das atividades da disciplina solicitamos que respondessem a um questionário que estava dividido em três partes: a primeira parte composta de 16 afirmações relacionadas aos construtos do Modelo de Aceitação de Tecnologia ${ }^{45}$; a segunda composta por 4 afirmações relacionadas ao valor pedagógico do sítio e a terceira composta por 3 afirmações relacionadas à satisfação com a utilização do sítio. Para que as respostas por eles apresentadas fossem quantificadas e analisadas, foi utilizada escala Likert de 5 pontos com alternativas: Concordo Fortemente, Concordo, Indeciso, Discordo, Discordo Fortemente. Um total de 18 estudantes respondeu voluntariamente o questionário. Comentaremos inicialmente as últimas 7 afirmações e posteriormente comentaremos aquelas que foram construídas levando em conta o $\mathrm{MAT}^{45}$.

As últimas afirmações, contidas na segunda parte do questionário, e utilizadas para que especulações sobre o valor pedagógico do sítio pudessem ser feitas encontram-se reproduzidas na Figura 31. A primeira afirmação visa especular sobre o potencial do sítio para ensinar conceitos novos aos alunos enquanto que as outras 3 visam conhecer o seu potencial para ajudar no entendimento de conceitos já vistos. A Figura 31 sintetiza os resultados obtidos a partir da análise das respostas dadas às 4 afirmações relacionadas ao valor pedagógico do sítio. 


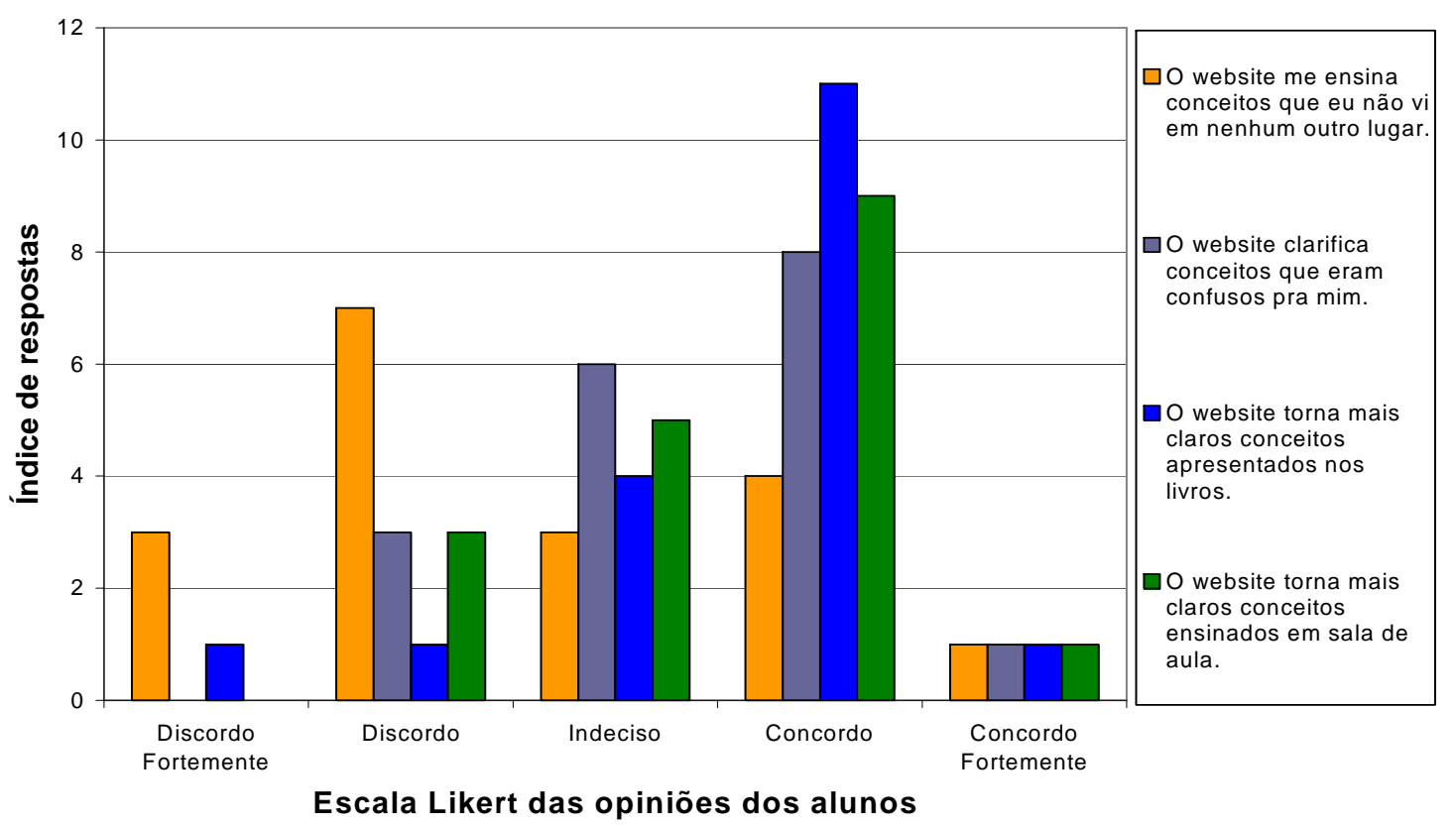

Figura 31: Índice de respostas em escala Likert de cinco pontos para as quatro afirmações. Cada barra vertical mostra o número de respostas para cada opção em cada uma das afirmações.

A análise dos dados obtidos para a primeira afirmação indica que $55.6 \%$ das respostas se concentram nas opções Discordo e Discordo Fortemente. Este resultado não é surpreendente, uma vez que o sítio foi construído com o intuito de oferecer material suplementar ao ensino dos tópicos ministrados no laboratório e não com o objetivo de proporcionar ao usuário a capacidade de desenvolver um aprendizado independente. A análise dos dados obtidos para as demais afirmações, que visam avaliar o sítio como material suplementar, ou seja, se o sítio pode melhorar o entendimento de conceitos já vistos, indicam que existe uma forte tendência à alternativa Concordo. Estes resultados sugerem que o sítio atende ao objetivo principal a que se propõe, sendo útil no auxílio ao entendimento de conceitos já vistos pelos estudantes.

As 3 afirmações, incluídas na terceira parte no questionário, concernentes à satisfação com a utilização do sítio, encontram-se contidas na Figura 32 e os dados obtidos a partir da sua análise encontram-se sintetizados no gráfico ilustrado na mesma Figura. 


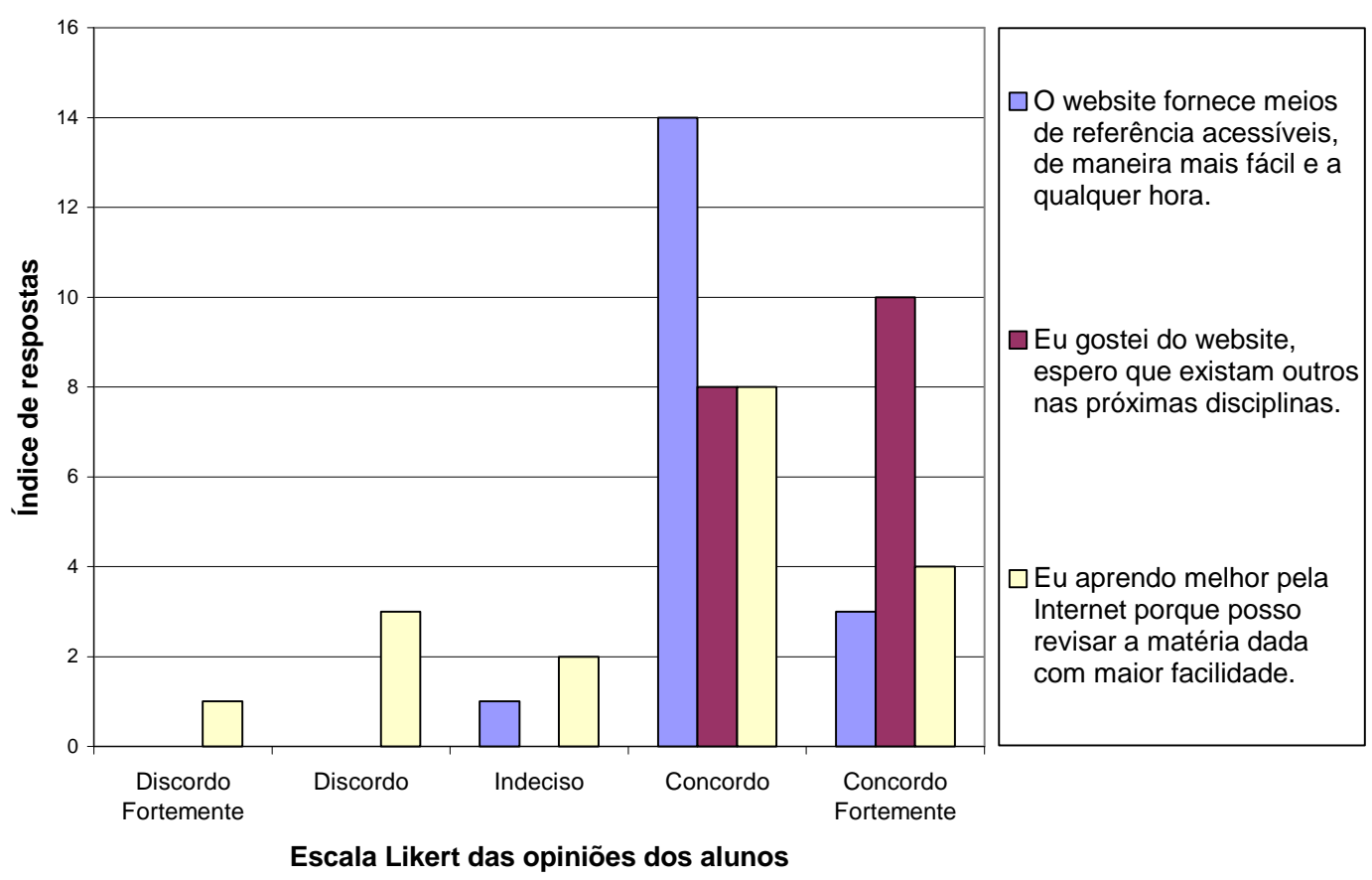

Figura 32: Índice de respostas em escala Likert de cinco pontos para as 3 afirmações. Cada barra vertical mostra o número de respostas para cada opção em cada uma das afirmações.

Os resultados mostram que 94,4\% dos alunos (somatório das respostas Concordo e Concordo Fortemente) acreditam que o sítio fornece meios de referência acessíveis facilmente. Pode-se perceber também, devido à ausência de opiniões contrárias ou indiferentes, que $100 \%$ dos participantes esperam iniciativas como esta em disciplinas futuras. Com relação à terceira afirmativa, verifica-se uma divergência maior nas opiniões, uma vez que apenas $66,7 \%$ dos alunos (somatório das respostas Concordo e Concordo Fortemente) ainda acreditam aprender melhor com o uso de material disponível na Internet.

Conforme mencionamos anteriormente, parte das afirmações contidas no questionário de avaliação do sítio foram elaboradas tomando por base o $\mathrm{MAT}^{45}$, sendo 6 afirmações relacionadas ao construto Utilidade Percebida, 6 relacionadas ao construto Facilidade de Uso Percebida, e 4 afirmações relacionadas ao Uso Real do sistema. Os resultados obtidos a partir da análise das respostas dos alunos encontram-se sintetizados nas Figuras 33, 34 e 35. Vale lembrar que as 16 afirmações (indicadores) foram traduzidas na 
íntegra do trabalho de Selim ${ }^{45}$ e aplicadas em nosso estudo de forma a captar as impressões pessoais dos alunos sobre a aceitação do sítio de Internet.

\subsubsection{Construto Utilidade Percebida}

Com relação às 6 afirmações que versam sobre o construto Utilidade Percebida (questões de 1 a 6 do anexo C), a análise das respostas dos alunos nos permitiu construir o gráfico da Figura 33. Cada uma das afirmações relacionadas a este construto (destacadas em itálico no texto) serão discutidas a seguir.

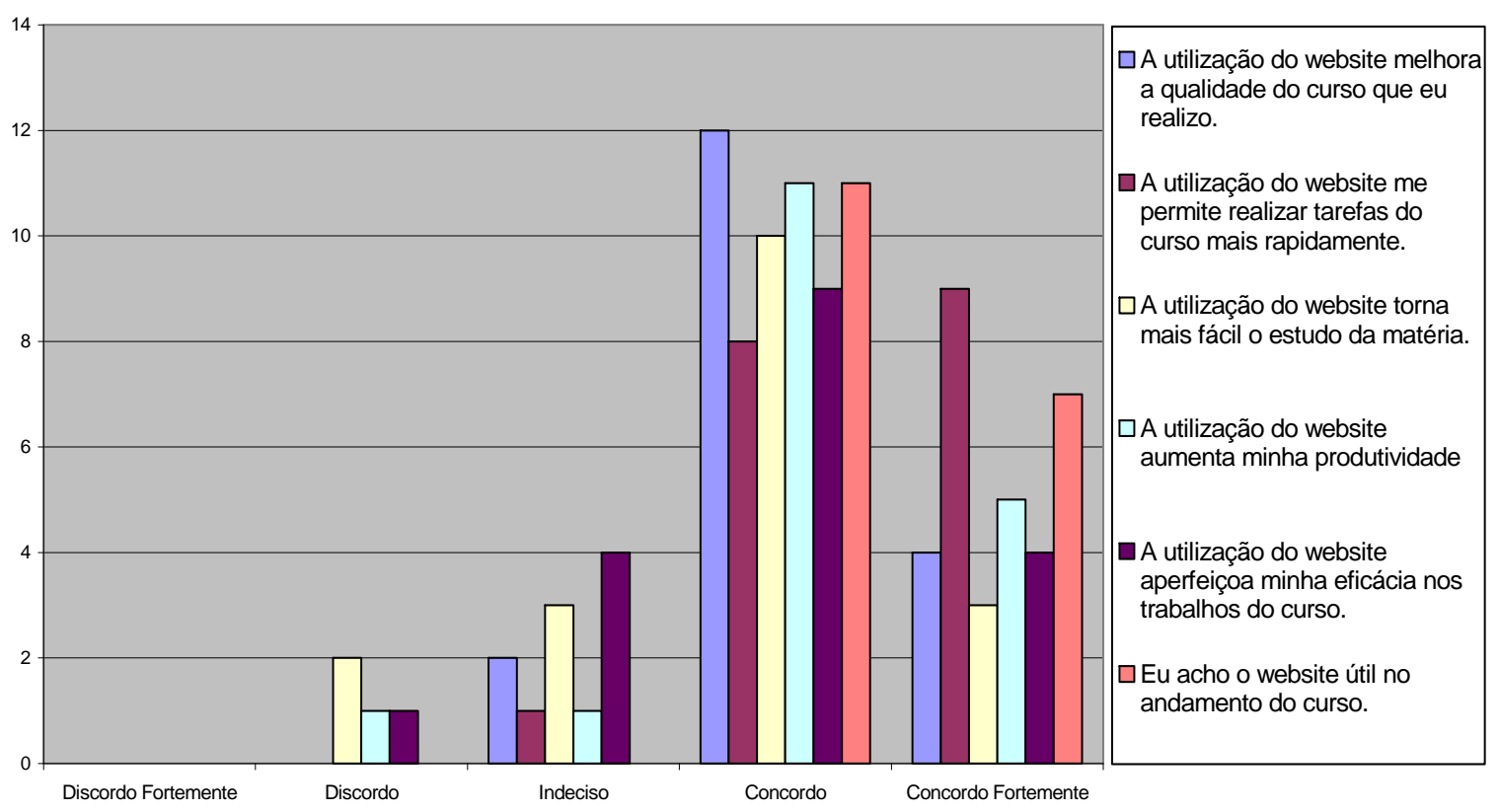

Figura 33: Índice de respostas em escala Likert de cinco pontos para as 6 afirmações relativas ao construto Utilidade Percebida do $\mathrm{MAT}^{45}$. As barras verticais mostram o número de respostas para cada opção em cada uma das afirmações. As afirmações são reproduzidas no gráfico na ordem em que foram respondidas pelos alunos. Barras que não tenham correspondentes na legenda representam índice 0 de respostas.

\section{- A utilização do Website melhora a qualidade do curso que eu realizo}

Verificamos que nenhum dos alunos discorda desta afirmação e, com exceção de $11,1 \%$ dos alunos que se mostraram indecisos, todos os demais $(88,9 \%)$ concordam ou concordam fortemente que o sítio é útil na melhoria da qualidade do curso que realizam. 
- A utilização do Website me permite realizar tarefas do curso mais rapidamente

Assim como no caso da afirmação anterior, verificamos que nenhum dos alunos discorda desta afirmação. Com exceção de 5,6\% dos alunos que se mostraram indecisos, 94,4\% (somatório das respostas Concordo e Concordo Fortemente) acreditam que o sítio agiliza a realização de tarefas relacionadas à disciplina.

- A utilização do Website torna mais fácil o estudo da matéria

Com relação a esta afirmação, verificamos que 72,2\% dos alunos (somatório das respostas Concordo e Concordo Fortemente) acreditam que o uso do sítio facilita o estudo do conteúdo. No entanto, $11,1 \%$ discordam desta afirmação e 16,7\% mostraram-se indecisos sobre esta afirmação.

\section{- A utilização do Website aumenta minha produtividade}

Com relação a esta afirmação, verificamos que 88,9\% dos alunos (somatório das respostas Concordo e Concordo Fortemente) acreditam que a utilização do sítio aumenta sua produtividade. No entanto, 5,6\% discordam desta afirmação e 5,6\% mostraram-se indecisos sobre esta afirmação.

- A utilização do Website aperfeiçoa minha eficácia nos trabalhos do curso

Com relação a esta afirmação, verificamos que 72,2\% dos alunos (somatório das respostas Concordo e Concordo Fortemente) acreditam que a utilização do sítio melhora sua eficácia nos trabalhos do curso. No entanto, 5,6\% discordam desta afirmação e 22,2\% mostraram-se indecisos sobre esta afirmação. Assim, esta foi a afirmação que apresentou o maior índice de respostas para a opção Indeciso e o menor índice de concordância ou concordância parcial. 
- Eu acho o Website útil no andamento do curso

Para esta afirmação que, devido ao seu caráter geral, no nosso entender é bastante reveladora, verificamos que nenhum alunos se mostrou indeciso a seu respeito e que $100 \%$ (somatório das respostas Concordo e Concordo Fortemente) acreditam na utilidade do sítio no andamento do curso.

Os resultados nos mostram que $87,6 \%$ das respostas dadas às seis afirmações relacionadas ao construto Utilidade Percebida do MAT se concentram nas opções Concordo e Concordo Fortemente, o que sugere que, de uma maneira geral, os alunos acreditam na utilidade do sítio como ferramenta capaz de os auxiliar no andamento do curso.

\subsubsection{Construto Facilidade Percebida}

Com relação às 6 afirmações que versam sobre o construto Facilidade Percebida (questões de 7 a 12 do anexo C), a análise das respostas dos alunos nos permitiu construir o gráfico da Figura 34. Cada uma das afirmações relacionadas a este construto (destacadas em itálico no texto) serão discutidas a seguir. 


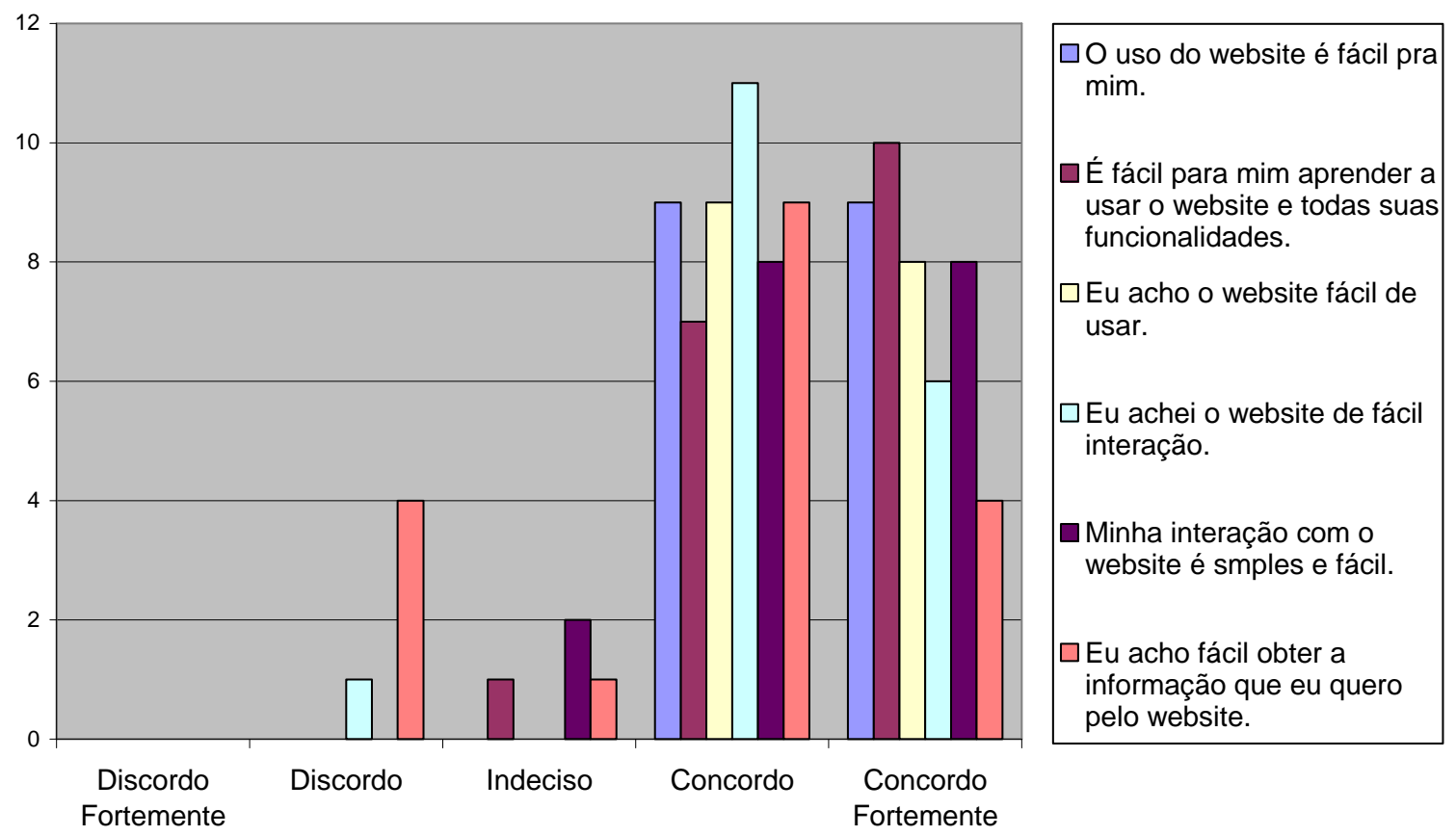

Figura 34: Índice de respostas em escala Likert de cinco pontos para as 6 afirmações relativas ao construto Facilidade Percebida do $\mathrm{MAT}^{45}$. Cada barra vertical mostra o número de respostas para cada opção em cada uma das afirmações.

- O uso do Website é fácil para mim

Verificamos que nenhum dos alunos discorda desta afirmação ou mostra-se indeciso a seu respeito. Todos concordam que o sítio é de fácil utilização.

\section{- É fácil para eu aprender a usar o Website e todas as suas funcionalidades}

Assim como no caso da afirmação anterior, verificamos que nenhum dos alunos discorda desta afirmação. Com exceção de 5,6\% dos alunos que se mostraram indecisos, 94,4\% (somatório das respostas Concordo e Concordo Fortemente) acreditam que é fácil aprender a usar o Website e suas funcionalidades.

\section{- Eu achei o Website de fácil interação}

Nenhum aluno mostrou-se indeciso com relação a esta afirmação e apenas 5,6\% dos alunos discordam da mesma. Os demais $(94,4 \%)$ acreditam ser fácil a interação com o sítio. 
- Minha interação com o Website é simples e fácil

Verificamos que nenhum dos alunos discorda desta afirmação e que 11,2\% mostram-se indecisos a seu respeito. Os demais $(88,8 \%)$ afirmam interagir com o sito de maneira simples e fácil.

- Eu acho fácil obter a informação que eu quero pelo Website

Com relação a esta afirmação, verificamos que 72,2\% dos alunos (somatório das respostas Concordo e Concordo Fortemente) acreditam ser fácil obter a informação desejada pelo Website. No entanto, 22,2\% discordam desta afirmação e 5,6\% mostraram-se indecisos sobre esta afirmação. Desta forma, verificamos um alto índice de discordância por parte dos alunos no que diz respeito a esta afirmação, quando comparado aos outros indicadores do mesmo construto.

Os resultados nos mostram que $90,7 \%$ das respostas dadas às seis afirmações relacionadas ao construto Facilidade Percebida do MAT se concentram nas opções Concordo e Concordo Fortemente, o que nos sugere que os alunos, de maneira geral, consideram o sítio fácil de usar no contexto da disciplina.

\subsubsection{Construto Uso Real do Sítio}

Com relação às 4 afirmações que versam sobre o construto Uso Real do Sítio (questões de 13 a 16 do anexo C), a análise das respostas dos alunos nos permitiu construir o gráfico da Figura 35. Cada uma das afirmações relacionadas a este construto (destacadas em itálico no texto) serão discutidas a seguir. 


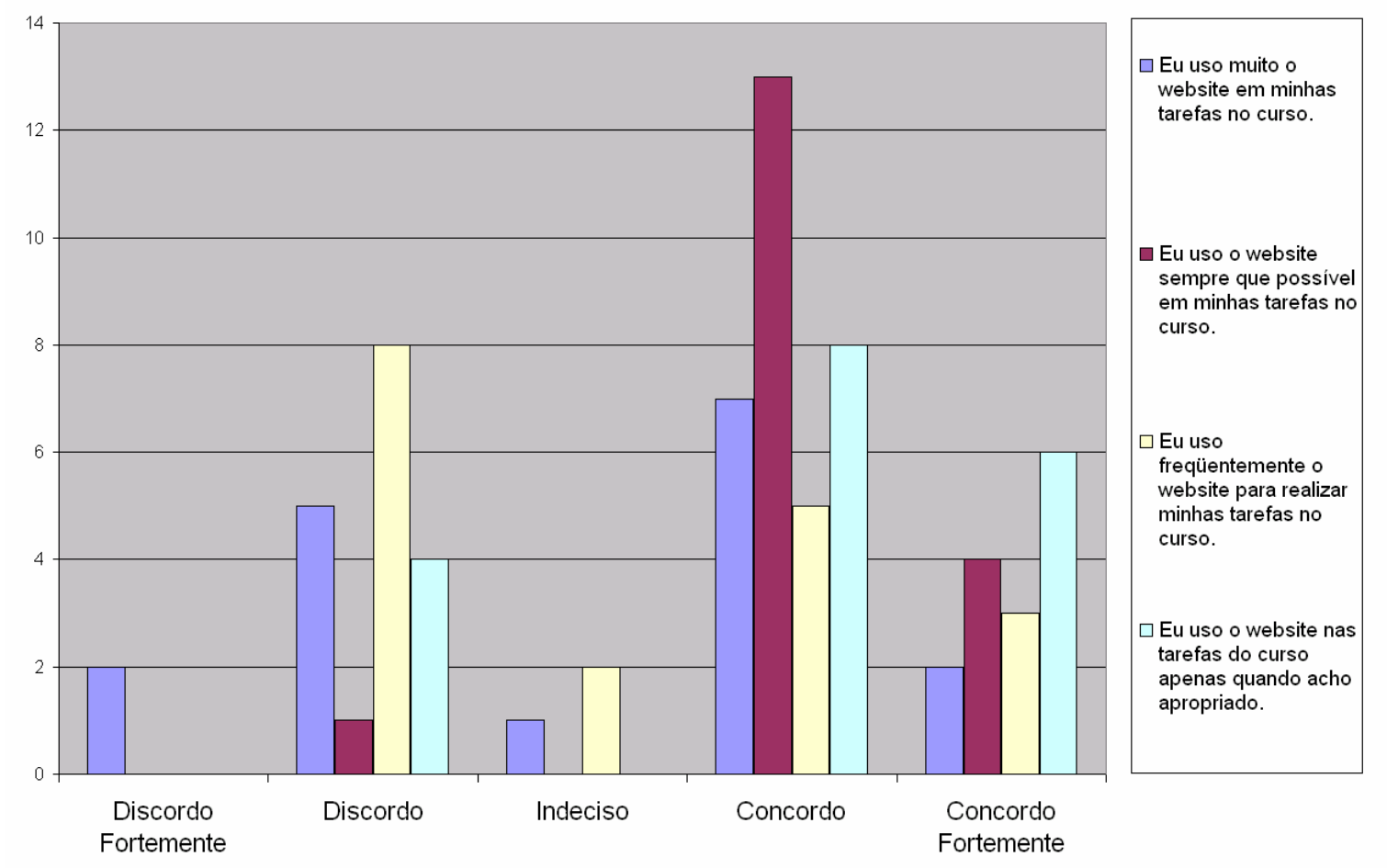

Figura 35: Índice de respostas em escala Likert de cinco pontos para as 4 afirmações relativas ao construto Uso Real do modelo MAT $^{45}$. Cada barra vertical mostra o número de respostas para cada opção em cada uma das afirmações. As afirmações que não encontram correspondentes no gráfico indicam ausência de resposta.

\section{- Eu uso muito o Website em minhas tarefas no curso}

Com relação a esta afirmação, percebemos uma clara divisão entre os alunos que afirmam usar muito o sítio (53\%) e os que não concordam completamente com esta afirmativa (41\%), se compararmos opiniões negativas (somatória das opiniões Discordo e Discordo Fortemente) com as opiniões positivas (somatória das opiniões Concordo e Concordo Fortemente).

\section{- Eu uso o Website sempre que possível em minhas tarefas no curso}

Verificamos que nenhum dos alunos se mostra indeciso quanto a esta afirmação e que apenas 5,6\% discordam da mesma. Os demais $(94,4 \%)$ afirmam usar o Website sempre que possível nas tarefas do curso. 
- Eu uso freqüentemente o Website para realizar minhas tarefas no curso

Assim como no caso da primeira afirmação deste construto, percebemos uma clara divisão entre os alunos que afirmam usar freqüentemente o sítio e os que não concordam completamente com esta afirmação se compararmos opiniões negativas (somatória das opiniões Discordo e Discordo Fortemente) com as opiniões positivas (somatória das opiniões Concordo e Concordo Fortemente). Verificamos que 44,4\% dos alunos não usam o sítio freqüentemente na resolução das tarefas do curso, e a mesma porcentagem $(44,4 \%)$ que freqüentemente utilizam o sítio com este fim. Os indecisos para esta afirmativa somam $11,2 \%$.

- Eu o Website nas tarefas no curso apenas quando acho apropriado

Verificamos que nenhum dos alunos se mostra indeciso quanto a esta afirmação e que apenas $22,2 \%$ discordam da mesma. Os demais (77,8\%) afirmam usar o sítio apenas quando acham apropriado, o que sugere a busca de informações específicas por parte dos alunos e confirma o valor do sítio como material suplementar à disciplina.

Os resultados nos mostram que $66,7 \%$ das respostas dadas às quatro afirmações relacionadas ao construto Uso Real do Sítio do $\mathrm{MAT}^{45}$ se concentram nas opções Concordo e Concordo Fortemente. O baixo índice de respostas concordantes para este construto não surpreende, visto que frente ao $\mathrm{MAT}^{45}$, o Uso Real é diretamente influenciado pela Utilidade Percebida e indiretamente influenciado pela Facilidade Percebida ${ }^{45}$. Assim, podemos afirmar que as respostas negativas fornecidas por estudantes aos outros dois construtos influenciam o Uso Real de forma negativa provocando a maior dispersão nas opiniões como observado na Figura 34. 


\subsection{Afirmações relacionadas ao MAT presentes no questionário de avaliação: resultados preliminares obtidos por análise fatorial}

Além da análise descritiva das afirmações relacionadas ao $\mathrm{MAT}^{45}$ presentes no questionário de avaliação, realizamos testes de verificação da viabilidade da realização da análise fatorial para os mesmos dados. De maneira geral, a análise fatorial é um método de redução de dados que busca explicar variáveis não observáveis (fatores) a partir de variáveis observáveis (indicadores). Este método busca um padrão de resultados onde os indicadores influenciam em apenas 1 fator (construto) ${ }^{84}$.

A análise fatorial é aplicada ao MAT quando correlacionamos um construto para cada fator e uma afirmação a cada indicador, visando predizer a maneira com que um certo construto influencia uma série de indicadores ${ }^{85}$. Não existe um número mínimo de medidas a serem consideradas na realização da análise fatorial. Entretanto, um conjunto de dados maior produz melhores resultados. Em nosso caso aplicamos 16 indicadores (afirmações do questionário de avaliação) medidos a partir das respostas de 18 estudantes. Este é um conjunto de dados extremamente pequeno que nos leva a esperar um ajuste pobre ao modelo escolhido, visto que nos pautamos no trabalho de $\operatorname{Selim}^{45}$, que obteve 403 respostas utilizando os mesmos indicadores. Ainda assim, alguns trabalhos reportados na literatura tratam de iniciativas que utilizam a análise fatorial aplicada ao MAT em amostras pequenas, como no caso de Lee e colaboradores ${ }^{86}$. Estes autores aplicaram a análise fatorial na avaliação de um projeto de ensino à distância, baseado na Web, que visava desenvolver a capacidade de 31 estudantes em interagirem efetivamente no desenvolvimento de sistemas aeroespaciais. 
Basicamente, existem dois tipos de análise fatorial: exploratória e confirmatória. A primeira busca descobrir a natureza dos construtos que influenciam uma série de respostas e a segunda testa se uma série de construtos influencia as respostas de forma prevista ${ }^{85}$.

Com o intuito de verificarmos a possibilidade da realização da análise fatorial exploratória para os nossos dados aplicamos dois testes globais: o valor do determinante ${ }^{84} \mathrm{e}$ a medida de adequação da amostra de Kaiser-Meyer-Olkin $(\mathrm{KMO})^{84}$, utilizando o software SPSS (versão 9.0).

O valor do determinante permite prever se existirão erros na realização da análise ${ }^{84}$. Caso seu valor seja 0 é sugerido que a análise não seja completada. Em nosso caso o determinante é $5,226 \times 10^{-14}$, valor extremamente próximo de zero (0). Podemos afirmar com isso que, a princípio, análise fatorial exploratória não deve ser feita, pois caso seja realizada, os resultados obtidos não traduzirão a realidade.

Ainda assim, com o intuito de confirmar a indicação de que a análise fatorial não deveria ser realizada, realizamos o teste $\mathrm{KMO}^{85}$. Esta medida varia de 0 a 1 e valores próximos a 1 são sempre desejados, sendo o valor 0,6 considerado o mínimo para a realização da análise. Em nosso caso o valor KMO, extraído pelo software SPSS, é de 0,276.

Tomados em conjunto, os testes apontam requisitos mínimos que devem ser satisfeitos antes que uma análise fatorial seja realizada ${ }^{84}$. Os resultados obtidos para nosso conjunto de dados sugerem a inviabilidade da execução da análise fatorial, que podem ser explicados pela baixa adequação do instrumento de pesquisa (survey) associado ao pequeno espaço amostral. Ainda assim obtivemos a média e desvio padrão para cada item dos construtos e também o Alfa de Chronbach $(\alpha)$ visando estimar a confiabilidade do nosso instrumento de pesquisa. 
A Tabela 6 exibe os valores da média e desvio padrão para cada indicador analisado e o Alfa de Chronbach para cada construto. Hair, Anderson, Tatham, and Black ${ }^{87}$ sugerem que o valor aceitável para o alfa é no mínimo 0.70. Como mostrado na tabela, os construtos Utilidade Percebida e Facilidade de Uso Percebida exibem um bom grau de consistência interna visto que os valores obtidos são respectivamente 0,71 e 0,80 . Já o valor de 0,37 obtido para o construto Uso Real mostra que ele, a priori, não pode ser utilizado na análise, visto que não exibe consistência interna aceitável. Considerando então o valor do Determinante, o índice KMO e o Alfa de Chronbach, obtido para o construto Uso Real, optamos pela não continuidade da análise fatorial exploratória.

Tabela 6: Médias, desvios-padrão e Alfa de Chronbach para itens e construtos do MAT.

\begin{tabular}{|c|c|c|c|c|}
\hline CONSTRUTO & ITEM & MÉDIA & $\begin{array}{c}\text { DESVIO } \\
\text { PADRAO }\end{array}$ & ALPHA \\
\hline UPCW & $\begin{array}{l}\text { UP1 } \\
\text { UP2 } \\
\text { UP3 } \\
\text { UP4 } \\
\text { UP5 } \\
\text { UP6 }\end{array}$ & $\begin{array}{l}4,1111 \\
4,4444 \\
3,7778 \\
4,1111 \\
3,8889 \\
4,3889\end{array}$ & $\begin{array}{l}, 5830 \\
, 6157 \\
, 8782 \\
, 7584 \\
.8324 \\
5016\end{array}$ & 0,71 \\
\hline$\overline{\text { FPCW }}$ & $\begin{array}{l}\text { FP1 } \\
\text { FP2 } \\
\text { FP3 } \\
\text { FP4 } \\
\text { FP5 } \\
\text { FP6 }\end{array}$ & $\begin{array}{l}4,5000 \\
4,5000 \\
4,3889 \\
4,2222 \\
4,3333 \\
3,7222\end{array}$ & $\begin{array}{l}5145 \\
.6183 \\
6077 \\
, 7321 \\
68600 \\
1.0741\end{array}$ & 0,80 \\
\hline$\overline{\text { URCW }}$ & $\begin{array}{l}\text { UR1 } \\
\text { UR2 } \\
\text { UR3 } \\
\text { UR4 }\end{array}$ & $\begin{array}{l}3,1111 \\
4,1111 \\
3,1667 \\
3,8889\end{array}$ & $\begin{array}{c}1,2783 \\
, 6764 \\
1,2005 \\
1,13\end{array}$ & 0,37 \\
\hline
\end{tabular}

As médias gerais para cada construto, que também fornecem alguns indicativos, são: 4,12 para a Utilidade Percebida; 4,28 para a Facilidade Percebida; 3,57 para o Uso Real. Considerando que o maior valor que pode ser obtido é 5 , o valor alto para a média do construto Utilidade Percebida pode ser justificado se considerarmos uma das perguntas feita no Questionário de Caracterização do Aluno. Conforme mencionamos anteriormente, 93,5\% de nossos alunos acreditam que a implantação de material suplementar via Internet pode 
aumentar seu desempenho na disciplina. Esta expectativa é discutida no trabalho de Lee e colaboradores $^{86}$. Segundo estes autores, a expectativa do aumento de performance possui um relacionamento estatístico significativo com a Utilidade Percebida, influenciando direta e positivamente neste construto.

Na mesma direção apontada por Lee e colaboradores ${ }^{86}$, Selim $^{45}$ apresenta 4 fatores determinantes, de influência positiva, no construto Utilidade Percebida, sendo eles: a interatividade (existência de ferramentas que possibilitem a interação entre os envolvidos na aplicação e utilização de cursos via Web, como um fórum de discussão), a possibilidade de cumprimento de tarefas rapidamente (provendo os estudantes com animações e módulos multimídia, por exemplo), a facilidade no estudo do material (tornando-o disponível a qualquer hora em qualquer lugar, por exemplo) e aumento na produtividade e efetividade (fornecendo aos estudantes ferramentas que façam com que finalizem o curso rapidamente e que atinjam seus objetivos). Vale salientar que dos 4 fatores apresentados por Selim ${ }^{45}$, apenas 3 foram aplicados em nosso sítio visto que não houve tempo hábil para a construção de animações e módulos multimídia. Ainda assim nossos dados permitem dizer que a grande expectativa dos alunos na utilização do sítio, associada a 3 dos 4 fatores acima apresentados auxiliou no aumento da Utilidade Percebida, influenciando de maneira direta o Uso Real do sistema.

De forma semelhante, podemos citar a média geral obtida para o construto Facilidade de Uso Percebida (4,28). Este valor pode ser justificado também quando analisamos uma pergunta feita no Questionário de Caracterização do Aluno. Quando questionados sobre a melhor alternativa para traduzir sua relação com a Internet, $62 \%$ dos alunos afirmam conseguirem mais do que necessitam ou sentirem completamente confortáveis com seu uso. Como afirmam Lee e colaboradores ${ }^{86}$, diversão, usabilidade, e 
apreciação são motivações intrínsecas que influenciam diretamente a Facilidade Percebida de Uso. Assumindo a sensação de conforto citada por $62 \%$ de nossos alunos também como uma motivação intrínseca, podemos afirmar que ela influencia de maneira positiva e direta a Facilidade Percebida de Uso justificando o valor encontrado para a média geral deste construto e também para a Utilidade Percebida que é diretamente influenciada por ele.

Ainda nesta perspectiva, $\operatorname{Selim}^{45}$ afirma que os determinantes críticos para a Facilidade de Uso Percebida podem ser agrupados em três categorias: Consistência, Flexibilidade e Entendimento. A Consistência pode ser obtida dando-se atenção a conceitos similares, gráficos, estrutura navegacional e lay-out da aplicação. A Flexibilidade é obtida quando estudantes de níveis diferentes podem usar a mesma aplicação obtendo resultados também em níveis diferentes, e o Entendimento pode ser considerado como a busca e o uso de informação específica e relevante pelos alunos. Acreditamos ter contemplado todos os fatores determinantes à Facilidade de Uso Percebida na construção do nosso sítio. Impressão esta apoiada pelo fato do valor da média geral para o construto Facilidade de Uso Percebida ser o mais alto dos três.

Com relação ao construto Uso Real do sistema, também podemos fazer algumas especulações. O valor de média geral em 3,57 não é tão alto se considerarmos que este construto é diretamente influenciado pela Utilidade Percebida e indiretamente influenciado pela Facilidade de Uso Percebida. Conforme afirmam Lee e colaboradores ${ }^{86}$, os estudantes tendem a formar suas atitudes, baseados em impressões iniciais das características percebidas para a tecnologia, e que o sucesso deste tipo de iniciativa depende do desenvolvimento de uma atitude positiva com relação ao uso da tecnologia. Em seu trabalho os autores afirmam que os estudantes tendem a perceber (conforme utilizam) falhas na tecnologia em questão, o que leva a uma mudança de atitude no decorrer do semestre, reduzindo o valor para a média 
geral do Uso Real do sistema. Em nosso caso, observamos que no decorrer do semestre, mais relatórios foram enviados pela ferramenta disponibilizada e um número maior de visitas foi verificado nas páginas de conteúdo, em especial nas páginas relativas à terceira área (Análise Volumétrica). Os fatos nos permitem sugerir que a mudança de atitude ocorrida para os nossos alunos foi positiva e que ainda que tenham presenciado falhas no sistema, estas falhas não influenciaram significativamente o Uso Real.

\subsection{Sugestões apresentadas pelos alunos para a melhoria do sítio e modificações nele implementadas}

Conforme mencionamos anteriormente, uma questão dissertativa que solicitava sugestões que levassem à melhoria do sítio foi inserida no Questionário de Avaliação do Sítio. Apenas 4 sugestões foram apresentadas e encontram-se reproduzidas a seguir:

5. Fornecer as notas dos relatórios enviados através do site. Fornecer dados a respeito de constantes de equilíbrio, etc. Pôr comentários a respeito do desempenho dos alunos nos relatórios.

6. Falta algum atrativo alem de envios de relatórios onde exista maior interação dos alunos com o sitio.

7. Se possível uma maior quantidade de material disponível para consulta e um recibo que possa ser impresso se necessário do envio do relatório.

8. No geral o Website é muito útil. Porém ainda existem certos problemas como os que ocorreram comigo. Duas vezes mandei relatório para a professora da Turma 2 pelo Website e os dois não chegaram para ela. Tirando isso o Website é muito funcional e pode melhorar muito mais. Mas sua principal utilização é para enviar relatórios o que deve ser feito com sucesso, estando o site sempre funcionando corretamente e sem defeitos.

As sugestões dos alunos e análise das respostas por eles apresentadas às demais questões do Questionário de Avaliação do Sítio foram por nós consideradas Assim, concluído o semestre letivo em que coletamos os dados para a nossa dissertação, fizemos algumas modificações na estrutura do sítio. Para tanto, levamos ainda em conta observações feitas por 
membros da nossa banca de qualificação. Estas modificações encontram-se justificadas e descritas a seguir.

Delineamos o sítio de tal maneira que permitisse uma abordagem mais participativa por parte dos alunos; assim em sua última versão, o sítio permite que os próprios estudantes cadastrados adicionem links e verbetes de glossário relacionados ao tópico de estudo. Estes links e verbetes podem ser agora validados por um administrador e exibidos diretamente no tópico em que foram inseridos e não em outra página (como acontecia anteriormente no caso do Glossário). Os links e verbetes adicionados são ainda acompanhados do nome do autor. Esperamos assim que, em futuras iniciativas, que o estudante perceba que também é responsável pela construção do sítio e participe de maneira mais ativa.

Outra melhoria importante foi a exibição dos relatórios enviados na página de Rosto de cada estudante, assim, após o envio de um relatório, o estudante continua sendo enviado à Página de Rosto, podendo então verificar se o seu relatório foi adicionado à base de dados. 


\section{CONSIDERAÇÕES FINAIS}

Este trabalho concentrou-se na elaboração, aplicação e avaliação de um sítio de Internet como meio de apoio às atividades da disciplina de Laboratório de Química Analítica Quantitativa. De maneira geral, os resultados sugerem boa aceitação do sítio por parte dos estudantes envolvidos na pesquisa tanto pelo método de monitoramento quanto pela avaliação de suas percepções próprias.

Os métodos de análise utilizados sugerem resultados interessantes, pois frente a navegação realizada pelos alunos e algumas questões postadas no fórum de discussão, concluímos que os estudantes são capazes de estabelecer relações entre os tópicos, e também de localizar no conteúdo os tópicos de maior dificuldade, ao contrário do que havia sido verificado por Tissue ${ }^{10}$ e Weaver ${ }^{28}$. Acreditamos que estes resultados possam ser explicados pela estrutura modular do conteúdo, que permite ao estudante maior liberdade na decisão de que tópico prosseguir.

Podemos constatar também que uma interface gráfica amigável associada a exibição de pouco conteúdo auxilia no que chamamos de Facilidade Percebida de Uso, influenciando direta e positivamente no Uso do sistema.

Outra conclusão importante diz respeito à ferramenta de mapeamento da navegação que frente a nossa análise também poderia ter sido usada com a intenção de identificar dificuldades individuais a fim de promover um auxílio mais direcionado ao estudante no decorrer do semestre conforme sugere Frasier ${ }^{35}$.

No que diz respeito à página Envio de Relatórios, concluímos que iniciativas que possibilitem aumento de performance ou produtividade no decorrer da disciplina, são bem 
aceitas pelos estudantes. O aumento da performance ou produtividade do estudante influi positivamente na Utilidade Percebida do sítio, gerando um impacto positivo no Uso Real.

Com relação à comunicação eletrônica podemos concluir que a utilização de fóruns ou grupos de discussão, são preferíveis que a utilização apenas do e-mail. Em atividades na qual a comunicação face-a-face é privilegiada, a utilização da comunicação eletrônica costuma ser negligenciada.

Concluímos também que a aplicação de recursos Web, no ensino de química requerem treinamento, que devem ser oferecidos aos estudantes e professores envolvidos no processo (antes de sua aplicação), para que sejam aceitas e utilizadas mais facilmente. O tempo também é um fator importante. Iniciativas nesta área requerem um certo tempo de aplicação e utilização para que se consolidem.

E por fim concluímos que iniciativas implementadas para Web efetivamente aumentam o tempo de estudo dedicado pelo aluno, à medida que permite a interação alunoprofessor a qualquer dia ou horário ainda que uma das partes não se encontre na Universidade. 


\section{REFERÊNCIAS BIBLIOGRÁFICAS}

1. YOKAICHIYA, D.K.; GALEMBECK, E.; TORRES, B.B. Adapting a biochemistry course to distance education. Biochemistry and Molecular Biology Education, v. 32, n. 1, p. 27-29, 2004.

2. GERVAY, J.; PARRIL, A.L. Discovery-based stereochemistry tutorials avaible on the World Wide Web. Journal of Chemical Education, v. 74, n. 3, p. 329, 1997.

3. HALL, R.W.; BUTLER, L.G.; MCGUIRE, S.Y.; MCGLYNN, S.P.; LYON, G.L.; REESE, R.L.; LIMBACH, P.A. Automated, Web-based, second-chance homework. Journal of Chemical Education, v. 78, n. 12, p. 1074-1078, 2001.

4. MONTEIRO, L.; NOJIMA, V. A Internet como meio de comunicação: possibilidades e limitações do meio eletrônico. In: CONGRESSO BRASILEIRO DE CIÊNCIAS DA COMUNICAÇÃO, 24., 2001, Campo Grande. São Paulo: Intercom, 2001. p. 08-16.

5. BOSCHMANN, E. Teaching chemistry via distance education. Journal of Chemical Education, v. 80, n. 6, p. 704-708, 2003.

6. HOLMES, C.O.; WARDEN, J.T. CIStudio: a worldwide Web-based, interactive chemical information course. Journal of Chemical Education, v. 73, n. 4, p. 325-331, 1996.

7. MCKELVY, G.M. Preparing for the chemistry laboratory: an Internet presentation and assessment tool. University Chemistry Education, v. 4, n. 2, p. 46-49, 2000.

8. THOMSON, P.A.; JENKINS, J.J.; BUHLER, D.R. Teaching online data systems to graduate students of toxicology. Journal of Chemical Education, v. 72, n. 4, p. 324-326, 1995.

9. CARANDE, R.; HARKANYI, K. Using Internet to disseminate an expert system of chemical information resources. Journal of Chemical Education, v. 72, n. 9, p. 812-813, 1995.

10. TISSUE, B.M. Applying hypermedia to chemical education. Journal of Chemical Education, v. 73, n. 1, p. 65-71, 1996.

11. TISSUE, B.M.; EARP R.; YIP, C. Design and student use of World Wide Web-based prelab exercises. The Chemical Educator, v. 1, n. 1, p. 1-13. 1996. 
12. MOUNTS, R.D. Chemistry on the Web. Journal of Chemical Education, v. 73, n. 1, p. 68-71, 1996.

13. BOCK, J.C.; FRYHLE, C.B.; WALDOW, D.A. CIRRUS: a chemistry Internet resource for research by undergraduate students. Journal of Chemical Education, v. 74, n. 4, p. 441442, 1997.

14. YATES, P.C. World Wide Web publishing as a basis for students projects. University Chemistry Education, v. 2, n. 1, p. 1-4, 1998.

15. KENNEPOHL, D.; BARAN, J.; CURRIE, R. Remote instrumentation for the teaching laboratory. Journal of Chemical Education, v. 81, n. 12, p. 1814-1816, 2004.

16. WHITEPAPER_static_vs_dynamic. Disponível em:

〈www.refreshsoftware.com/F04593029395DE0A/whitepaper_static_vs_dynamic>. Acesso em: 25 set. 2004.

17. CHEMISTRY: webelements periodic table. Disponível em: 〈www.webelements.com/>. Acesso em: 24 set. 2004.

18. MUROV, S. Exploring chemistry resources on the Internet. Journal of Chemical Education, v. 78, n. 10, p. 1429-1431, 2001.

19. WEBSPECTRA - problems in NMR and IR spectroscopy. Disponível em: <www.chem.ucla.edu/ webspectra/>. Acesso em: 25 ago. 2005.

20. MERLIC, C.A.; FAM, B.C.; MILLER, M.M. Webspectra: online NMR and IR spectra for students. Journal of Chemical Education, v. 78, n. 1, p. 118-132, 2001.

21. PORTAL periódicos capes. Disponível em: <www.periodicos.capes.gov.br/>. Acesso em: 25 ago. 2005.

22. SCIELO - scientific eletronic library online. Disponível em: $\leq w w w . s c i e l o . b r />$. Acesso em: 25 ago. 2005.

23. SIBINET. Disponível em: 〈www.sibi.usp.br/sibi/>. Acesso em: 25 ago. 2005.

24. PROBE - programa biblioteca eletrônica. Disponível em: 〈www.probe.br/>. Acesso em: 25 ago. 2005.

25. GIORDAN, M.; DE MELLO, I.C. Serviços de atendimento aos estudantes. Química Nova na Escola, n. 12, p. 8-10, 2000.

26. DORI Y.J.; BARAK, M.; ADIR, N. A Web-based chemistry course as a means to foster freshmen learning. Journal of Chemical Education, v. 80, n. 9, p. 1084-1092, 2003. 
27. ORVIS J.N.; KOEHLER B.P. Internet-based prelaboratory tutorials and computer-based probes in general chemistry. Journal of Chemical Education, v. 80, n. 6, p. 606-608, 2003.

28. WEAVER, G.C. Analysis of student use of a World Wide Web site created as a supplement of general chemistry instruction. The Chemical Educator, v. 2, n. 5, p. 1-17, 1997.

29. CARPI, A. Improvements in undergraduate science education using Web-based instructional modules: The natural science pages. Journal of Chemical Education, v. 78, n. 12, p. 1709-1712, 2001.

30. CRUICKSHANK, B.; FOUST JR., R.D.; STRINGER, M.; ORLANDER, J. The benefits of using Web-based enhancements in an enviromental chemistry class. The Chemical

Educator. v. 4, n. 3, p. 108-111, 1999.

31. STOUT, R.; TOWNS, M.H.; SAUDER, D.; ZIELINSKI, T.H.; LONG G. Online cooperative learning in physical chemistry. The Chemical Educator. v. 1, n. 2, p. 1-21, 1996.

32. GLASER, R.E.; POOLE, M.J. Organic chemistry online: building collaborative learning comunities through eletronic communication tools. Journal of Chemical Education, v. 76, n. 5, p. 699-703, 1999.

33. HANSON, R.M. What's in a name? Journal of Chemical Education, v. 79, n. 11, p. 1380, 2002.

34. HANSON, R.M. The chemical name game. Journal of Chemical Education, v. 79, n. 11, p. $1380,2002$.

35. FRASIER, B.; COLLINS, G.; NEWITT, P. A Web-based interactive homework quiz and tutorial package to motivate undergraduate chemistry students and improve learning. Journal of Chemical Education, v. 80, n. 11, p. 1344-1347, 2003.

36. HANSON, R.M. Hückel determinant solver. Journal of Chemical Education, v. 79, n. 11, p. 1379, 2002.

37. HANSON, R.M. Principal species and $\mathrm{pH}$ in acid-base solutions. Journal of Chemical Education, v. 79, n. 12, p. 1486, 2002.

38. BOKENT, H.; VAN ROOIJ, J.; STUEKER, O.; BRUNBERG, I.; FELS, G. Mol4D: a Web-based computational chemistry interface for educational purposes. Journal of Chemical Education, v. 80, n. 5, p. 582-584, 2003.

39. THE CHEMCOLLECTIVE: virtual lab. Disponível em: 〈www.chemcollective.org/〉. Acesso em: 25 ago. 2005. 
40. PAULISSE, K.W.; POLIK, W.F. Use of WWW discussion boards in chemistry education. Journal of Chemical Education, v. 76, n. 5, p. 704-707, 1999.

41. MAYER, RICHARD E. Cognitive theory and the design of multimedia instruction: an example of the two-way street between cognition and instruction. New Directions for Teaching and Learning. n. 89, p. 55-71, 2002.

42. RADFAHRER, LULI. Design/web/design. 1a edição. São Paulo: Market Press, 1999.

43. WILLIAMS, ROBIN. Design pra quem não é designer: Noções Básicas de Planejamento Visual. $4^{\text {a }}$ edição. São Paulo: Calis, 1995.

44. SILVA, RAFAEL S. Diagramação: O planejamento visual gráfico na comunicação impressa. São Paulo: Summus, 1985.

45. SELIM, H.M. An empirical investigation of student acceptance of course websites. Computers \& Education, n. 40, p. 343-360, 2003.

46. POZO, J.I. Teorias cognitivas da aprendizagem. 3.Ed. Porto Alegre, Artes Médicas, 1998.

47. BADDELEY, A.D. Human memory: Theory and practice. Needham Heights, MA: Allyn \& Bacon. 1990. 423p.

48. JOHNSTONE, A.H. Chemistry teaching—science or alchemy? Journal of Chemical Education, v.74, p.262-268, 1997.

49. MAYER, R.E. Multimedia learning. Cambridge University Press. Cambridge, UK, 2001.

50. RIEBER, L.P. Animation in computer-based instruction. Educational Technology Research \& Development, v.38, n.1, p.77-86, 1990.

51. RENNINGER, K.A.; HIDI, S.; KRAPP, A. The role of interest in learning and development. Erlbaum. Mahwah, NJ, 1992.

52. MOUSAVI, S.Y.; LOW, R.; SWELLER, J. Reducing cognitive load by mixing auditory and visual presentation modes. Journal of Educational Psychology. V.87, n.2, p.319-334, 1995.

53. BARRETO, SAULO F.A.; PIAZZALUNGA, RENATA; RIBEIRO, VIVIANE G.; DALLA, MARIA B.C.; FILHO, ROBERTO M.L. Combining interactivity and improved layout while creating educational software for the web. Computers \& Education, n.40, p.271-284, 2003.

54. FILHO, J. G. Gestalt do Objeto: sistema de leitura visual da forma. São Paulo: Escrituras, 2000 . 
55. DIAS, M.C.; ZWICKER, R.; VICENTIN, I.C. Análise do modelo de aceitação de tecnologia de Davis. Sociedade Paranaense de Ensino e Informática. v. 4, n. 2, p. 15-23, 2003.

56. DAVIS, F.D. Perceived ease of use, and user acceptance of information technology. MIS Quarterly, v. 13, n. 3, p. 319-338, 1989.

57. MATHIESON, K.; PEACOCK, E.; CHIN, W. Extending the technology acceptance model: The influence of perceived user resources. Database for Advances in Information Systems. v. 32, n. 3, p. 86-112, 2001.

58. CHAU, P.Y.K. Influence of computer attitude and self-efficacy on IT usage behavior. Journal of End User Computing. v. 13, n. 1, p. 26-33, 2001.

59. SALEH, Amir Mostafa. Adoção de tecnologia: um estudo sobre o uso de software livre nas empresas. São Paulo, 2004. 149p. Dissertação (Mestrado) - Faculdade De Economia, Administração E Contabilidade, Universidade De São Paulo.

60. VENKATESH, V.; DAVIS, F.D. A theoretical extension of the technology acceptance model: four longitudinal field studies. Management Science, v. 46, n. 2, p. 186-204, 2000.

61. LEE, J.S.; CHO, H.; GAY, G.; DAVIDSON, B.; INGRAFFEA, A. Technology acceptance and social networking in distance learning. Educational Technology \& Society, v. 6 , n. 2 , p. 50-61, 2003.

62. JUPITERWEB. Disponível em:

<http://sistemas1.usp.br:8080/jupiterweb/jupDisciplina?sgldis=SQM0206\&verdis=1>. Acesso em: 04 Out. 2005.

63. APPLICATION Developer's Guide - Deployment. Disponível em:

<http://jakarta.apache.org/tomcat/tomcat-4.1-doc/appdev/deployment.html>. Acesso em: 04 out. 2005.

64. HÉRCULES - Arquitetura MVC. Disponível em: <http://labase.nce.ufrj.br/hercules/arq-

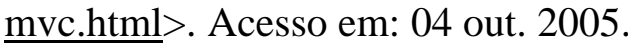

65. PADRÕES de Projeto - O modelo MVC - Model View Controller. Disponível em: <http://www.macoratti.net/vbn_mvc.htm>. Acesso em: 04 out. 2005.

66. BANCO de dados PostgreSQL e MySQL. Disponível em:

<http://www.infowester.com/postgremysql.php>. Acesso em: 04 out. 2005.

67. BANCO de dados._Disponível em:

〈http://www.cic.unb.br/docentes/fernando/matdidatico/apostilas/resumo/bdadossp.pdf >.

Acesso em: 04 out. 2005. 
68. INTRODUÇÃO à linguagem HTML - Tutorial HTML do ICMC-USP. Disponível em: <http://www.icmc.usp.br/ensino/material/html/intro.html>. Acesso em: 04 out. 2005.

69. CASCADING Style Sheets - Wikipédia. Disponível em:

<http://pt.wikipedia.org/wiki/Cascading_style_sheet>. Acesso em: 04 out. 2005.

70. WORLD Wide Web Consortium. Disponível em: <http://www.w3.org/>. Acesso em: 04 out. 2005.

71. LINGUAGEM Java. Disponível em: 〈http://www.infowester.com/lingjava.php >. Acesso em: 04 out. 2005.

72. JAVASCRIPT Introduction. Disponível em: 〈http://www.w3schools.com/js/js_intro.asp $>$. Acesso em: 04 out. 2005.

73. FAQ - Portal Java - A maior comunidade Java do Brasil. Disponível em: $<$ http://www.portaljava.com/home/modules.php?name=FAQ\&myfaq=yes\&id_cat=7\&categor ies $=\mathrm{JSP} \% 2 \mathrm{C}+$ Servlets+e+Tag+Libs $>$. Acesso em: 04 out. 2005.

74. HTMLArea, the Web-based editor [dynarch.com]. Disponível em: <http://www.dynarch.com/projects/htmlarea/>. Acesso em: 04 out. 2005.

75. SWCAT - Artigo 01 - Validador Javascript. Disponível em: <http://www.swcat.com/artigos/javascript/artigo001.php>. Acesso em: 04 out. 2005.

76. LONG, G.; HOWALD, R.;MIDERSKI, C.A.;ZIELINSKI, T.J. Physical chemistry online: a small-scale intercollegiate interactive learning experience. The Chemical Educator. V.1, n. 3, p. 1-17, 1996.

77. CRIPPEN, K.J.; BROOKS, D.W. Teaching advanced placement descriptive chemistry: suggestions from a testing web site. The Chemical Educator. v. 6, n. 5, p. 266-271.

78. POLLARD, J.; TALANQUER, V. Interactive digital overheads: dynamic teaching tools for the chemistry classroom. The Chemical Educator. v. 10, n. 1, p. 36-40, 2005.

79. OLIVIER, G.W.J.; HERSON, K.; SOSABOWSKI, M.H. WebMark--a fully automated method of submission, assessment, grading, and commentary for laboratory practical scripts. Journal of Chemical Education, V.78, n. 12 p.1699-1703, 2001.

80. IBOPE. Disponível em:

<http://www.ibope.com.br/calandraWeb/servlet/CalandraRedirect?temp=5\&proj=PortalIBOP $\mathrm{E} \& \mathrm{pub}=\mathrm{T} \& \mathrm{db}=\mathrm{caldb} \& \mathrm{comp}=$ Internet $\&$ docid=FE850DB928FDE56A83256ECA00657ACD $>$. Acesso em 31 Out. 2005.

81. ORKUT. Disponível em: <http://www.orkut.com>. Acesso em 11/11/2005 
82. SLOCUM, L.E.; TOWNS, M.H.; ZIELINSKI, T.J. Online chemistry modules: interaction and effective faculty facilitation. Journal of Chemical Education, v.81, n.7, p.1058-1065, 2004

83. FENIXWEB. Disponível em:

<http://sistemas1.usp.br:8080/fenixweb/fexDisciplina?sgldis=SCE5811 >. Acesso em: 20 Out. 2005.

84. Annotated SPSS Output. Disponível em:

<http://www.ats.ucla.edu/stat/spss/output/factor1.htm>. Acesso em: 05 Out 2005.

85. Overview of Factor Analysis. Dispnível em: 〈http://www.stat-help.com/notes.html>. Acesso em: 21 Out. 2005.

86. LEE, J.-S., CHO, H., GAY, G., DAVIDSON, B., \& INGRAFFEA, A. technology acceptance and social networking in distance learning. Educational Technology \& Society, v. 6 , n. 2 , p. $50-61,2003$.

87. HAIR, J.F.; ANDERSON, R.E.; TATHAM, R.L.; BLACK, W.C. Multivariate data analysis. Upper Saddle River, NJ: Prentice-Hall. 1995. p. 745. 


\section{ANEXO A - Busca bibliográfica de Janeiro de 1995 a Julho de 2005}

1995

1. THOMSON, P.A.; JENKINS, J.J.; BUHLER, D.R. Teaching online data systems to graduate students of toxicology. Journal of Chemical Education, v. 72, n. 4, p. 324-326, 1995.

2. CARANDE, R.; HARKANYI, K. Using Internet to disseminate an expert system of chemical information resources. Journal of Chemical Education, v. 72, n. 9, p. 812-813, 1995.

1996

3. TISSUE, B.M. Applying hypermedia to chemical education. Journal of Chemical Education, v. 73, n. 1, p. 65-71, 1996.

4. MOUNTS, R.D. Chemistry on the Web. Journal of Chemical Education, v. 73, n. 1, p. 68-71, 1996.

5. HOLMES, C.O.; WARDEN, J.T. CIStudio: a worldwide Web-based, interactive chemical information course. Journal of Chemical Education, v. 73, n. 4, p. 325-331, 1996.

6. DARENSBOURG, M.Y. Simple techniques can give pleasurable results. Journal of Chemical Education, v.73, n.11, p.A273, 1996.

7. GARDNER, T. Chemistry and the Internet: I. a beginner's guide to the Internet . The Chemical Educator. v.1, n.1, 1996.

8. GARDNER, T. Chemistry on the Internet: III. net shopping for chemists . The Chemical Educator. v.1, n.3, 1996.

9. GARDNER, T. Chemistry on the Internet: IV. designing animated GIF images for chemistry WWW pages. The Chemical Educator. v.1, n.4, 1996.

10. GARDNER, T. Chemistry on the Internet: V. methods of interactive Web-based mathematics for chemistry. The Chemical Educator. v.1, n.5, 1996.

11. LEMASTER, C. A look back and ahead. The Chemical Educator. v.1, n.5, p.1-4, 1996.

12. GARDNER, T. Chemistry and the Internet VI: designing imagemaps for chemistry Web pages . The Chemical Educator. v.1, n.6, 1996.

13. GARDNER, T.G. Chemistry on the Internet: II. communicating chemical images over the Internet. The Chemical Educator. v.1 n.2, 1996. 
14. OOI, B.G. Application of commercial and Web-based software programs for DNA sequence analysis in undergraduate biochemistry laboratory. The Chemical Educator. v.10, n.3, p186-189, 1996.

15. BOCK, J.C.; FRYHLE, C.B.; WALDOW, D.A. CIRRUS: a chemistry Internet resource for research by undergraduate students. Journal of Chemical Education, v. 74, n. 4, p. 441$442,1997$.

16. DOUGHERTY, R.C. Grade/performance contracts, enhanced communication, cooperative learning and student performance in undergraduate organic chemistry. Journal of Chemical Education, v.74, n.6, p.722-726, 1997.

17. JUDD, C.S. News from on-line. Journal of Chemical Education, v.74, n.9, p.1028-1030, 1997.

18. MOORE, J.W. Fount of information, vanity press, or intellectual tool. Journal of Chemical Education, v.74, n.9, p.1021, 1997.

19. LUNDBERG, P. Educational NMR software. Journal of Chemical Education, v.74, n.12, p.1489-1490, 1997.

20. JUDD, C.S. News from online. Journal of Chemical Education, v.74, n.12, p.1394$1395,1997$.

21. GARDNER, T. Chemistry on the Internet VII: analyzing molecular geometry using MDL's chemscape chime. The Chemical Educator. v.2, n.1, 1997.

22. STOUT, R.; TOWNS, M.H.; SAUDER, D.; ZIELINSKI, T.J.; LONG, G. Online cooperative learning in physical chemistry. The Chemical Educator. v.2, n.1, p.1-21, 1997.

23. GARDNER, T. Chemistry on the Internet VIII: VSEPR bond angle tutorial pages using a chemscape chime script. The Chemical Educator. v.2, n.2, 1997.

24. LEMASTER, C. Scholarship, education, and the Internet. The Chemical Educator. v.2, n.3, p.1-3, 1997.

1998

25. HOLMES, J. Introducing JCE online. Journal of Chemical Education, v.75, n.1, p.126, 1998.

26. BROOKS, D.W.; LIU, D.; WALTER, L.J. Delivering a chemistry course over the internet. Journal of Chemical Education, v.75, n.1, p.123-125, 1998. 
27. HOLMES, J.L. the journal at JCE online. Journal of Chemical Education, v.75, n.2, p.246, 1998.

28. HOLMES, J.L. JCE index. Journal of Chemical Education, v.75, n.3, p.382, 1998.

29. JUDD, C.S. News from online. Journal of Chemical Education, v.75, n.3, p.281, 1998.

30. HOLMES, J.L. JCE online: journal supplements online. Journal of Chemical Education, v.75, n.4, p.510, 1998.

31. WINK D.J. Exploring the NSF education web sites. Journal of Chemical Education, v.75, n.4, p.405-406, 1998.

32. JUDD, C.S. News from online: photons and lasers. Journal of Chemical Education, v.75, n.5, p.526, 1998.

33. HOLMES, J.L. JCE Internet. Journal of Chemical Education, v.75, n.6, p.779-780, 1998.

34. LEÓN, D.; URIDIL, S.; MIRANDA, J. Structural analysis and modeling of proteins on the web: an investigation for biochemistry undergraduates. Journal of Chemical Education, v.75, n.6, p.731-734, 1998.

35. RIGEMAN, S.A. The convergent evolution of a chemistry project: using laboratory posters as a platform for web page construction. Journal of Chemical Education, v.75, n.6, p.727-730, 1998.

36. WINK, D.J. Award data searches at the NSF web site. Journal of Chemical Education, v.75, n.6, p.677-678, 1998.

37. HOLMES, J.L. JCE online. Journal of Chemical Education, v.75, n.7, p.926, 1998.

38. WINK, D.J. Science and engineering information at the NSF web site. Journal of Chemical Education, v.75, n.7, p.814, 1998.

39. WINK, D.J. Proposal preparation aids at the NSF web site. Journal of Chemical Education, v.75, n.8, p.955, 1998.

40. SMITH, S.G. From mainframes to the web: 1998 George C. Pimentel award, sponsored by union carbide corporation. Journal of Chemical Education, v.75, n.9, p.1080-1085, 1998.

41. JUDD, C.S. News from online: using the web for your courses. Journal of Chemical Education, v.75, n.9, p.1073, 1998. 
42. GREENBOWE, T.J.; BURKE , K. A. Collaborative distance education: the Iowa chemistry education alliance. Journal of Chemical Education, v.75, n.10, p.1308-1312, 1998.

43. NOGGLE, J.H.; DYBOWSKI, C.R. Using the World Wide Web in a course in physical chemistry. Journal of Chemical Education, v.75, n.11, p.1499, 1998.

44. WINK, D.J. Education, emerging information technology, and the NSF. Journal of Chemical Education, v.75, n.11, p.1370, 1998.

45. TOWNS, M.H.; KREKE, K.; SAUDER, D.; STOUT, R.; LONG, G.; ZIELINSKI, T.J. An assessment of a physical chemistry online activity. Journal of Chemical Education, v.75, n.12, p.1653-1657, 1998.

46. BENDER, J. Report on "the sophomore physical and inorganic courses". The Chemical Educator. v.3, n.1, p.1-11, 1998.

1999

47. HOLMES, J.L.; GETTYS, N.S. Prospectus 1999. Journal of Chemical Education, v.76, n.1, p.143-144, 1999.

48. WINK, D.J. systemic education reform: links from the NSF web site. Journal of Chemical Education, v.76, n.2, p.162, 1999.

49. JUDD, C.S. News from online: industrial chemicals and polymers. Journal of Chemical Education, v.76, n.2, p.152-153, 1999.

50. SWEETING, L.M. Ethics in science for undergraduate students. Journal of Chemical Education, v.76, n.3, p.369-372, 1999.

51. GAMMON, S.D.; HUTCHISON, S.G.; WALLER, B.E.; TOLBERT, R.W. The Idaho k-8 teacher networking project: using the internet to improve k-8 science instruction. Journal of Chemical Education, v.76, n.5, p.708-713, 1999.

52. PAULISSE, K.W.; POLIK, W.F. Use of WWW Discussion boards in chemistry education. Journal of Chemical Education, v.76, n.5, p.704-707, 1999.

53. GLASER, R.E.; POOLE, M.J. Organic chemistry online: building collaborative learning communities through electronic communication tools. Journal of Chemical Education, v.76, n.5, p.699-703, 1999.

54. HOLMES, J.L. Molecular modeling. Journal of Chemical Education, v.76, n.6, p.872, 1999.

55. WINK, D.J. The national science board on science education. Journal of Chemical Education, v.76, n.6, p.751, 1999. 
56. JUDD, C.S. News from online: a spectrum of color. Journal of Chemical Education, v.76, n.6, p.728, 1999.

57. CRAIG, P.A. A project-oriented biochemistry laboratory course. Journal of Chemical Education, v.76, n.8, p.1130-1135, 1999.

58. FETTEROLF, M.L.; GOLDSMITH, J.G. An interactive dry lab introduction to vibrational raman spectroscopy using carbon tetrachloride. Journal of Chemical Education, v.76, n.9, p.1276-1277, 1999.

59. JUDD, C.S News from online: more spectroscopy. Journal of Chemical Education, v.76, n.9, p.1177-1178, 1999.

60. HOLMES, J.L. Now that $i$ have it, what can i do with it?. Journal of Chemical Education, v.76, n.11, p.1599, 1999.

61. RICKER, A.S.; THOMPSON, R.Q. Teaching chemical information in a liberal arts curriculum. Journal of Chemical Education, v.76, n.11, p.1590-1593, 1999.

62. WINK, D.J. WebCASPAR: NSF's educational database engine. Journal of Chemical Education, v.76, n.11, p.1479, 1999.

63. HOLMES, J.L. There has to be a better way to.... Journal of Chemical Education, v.76, n.12, p.1735, 1999.

64. JUDD, C.S. News from online: the environment. Journal of Chemical Education, v.76, n.12, p.1608-1609, 1999.

65. HOLDER, G.N.; BREINER, S.J.; FARRAR, D.G.; GOODEN, D.M.; MCCLURE, L.L. Qualitative identification of an unknown pesticide using gc-ms and online resources. The Chemical Educator. v.4, n.6, p.221-225, 1999.

66. FOUST JR., R.D.; CRUICKSHANK,B.; STRINGER, M.; OLANDER, J. The benefits of using Web-Based enhancements in an environmental chemistry class. The Chemical Educator. v.4, n.3, p.108-111, 1999.

67. STAMM, K.M.; FERMANN, J.T.; WHELAN, T.; BROUDY, R.R.; BOTCH, B.; VINING, W.J. Designing interactive instructional software: students as educators. The Chemical Educator. v.4, n.1, p.19-22, 1999.

68. WINK, D.J.. NSF Web site links on instructional technology and education. Journal of Chemical Education, v.77, n.1, p.25, 2000.

69. HOLMES, J.L. Medium frustration. Journal of Chemical Education, v.77, n.1, p.134, 2000 . 
70. PENN, J.H.; NEDEFF, V.M.; GOZDZIK, G. Organic chemistry and the internet: a webbased approach to homework and testing using the WE_LEARN system. Journal of Chemical Education, v.77, n.2, p.227-231, 2000.

71. WINK, D.J. New guidelines for elementary, secondary, and informal education. Journal of Chemical Education, v.77, n.2, p.150-151, 2000.

72. WEINER, S.W.; CERPOVICZ, P.F.; DIXON, D.W.; HARDEN, D.B.; HOBBS, D.S.; GOSNELL, D.L. RasMol and Mage in the undergraduate biochemistry curriculum. Journal of Chemical Education, v.77, n.3, p.401-406, 2000.

73. JUDD, C.S. News from online: the power of the voice. Journal of Chemical Education, v.77, n.3, p.299-300, 2000.

74. MOORE, J.W. Maintaining intellectual infrastructure. Journal of Chemical Education, v.77, n.3, p.279, 2000.

75. HOLMES, J.L. Online resources for high school teachers--a clic away. Journal of Chemical Education, v.77, n.4, p.536, 2000.

76. WINK, D.J. NSF web site information on new and continuing programs in science education. Journal of Chemical Education, v.77, n.4, p.443, 2000.

77. LAHTI, P.M.; MOTYKA, E.J.; LANCASHIRE, R.J. Interactive visualization of infrared spectral data: synergy of computation, visualization, and experiment for learning spectroscopy. Journal of Chemical Education, v.77, n.5, p.649-653, 2000.

78. WINK, D.J. New guidelines for undergraduate and technological education at the NSF web site. Journal of Chemical Education, v.77, n.5, p.560, 2000.

79. PATTERSON, M.J. Developing an internet-based chemistry class. Journal of Chemical Education, v.77, n.5, p.554-555, 2000.

80. COLE, R. Chemistry, teaching, and WebCT. Journal of Chemical Education, v.77, n.7, p.824-825, 2000.

81. JUDD, C.S. News from online: learning communities. Journal of Chemical Education, v.77, n.7, p.808-809, 2000.

82. MILLER, G.J.; HEIDEMAN, S.A.; GREENBOWE, T.J. Introducing proper chemical hygiene and safety in the general chemistry curriculum. Journal of Chemical Education, v.77, n.9, p.1185-1187, 2000.

83. WHISNANT, D.M. General chemistry multimedia problems. Journal of Chemical Education, v.77, n.10, p.1375-1376, 2000. 
84. KOSTECKA, K.S. Atomic absorption spectroscopy of calcium in foodstuffs in nonscience-major courses. Journal of Chemical Education, v.77, n.10, p.1321-1323, 2000.

85. JUDD, C.S. News from online: kitchen chemistry. Journal of Chemical Education, v.77, n.10, p.1268-1270, 2000.

86. WINK, D.J. Information technology research and education at NSF. Journal of Chemical Education, v.77, n.11, p.1395, 2000.

87. WHITE III, H.B.; JOHNSTON, M.V.; PANAR, M. Senior seminar focusing on societal issues related to chemistry and biochemistry. Journal of Chemical Education, v.77, n.12, p.1590-1593, 2000.

88. ROBINSON, W.R. Design of an asynchronous Internet-based course for advanced placement chemistry teachers. The Chemical Educator. v.5, n.5, p.246-251, 2000.

2001

89. WINK, D.J. The revised NSF web site. Journal of Chemical Education, v.78, n.1, p.24-25, 2001.

90. COLEMAN, W.F. JCE webware mission statement. Journal of Chemical Education, v.78, n.2, p.272, 2001.

91. BARRY, L. News from online: criteria for an "outstanding" high school chemistry web site. Journal of Chemical Education, v.78, n.3, p.154-155, 2001.

92. TOWNS, M.; SAUDER, D.; WHISNANT, D.; ZIELINSKI, T.J. Physical chemistry on line: interinstitutional collaboration at a distance. Journal of Chemical Education, v.78, n.3, p.414-415, 2001.

93. GAMMON, S.D.; HUTCHISON, S.G. Using the internet to individualize laboratory questions. Journal of Chemical Education, v.78, n.3, p.412-413, 2001.

94. JOHNSON, A.W. Is online learning really education? Journal of Chemical Education, v.78, n.4, p.453, 2001.

95. HOLMES, J.L. WWW site links. Journal of Chemical Education, v.78, n.7, p.984, 2001.

96. DONOVAN, W.J.; NAKHLEH, M.B. Students' use of web-based tutorial materials and their understanding of chemistry concepts. Journal of Chemical Education, v.78, n.7, p.975980, 2001.

97. TSAI, C. A review and discussion of epistemological commitments, metacognition, and critical thinking with suggestions on their enhancement in internet-assisted chemistry

classrooms. Journal of Chemical Education, v.78, n.7, p.970-974, 2001. 
98. CASIDAY, R.E.; HOLTEN, D.; KRATHEN, R.; FREY, R.F. Blood-chemistry tutorials: teaching biological applications of general chemistry material. Journal of Chemical Education, v.78, n.9, p.1210-1215, 2001.

99. CRAMER, C.J.; KORMOS, B.L.; WINGET, P.; AUDETTE, V.M.; BEEBE, J.M.; BRAUER, C.S.; BURDICK, W.R.; COCHRAN, E.W.; EKLOV, B.L.; GIESE, T.J.; JUN, Y.; KESAVAN, L.S.D.; KINSINGER, C.R. A cooperative molecular modeling exercise--the hypersurface as classroom. Journal of Chemical Education, v.78, n.9, p.1202-1205, 2001.

100. CHASTEEN, T.G. News from online: teaching with chemical instrumentation on the Web. Journal of Chemical Education, v.78, n.9, p.1144-1148, 2001.

101. MUROV, S. Exploring chemistry resources on the Internet. Journal of Chemical Education, v.78, n.10, p.1429-1432, 2001.

102. JUDD, C.S. News from online: chemistry and art. Journal of Chemical Education, v.78, n.10, p.1322-1323, 2001.

103. CARPI, A. Improvements in undergraduate science education using web-based instructional modules: the natural science pages. Journal of Chemical Education, v.78, n.12, p.1709-1712, 2001.

104. HALL, R.W.; BUTLER, L.G.; MCGUIRE, S.Y.; MCGLYNN, S.P.; LYON, G.L.; REESE, R.L.; LIMBACH, P.A. Automated, Web-based, second-chance homework. Journal of Chemical Education, v.78, n.12, p.1704-1708, 2001.

105. OLIVIER, G.W.J.; HERSON, K.; SOSABOWSKI, M.H. WebMark--a fully automated method of submission, assessment, grading, and commentary for laboratory practical scripts. Journal of Chemical Education, v.78, n.12, p.1699-1703, 2001.

106. KOCH, J.; VAN DER SLUYS, W.G. Distributed access teaching assistant (DATA). Journal of Chemical Education, v.78, n.12, p.1696-1698, 2001.

107. PIENTA, N.J.; THORP, H.H.; PANOFF, R.M.; GOTWALS JR., R.R.; HIR, H.P. A Web-Based, calculator-skills tutorial and self-test for general chemistry students. The Chemical Educator. v.6, n.6, p.365-369, 2001.

108. GRUSHOW, A.; BRANDOLINI, A.J. NMR spectroscopy: learned and delivered on the internet. The Chemical Educator. v.6, n.5, p.311-312, 2001.

109. PAMPLIN, K.L.; REEVES, P.C. reinforcing isotope and atomic-weight concepts in general chemistry using Internet-based mass-spectral data.The Chemical Educator. v.6, n.2, p.112-113, 2001. 
110. HICKS, B.W. News from Online: WWW sites for biochemistry teachers. Journal of Chemical Education, v.79, n.5, p.536-538, 2002.

111. SMITH, P.M. Thinkwell's chemistry by Dean Harmon and Gordon Yee, with Tarek Sammakia. Journal of Chemical Education, v.79, n.7, p.807, 2002.

112. HANSON, R.M. What's in a name? Journal of Chemical Education, v.79, n.11, p.1380, 2002.

113. HANSON, R.M. The chemical name game. Journal of Chemical Education, v.79, n.11, p.1380, 2002.

114. HANSON, R.M. Mechanism-based kinetics simulator. Journal of Chemical Education, v.79, n.11, p.1379, 2002.

115. HANSON, R.M. Hückel determinant solver. Journal of Chemical Education, v.79, n.11, p.1379, 2002.

116. COLEMAN, W.F.; WILDMAN, R.J. WebWare for classroom, computer room, student's room. Journal of Chemical Education, v.79, n.11, p.1379, 2002.

117. GALLAGHER, G.J.; ADAMS, D.L. Introduction to the use of primary organic chemistry literature in an honors sophomore-level organic chemistry course. Journal of Chemical Education, v.79, n.11, p.1368-1371, 2002.

118. HANSON, R.M. Principal species and $\mathrm{pH}$ in acid-base solutions. Journal of Chemical Education, v.79, n.12, p.1486, 2002.

119. COLEMAN, W.F.; WILDMAN, R.J. Acid-base equilibria in aqueous solutions. Journal of Chemical Education, v.79, n.12, p.1486, 2002.

2003

120. JAMES, C.R.; MCCANN, M.P. Data acquisition and instrument control via a Web page using Linux. Journal of Chemical Education, v.80, n.2, p.221, 2003.

121. MOORE, J.F.; MCCANN, M.P. Linux and the chemist. Journal of Chemical Education, v.80, n.2, p.219-221, 2003.

122. COUNTERMAN, A.E.; THOMPSON, M.S.; CLEMMER, D.E. Identifying a protein by maldi-tof mass spectrometry: an experiment for the undergraduate laboratory. Journal of Chemical Education, v.80, n.2, p.177-180, 2003.

123. MOORE, J.W. Are textbooks dispensable? Journal of Chemical Education, v.80, n.4, p.359, 2003. 
124. STUEKER, O.; BRUNBERG, I.; BORKENT, H.; VAN ROOIJ, J.; FELS, G. Webbased interactive animation of organic reactions. Journal of Chemical Education, v.80, n.5, p.583, 2003.

125. BORKENT, H.; VAN ROOIJ, J.; STUEKER, O.; BRUNBERG, I.; FELS, G. Mol4D: A Web-based computational chemistry interface for educational purposes. Journal of Chemical Education, v.80, n.5, p.582-583, 2003.

126. BOSCHMANN, E. Teaching chemistry via distance education. Journal of Chemical Education, v.80, n.6, p.704-708, 2003.

127. KOEHLER, B.P.; ORVIS, J.N. Internet-based prelaboratory tutorials and computerbased probes in general chemistry. Journal of Chemical Education, v.80, n.6, p.606-608, 2003.

128. JOHNSTON, D.H. News from online: untangling the Web: the national digital libraries initiative. Journal of Chemical Education, v.80, n.7, p.733-734, 2003.

129. GRABOWSKI, J.J.; PRICE, M.L. Simple HTML templates for creating science oriented jeopardy! games for active learning. Journal of Chemical Education, v.80, n.8, p.967, 2003.

130. NAMEROFF, T. ChemTechLinks: alliances for chemical technician education. Journal of Chemical Education, v.80, n.8, p.993-994, 2003.

131. Constantinos E.E. SpecScan: a utility program for generating numerical data from printed forms of spectra or other signals. Journal of Chemical Education, v.80, n.9, p.10931094, 2003.

132. DORI, Y.J.; BARAK, M.; ADIR, N. A Web-based chemistry course as a means to foster freshmen learning. Journal of Chemical Education, v.80, n.9, p.1084-1092, 2003.

133. COLE, R.S.; TODD, J.B. Effects of Web-based multimedia homework with immediate rich feedback on student learning in general chemistry. Journal of Chemical Education, v.80, n.11, p.1338-1343, 2003.

134. CHARLESWORTH, P.; VICIAN, C. leveraging technology for chemical sciences education: an early assessment of webct usage in first-year chemistry courses. Journal of Chemical Education, v.80, n.11, p.1333-1337, 2003.

135. WAMSER, C.C. E-mail molecules-individualizing the large lecture class. Journal of Chemical Education, v.80, n.11, p.1267-1270, 2003.

136. BENEFIEL, C.; NEWTON, R.; CROUCH, G.J.; GRANT, K. Remote NMR data acquisition and processing in the organic chemistry curriculum. Journal of Chemical Education, v.80, n.12, p.1494-1496, 2003. 
137. SINEX, S.A.; GAGE, B.A. Discovery learning in general chemistry enhanced by dynamic and interactive computer visualization. The Chemical Educator. v.8, n.4, p.266$270,2003$.

138. VITZ, E. DigiDemos debut. Journal of Chemical Education, v.81, n.1, p.160, 2004.

139. JCE EDITORIAL STAFF Classroom, homework, quiz, and exam questions. Journal of Chemical Education, v.81, n.1, p.158, 2004.

140. ROBINSON, W.R. Cognitive theory and the design of multimedia instruction. Journal of Chemical Education, v.81, n.1, p.10-12, 2004.

141. PENCE, L.E. A chemical information assignment for nonscience majors. Journal of Chemical Education, v.81, n.5, p.764-768, 2004.

142. HARPP, D.N.; FENSTER, A.E.; SCHWARCZ, J.A.; ZORYCHTA, E.; GOODYER, N.; HSIAO, W.; PARENTE, J. Lecture retrieval via the Web: better than being there? Journal of Chemical Education, v.81, n.5, p.688-689, 2004.

143. SLUNT, K.M.; GIANCARLO, L.C. Student-centered learning: a comparison of two different methods of instruction. Journal of Chemical Education, v.81, n.7, p.985-988, 2004.

144. BARTHOLOW, M. Using chemistry comes alive! in the classroom. Journal of Chemical Education, v.81, n.7, p.951, 2004.

145. SHIVE, L.E.; BODZIN, A.M.; CATES, W.M. A national science standards-based study of Web-based inquiry in chemistry. Journal of Chemical Education, v.81, n.7, p.1066-1072, 2004.

146. HOLLAND, L.A.; TOMECHKO, S.; LEIGH, A.M.; OOMMEN, A.; BRADFORD, A.; BURNS, A.E. Real-time distance research with IP network videoconferencing: extending undergraduate research opportunities. Journal of Chemical Education, v.81, n.8, p.12241228, 2004.

147. KESSLER, J. Chemistry.org/kids. a great resource for elementary school science activities. Journal of Chemical Education, v.81, n.10, p.1398-1399, 2004.

148. LOVELAND, W. D.; GALLANT, A.; JOINER, C. The living textbook of nuclear chemistry: a peer-reviewed, Web-based, education resource. Journal of Chemical Education, v.81, n.11, p.1670-1671, 2004.

149. BARAN, J.; CURRIE, R.; KENNEPOHL, D. Remote instrumentation for the teaching laboratory. Journal of Chemical Education, v.81, n.12, p.1814-1816, 2004. 
150. CANCILLA, D.A. Initial design and development of an integrated laboratory network: a new approach for the use of instrumentation in the undergraduate curriculum. Journal of Chemical Education, v.81, n.12, p.1809-1813, 2004.

2005

151. VAN RYSWYK, H. Writing-intensive multimedia projects in the instrumental methods course. Journal of Chemical Education, v.82, n.1, p.70-72, 2005.

152. BARRIE, P.J. Javascript programs to calculate thermodynamic properties using cubic equations of state. Journal of Chemical Education, v.82, n.6, p.958-959, 2005.

153. PIENTA, N.J. Faculty Guide for moving teaching and learning to the Web, second edition (Judith V. Boettcher and Rita-Marie Conrad). Journal of Chemical Education, v.82, n.7, p.1000, 2005. 


\section{ANEXO B - Questionário de caracterização}

1. Onde você realizou o ensino médio:

( ) Na Rede privada

( ) Na Rede pública

( ) Parte na Rede privada e parte na rede pública

2. Tem acesso a algum microcomputador? ( ) Não ( ) Sim

3. Se sim, qual tipo? ( ) PC ( ) Macintosh

4. Onde você costuma utilizar mais freqüientemente o computador?

( ) Em Casa ( ) Na Universidade ( ) No trabalho ( ) Outro

5. Que sistema operacional está instalado?

( ) Windows ( ) MacOS ( ) Linux ( ) Outro

6. Possui acesso a Internet? ( ) Não ( ) Sim

7. Quanto tempo em média você utiliza a Internet por semana?

( )Menos de cinco horas

( )De cinco a dez horas

( )De dez a vinte horas

( )Mais de vinte horas

8. Que programa navegador você utiliza?

( ) Internet Explorer ( ) Netscape Navigator ( ) Opera ( ) Outro

9. Qual das afirmativas poderia traduzir melhor sua relação com a Internet?

( ) Não me sinto confortável ao utilizar

( ) Consigo apenas os resultados que necessito

( ) Quase sempre consigo mais do que esperava

( ) Sinto-me completamente confortável ao utilizar

10. Você acredita que a implantação de material suplementar para esta disciplina via Internet pode ajudar o seu desempenho? ( ) Não ( ) Sim

11. De que forma? Questão dissertativa. Livre.

12. Com que objetivos você utiliza a Internet?

( ) Busca de informações para resolução de exercícios e trabalhos

( ) E-mail

( ) Entretenimento

( ) Comunidades Virtuais 


\section{ANEXO C - Questionário de avaliação}

1. A utilização do website melhora a qualidade do curso que eu realizo.

2. A utilização do website me permite realizar tarefas do curso mais rapidamente.

3. A utilização do website torna mais fácil o estudo da matéria.

4. A utilização do website aumenta minha produtividade

5. A utilização do website aperfeiçoa minha eficácia nos trabalhos do curso.

6. Eu acho o website útil no andamento do curso.

7. O uso do website é fácil pra mim.

8. É fácil para eu aprender a usar o website e todas suas funcionalidades.

9. Eu acho o website fácil de usar.

10. Eu achei o website de fácil interação.

11. Minha interação com o website é simples e fácil.

12. Eu acho fácil obter a informação que eu quero pelo website.

13. Eu uso muito o website em minhas tarefas no curso.

14. Eu uso o website sempre que possível em minhas tarefas no curso.

15. Eu uso freqüentemente o website para realizar minhas tarefas no curso.

16. Eu uso o website nas tarefas do curso apenas quando acho apropriado.

17. O website me ensina conceitos que eu não vi em nenhum outro lugar.

18. O website clarifica conceitos que eram confusos pra mim.

19. O website torna mais claros conceitos apresentados nos livros.

20. O website torna mais claros conceitos ensinados em sala de aula.

21. O website fornece meios de referência acessíveis, de maneira mais fácil e a qualquer hora.

22. Eu gostei do website, espero que existam outros nas próximas disciplinas.

23. Eu aprendo melhor pela Internet porque posso revisar a matéria dada com maior facilidade.

24. Com base na sua utilização, sugira melhorias para o website. 


\section{ANEXO D - Verbetes inseridos no sítio}

\section{Algarismos Significativos}

\section{Exatidão}

Qualidade de exato. Absoluta justeza na determinação de medida, peso, valor etc.

\section{Incerteza}

Estado ou caráter do que é incerto. Falta de certeza; dúvida, hesitação, indecisão, imprecisão.

\section{Valor Aceito}

Corresponde à média (ou mediana) de resultados obtidos, quer por leitura direta, quer mediante cálculos. É o valor mais provável, em repetições de um dado processo metrológico.

\section{Valor de Referência}

Valor correspondente à substância padrão certificada.

\section{Erro}

Grandeza que se relaciona à qualidade analítica em termos de controle de erros sistemáticos. Associa-se o máximo desvio de valor individual, em relação ao valor de referência. Não tem duplo sinal e é avaliado pelo desvio máximo absoluto ou relativo, em relação ao valor aceito.

\section{Conformidade}

Atendimento a requisitos ou especificações.

\section{Tolerância}

Faixa de valores aceitáveis em processos químicos (Indústria de processamento).

\section{Rastreabilidade}

Garantia de exatidão do resultado de interesse, em relação ao valor aceito como referência.

\section{Análise Gravimétrica}

\section{Sinal Analítico}

Qualquer variação observável no estado de um sistema, seja uma variação de cor, volume, produção de gás, turbidez, etc.

\section{Teor}

Proporção, em um todo, de determinado componente.

\section{Contaminante}

Qualquer espécie que não seja a de interesse analítico.

\section{Estequiometria}

A palavra estequiometria deriva do grego "STOICHEON", que significa "a medida dos elementos químicos", ou seja, as quantidades envolvidas de cada substância em uma reação química. 


\section{Análise Volumétrica}

\section{Próton}

Íon Hidrônio ou Hidroxônio, nada mais que o hidrogênio ionizado aquoso, ou o cátion do solvente água.

\section{Eletrólito}

Substância que dissolvida em água torna-se condutora de corrente elétrica (é o caso, p.ex., de todos os sais inorgânicos que são compostos de eletrovalência).

\section{pH}

Representação da escala na qual uma solução neutra é igual a sete, os valores menores que sete indicam uma solução ácida e os maiores que sete indicam uma solução básica.

\section{Dissociação}

Ação ou efeito de dissociar(-se); Separação de uma molécula em dois ou mais fragmentos (átomos, íons, radicais) por reação com uma ou mais moléculas ou por absorção de radiações eletromagnéticas. 


\section{ANEXO E - Links inseridos no sítio}

\section{Algarismos Significativos}

1. UNTITLED document. Disponível em:

<http://www.cq.ufam.edu.br/cd_24_05/qu\%EDmica\%20moderna.htm>. Acesso em: 09 Nov. 2005.

2. ALFA010304. Disponível em: <http://allchemy.iq.usp.br/pub/metabolizando/alfa010304.ppt>. Acesso em: 09 Nov. 2005.

3. Disponível em: <http://www.csarmento.uminho.pt/docs/ncr/de_mecanica/2.PDF>. Acesso em: 09 Nov. 2005.

4. ERROS e medidas. Disponível em: <http://educar.sc.usp.br/fisica/erro.html>. Acesso em: 09 Nov. 2005.

5. ARTIGO1. Disponível em: 〈http://nautilus.fis.uc.pt/gazeta/revistas/26_4/artigo1.pdf>. Acesso em: 09 Nov. 2005.

6. 7SIGNIFICATIVOS. Disponível em:

<http://www.materiais.ufsc.br/Disciplinas/EMC5710/7significativos.pdf >. Acesso em: 09 Nov. 2005.

7. RADIOMETER Analytical Resource Centre - MeterLab - MeterLab Documentation.

Disponível em: <http://www.radiometer-analytical.com/all_resource_centre.asp?code $=112 \& s=$ go $>$. Acesso em: 09 Nov. 2005.

8. TRATAMENTO de dados. Disponível em:

<http://www.dq.fct.unl.pt/cadeiras/miai/download/Tratamento-de-dados-MIA2004.pdf >. Acesso em: 09 Nov. 2005.

9. VIÉSES e fatores de confusão. Disponível em:

<http://www.ceargs.org.br/port/aulas/novas/vieses.ppt>. Acesso em: 09 Nov. 2005.

\section{Análise Gravimétrica}

10. DICAS sobre papéis. Disponível em:

<http://www.vanet.com.br/nucleogravurars/DICAS\%20SOBRE\%20PAPEIS.htm>. Acesso em: 09 Nov. 2005.

11. ELETROQUÍMICA (refazer). Disponível em:

<http://educar.sc.usp.br/quimapoio/eletrolitos.html>. Acesso em: 09 Nov. 2005. 


\section{Análise Volumétrica}

12. TEORIA de Bronsted y Lowry. Disponível em:

<http://webs.ono.com/usr005/chemnew/bronsted.htm>. Acesso em: 09 Nov. 2005.

13. BAFÔMETROS baseados em células de combustível. Disponível em:

<http://www.chemkeys.com/bra/md/eddns_2/sdub_2/bbecdc_1/bbecdc_1.htm>. Acesso em: 09 Nov. 2005.

14. PH. Disponível em: <http://www.igm.ineti.pt/e-

Geo/BDs/lexico_hidro/lexico.aspx?Termo=pH>. Acesso em: 21 Ago. 2004.

15. ÁCIDOS e bases. Disponível em: <http://www.terravista.pt/meiapraia/1062/acbase2.html>. Acesso em: 21 Ago. 2004. 


\section{ANEXO F - Navegação individual de cada um dos 17 alunos selecionados}

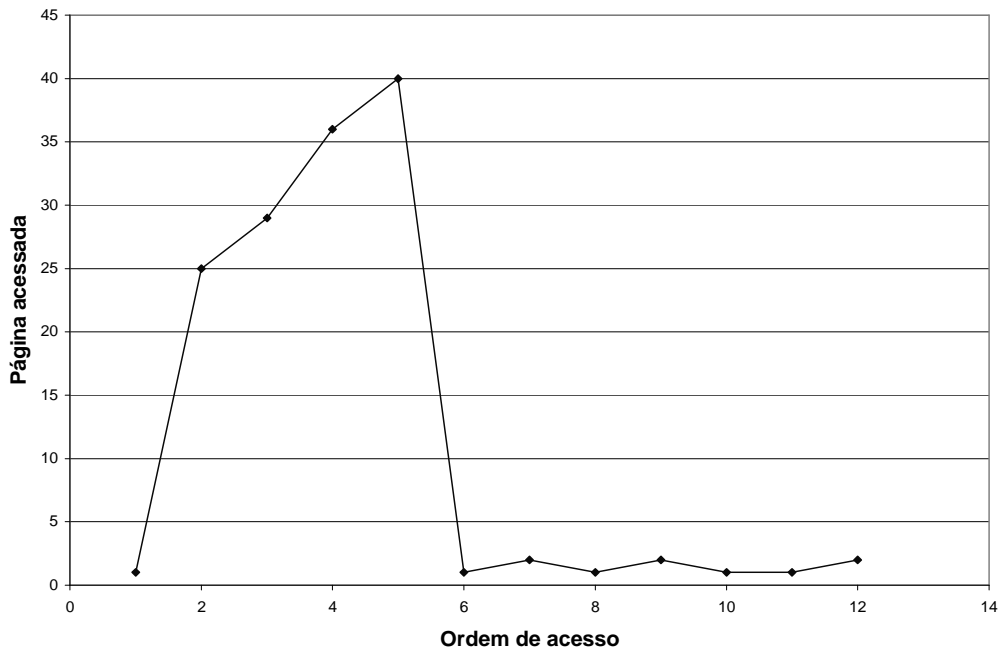

Aluno 1

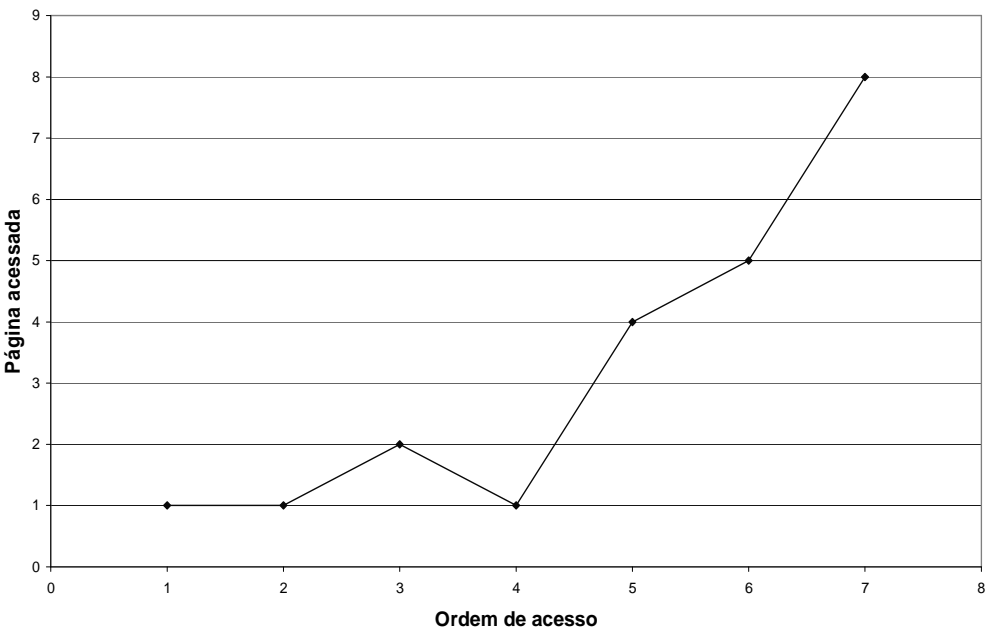

Aluno 2

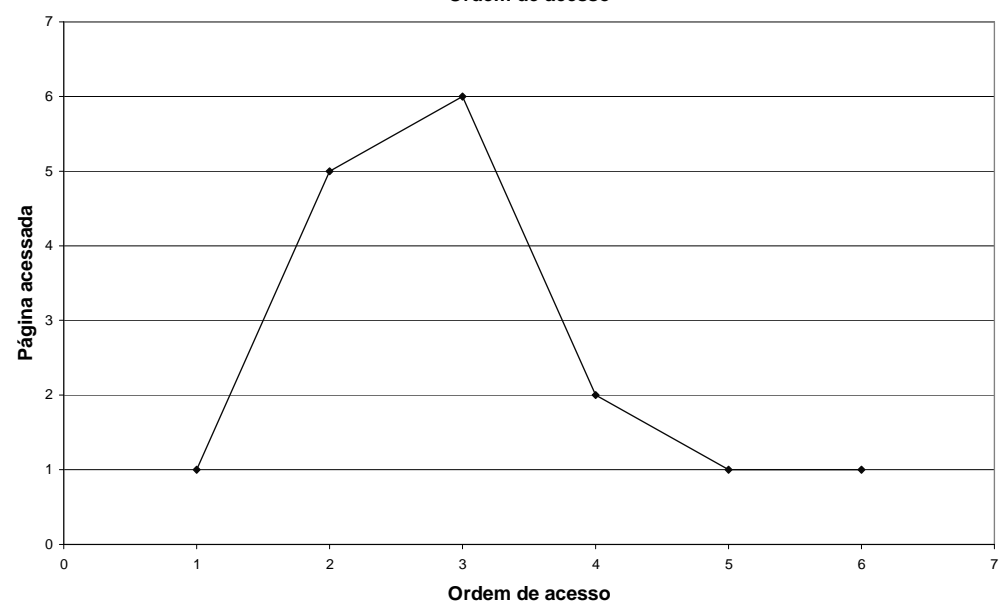

Aluno 3 


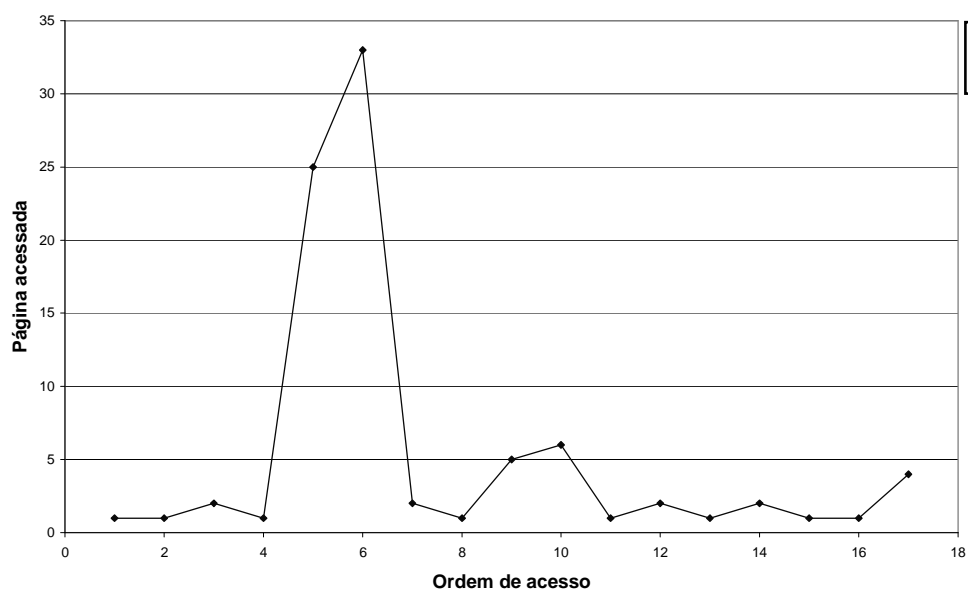

Aluno 4

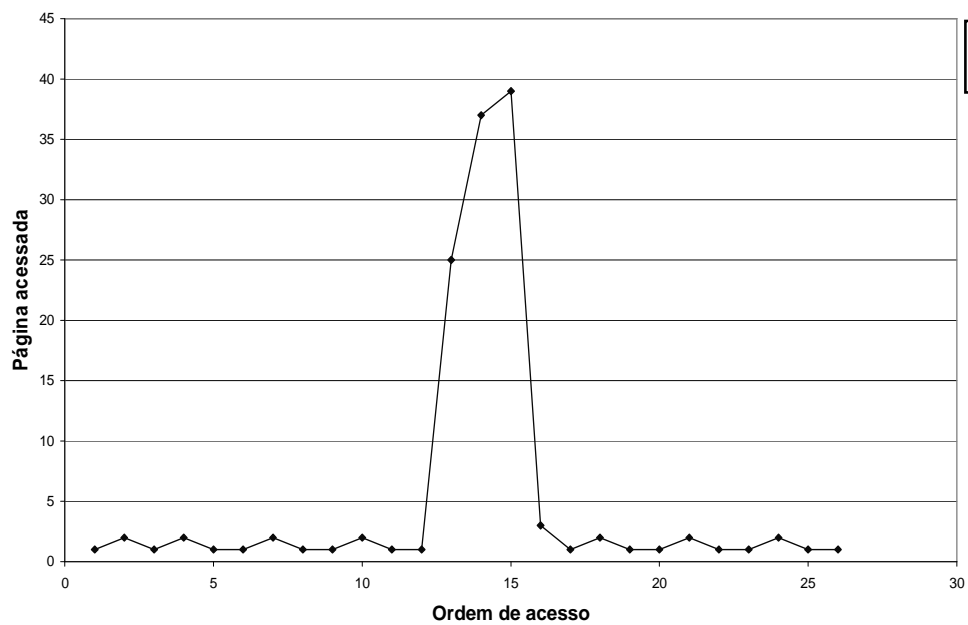

Aluno 5

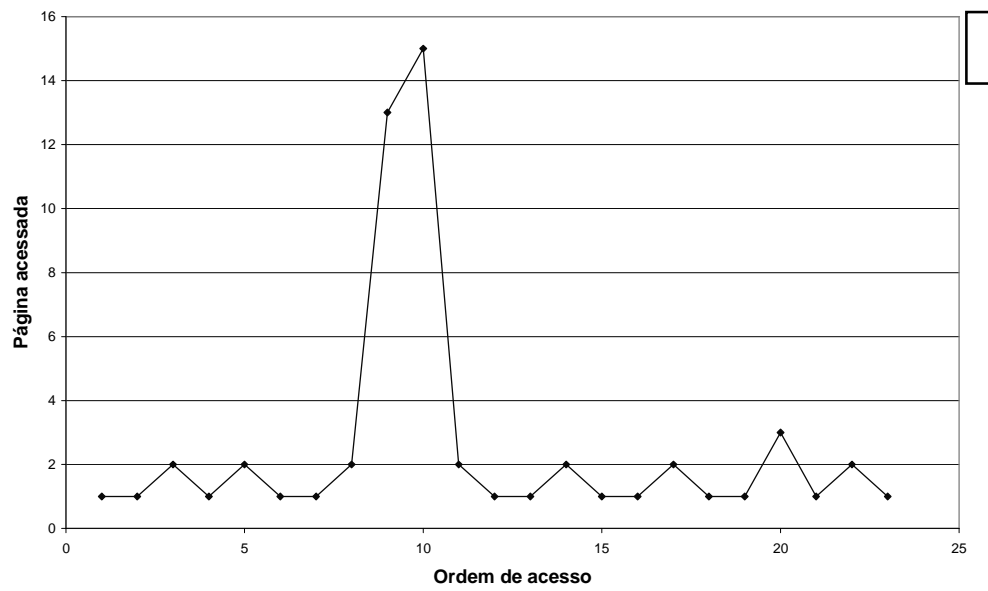

Aluno 6

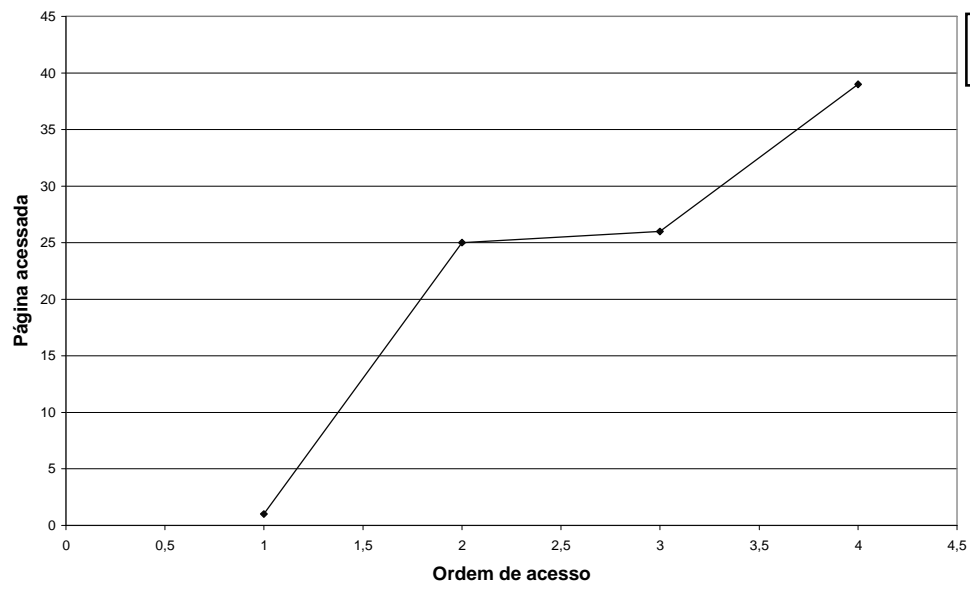

Aluno 7 


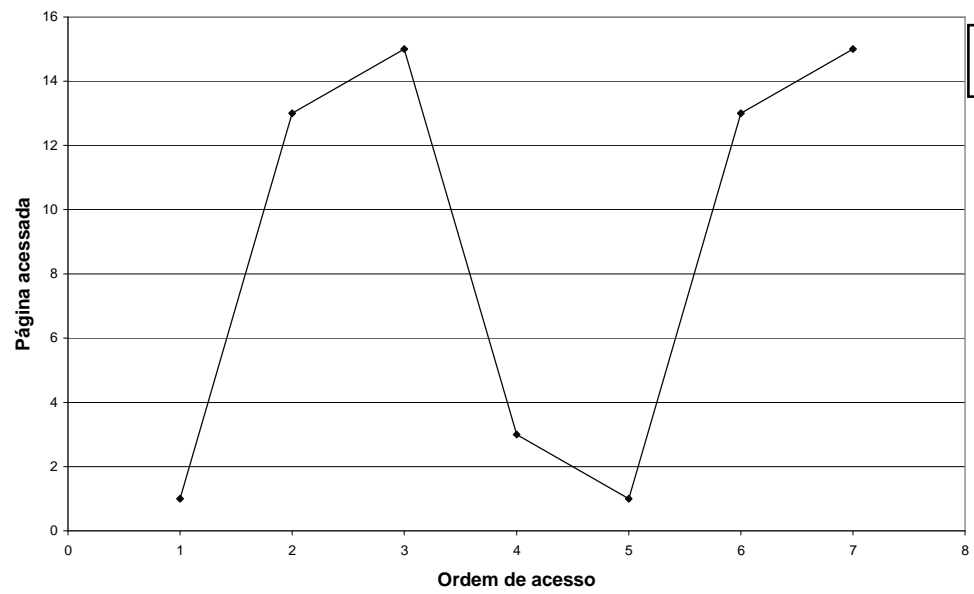

Aluno 8
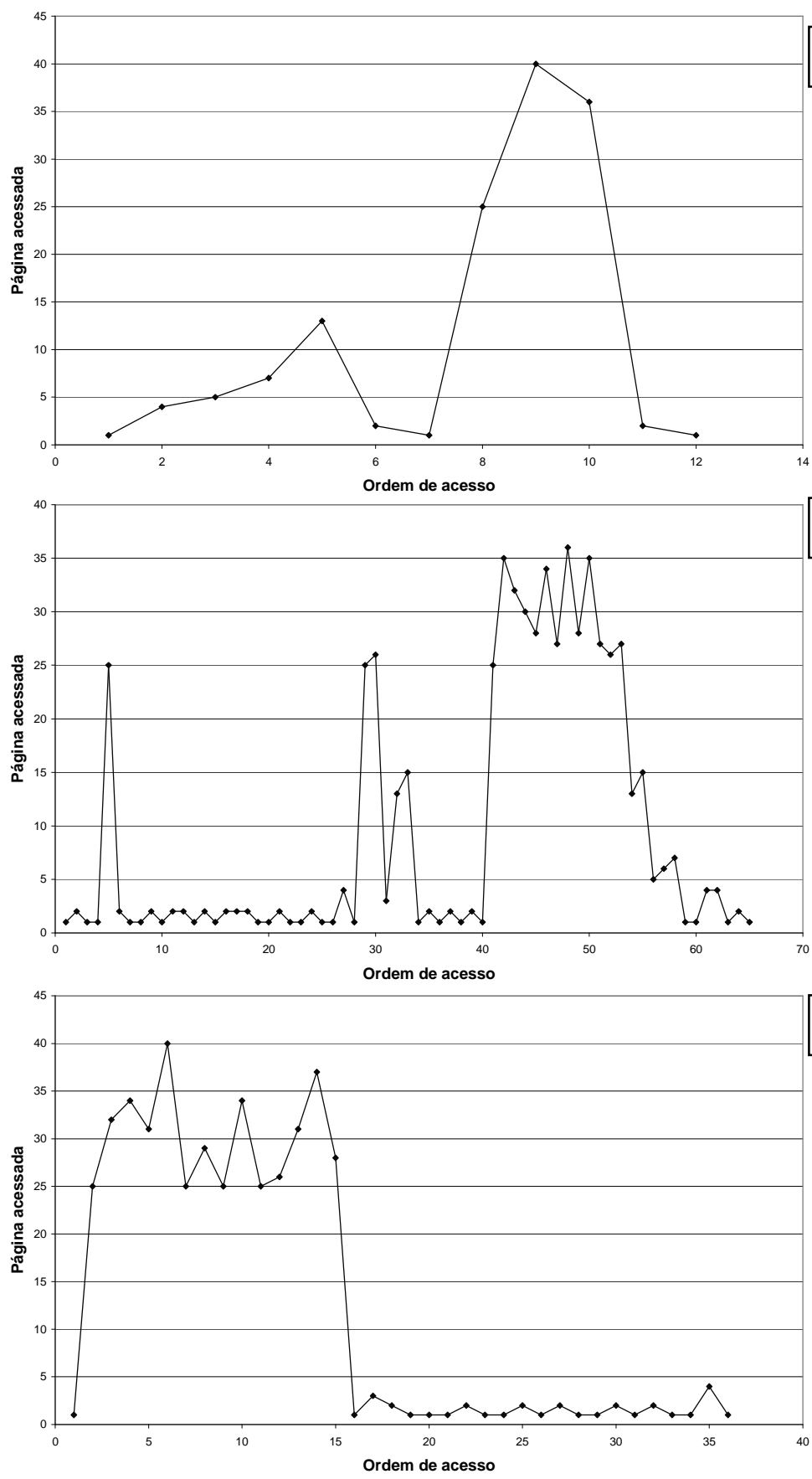

Aluno 9

Aluno 10

Aluno 11 


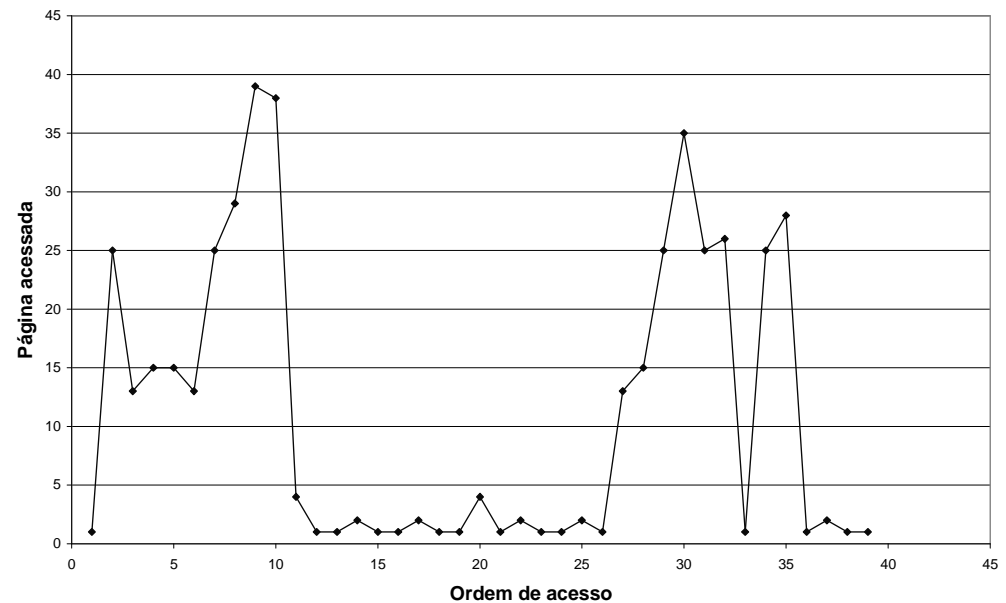

\section{Aluno 12}

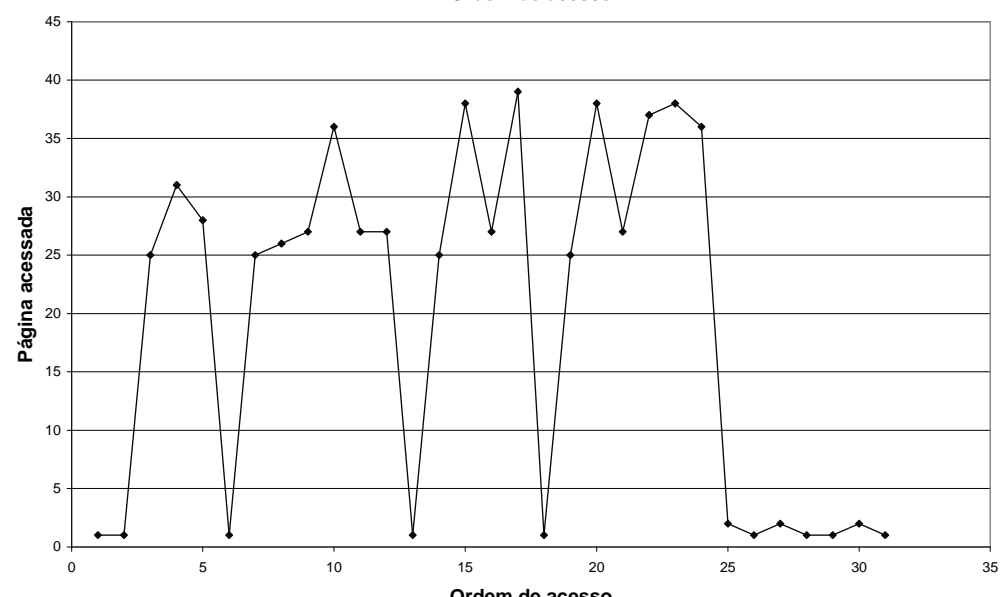

Aluno 13

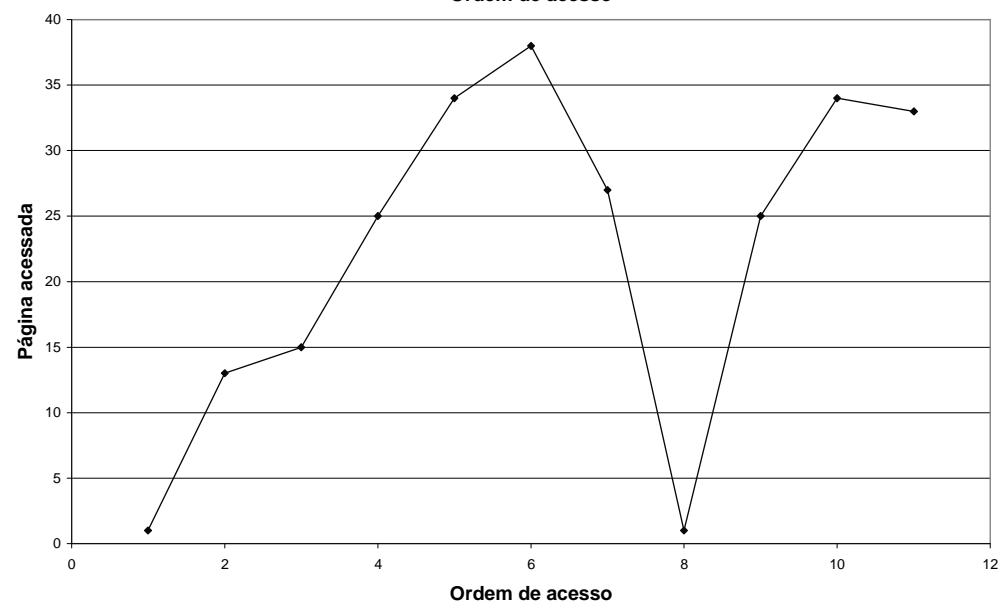

Aluno 14

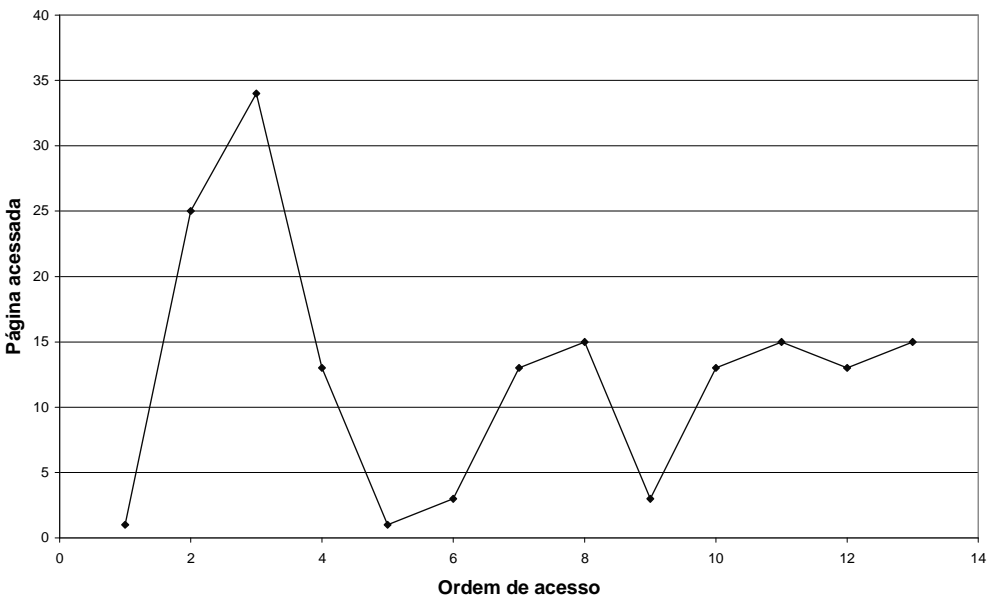

Aluno 15 


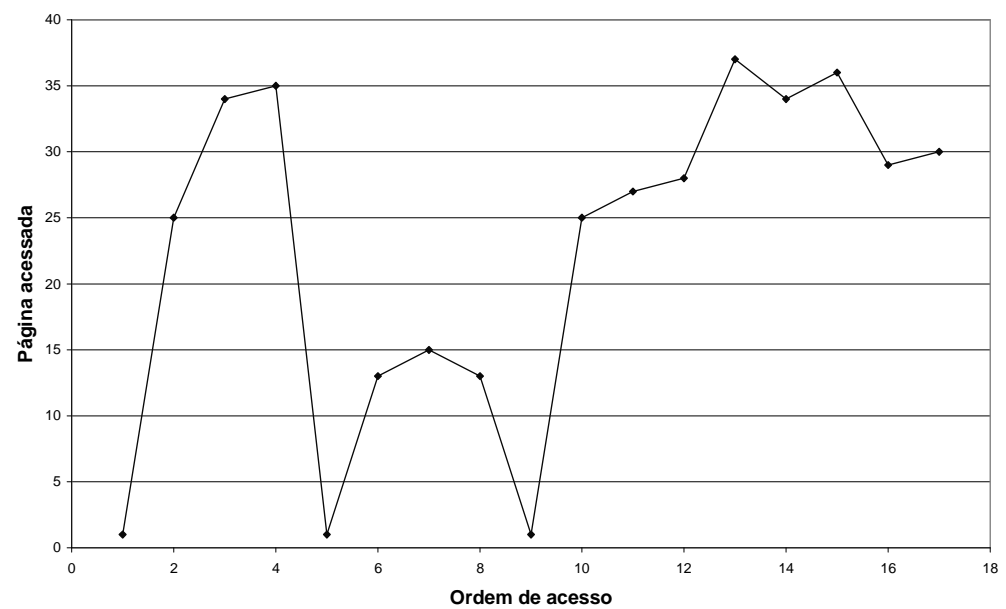

Aluno 16

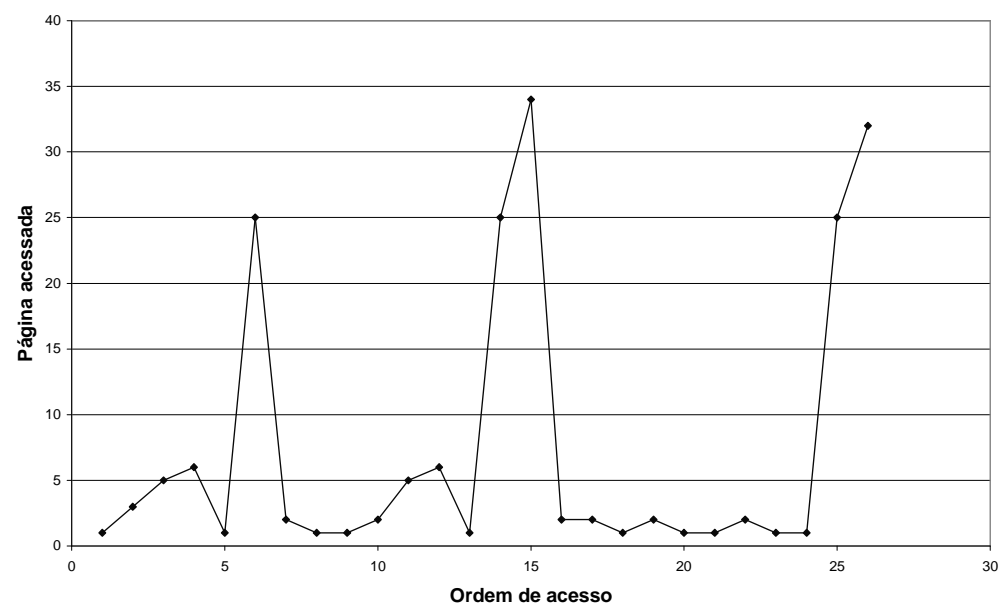

Aluno 17 